ANA LUIZA DE OLIVEIRA DUARTE FERREIRA

\title{
RAÍZES E PERFIS DA MODERNA AMÉRICA LATINA: ensaios sobre o homem, a cultura e as revoluções no Brasil e no México das primeiras décadas do século $\mathrm{XX}$, através dos clássicos ensaios de Sergio Buarque de Holanda e Samuel Ramos
}

v. 1.

Tese apresentada ao Programa de Pós-Graduação Interunidades em Integração da América Latina da Universidade de São Paulo para obtenção do título de Doutor

Área de Concentração: Comunicação e Cultura

Orientador: Prof. Dr. Wagner T. Iglecias

São Paulo 
À Juliana, cada vírgula e ponto bem colocado. $\mathrm{E}$ todas as ideias minimamente interessantes.

"Porque nuestras dos almas son como cielo y mar profundas e inconscientes en su grave callar; porque lloramos mucho y rezamos en vano, y porque nos devora un ansia pecadora, quiero decirte: ;Sufre!, quiero decirte: ;Llora!, quiero decirte: ¡Ama!, quiero decirte: ;Herman(a)!’” Salvador Novo, 1918-1920 


\section{AGRADECIMENTOS}

Agradeço ao professor Renato Queiroz, pelo interesse pelo meu projeto de Tese, que o levou a garantir meu ingresso no PROLAM-USP. E agradeço ao professor Wagner Tadeu Iglecias, pela confiança que o levou a seguir com a orientação de minha pesquisa, e pela solicitude crítica.

Agradeço às professoras Cremilda Medina, da ECA-USP e Gabriela Pellegrino Soares, da FFLCH-USP, pelas profícuas aulas por mim cursadas como aluna do PROLAM; inspiração para a Tese. E também pela participação em minha banca de qualificação (para a qual realizaram leitura minuciosa e crítica do texto que eu havia, até então, produzido), e pela presença na banca de defesa.

Com destaque, agradeço à morsista Beatriz Helena Domingues, minha orientadora de Mestrado, em História, na UFJF: pela grande consideração e por se fazer sempre presente, inclusive na defesa desta Tese. Agradeço, pois, ao professor Marcio Bobik Braga, que também integra a banca, e suplentes, pelo interesse.

Agradeço aos funcionários do PROLAM, Rodrigo Bronze e William Almeida, pela assessoria prestada todo tempo, em razão de minha particular inabilidade para cuidar de assuntos burocráticos. E à representante discente do Programa, Rita de Cássia Marques Lima de Castro, pela força e generosidade.

Agradeço ao PROLAM, na figura da diretora, professora Maria Cristina Cacciamali, especialmente pela concessão de ajuda de custo para minha curta expedição ao México: oportunidade na qual não apenas pude contatar estudiosos da obra de Samuel Ramos, e acessar fontes indispensáveis para o desenvolvimento de minha investigação, como conhecer in loco o outro dos dois universos que estudo.

Agradeço grandemente aos professores mexicanos, que tão bem me receberam: Victórico Muñoz (da UNAM - C.U.) e Gabriel Hernández Mendieta (da FES Acaltán). E aos cultos e generosos amigos, que tornaram minha estadia ainda mais proveitosa: Paula e Oscar Rosas, Victor Salazar Velazquez, Alonso Jimenéz.

Ademais, agradeço ao Consulado do México em São Paulo, pelo generoso empréstimo de livros. E ao professor José Ortiz Monasterio, do Instituto Mora, na Cidade do México, com quem tenho me correspondido, e que me tem estimulado a seguir estudando comparativamente os dois livros abordados nesta Tese.

Agradeço, nesse sentido, ainda, à Isabela Antunes, por ter carinhosamente me presenteado com um Raízes do Brasil, quando eu pronto ingressava na faculdade. Foi o 
primeiro livro que eu li, como futura historiadora, sem fazer a menor ideia de que a ele dedicaria tantos anos da minha vida.

Agradeço, também, à Juliana Ferreira e à Cristiane Pimentel, pelo cuidado com minhas solicitações e envios de rabiscos e versões preliminares dos capítulos completos; à Marina Furtado, que achou que o formato desta tese poderia e deveria ser mais bonito e mais ousado; ao Antonio Moraes, pela companhia às bibliotecas e mais; ao Alex Lopestos, pela contribuição “deja vu”; ao José A. dos Santos, pela assistência técnica.

Por fim, agradeço a meus pais Pedro e Lela, minhas irmãs Juliana e Berenice, e meus irmãos Pedro e Eduardo - apoio não apenas infraestrutural, como transcendente; à Carolina Gonzalez, à Kendy Piglialarme e à Cléo Guingo - pela liberdade do querer sem medida; às acolhidas de Sabrina Navarro, Daniela P. dos S., Elisa de Felippo, Daniel Barbosa, Daniela Tranches, Flavia Guimarães, Talita Mazza, Roberto Nogueira, Vitória Rodrigues, Thalita Dantes; e, é claro, cordialmente, ao grande Thales Leite. 


\section{RESUMO}

FERREIRA, Ana L. O. D. RAÍZES E PERFIS DA MODERNA AMÉRICA LATINA: ensaios sobre o homem, a cultura e as revoluções no Brasil e no México das primeiras décadas do século XX, através dos clássicos ensaios de Sergio Buarque de Holanda e Samuel Ramos Magaña. 2012. 298 f. Tese (Doutorado) - Programa de Pós-Graduação Interunidades em Integração da América Latina, Universidade de São Paulo, São Paulo, 2012.

O objetivo desta Tese é analisar como Sergio Buarque de Holanda e Samuel Ramos Magaña trabalharam a ideia de "revolução", e entenderam as possibilidades de uma revolução, respectivamente, no Brasil e no México, no início do século XX. Consideram-se, para tanto, os ensaios mais célebres desses dois autores: Raízes do Brasil e El perfil del hombre y la cultura en México, ambos publicados pela primeira vez na década de 1930, mas, como clássicos, tantas vezes lidos e ressignificados por distintas gerações. Partindo de um dos grandes expoentes da História Intelectual, Dominick LaCapra, demonstra-se que as metodologias ali trabalhadas indicam uma preocupação pontual com a crítica dos modos de pensar e ser do brasileiro e do mexicano contemporâneos, reais. Partindo de um dos grandes expoentes da História dos Conceitos, Reinhart Koselleck, considera-se o ambiente em que foram escritos Raízes e El perfil, e demonstra-se que (entre ensaístas e vanguardistas) se encontram num meio-termo, entre volteios críticos produzidos por não-especialistas, e interpretações metodologicamente mais acuradas, consolidadas anos depois.

Palavras-chave: História Intelectual, História dos Conceitos, História Contemporânea, História da América Latina. 


\begin{abstract}
FERREIRA, Ana L. O. D. ROOTS AND PROFILES OF MODERN LATIN AMERICA: essays about man, culture and revolutions in Brazil and Mexico in the early decades of the twentieth century, through classic Sergio Buarque de Holanda and Samuel Ramos Magaña essays. 2012. 298 f. Tese (Doutorado) - Programa de Pós-Graduação Interunidades em Integração da América Latina, Universidade de São Paulo, São Paulo, 2012.

The purpose of this thesis is to analyze how Sergio Buarque de Holanda and Samuel Ramos Magaña worked the idea of "revolution" and understood the possibilities of a revolution, respectively, in Brazil and Mexico, in the beginning of twentieth century. We consider, therefore, the most celebrated essays of these two authors: Raízes do Brasil and El perfil del hombre y la cultura en México, both first published in the 1930's, being classics often read and resignified by different generations. Considering one of the great exponents of Intellectual History, Dominick LaCapra, this Thesis demonstrates that the methodology used by Holanda and Ramos indicate a timely concern with criticism of the real ways of thinking and being of contemporary brazilians and mexicans. Considering one of the great exponents of the History of Concepts, Reinhart Koselleck, it also reckons (pointing similarities and distinctions about other essayists works, and also literary vanguard productions) how Raízes and El perfil are a middle ground between reviews produced by non-specialists and methodologically-accurate interpretations consolidated years later.
\end{abstract}

Keywords: Intellectual History, History of Concepts, Modern History, History of Latin America 


\section{RESUMEN}

FERREIRA, Ana L. O. D. RAÍCES Y PERFILES DE LA MODERNA AMERICA LATINA: ensayos sobre el hombre, la cultura y las revoluciones en Brasil y México de las primeras décadas del siglo $\mathrm{XX}$, por los clásicos ensayos de Sergio Buarque de Holanda y Samuel Ramos Magaña. 2012. 298 f. Tese (Doutorado) - Programa de PósGraduação Interunidades em Integração da América Latina, Universidade de São Paulo, São Paulo, 2012.

El objetivo de esta Tesis es analizar cómo Sergio Buarque de Holanda y Samuel Ramos Magaña trabajaron la idea "revolución", y comprendieron las posibilidades de una revolución, respectivamente, en Brasil y México, en el inicio del siglo XX. Son evaluados, entonces, los ensayos más célebres de eses dos autores: Raízes do Brasil y El perfil del hombre y la cultura en México, ambos publicados por primera vez en la década de 1930, pero, como clásicos, tantas veces leídos y resignificados por distintas generaciones. Partiendo de uno de los más grandes nombres de la Historia Intelectual, Dominick LaCapra, se demuestra que las metodologías allí trabajadas indican puntual preocupación con la crítica de los modos de pensar y ser del brasileño y del mexicano contemporáneos, reales. Partiendo de uno de los más grandes nombres de la Historia de los Conceptos, Reinhart Koselleck, se aborda el ambiente en lo cual fueron escritos Raízes y El perfil, y se demuestra que (entre ensayistas y vuarguarda literaria) se encuentran en un interregno, entre volteos críticos producidos por noespecialistas, e interpretaciones metodológicamente más cuidadas, consolidadas años después

Palabras-clave: Historia Intelectual, Historia de los Conceptos, Historia Contemporánea, Historia de Latino América. 


\section{SUMÁRIO}

\section{INTRODUÇÃO}

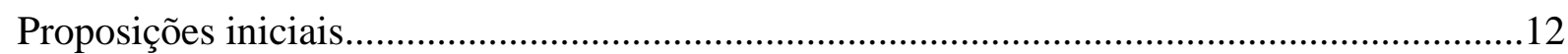

Algumas considerações teórico-metodológicas......................................................................12

Sobre dificuldades e as Partes que compõem esta Tese..........................................................19

CAPÍTULO 1: Apresentando autores, obras, e temas: considerações iniciais sobre Raízes do Brasil e El perfil del hombre y la cultura en México

1.1. Considerações iniciais sobre Holanda e seu Raízes............................................................22

1.2. Um conceito importante: o "homem cordial", na concepção de Holanda............................31

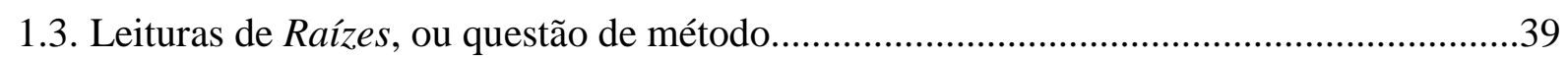

1.4. Considerações iniciais sobre Ramos e seu Perfil..............................................................4

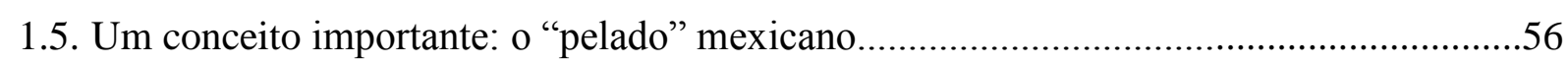

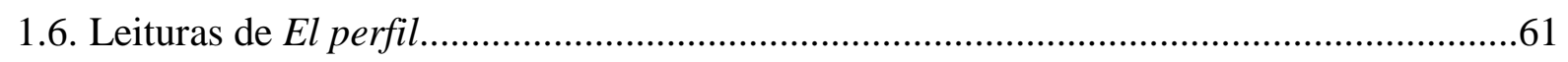

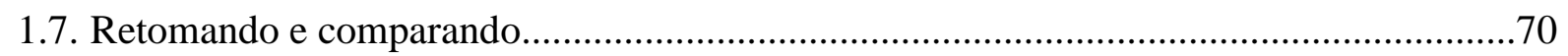

CAPÍTULO 2: Raízes e El perfil frente a outros autores e textos clássicos de princípios dos novecentos

2.1. A começar pelos ensaístas brasileiros..............................................................................

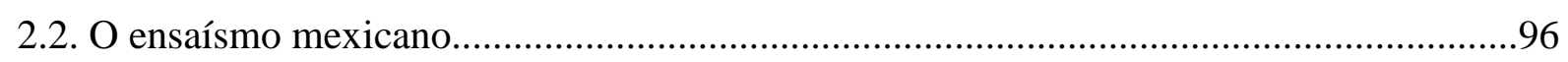

2.3. Retomando e comparando o lugar de Holanda e Ramos no ensaísmo brasileiro e mexicano das primeiras décadas do século XX................................................................117

2.4. O papel fundamental da vanguarda brasileira..............................................................122

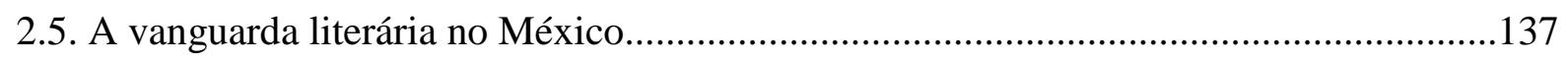

2.6. Retomando e comparando: sobre Holanda, Ramos, ensaístas e literatos vanguardistas

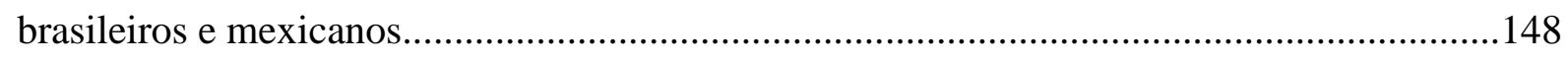

\section{CAPÍTULO 3: "Revolução" em Raízes, El perfil e em outros textos clássicos}

3.1. Considerações iniciais.............................................................................................153

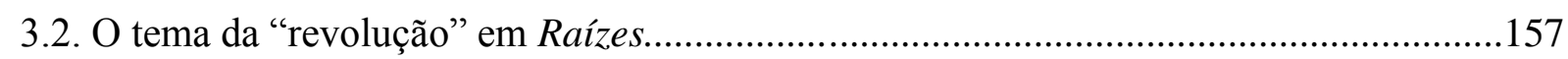

3.3. O tema da "revolução" em El perfil................................................................................161 
3.4. A "revolução" em outros textos da década de 1930, no Brasil e no México: debates cruzados.

\section{CAPÍTULO 4: O conceito de "revolução", e outros conceitos coevos}

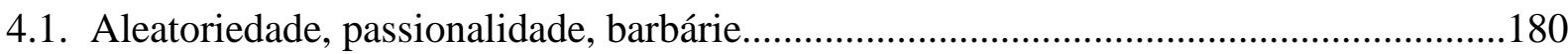

4.2. Pensar e estruturar intelectualmente a transformação sociopolítica...............................202

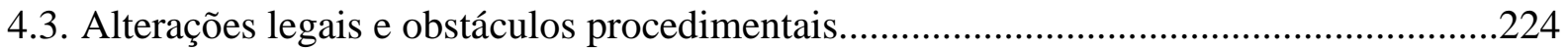

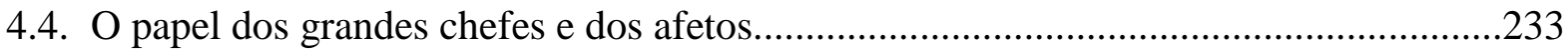

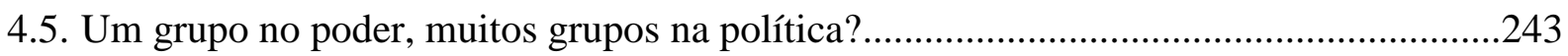

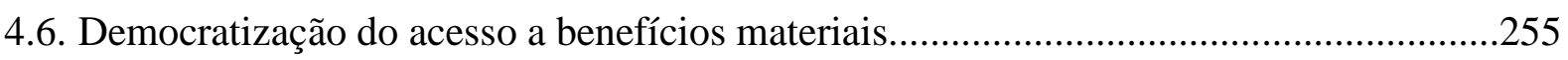

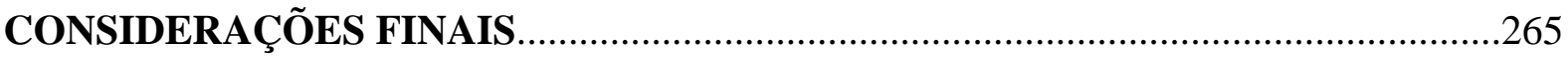

\section{BIBLIOGRAFIA}

Teoria e método. .267

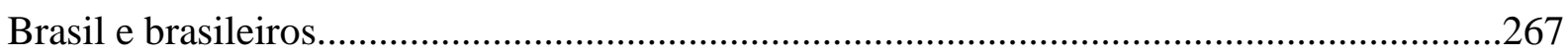

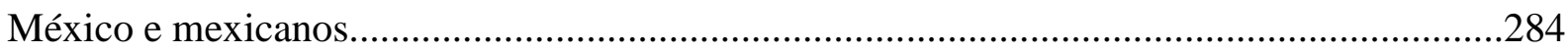




\section{INTRODUÇÃO}

\section{Proposições iniciais}

Esta Tese se insere nos campos historiográficos denominados "História Intelectual" e "História dos Conceitos". Dedica-se a cruzar a análise de dois textos clássicos, de maneira a promover entendimentos mais ricos a respeito das ideias propostas em um e outro. Como ambos os textos aqui selecionados foram produzidos por autores latinoamericanos, sobre cidadãos e nações da América Latina, pretende-se, em alguma medida, estabelecer reflexões sobre um sentido mais geral, de latinoamericanidade.

Os dois clássicos por mim escolhidos são Raízes do Brasil (1936), do brasileiro Sergio Buarque de Holanda, ${ }^{1}$ e El perfil del hombre y la cultura en México (1934), do filósofo mexicano Samuel Ramos Magaña.

O objetivo central desta Tese é refletir sobre que tipos de concepções tais obras elaboram, endossam, questionam ou replicam, no que diz respeito ao que se tem denominado "revolução", em seus respectivos países, e na América Latina. É estabelecer entendimentos acerca do que Holanda e Ramos pensaram, então, sobre o Brasil supostamente em processo de transformação revolucionária, e o México dito "revolucionário", no início do século XX. É buscar compreender como usaram o conceito de "revolução", especificamente naquelas e para aquelas conjunturas.

\section{Algumas considerações teórico-metodológicas}

O campo da História dos Conceitos foi definido, entre as décadas de 1970 e 1990, por Otto Brunner, Werner Conze e Reinhart Koselleck, a partir da organização de um célebre dicionário de ideias políticas. ${ }^{2}$ Em 1979 Koselleck, inspirado por tal experiência, publicou o livro Futuro passado: contribuição à semântica dos tempos históricos, que foi apenas recentemente lançado no Brasil, e cujas especulações me servem como referência.

A análise de Koselleck considera como relevantes para uma compreensão mais rica da historicidade dos conceitos alguns procedimentos: ele leva em conta a maneira como esses conceitos são tramados em determinadas obras, como eles são compartilhados por obras contemporâneas, e como remetem/configuram determinados fatos (KOSELLECK, p. 17).

\footnotetext{
${ }^{1}$ Assim como Pedro Meira Monteiro, opto por não acentuar o nome de Sergio Buarque de Holanda, embora muitos outros intérpretes o façam. O motivo aqui é o mesmo apontado na dissertação de mestrado de Monteiro: "essa é a forma como o próprio historiador autografava o nome" (MONTEIRO, 1999: 30).

${ }^{2} \mathrm{O}$ referido dicionário tinha como título Geschichtliche Grundbegriffe: Historisches Lexikon zur politischsozialen Sprache in Deutschland; em português: Conceitos básicos da História: Dicionário histórico do discurso político e social na Alemanha.
} 
Para Koselleck, afinal, conceitos não apenas são gerados por determinados fatores conjunturais, mas organizam versões sobre o social e o político.

Ao tomar como referência Koselleck, me afasto de abordagens propostas por outros autores que já investiram em estudos bem próximos ao meu; quais sejam: Claudia Wasserman, Silviano Santiago, e Everton Vieira Vargas. Está claro que a leitura desses outros pesquisadores foi fundamental para o desenvolvimento de minhas reflexões a respeito, e que me remeti a eles em diversos momentos de minha investigação; contudo, aqui, minha intenção analítica e metodológica é distinta.

Apresentou, pois, na sequencia, uma síntese dos trabalhos desses três autores, e então defino em que pontos, por partir de Koselleck, o presente trabalho deles se afasta.

$\mathrm{O}$ artigo Nacionalismo: origem e significado em Sergio Buarque de Holanda, Samuel Ramos e Ezequiel Martinez Estrada (2003), ${ }^{3}$ da professora da UFRGS, Claudia Wasserman se divide em duas seções. Uma primeira parte é dedicada à construção de uma síntese de aspectos econômicos, políticos, sociais e culturais que se têm como característicos do mundo e, em foco, da América Latina, nas primeiras décadas do século XX. Aí, a autora toma como referência os historiadores "britânicos" Eric Hobsbawn e Ernst Gellner, respectivamente nos livros Nações e nacionalismos desde 1880, e Nações e nacionalismo. Tal síntese compreende, note-se, mais da metade do artigo.

Uma segunda parte do texto de Wasserman trata mais propriamente das obras mencionadas no título: El perfil, Raízes, e uma terceira, La radiografia del pampa (1933), do argentino Ezequiel Martínez Estrada. A pesquisadora levanta, pois, algumas concepções que essas obras apresentariam, e as acompanha de extensas citações, compondo um quadro daquilo que considera o "significado" das ideias formuladas (WASSERMAN, p. 10-19). Nacionalismo: origem e significado pouco aborda, porém, da maneira como as concepções de Ramos e Holanda são propostas em seus clássicos ensaios, e dos conceitos que eles ali compuseram. Wasserman não chega a tratar nem mesmo dos "tipos", tão célebres, que, como veremos, esses autores ali apresentam.

A meu ver destarte tal autora negligencia dois vieses que Koselleck denota como essenciais na abordagem de obras clássicas, em seu Futuro passado - a composição dos conceitos, e seus usos -, para privilegiar a terceira - a abordagem das condições sociais que envolveram a escritura das referidas obras.

\footnotetext{
${ }^{3}$ Tal artigo foi elaborado a partir da tese defendida pela autora no ano de 1998, pela Universidade Federal do Rio de Janeiro, sob o título A questão nacional na América Latina do começo do século XX: Brasil, Argentina e México.
} 
Seguindo as proposições de Koselleck, eu concordaria que avaliar diversas versões e estudos acerca da conjuntura na qual clássicos são elaborados é fundamental, para que compreendamos com maior radicalidade seus conceitos, vocábulos, métodos empregados. Mas, por não abordar definições-chaves de El perfil e Raízes, e por não cruzá-las com definições trabalhadas por intelectuais mexicanos e brasileiros, seus contemporâneos, Wasserman avalia as "realidades históricas" brasileira e mexicana, de princípios dos novecentos, de uma maneira que Koselleck certamente classificaria como simplista.

É verdade que a pesquisadora declara a pretensão de apresentar intelectuais da época e daqueles países como importantes segmentos, por serem responsáveis por transformar o "repertório cultural de uma sociedade", por operarem a "construção de significados da nação e do nacionalismo" (WASSERMAN, p. 4-5). Porém, o que se depreende da leitura de Nacionalismo: origem e significado, pela divisão proposta - em uma parte na qual se sintetiza uma suposta "origem", e em outra na qual expõe um dado "significado" - é que conjunturas históricas dadas determinariam as obras e ideias nelas elaboradas.

Outro texto publicado no Brasil que se aproxima de minhas intenções, nesta Tese, é As raízes e o labirinto da América Latina (2006), do crítico literário brasileiro Silviano Santiago. Em comparação com a análise de Wasserman, esse segundo é, sob meu ponto de vista, consideravelmente mais interessante. Todavia, como o título da obra explicita, a comparação ali operada não é entre Holanda e Ramos, e sim entre Holanda e Octavio Paz, que publicou seu clássico El laberinto de la soledad, que foi publicado pela primeira vez em 1950; do que decorre, creio, algumas limitações.

Eu diria, citando Koselleck, que nessa comparação entre Raízes e El laberinto, de 1950, quer dizer, entre livros elaborados em conjunturas distintas, perde-se um tanto da chance de avaliar a "dimensão histórica e antropológica inerente a toda conceituidade" (KOSELLECK, p. 17). Perde-se um tanto a chance de avaliar a dimensão temporal, tão cara ao historiador, e por vezes, aí sim, dissolvem-se informações e avaliações em considerações essencialistas. Daí, eu diria que Santiago pouco contribui para se pensar os processos através dos quais demandas de leitura do passado e significações do passado podem se estruturar diferentemente, em cada tempo.

De maneira diversa, tomar em conta dois livros que foram construídos em momentos equivalentes, tal como faço nesta Tese, nos abre a duas perspectivas que considero relevantes para estudiosos interessados em uma reflexão crítica sobre a América Latina. Primeiramente, a possibilidade de, num recorte temporal específico, apresentar uma interpretação consistente sobre o papel intelectual de Ramos e Holanda, e o papel dos intelectuais em geral, no recorte 
espacial amplo da América Latina. Em segundo lugar, a possibilidade de, avaliando as diferenças entre eles, que viveram em uma mesma época, estruturar um estudo que dê conta da diversidade que caracteriza o continente latino-americano.

Curioso, a meu ver, então, que o historiador mexicano José Ortiz Monasterio, um dos poucos grandes conhecedores da obra de Holanda, no México, ${ }^{4}$ tenha insistido em explorar, num artigo recente, uma comparação entre Raízes e também, tal como Santiago, El laberinto; e não El perfil. $^{5}$

Quando por mim questionado, Ortiz concordou que as semelhanças entre Holanda e Ramos são mais evidentes, e que, portanto, se se pretende trabalhar por uma comparação entre intelectuais brasileiros e mexicanos, contrapor Raízes e El perfil poderia resultar mais profícuo: das evidências, se pode saltar às diferenças, e desdobrar reflexões mais articuladas e por isso mais ricas.

Ortiz justificou, então, que a preferência "viciada" por tomar El laberinto como fonte, lhe parece decorrer pura e simplesmente da maior fama de Paz. Sim, conforme o ponto de vista desse historiador mexicano, "su luz [de Paz] impide mirar mejor a otros autores como Ramos, cuya obra es igualmente fundamental".

Parafraseando o professor da Universidade de São Paulo Adalmir Leonídio, eu diria que:

o ato de escrever sobre os chamados 'ícones' do pensamento social [no Brasil, no México, no Ocidente] - aqueles que formam a 'elite' da 'hierarquia de relevância' - transformou-se numa demonstração de competência de quem soube escolher o que estudar e sobre quem escrever. Tal ato reafirma o prestígio dos 'ícones' na medida em que ratifica a sua importância como tema, criando assim um ciclo vicioso: por serem os mais estudados, os autores consagrados seriam reconhecidos como os notáveis representantes do pensamento social brasileiro. Ao contrário, os autores pouco citados são tidos como de pouca relevância. Pela posição que ocupam na 'hierarquia', tais autores não chegam a transmitir renome acadêmico àqueles que os elegem como tema de seus estudos (LEONÍDIO, p. 195).

Em outras palavras: mesmo Ramos sendo um clássico tem sido considerado, no México, um autor menor; e tem sido, no Brasil, desconsiderado. E é possível que, escapando ao comodismo das tendenciosas listas de "autores maiores", seu resgate, e, ainda, em

\footnotetext{
4 Ortiz é organizador de uma antologia de textos mais investigativos e também de crítica literária, do autor de Raízes, intitulada Sergio Buarque de Holanda: Historia, Literatura, Antologia (2007), e tem publicado diversos artigos sobre nosso célebre ensaísta, a começar por Raízes do Brasil de Sérgio Buarque de Holanda: un primer acercamiento (2002).

${ }^{5}$ Ortiz desconhece ao texto de Santiago, mas inúmeros pesquisadores brasileiros o têm tomado e desdobrado em estudos que replicam a comparação entre Raízes e El laberinto, ignorando (ou quase) o Perfil de Ramos; a exemplo: do professor de Estudos Literários da UFJF Evandro Nascimento; do cientista político, pesquisador do LCP-UFF, Marcelo Neder Cerqueira, e da professora de Letras da UFF Angela Maria Dias.
} 
comparação com Holanda, nos permita, afinal, rever seu valor e atribuir maior importância a seu Perfil.

A respeito do campo da História Intelectual, tangente ao da História dos Conceitos, considero como indispensável um texto do historiador norte-americano Dominick LaCapra; texto publicado no início da década de 1980, como capítulo do livro History and teory, e recentemente lançado na América Latina, por iniciativa do professor argentino Elias José Palti.

Nesse texto, LaCapra defende que "la Historia Intelectual no debería verse como una mera función de la Historia Social. Tiene que explorar otras cuestiones, que exigen técnicas diferentes" (LACAPRA, p. 239). Para ele, tais questões se relacionam ao fato de que nos textos clássicos "el uso del lenguaje se explora de una manera especialmente enérgica y crítica, que nos compromete como intérpretes en una conversación particularmente atrapante con el pasado" (Idem, p. 242).

LaCapra, assim, tal como Koselleck, critica interpretações segundo as quais textos são apresentados como meros reflexos de práticas sociais, autônomas e determinantes (Idem, p. 259-260). E sugere que, estudando clássicos e as conjunturas nas quais eles foram produzidos, os historiadores considerem duas dimensões. Primeiro, como as versões sobre a época estudada vêm sendo construídas, criticadas, valoradas, alteradas, sedimentadas, e como esses clássicos se inserem nesse processo de elaborações de entendimentos sobre a época. Segundo, como noções formuladas em tal período, tais como aquelas propostas nos clássicos objetos de análise, foram lidas e relidas à luz de demandas distintas, no decorrer dos anos que se passaram, agregando a eles, sempre, novos significados.

Ora, é escassa, nas interpretações de Wasserman e Santiago - assim como em outros autores que comparam clássicos brasileiros e mexicanos - a historicização das críticas apresentadas por célebres intérpretes. Quanto a mim, por serem essenciais, serão trabalhadas logo no primeiro Capítulo desta Tese.

Bom lembrar, então, a Tese do Programa de Sociologia da Universidade de Brasília, realizada pelo diplomata Everton Vieira Vargas, $O$ legado do discurso: brasilidade $e$ hispanidade no pensamento social brasileiro e latino-americano (2007). Vargas ali apresentou suas reflexões divididas em três seções principais: uma primeira dedicada a dois autores brasileiros, Holanda e Freire, e inúmeros ensaios por eles publicados; uma segunda na qual discorre sobre interpretações mais comuns de diversos textos escritos por vários intelectuais mexicanos, de gerações distintas, dentre os quais Ramos; e uma terceira, na qual cruza as perspectivas de todos eles, a respeito do Brasil, do México e da América Latina. 
Acredito que ser importantíssima a contribuição de Vargas, nesse momento, em que ainda são um tanto raros os livros editados no Brasil, sobre a intelectualidade mexicana. A iniciativa comparativa de Vargas também deve ser brindada, por serem também pouco comuns, em nosso país, as obras publicadas, nas quais constam contrastes entre a produção intelectual brasileira e a produção intelectual de outros países latinoamericanos, nas primeiras décadas do século XX.

Entretanto, se Vargas apresenta uma visão mais complexa sobre ensaios escritos por Holanda e Freire, apresenta, ainda, um quadro bastante vago sobre os mexicanos; um quadro no qual prevalecem reflexões sobre as interpretações clássicas acerca das grandes obras interpretativas do México, e não especificamente leituras dessas obras, desses textos, que viabilizaria uma substantiva crítica dessas interpretações clássicas.

Algo parecido, ainda que distinto, ocorre na já mencionada análise de Ortiz. No início de seu dito artigo ele aventa o risco de, em apreciações que consideram comparativamente duas ou mais obras, concedermos um maior número de páginas a uma ou outra. Não que ele, em verdade, o faça, mas fato é que o tratamento que propõe, então, a Holanda e Raízes, é bastante mais complexo do que aquele que propõe a Paz e El laberinto. Procedendo de maneira inversa à de Vargas, Ortiz se restringe, no caso de El laberinto, a descrever com minúcias a obra, esquecendo-se dos autores com os quais Paz dialogava, ou que dialogaram, posteriormente, com Paz.

Além do mais, por dividir o texto em duas partes, as semelhanças e diferenças entre uma e outra seção - afinal, o que configura uma interpretação comparativa - ficam um tanto soltas no artigo de Ortiz.

Nesse sentido, me parece importante destacar que Wasserman, Santiago e Vargas aqui Ortiz é exceção simplesmente porque não trabalha Ramos — insistem focar, das fontes selecionadas, suas contribuições para a conformação de uma identidade nacional, brasileira, mexicana; ou subcontinental, latinoamericana. Eis o que propõe toda uma tradição, no Brasil, de intérpretes das proposições de Holanda; e toda uma tradição, no México, de abordagem do legado de Ramos.

Há estudiosos, contudo, que vêm considerando como propostas centrais desses clássicos não a elaboração ou mesmo a análise das identidades, e sim o entendimento acerca da realidade específica, do Brasil, do México, da América Latina, na modernidade.

Um bom exemplo, nesse sentido, é Luiz Guilherme Piva, que propõe que, embora grande parte dos críticos do pensamento brasileiro das décadas de 1920 e 1930 tomem notas sobre o que se propunha, à época, a respeito da "nação" brasileira, conviria compreender 
também (ou mesmo sobretudo) o que naquele momento os ditos autores entendiam como possibilidade de "modernização", para o Brasil (PIVA, 2000, p. 86). Ou seja: ao invés de seguir a tendência de se buscar compreender como os intelectuais daquele período contribuíram para a formulação de versões identitárias, Piva busca compreender como aqueles intelectuais se lançavam à tarefa de pensar percursos e possibilidades de modernizar, no território específico de suas nações.

Conforme meu entendimento, assim, embora especialmente Raízes e El perfil tenham servido como base a partir da qual se estabeleceu identificação, ou se elaboraram discursos de identificação, no Brasil e no México, esse pode não ter sido inclusive o objetivo principal de Holanda e Ramos.

A meu ver, em verdade, Holanda não pretendia definir um brasileiro, e Ramos não pretendia definir um mexicano: eles estavam à procura de problematizar as versões mais correntes, de filigranar as percepções mais óbvias, e de estabelecer alguma base de crítica de entendimento sobre perfis e raízes do homem e da cultura brasileiros, mexicanos, latinoamericanos, na contemporaneidade. Eles pretendiam, dessa forma, avaliar possibilidade de efetivas transformações em seus países, de transformações autênticas, de transformações "revolucionárias".

Diferentemente de Wasserman, Santiago e Vargas, minha proposta nesta Tese fica sendo, afinal, explorar versões sobre as experiências sociopolíticas e culturais brasileiras e mexicanas, no período em que Ramos e Holanda ainda eram jovens intelectuais, e estavam escrevendo El perfil e Raízes. E, daí, perceber como tais livros se inserem na tradição de elaboração de sentidos para o conceito de "revolução", no Brasil, no México, na América Latina.

Sobretudo, enfim, o leitor deverá ter em mente que, em todos os Capítulos exploro, na escrita de Raízes e El perfil, três tensões que se repetem, invariavelmente, e que considero bases, nas concepções de Holanda e Ramos sobre as possibilidades e as experiências revolucionárias no Brasil e no México de princípios dos novecentos. Essas tensões são: entre o nacional e o estrangeiro, entre o tradicional e o moderno, entre a teoria e a prática.

Em outras palavras, o leitor deve ter em mente que a visão que os referidos autores apresentam, nas referidas obras, sobre a revolução brasileira e a revolução mexicana passa por estas três questões principais, que permeiam toda a escrita dos ditos clássicos, e que aparecem a todo o momento, nesta Tese: o fato de nós, latinoamericanos, sermos únicos, e ao mesmo tempo herdeiros de civilizações distantes, estrangeiras; de alcançarmos certo desenvolvimento, e ao mesmo tempo sermos considerados atrasados, arcaicos e incorrigíveis; 
e de que consideramos nossas características e procederes como "impróprios", quando, de repente, deveríamos considerá-los tão somente "próprios".

\section{Sobre dificuldades e os Capítulos que compõem esta Tese}

A análise de textos clássicos, como sugere LaCapra, traz consigo uma série de problemas; e digo "problemas" não apenas no sentido de "dificuldades", mas, mais propriamente, de "questões" a serem trabalhadas. A leitura dos clássicos se faz em camadas diversas, densas, e tais camadas estão não sobrepostas, acomodadas em seus lugares, e sim entrecruzadas, flutuantes.

LaCapra sugere a respeito de clássicos podemos considerar: conceitos que trabalham, conexões entre clássicos e outros textos sobre o momento sócio-histórico em que foram produzidos, conexões entre eles e textos sobre o universo mental/intelectual em que foram produzidos, conexões entre eles a biografia daqueles que os produziram, conexões com os demais textos produzidos por seus autores, e conexões com as diversas interpretações tecidas, a respeito deles, pelas mais diversas gerações de críticos, conexões com demandas intelectuais de outras conjunturas, que as interpretaram; etc (LACAPRA: 252).

Ora, todo estudo comparado de História Intelectual ganha algumas notas ainda mais graves, que o complexificam: em seu processo devemos dar conta de nos informarmos criticamente acerca de duas nações/comunidades distintas, que possuem trajetórias e conformações econômicas, sociais, políticas e culturais próprias; de duas conjunturas diferentes, cada qual com sua densidade e heterogeneidade características; e de dois intelectuais, que viveram experiências de vida ímpares.

Eis uma investigação, uma análise que equivale, portanto, a duas, que são tão somente pano de fundo para uma terceira, que é, em si, a análise fundamental: a comparação.

Como dar conta de todo conhecimento que tais estudos demandam? Como fazê-lo, de maneira crítica? Como lograr, ademais, não deixar alguns dos fios soltos, e compor um sentido, uma direção, uma estrutura coerente? De que maneira proceder, para que não nos restrinjamos ao mero exercício argumentativo, e possamos apresentar conhecimento histórico relativamente preciso, e reflexão de interesse público?

Nesta Tese, estruturamente, optei por dividir minhas argumentações em quatro capítulos. Em um primeiro, apresento esquematicamente meus objetos e as principais leituras feitas a respeito deles: traço uma breve biografia de Holanda e Ramos, e percurso intelectual de ambos até escreverem, respectivamente, Raízes e El perfil; apresento os conceitos mais 
célebres, elaborados nesses textos; e dialogo com autores que avaliaram não apenas a procedência dos conceitos formulados, como as metodologias ali construídas.

Nesse primeiro Capítulo, dividido em sete seções, - convém destacar - apresento reflexões basicamente introdutórias, que serão retomadas e discutidas adiante.

Em um segundo Capítulo, localizo Raízes e El perfil no momento em que foram publicados pela primeira vez. Busco compreender quais as relações entre Holanda e Ramos com os intelectuais mais reputados do período em que estavam redigindo esses textos; quais os temas gerais compartilhados; quais os critérios de rigor e de verdade em voga; quais os interesses políticos poderiam estar informando. Tanto no caso brasileiro como no caso mexicano, considero como expressivos - para o Brasil e México da época, mas também especificamente para Holanda e Ramos - trabalhos de ensaístas e autores ligados às vanguardas literárias.

Após trabalhar essas duas dimensões fundamentais, atenho-me ao conceito chave desta Tese: o conceito de "revolução". O terceiro Capítulo desta Tese, portanto, se dedica a discutir sobre os usos da palavra por Holanda e por Ramos, assim como por alguns de seus contemporâneos.

O quarto capítulo é dedicado a explorar outras noções que permeiam as visões de Holanda e Ramos sobre a "revolução", em seus países: (1) a ideia de revolução como processo irracional; (2) as ideias de revolução; (3) revolução e legalidade; (4) revolução e personalidade; (5) revolução e democratização política; (6) revolução e benefícios materiais.

No primeiro, segundo e terceiro Capítulos trabalho separadamente: Holanda, Raízes, e universo intelectual brasileiro das décadas de 1900 a 1930, e, depois, Ramos, El perfil e universo intelectual brasileiro das décadas de 1900 a 1930. Hora ou outra atento para alguns paralelos; mas apenas ao final retomo questões, e comparo. A ideia é ser o mais clara possível a respeito das especificidades de cada um desses clássicos, para que não se dissolvam completamente, ao longo da reflexão sobre o tema da "revolução".

Após os passeios iniciais pelos objetos centrais de análise, críticos, e conjunturas específicas em que foram produzidos, me permito estruturar o último Capítulo de maneira mais articulada: as proposições dos referidos autores e seus contemporâneos, acerca de uma gama de questões que circundam a problemática da "revolução" aparecem juntas, misturadas.

Isso posto, uma última dificuldade, inerente a todo trabalho comparativo, se apresenta: é preciso intentar um equilíbrio entre as considerações sobre uma e outra obras selecionadas. 
Contudo, na prática da análise, esse equilíbrio, hora e outra, se desfaz: há mais intérpretes que se dedicam a tal autor, há mais críticos que se concentram em tal aspecto, de determinada obra.

Minha opção foi, então, não pesar tal equilíbrio por número de parágrafos ou páginas dedicados a cada um dos livros, mas de seções e questionamentos que a eles se dedicam. Há, nesta Tese, o exato mesmo número de seções dedicadas a cada um deles; e as mesmas questões apresentadas para um, são apresentadas para outro.

É importante pontuar, logo, que, em comparação com El perfil, existe uma quantidade consideravelmente maior de obras sobre Raízes. E não me refiro ao volume de obras mexicanas sobre Holanda, se comparadas a um dado volume de obras brasileiras sobre Ramos. Refiro-me ao fato, puro e simples, de que, ao que tudo indica, no Brasil houve e há mais estudos sobre Raízes do que no México há estudos sobre El perfil.

É o que a declaração de Ortiz, supracitada, nos assegura.

Ademais, estando no México à procura de informações sobre Ramos e seu ensaio mais famoso, deparei-me com grandes dificuldades; e com uma situação curiosa: muitos professores mexicanos me perguntavam por que razão eu estudava Ramos, e não Paz ou Leopoldo Zea, cujas obras lhes pareciam mais interessantes.

Ora, não creio que o mesmo pudesse ocorrer no Brasil, com um investigador mexicano disposto a conhecer Holanda. Holanda, para nossos especialistas, está imensamente vivo em nossa vida acadêmica, inspirando estudos mais diversos sobre sua trajetória pessoal e intelectual, seus conceitos mais fundamentais, seu clássico mais célebre, suas pesquisas posteriores (ZAGAL, 2010).

Assim, se alguns fios ficam soltos em alguns pontos, considero natural: o trabalho de comparação não deve equivaler a um trabalho de enquadramento. As duas obras clássicas aqui por mim estudadas são, cada qual, universos complexos. E se, pela observação de uma, a outra parece abrir-se em dúvidas, são portas que se destrancam, são novos estudos que se vislumbram. 


\section{CAPÍTUlO 1:}

\section{Apresentando autores, obras, e temas: considerações iniciais sobre Raízes do Brasil e El perfil del hombre y la cultura en México}

\subsection{Considerações iniciais sobre Holanda e seu Raízes}

Como apontado na Introdução, o objetivo deste Capítulo é apresentar, didaticamente, cada um dos autores dos clássicos selecionados para análise. Nesta primeira seção, dedico-me a desenhar esquematicamente a trajetória de Holanda, até a composição de Raízes, apontando algumas questões básicas, a serem adiante retomadas: experiências, diálogos intelectuais, aspectos teóricos de seu referido ensaio, e também metodológicos.

Na próxima seção, concentro-me no conceito formulado por Holanda, em Raízes, que vem sendo considerado o conceito ali mais importante; o "homem cordial".

E, na sequencia, na terceira seção deste Capítulo, voltarei a tais questões, observandoas a partir do olhar dos críticos mais famosos de Holanda, sobretudo críticos interessados em sua fase como ensaísta.

Conforme as anotações feitas pela esposa Maria Amélia, Sergio Buarque de Holanda nasceu em São Paulo, em 1902 (HOLANDA, 1979, p. 422). Na capital paulista em franco desenvolvimento, contribuiu para algumas revistas e seções de Crítica Literária (Idem, p. 424).

Em 1921, mudou-se com a família para a então capital do país, o Rio de Janeiro, onde começou a cursar Direito. Paralelamente, Trabalhou para diversos jornais e agências de informação, e colaborou como crítico para inúmeros periódicos de Literatura e Arte, de maneira que, em pouco tempo, a formação como advogado ficou para segundo plano (Idem, p. 427).

Na década de 1930, foi professor assistente na extinta Universidade do Distrito Federal. Logo em seguida, na mesma instituição, tornou-se professor titular de História da América e História da Cultura Luso-Brasileira. Entre uma coisa e outra, em 1936, publicou, pela editora José Olympio, seu primeiro e mais famoso livro: Raízes do Brasil, que aqui será enfatizado (Idem, p. 434).

Convém seguir, entretanto, um pouco mais, na trajetória de Holanda, e destacar que os anos 1940 marcaram o retorno dele a São Paulo. De volta à cidade natal, foi diretor do Museu Paulista, e vice-presidente do Museu de Arte Moderna. Lecionou História Econômica e 
História Social do Brasil na Escola de Sociologia e Política em 1948, História do Brasil na Faculdade de Filosofia, Ciências e Letras de Sorocaba em 1956, e História da Civilização Brasileira, na Faculdade de Filosofia, Ciências e Letras da Universidade de São Paulo em 1957. No ano seguinte, obteve, pela USP, o "grau de mestre", com a tese intitulada Visões do paraíso (Idem, p. 438-441). Foi professor, ainda, em universidades estrangeiras: a Universidade de Roma e a Universidade do Chile (Idem, p. 440).

Holanda trabalhou, ao longo de sua profícua carreira, em inúmeras pesquisas sobre História Colonial brasileira e, depois, sobre o Brasil Império; elas resultaram na publicação de livros bastante celebrados, referência até hoje para nossos historiadores. Nesse percurso, ajudou a criar o Instituto de Estudos Brasileiros, em 1962 (Idem, p. 442).

Em se tratando especificamente de Raízes, porém, é necessário dizer que tem sido um livro bastante criticado. O foi inclusive pelo próprio Holanda, que afirmava preferir Visões do paraíso (1958).

Em entrevista à Tribuna de imprensa, de 1959, Holanda disse, sobre Raízes: "Hoje, provavelmente não o escreveria. Não propriamente que esteja em desacordo com o livro, mas não gostaria de escrevê-lo hoje” (Apud. MARTINS, 2009, p. 65). À Veja, em 1976, declarou que não se "aventuraria mais a tentar uma empreitada dessa espécie"; e narrou a seguinte situação: "Há pouco tempo uma editora francesa, a Gallimard, me propôs a tradução de Raízes do Brasil. Pediram-me também um ensaio, que seria publicado na edição francesa, atualizando minhas ideias. Tentei, mas acabei desistindo" (Idem, p. 85-86). Em seu último depoimento, do ano de 1981, um tanto mais cansado declarou que Raízes era um livro com o qual já não mais “concordava muito” (Idem, p. 157).

Porém, é curioso que os familiares, em documentário realizado por Nelson Pereira dos Santos, sobre a vida de Holanda, nos contem que o célebre intelectual brasileiro escolheu exemplares de Raízes, e não de Visões do paraíso, para autografar, e presentear os netos. Se não era por Raízes que ele desejava ser lembrado, ele reconhecia a importância fulcral do livro para sua vida e para sua carreira (SANTOS, 2003).

Além do mais, como veremos nas próximas seções, muitos críticos têm destacado Raízes como um livro essencial por uma série de fatores, dentre os quais: a elaboração de ricos conceitos, em alguma medida validos até hoje; a estrutura ensaística, mais solta, que teria permitido ao jovem Holanda alçar voos reflexivos mais altos; e as ricas e fundantes inovações teórico-metodológicas, para a época em que foi escrito.

Raízes do Brasil foi composto em seis capítulos: Fronteiras da Europa, Trabalho e aventura, O homem cordial, Novos tempos e Nossa revolução. 
Conforme Antonio Candido, em um famoso prólogo a edição bem posterior do livro, datado de 1967, Raízes foi um "clássico instantâneo" (CANDIDO, 1999, p. 10). Porém, ganhou uma nova edição apenas 11 anos depois; tempo que exigiu uma série de modificações. Como lembra Edgard Salvadori de Decca, “o livro Raízes que [fez] 70 anos em 2006 [então] não é o mesmo que foi publicado em 1936" (DE DECCA, 2006, p. 6).

Mudança bastante visível foi, por exemplo, a divisão do segundo capítulo em dois - $O$ passado agrário e $O$ semeador e o ladrilhador.

Conforme João Cezar de Castro Rocha, sobre o ensaio como um todo, a estrutura da versão atualmente publicada é consideravelmente mais clara e coerente do que a inicial. Nessa versão de hoje Holanda parece ter aprimorado o estilo, e investido em um tom menos marcadamente pessoal, e mais caracteristicamente relativista e sóbrio (ROCHA, 2006, p. 251); também teria investido na inclusão de dados que acabaram por conferir à obra o aspecto de maior precisão (Idem, p. 248, 250, 263).

Tais alterações, das mais óbvias às mais sutis, afinal, implicam grandes dificuldades para os estudiosos de Raízes: já um tanto ambíguo desde a primeira versão, por tratar-se de um ensaio, e por ter sido composto per se sem a pretensão de fechar conclusões, a leitura do texto de hoje se complexifica, num entremeado de tempos de leituras e escrituras. É preciso, assim, apurar bastante nosso olhar, a respeito dele, em interpretações que se esforcem por ser menos carregadas de pré-conceitos, mas que não deixem de se fazer cruzadas a outros textos, críticos, já também clássicos.

Um bom exemplo do caos teórico que envolve a escritura e a leitura de Raízes é que os mais diversos intérpretes observam, cada qual, no livro, a proposição, por Holanda, de distintas teses centrais.

Eu diria, em consonância com as reflexões aqui já apresentadas, e pautando-me em depoimentos de Holanda, concedidos pelas décadas de 1970 e 1980, que havia, em Raízes, como preocupação primeira, avaliar as possibilidades de uma "revolução" brasileira; ou, em outras palavras, avaliar se era possível instituir entre nós um jeito absolutamente novo e nosso de viver, de produzir, de nos relacionarmos - um jeito que então poderia ser chamado "revolucionário".

Ora, ao ver de Holanda, para bem compreendermos os problemas e as potencialidades do Brasil, fazia-se mister voltarmo-nos para trás, a entender o que havia hoje de continuidade e de inovação; a entender o que poderia ser considerado como inovação, por nós, e como inovação nossa, e mudança que nos satisfizesse. Holanda, assim, logo nas primeiras páginas do livro, dizia: “antes de perguntar até que ponto poderá alcançar bom êxito a tentativa [de 
implantação da cultura europeia neste trecho do continente americano], caberia averiguar até onde temos podido representar aquelas formas de convívio, instituições e ideias" (HOLANDA, 1999, p. 31).

Fato é que, logo no início de Raízes Holanda apresentava a realidade brasileira como reprodução e a inovação; como hiato entre o novo e o velho; como uma dúvida, uma interrogação. Holanda dizia, nas páginas iniciais de Raízes, que "somos ainda hoje uns desterrados em nossa própria terra" (HOLANDA, 1999, p. 31), mas demarcava que a própria condição de desterro, transplantação, implantação se fazia pelo viés da diferenciação. Na visão de Pedro Meira Monteiro, Raízes apresenta uma compreensão da "cultura brasileira" como "panorama civilizacional diverso" (MONTEIRO, 2006, p. 319); próprio, e não-se-sabe se inferior ou deteriorado.

Bom, se estamos falando - para usar palavras do referido ensaio - em "formas de convívio, instituição e ideias", considero fundamental avaliar o que Holanda considerou como “cultura”, em Raízes.

O historiador inglês Peter Burke destaca, da análise cultural feita por Holanda, em Raízes, o insistente uso de termos como "formas" e também "mentalidade", "visão de mundo" (BURKE, 2002). Eu sublinharia a composição das expressões "mentalidade católica", "mentalidade patriarcal/rural", "mentalidade de classe/burguesa" (HOLANDA, 1999, p. 37, $112,144)$. E, quanto à expressão "visão de mundo", lembraria que Holanda a aplica como um fundo sobre o qual se projetam criações artísticas e literárias (Idem, p. 116).

Daí que, Holanda, em Raízes, trate sim de "cultura clássica": "ideias", "teorias", concepções filosóficas, movimentos literários, e os considere importantíssimos para se compreender o Brasil e os brasileiros, de ontem e de hoje (Idem, 1999, p. 95). Porém, para ele "cultura" não se restringia a elaborações de uma elite letrada; nem tampouco tais elaborações deveriam ser consideradas o que há de mais relevante no arcabouço cultural de um país. Como transcrevi acima, Holanda não fala apenas em "formas de ideias", mas também de "formas de instituições" e "formas de convívio".

Holanda explorou, em Raízes, noções como: "associação", "hábitos de vida", "atitude", "moral", "ordem", "cultura material", "cultura urbana", "cultura técnica e capitalista”, “civilização agrícola”, “civilização de raízes rurais” (HOLANDA, 1999, p. 73, $98,101,166)$. O que nos faz pensar que seu entendimento acerca do conceito de "cultura" incluía dados abstratos, imateriais, e também materiais; realizações, valores, pensamentos, criações, e também movimentações, procedimentos, e costumes. 
Conforme Monteiro, a noção de "cultura" trabalhada em Raízes se centra num entendimento muito específico da ideia de "ação": diz respeito a algo como uma "corrente profunda que nos arrasta", uma "força subterrânea irresistível", que envolve toda a coletividade (MONTEIRO, 2006, p. 315). João Kennedy Eugênio endossa tal perspectiva, ressaltando da escrita de Holanda o interesse pelo que a história tem de vivo, orgânico, espontâneo, autêntico, singular (EUGÊNIO, 2006).

Burke nos lembra, então, que Holanda, em Raízes, trabalhava ainda com o termo "caráter brasileiro" (BURKE, 2002); e eu acrescentaria, num mesmo sentido, o uso do termo "psicologia". Em seu ensaio Holanda tratava, por exemplo, de um dado "caráter inglês", um "caráter dos povos do norte", um "caráter urbano", um "caráter brasileiro" (HOLANDA, 1999, p. 45, 53, 63, 146, 155, 158), e uma "psicologia dos povos ibéricos" (HOLANDA, 1999: 38). Falara em "psicologia", também, em um texto estampado, um ano antes da primeira publicação de Raízes, nas páginas da revista Espelho - refiro-me a Corpo e alma do Brasil: um ensaio de psicologia social (HOLANDA, 2006, p. 583).

Senão, vejamos: esse conceito de "cultura", equivalente a "caráter", e perceptível em formas de pensar, se organizar e se relacionar, fez de Raízes um livro que rompia com três tendências, bastante notáveis na produção intelectual do período.

Primeiro, se distinguia do modelo de estudo da história em voga, e que concedia foco a "grandes eventos", "grandes homens", "grandes feitos". Holanda, em Raízes, embora falasse tanto sobre Estado, raramente mencionava estadistas ou teóricos políticos.

Ademais, - isso quem observa é Eugênio - se afastava das elaborações românticas, que se centravam num "particular" "simplificado", e reduziam o nacional a "clichês", “padronizações" (EUGÊNIO, 2006, p. 425).

Por fim, rejeitava teorias raciais, e declarava que de maneira alguma poderia concordar que as características mais típicas dos brasileiros "provenham de alguma inelutável fatalidade biológica" (HOLANDA, 1999, p. 36).

É preciso reforçar, então, algo que, porém, me parece já bastante evidente: se Holanda se interessava pelo que há de fluido e móvel na maneira de ser dos povos, reagia ao entendimento do "caráter" e da "psicologia" nacionais como uma essência, como condição natural, como uma estrutura posta. Para Holanda elas eram, muito pelo contrário, elaborações históricas e complexas, portanto, mutantes.

Daí que Raízes nada tenha dos primeiros estudos de Psicologia, que se contentavam em catalogar personalidades. Lembrava os modernos estudos da Psicanálise, por compartilhar a mesma ideia de que as características mentais do homem são construídas, no decorrer dos 
tempos, em experiências vividas; e por compartilhar a ideia de que era preciso voltar ao passado sem um anseio saudosista ou lamentador, e sim com um olhar descolado, buscando denunciar falseamentos, remover concepções cristalizadas, e vislumbrar causas ocultas dos problemas presentes.

Como estudo cultural e psicológico ensaístico, pode-se supor que o livro de Holanda prescindisse de método. Porém, a leitura de Raízes não corrobora tal suposição.

Ali os argumentos não são apresentados aleatoriamente: para a composição de sua análise acerca do brasileiro moderno e suas raízes, Holanda trabalhou com a composição de "tipos", tal como foi de certa maneira comum, em análises de fins do século XIX. Ainda assim, é difícil conceber com quais desses analistas, que compuseram tipologias, especificamente, ele estava dialogando.

Em 1979, Holanda escreveu uma espécie de apresentação a uma coletânea de textos seus, publicados, há pouco, na imprensa brasileira - Tentativas de mitologia. Na introdução, declarou, oportunamente, que a dificuldade em se traçar heranças, influências e inspirações suas, no clássico ensaio, se dava e daria sempre, em grande parte por uma opção sistemática sua, por encobri-las. Ele confessava:

Parecia-me indispensável dissipar essas marcas, que eram um pouco como andaimes destinados a desaparecer na construção acabada. Com isso, com a preocupação de não sobrecarregar meus textos com nomes e citações de autores mal conhecidos da maioria dos leitores, sabendo que eles servem principalmente para impressionar os inseguros e os basbaques, (...) procurava alijar de meus escritos tudo quanto tivesse um ar de coisa postiça, e dar, com isso, ao conjunto, um aspecto de razoável espontaneidade (HOLANDA, 1979, p. 16).

Nesse plano: parece unânime que uma viagem ao exterior foi experiência importantíssima, que garantiu a Holanda acessar essa nova bibliografia, "mal conhecida dos leitores", e assim estabelecer bases mais confiáveis sobre as quais pudesse partir para inovar metodologicamente. Tal viagem acabou por ter como parte importantíssima do roteiro a Alemanha.

Como nos conta Maria Amélia, no final da década de 1920 Holanda foi à Europa como correspondente jornalístico. Esteve sobretudo em território alemão, onde tomou contato com muitos teóricos que seriam fulcrais em sua formação intelectual (HOLANDA, 1979, p. 431-432).

O valor das experiências alemãs de Holanda foram pontuadas e tantas vezes retomadas por Candido, no referido prólogo a Raízes, e também em outros textos. No prefácio de 1967, ele mencionou apenas autores alemães, com cuja teoria as proposições de Raízes pudessem 
estar dialogando. E, num artigo escrito quando da morte de Holanda, confirmou: "A estada em Berlim foi uma oportunidade para abrir ao seu conhecimento um campo novo", de maneira que tal livro - basicamente um livro sobre o homem brasileiro - deveria ser considerado, para Candido, como um livro “meio alemão" (CANDIDO, 1982: 7).

Monteiro concorda que "a despeito da recusa do historiador em declarar-se filiado, irrestritamente, a uma ou outra corrente teórica, é possível detectar, em Raízes do Brasil, uma forte marca do pensamento alemão". E, mais do que isso, para Monteiro, o sociólogo Max Weber "é certamente [o autor, da Alemanha, mais] fundamental para a compreensão do livro em questão" (MONTEIRO, 1999: 21).

Não é simples, contudo, considerar especificamente em que pontos Weber foi inspirador e determinante na estruturação do raciocínio de Holanda, em Raízes. Para usar uma expressão de Monteiro (Ibidem), Weber é “citado com parcimônia” pelo ensaísta brasileiro.

Por exemplo: em geral, os intérpretes classificam como weberiana a opção de Holanda por trabalhar com a elaboração de "tipos"; porque, de fato, Weber foi um dos mais expressivos sociólogos a explorar tal possibilidade metodológica. Porém, quando Holanda, na referida obra, alude à metodologia ali empregada, não menciona Weber; o sociólogo alemão não é invocado, claramente, em Raízes, como referência de estruturação do raciocínio, como referência para a composição dos percursos cumpridos pela análise.

Weber é, tão somente - mesmo que isso seja muito -, mencionado como inspiração para a definição dos conceitos, das ideias acerca do homem moderno.

Para Candido, longe de "aplicar" o método weberiano, Holanda utilizou o autor alemão como fonte de inspiração; "aproveitou" "critérios", "modificando-os"; simplesmente teria dialogado com Weber, para dedicar-se à criação de um modo original de se interpretar o Brasil (CANDIDO, 1999, p. 12).

Não cabe nos alongarmos aqui, sobre os possíveis diálogos entre Holanda e Weber, na composição de Raízes, porque tal debate é demasiadamente vasto e recente, ademais de repleto de meandros. Esmiuçar tais aspectos seria, de fato, interessante para um estudo focado em Holanda, mas não para esta comparação. A opção por desdobrar tal universo de questionamentos traria consigo, para este estudo comparado, dois riscos: pesar demasiadamente a análise para Holanda, deixando os fios soltos no que diz respeito a Ramos; e/ou ousar na apresentação de pressuposições bastante vazias, a respeito de El perfil.

Hora, então, de seguir adiante na apresentação esquemática dos debates sobre a composição metodológica de Raízes, lembrando que, de acordo com muitos intérpretes, 
haveria outro sociólogo alemão, não citado por Holanda, mas que pode tê-lo influenciado: Georg Simmel.

Decerto, Holanda apresenta em Raízes conceitos e definições que são notavelmente semelhantes aos "tipos" compostos por Simmel, em seus estudos sobre a Alemanha, a Europa modernas. ${ }^{6}$ Porém, há uma forte e consistente tendência, entre os leitores mais célebres de Raízes, em destacar que não é na composição de conceitos, mas na abordagem metodológica que Simmel se destaca como uma possível leitura de Holanda: a forma com que o argumento se constrói em Raízes se pareceria muito mais com a forma como Simmel apresenta suas reflexões, do que com a forma trabalhada por Weber.

Candido, no dito prólogo a Raízes, pontuou: o "ritmo despreocupado e às vezes sutilmente digressivo (...) faz lembrar Simmel” (CANDIDO, 1999, p. 10). E, em outro texto, acrescentou: Holanda "por mais minuciosamente informado e documentado que esteja, não hesita em dar saltos qualitativos quase mortais, como os de (...) Simmel” (CANDIDO, 1982, p. 7).

Gabriel Cohn, num mesmo sentido, considerou que o que aproximava a escrita de Holanda, em Raízes, e de Simmel, em seus diversos ensaios, era um dado "fluxo espontâneo" (COHN, p. 10-11).

Monteiro, por fim, também fala da proximidade entre Holanda e Simmel, pelo comum "estilo digressivo", "ritmo pulsante" dos pequenos detalhes, e busca por uma "significação ampla" (MONTEIRO, 1999, p. 67).

Para terminar, proponho, pois, que atentemos especificamente para a explicação apresentada por Holanda para sua opção metodológica pela formulação de tipos sociológicos; e, em seguida, que nos voltemos a Weber, Simmel e seus comentadores, buscando avaliar em que medida Raízes se aproximava da maneira como esses dois autores alemães encararam a elaboração de tipologias.

Em Raízes, Holanda definira: "É claro que, em estado puro, (...) [os tipos não] possuem existência real fora do mundo das ideias"; "mas também não há dúvida que (...) nos ajudam a situar e a melhor ordenar nosso conhecimento dos homens e dos conjuntos sociais" (HOLANDA, 1999, p. 45).

Quer dizer, Holanda deixara bem claro que não acreditava existir algum brasileiro que, na realidade, correspondesse a um "tipo"; ou que os brasileiros reais, como um todo,

\footnotetext{
${ }^{6}$ Refiro-me ao conceito de "aventura", que, como veremos, Holanda contrapõe ao te "trabalho"; e que parece replicar, de alguma maneira, o conceito de "aventura" de Simmel, contraposto ao de "sedentarismo". Cf. (WAIZBORT \& GOLDFEDER, 2009, p. 21).
} 
pudessem corresponder a tanto. Conforme a argumentação transcrita, todos os tipos propostos em Raízes eram nada mais que abstrações; inclusive o tipo elaborado para análise específica do modo de ser e viver no Brasil.

Além disso, ao que me parece, Holanda não considerava que a elaboração de uma tipologia fosse a finalidade primeira de seu ensaio. Mais do que itens de um catálogo de classificação, seus tipos eram ferramentas elaboradas a partir da análise do real, a serem empregadas em novas avaliações acerca das nuances nas conformações, e mobilidades que caracterizam o real.

Conforme Cohn, afinal, a opção de Holanda por trabalhar "tipos" se aproxima da opção de Weber por trabalhar com "tipos ideais" justamente por isso. Weber, tal como Holanda, em Raízes, compreendia não haver existência social dada/estabelecida, aquém das formas de entendimento acerca dela. E que, portanto, era interessante colocar às claras os parâmetros de analise, as ferramentas de intervenção investigativa (COHN, 2002, p. 10-11).

Num mesmo sentido, ao ver de Monteiro e Leopoldo Waizbort, Holanda se aproximava de Simmel justamente pela comum compreensão da História como construção do pensar humano. Tanto os "tipos" formulados pelo brasileiro, quanto os "tipos ambíguos", formulados pelo alemão, então, corresponderiam à evidenciação de que a análise dos fios do tecido social é um trabalho de criação (MONTEIRO, 1999, p. 84; WAIZBORT, 2009, p. 17).

E foi à luz de tais concepções antropológicas e debates sociológicos, logo, que Holanda, nos quatro primeiros capítulos de Raízes, percorreu todo um universo de fontes sobre o passado colonial e imperial brasileiro; e assim conformou uma base, sobre a qual elaborou, no capítulo quinto, o conceito mais fundamental de sua obra.

Tal conceito serviu, então, como ferramenta para abordar, nos dois capítulos finais, que considero os mais importantes, períodos recentes da história nacional. Ele - o conceito de "homem cordial" - será analisado em detalhes na próxima seção deste Capítulo (HOLANDA, 1999, p. 146-147). 


\subsection{Essa tal cordialidade}

Em Raízes Holanda descreveu o "homem cordial" da seguinte maneira:

a lhaneza no trato, a hospitalidade, a generosidade, virtudes tão gabadas por estrangeiros que nos visitam, representam, com efeito, um traço definitivo do caráter brasileiro, na medida, ao menos, em que permanece ativa e fecunda a influência ancestral dos padrões de convívio humano, informados no meio rural e patriarcal. Seria engano supor que essas virtudes possam significar 'boas maneiras', civilidade. São antes de tudo expressões legítimas de um fundo emotivo extremamente rico e transbordante. (HOLANDA, 1999, p. 146-147).

Partindo de tal definição e dos desdobramentos que Holanda propôs a ela, entre os capítulos cinco a sete de Raízes, Robert Wegner pontua que "talvez o leitor fique indeciso (...) se afinal (...) a 'cordialidade' é uma virtude ou um defeito do brasileiro, e se o [Holanda] está a denunciar a sua derrocada ou permanência” (WEGNER, 2006, p. 336).

E fato é que, se Holanda não é suficientemente claro no texto de Raízes, a respeito do "homem cordial", os textos assinados ou atribuídos a ele, datados de anos e décadas posteriores, não deixaram de ser ambíguos, quando voltaram à questão. Chega a ser engraçado ler Holanda atendendo aos entrevistadores, e reagindo entre orgulhoso e aborrecido, tal como um velho e talentoso cantor, que fez sucesso com uma música só; e resulta incômodo como o fio de entendimento se perde, em seus argumentos, por vezes prováveis transcrições mal feitas de suas declarações.

É famoso, a respeito, o texto, datado de 1948, em que ele afirma considerar ser inútil "gastar tanta vela" com o "defunto" homem cordial; mas são também bem conhecidas as inúmeras entrevistas concedidas a respeito, posteriormente, em jornais e revistas de larga divulgação, nas quais parece insistir, embora com tom de descaso, que o brasileiro seguia sendo "cordial".

Em entrevista de 1977, à Folha de São Paulo, o desacerto de ponderações se repete, e ganha graça pelo excesso de "mas", que indica, afinal, que Holanda não pôde jamais ser conclusivo, a respeito do emprego da palavra "cordialidade", em Raízes: "Hoje, usaria outra. Mas não vou renegar o que eu escrevi há 40 anos. Mas nunca disse que o brasileiro é bonzinho" (Apud. MARTINS, 2009, p. 97).

Assim, reservo as seguintes páginas à composição de uma espécie de "história do termo cordialidade"; e a apresento em vários vieses, e a partir de diversas fontes e autores, para buscar compreensões mais radicais e articuladas, sobre o que Holanda tratou de sistematizar e propor, a respeito, em Raízes. 
A ideia é que, ao terminar de ler esta seção, o leitor acabe por compartilhar comigo uma percepção do "homem cordial", definido por Holanda, na versão original de sua obra, como conceito que envolve quatro dimensões principais: espontaneidade e passionalidade; descaso frente às normas impessoais coletivas, articulado à sempre latente possibilidade de viver e mesmo preferir um regime político ditatorial; a proximidade física, e o discurso que disfarça a violência da desigualdade de condições e oportunidades; e, por fim, a confusão entre obrigações e bens públicos e privados.

Corpo e alma do Brasil, artigo que foi publicado por Holanda um ano antes de Raízes, e que continha as principais ideias ali posteriormente desenvolvidas, começava por apresentar o conceito de "homem cordial", marcando que havia sido elaborado por Ribeiro Couto.

Essa menção a Couto não aparece explícita no texto de Raízes, mas na segunda edição dessa obra, datada de 1948, Holanda tratou de acrescentar uma nota, que ficou célebre, na qual reforçava que o "homem cordial" era uma expressão tomada de uma carta escrita por Couto em 1931; uma carta endereçada ao intelectual mexicano Alfonso Reyes, que posteriormente a publicou na revista que editava, a revista Monterrey (HOLANDA, 1999, p. 204).

Efetivamente, em tal texto de Couto, republicado na edição comemorativa dos 70 anos de lançamento de Raízes, lê-se uma definição que lembra bastante a definição de Holanda, em Raízes. Em tal texto Couto falava que um dito "homem cordial" seria a grande "contribuição" que nós, latinoamericanos, estaríamos “dando ao mundo” (COUTO, 2006, p. 397-398).

Ainda assim, considero que a definição de Couto diferia da de Holanda, em dois pontos principais. Em primeiro lugar, para Couto o "homem cordial" era "produto americano"; enquanto para Holanda, brasileiro. Em segundo lugar, ao ver de Couto a raça nova que ia surgindo na América, por miscigenada, seria intuitiva e amorosa ("hospitaleira", “crédula", "sentimentalmente disponível"), escapando ao "egoísmo europeu” (COUTO, 2006, p. 398); e na definição de Holanda "cordialidade" poderia implicar, por vezes, comportamentos problemáticos e deletérios.

Há autores que afirmam que esse conteúdo crítico e negativo da cordialidade não apareceu de forma muito clara na primeira edição de Raízes; dentre os quais Cassiano Ricardo, que se engajou em um alongado e conhecido debate com Holanda. Holanda insistia que o confronto era inútil, porque Ricardo partia de pressupostos absolutamente distintos. Mas, conforme Ricardo, em texto publicado em 1948, “o que se vê (...) é que [na segunda edição] Sergio Buarque reexamina o conceito de 'homem cordial' e agora sob novos aspectos, 
que não figuravam [antes]". "Já isto me honra muito, demonstrando, pelo menos, que a minha discrepância não era, de todo, gratuita", escreveu o intérprete (RICARDO, 2006, p. 366).

De fato, na primeira como na atual edição de Raízes, Holanda usa, tal como Couto, os termos "contribuição para a civilização", que em si subentendem positivação. Ademais, em ambos os casos Holanda, assim como Couto, parte de um mesmo dado para começar a definir a "cordialidade": a impressão corrente entre os estrangeiros que visitam a América Latina, e Brasil, de que o povo latino-americano, o povo brasileiro, seria um povo, felizmente, alegremente, adoravelmente hospitaleiro.

Para Ricardo, era justamente bondade e brandura que mais caracterizavam o brasileiro, e configuravam nossa contribuição maior à civilização humana: "de todos os defeitos humanos parece que o único verdadeiramente incorrigível do brasileiro é esse: passar da conta de ser tão bom" (Idem, p. 387); "violências, ditaduras e quejandas invenções da força são flores rubras que não vicejam, absolutamente, em nosso clima local” (RICARDO, p. 385).

Além disso, embora Ricardo também usasse a expressão "homem cordial", criticava que Holanda, ao trabalhar com ela, partisse da etimologia da palavra, quer dizer, da designação original, ligada a "cordio", do coração; criticava que Holanda, assim, se esquecesse, afinal, que atualmente "cordialidade" queria dizer "boas maneiras".

Para Ricardo, então, ao optar por falar em "cordialidade", Holanda se equivocava de duas formas: por um lado, evitando apontar como definitivo no brasileiro algo que o é, e, por outro, definindo-a com um termo que confunde. "Pretendendo explicar a palavra, Sergio alterou, descaracterizou o nosso homem cordial”, concluía (RICARDO, 2006, p. 375). ${ }^{7}$

Em entrevista à revista Veja, de 1976, Holanda propôs, a respeito: “Tem havido muita discussão, recentemente, a respeito da história do Brasil, se ela é cruenta ou incruenta. Considero esse debate bizantino" (Apud. MARTINS, 2009, p. 85) - quer dizer: um debate

\footnotetext{
${ }^{7}$ Não cabe aqui ir tão fundo na discussão proposta por Ricardo sobre as opções feitas por Holanda no que diz respeito à escolha do termo "cordialidade". $\mathrm{Na}$, para mim fundamental, reflexão acerca dos significados propostos a ele, tal discussão me parece um desvio de rota. Por isso a incluo, em alusão esquemática, apenas nesta nota:

Ricardo lembrava que Holanda partira da etimologia da palavra "cordial", para fundamentar que equivalia a tudo que diz respeito ao "cordio", ao "coração". Mas, insatisfeito, sublinhava que assim o ensaísta ignorara os usos modernos da palavra; ignorara e que "cordial" há muito, em nossa fala, corresponderia à polidez, e à civilidade que, em Raízes, eram demarcadas como tão pouco características do brasileiro.

Ao ver de Ricardo, ademais, entre a significação "erudita" e corrente do vocábulo, Holanda teria acabado por centrar a análise das especificidades brasileiras num duplo falso: colocar o afetivo no centro das relações não era hábito suficientemente exclusivo de nossa nação, e nem absolutamente avesso às normas objetivas de comportamento político-social. Ricardo pontuava, afinal, que conforme seu entendimento "mesmo hoje, com os males do racionalismo e da mecanização, [os] sentimentos permanecem" (RICARDO, 2006, p. 373); e que, afinal, conforme seu entendimento, "qualquer pessoa esquece por um momento todo o convencionalismo e formalismo" (Idem, p. 372).
} 
acalorado, em razão do Brasil na corrente década de 1970 estar vivendo um período político violento, ditatorial; ainda que um debate sem transcendência alguma.

Todavia, na sequencia, nessa mesma entrevista, Holanda apresentava uma série de proposições e contraposições que nos fazem perder a linha de seu raciocínio.

Isso porque, embora afirmasse, ali, ser a discussão vã, ele não consentia em perder a oportunidade de sublinhar, mais uma vez, que sua definição de "homem cordial" diferia da definição traçada por Ricardo. Repetia que, diferentemente de Ricardo, sua definição não tomava como vértice a ideia de doçura, de bondade.

Porém, paradoxalmente, - lê-se na sequência do texto da entrevista - teria afirmado, bem ao modo de Ricardo, ser "inegável que a independência, a proclamação da República e mesmo as revoluções de 1930 e 1964 se fizeram sem derramamento de sangue"; e que, "portanto", "a cordialidade continua valendo" (Apud. MARTINS, 2009, p. 85).

No ano seguinte, em entrevista à Folha da tarde, ele negou, é verdade, alguns pontos publicados pela Veja, referentes ao "homem cordial": "aquele cabeçalho não é invenção minha, é de invenção deles lá”. Contudo, pareceu admitir que as confusões a respeito eram em parte sua culpa: "hoje, não usaria essa expressão porque é ambígua e se presta a essas dúvidas" (Idem, p. 96-97).

Fato é que Holanda jamais chegou a dizer, nas diversas edições de Raízes, como fez Ricardo, que a cordialidade se estruturava sobre uma base psicológica definida pelo princípio da "bondade". Em nenhum momento Holanda deixou de pontuar, de forma suficientemente clara, que considerava a cordialidade como problemática, no Brasil.

$\mathrm{E}$, se ele partia da ideia de que os estrangeiros nos tomavam como hospitaleiros, nas últimas páginas de Raízes, pontuava: "Com a simples cordialidade não se criam os bons princípios. É necessário algum elemento normativo sólido (...) para que possa haver cristalização social" (HOLANDA, 1999, p. 185).

Quanto à bondade brasileira, em Raízes definia que, embora aparecesse quase sempre como referência fundamental, nos discursos, no Brasil, não eram necessariamente em geral observáveis em nossas práticas sociais. De maneira que, entre nós, ela corresponderia, afinal, a uma questão superficial, simbólica, e não efetiva: preferirmos ser vistos como "um [país] gigante cheio de bonomia superior para todas as nações", e quase sempre "não [ambicionarmos] o prestígio de país conquistador, [detestarmos] notoriamente as soluções violentas" (HOLANDA, 1999, p. 177). E, contudo, sabemos ser violentos com nossos pares e também com estrangeiros. 
A bondade brasileira era proposta, então, em Raízes, como uma "máscara" (Idem, p. 147). Escondia questões psicológicas, emocionais, mais profundas. O brasileiro, conforme o texto de Raízes, costumaria lançar mão de "padrões" postiços de atuação, "formas" ilegítimas de convivência, "mímicas", falseamentos, ilusões. "A polidez é, de algum modo, organização de defesa ante a sociedade, (...) peça de resistência”, disse nosso ensaísta (Idem, p. 147).

A bondade brasileira, assim, denotaria certo desprezo por si mesmo; um mal querer, dos brasileiros, em relação a si. Ao ver de Holanda, em Raízes, o brasileiro sente "pavor (...) em viver consigo mesmo", por isso busca "viver nos outros" (Idem, p. 147).

De fato Holanda não explicita, em Raízes, que era um sentimento de inferioridade, supostamente característico do brasileiro, que ofuscava e deturpava a nossa percepção de nós mesmos, e nosso comportamento. Mas isso havia ficado bem claro no texto sobre psicologia nacional que publicara um ano antes, o já mencionado Corpo e alma do Brasil, onde lemos: "um certo complexo de inferioridade, (...) contrasta em absoluto com o que há de mais positivo em [nosso] temperamento" (HOLANDA, 2008, p. 591).

Lembremos, ainda, que na mesma nota introduzida à segunda edição de Raízes, em que Holanda apresentava Couto como criador do termo "homem cordial", outro autor era proposto como referência fundamental na estruturação do conceito de "cordialidade". Tratava-se do pensador alemão Carl Schmitt, que há pouco publicara $O$ conceito de política (1933), folheto que continha uma síntese das ideias de Schmitt, e que vem sendo negligenciado pelos mais diversos intérpretes do clássico ensaio, com, creio, exceção apenas de João Cezar de Castro Rocha (ROCHA, 2000).

O leitor pode argumentar que o diálogo com esse pensador alemão, por parte de Holanda, pode ter ocorrido nos anos que separaram a versão original do livro, de 1936, e essa outra versão, de 1948; e que portanto não seria determinante da formulação inicial do célebre conceito, do célebre ensaio. Porém, um texto estampado por Holanda nas páginas do jornal Folha da manhã, em 1935, nos leva a descartar tal hipótese: ali Holanda resumia e criticava as principais ideias de Schmitt, já com foco em concepções centrais para a análise da sociedade brasileira moderna, constantes em Corpo e alma do Brasil, do mesmo ano, e Raízes, do ano seguinte.

Tais conexões, ademais de complexas - porque os percursos cumpridos pelo raciocínio de Holanda não são claros -, são obtusas - porque não há estudos específicos, a respeito. Fundamental, destarte, sermos cuidadosos; considerarmos definições, desdobramentos, e relações entre conceitos. 
Comecemos do princípio: no aludido texto publicado na Folha da manhã, Holanda explicava e endossava a hipótese de Schmitt, de que as noções de "amigo" e de "inimigo" é que definem os agrupamentos sociais, e, então, os ordenamentos políticos; de que o "irracional, que tem sua raiz nas regiões obscuras, inconscientes do homem" seria politicamente e "concretamente" mais determinante do que "princípios morais e jurídicos", “abstrações vazias” (Apud. BARBOSA, 1988, p. 299-300).

Mas fato é que, na aludida nota incluída na segunda edição de Raízes, Holanda não só reforçava que "cordialidade" dizia respeito não necessariamente ao que é bom, suave, cândido; que ela poderia se nutrir de sentimentos "positivos" como "negativos", e se fazer presente em relações de "aproximação" como de "discórdia" (Apud. HOLANDA, 1999, p. 205). E ele tratava, nessa nota, ademais, de apontar Schmitt como um interessante pensador que trabalhou a diferenciação entre dois tipos de sentimentos/relações negativos, a inimizade e a hostilidade, associando a primeira ao universo íntimo e familiar, e a segunda ao público, coletivo.

Daí podemos concluir, preliminarmente, que Holanda de certa forma partiu de Schmitt para reforçar que o homem brasileiro, pleno de paixões, nutria profundos sentimentos de amizade e de inimizade, não conformes a padrões amplos e talvez mais abstratos; e sim num sentido circunscrito às dinâmicas pessoais, de sangue e compadrio. Podemos concluir, também, que Holanda de certa forma parte de Schmitt para reforçar o aspecto mais importante e diferenciador do "homem cordial": a predominância do privado sobre o público.

Em resumo, eu diria, então, que a referência a Schmitt ajudou Holanda a observar, no Brasil, a explosão do sentimental, irracional, pessoal, para além dos limites do lar, em direção ao espaço coletivo, do político; e nos ajuda a sublinhar, no conceito de "cordialidade", de Raízes, a importância não da sobreposição da ideia de "bondade" sobre a de "maldade", mas da de privado sobre a de público.

Como se não bastasse, a confusão aumentou alguns anos depois da segunda edição de Raízes, com Oswald de Andrade. Em Um aspecto antropofágico da cultura brasileira (1950), o poeta paulista partia de transcrições de trechos célebres de Raízes, para propor ideias, em seu cerne, notavelmente distintas das de Holanda (ANDRADE, 1995: 157).

Sem mencionar Couto, Oswald se aproximava do texto publicado em Monterrey, não apenas por abordar a conformação do homem cordial como paradigma alternativo ao "desenvolvimento egotista do indivíduo dentro das sociedades civilizadas", mas também a questão das trocas culturais (ANDRADE, 1995, p. 158). 
Porém, curiosamente ou até mesmo paradoxalmente, num salto se afastava de Couto, Holanda e Ricardo, abandonava a ideia de que seria corrente entre os estrangeiros a impressão de que seríamos dóceis, e abordava o fato de sermos, constantemente, vistos como bárbaros. Para ele, de forma muito específica, embora bárbaro na visão dos outros, ou conforme o olhar dos outros, o brasileiro seria consideravelmente emotivo com seus iguais (ANDRADE, 1995, p. 159).

Nisso, está claro, Oswald inova, mas também retoma um contraste constitutivo da definição de "homem cordial", por Holanda, e ausente em Ricardo: o contraste entre as ideias de "ferocidade" e "lhaneza no trato".

Oswald replicava, também, uma oposição tomada de Schmitt por Holanda, qual seja, entre inimizade e amizade, e apresentava a definição do brasileiro, do nacional, pelo conflito com o estrangeiro, e pela identificação com o próximo, o conterrâneo.

Para finalizar, eu diria, então, que, embora o termo o "homem cordial" não tenha sido uma criação de Holanda, e embora tenha sido empregado em um sentido bem próprio, em Raízes, foi a partir de Holanda, foi a partir de Raízes, que se estabeleceu um rico debate, sempre atualizável, sobre os modos de ser dos brasileiros. Conforme Lilia Mortiz Schwarcz, Holanda foi um "mal visionário de si próprio": ele costumava dizer que "os livros (...) "são a vida em comprimido' e fazem do historiador 'presa fácil de seu tempo'”, mas, ao ver da historiadora, os conceitos formulados por ele em Raízes "escaparam a seu tempo e não se deixaram aprisionar”. (SCHWARCZ, 2008, p. 88).

Em meio a tantas leituras e interpretações, fica difícil assegurar, afinal, o que Holanda tinha em mente quando apresentou o conceito de "homem cordial", na versão original de Raízes.

Porém, pautando-me nos mencionados outros textos que ele publicou ao longo da década em que lançou seu ensaio mais célebre, quer dizer, a década de 1930, e também, em algumas leituras que ele indicou ter feito, naquela época, e que teriam sido importantes como base das perspectivas apresentadas no ensaio, sobre o brasileiro e o Brasil modernos, nos permitem tirar algumas conclusões gerais.

Eu diria, assim, que para Holanda, em Raízes, "cordialidade" não compunha a "essência" do brasileiro. Era perceptível em seus comportamentos e discursos: era estratégia de inserção social; era justificadora de toda espécie de desejo - racional, irracional, consciente ou subconsciente.

Ora, a meu ver, justamente nessas duas medidas a ideia pôde ser deslocada dos princípios do século XX, como lente através da qual contrastamos ainda hoje algum 
amadurecimento ou algum teimoso hábito; de nossas falas e de nossos padrões de ordenamento político. 


\subsection{Leituras de Raizes}

Considerei na seção anterior como variou a percepção de Holanda acerca do conceito, por ele formulado, de "homem cordial"; agora é hora de repensar como o Holanda maduro, historiador especialista, observou o estilo de escrita do qual lançara mão em Raízes.

São duas as principais críticas apresentadas ao referido clássico; e, de fato, há depoimentos de Holanda que em certa medida corroboram ambas. Por um lado, diz-se - e Holanda chegou a concordar - que tal livro apresentava o desenho de uma identidade brasileira, e assim cumpria iniciativa conservadora, condizente com os interesses do então governo instituído, no Brasil. Por outro, diz-se - e Holanda tendeu a endossar isso - que tal livro era, afinal, pouco preciso, vago em suas colocações.

A presente seção se dedica justamente a avaliar esses dois corpus de críticas, para, então, reconsiderar os parâmetros que têm pautado as avaliações a respeito de Raízes. A ideia é, a partir disso, ponderar a possibilidade de que esses parâmetros tenham se estabelecido levando menos em conta as concepções teóricas de Holanda, a respeito da cultura brasileira; a metodologia da qual ele dispôs em Raízes; as formulações fluidas de "homem cordial"; e mais os contextos outros, nos quais escreviam os debatedores.

Na segunda metade da década de 1960, marcada, no Brasil, pela ditadura militar, em palestra proferida na Escola Superior de Guerra, Holanda ousou registrar publicamente sua crítica ao hábito de governos autoritários se fixarem em modelos fechados de identidade nacional. Para tanto, considerou seu texto de juventude, negativamente; e disse:

Houve tempo em que eu julguei relativamente fácil e, mais do que fácil, necessário, explicar-me a mim mesmo ou, se possível, tentar explicar a outros os traços distintivos da entidade misteriosa e, por menos que o queiramos, ainda indecisa a que se chama o homem brasileiro. Parecia essa necessidade uma imposição tanto mais imperiosa quanto devia corresponder a uma espécie de exame de consciência pessoal, além de nacional (HOLANDA, 2008: 617).

Em outras palavras, naquele momento Holanda declarava considerar que suas reflexões sobre a "psicologia nacional", expostas em Raízes, tinham correspondido a uma tentativa vã, porque o "homem nacional" seria, a seu ver, uma "entidade misteriosa", incapturável. Ele reconhecia, ainda - ou sobretudo - que o fizera atendendo a uma demanda daquela época, da década de 1930.

Nos anos 1950, Dante Moreira Leite pontuara, num mesmo sentido, que Raízes apresentara compreensões duvidosas e comprometidas "ideologicamente". Conceito que, aliás, é bem caro a Leite: para tal intérprete, era "ideológica" toda definição de um "caráter", 
toda redução de um povo a uma "psicologia", na medida em que servia menos à ciência, ao conhecimento sobre esse povo, do que à política; na medida em que servia menos ao processo de conscientização crítica, do que de conformação e alienação (LEITE, 2007, p. 39).

Naquela mesma década, Roland Corbusier, do diretor do Instituto Superior de Estudos Brasileiros, igualou Raízes a escritos de Cassiano Ricardo, Paulo Prado e Gilberto Freyre, pela comum "falta de consciência crítica de história" (Apud. MOTA, 2008, p. 206).

Carlos Guilherme Mota, duas décadas depois, já com o regime militar em vigor, no Brasil, partiu também da noção de "ideologia", para propor que Holanda, tal como quase toda a geração de ensaístas da década de 1930, havia promovido uma "crítica (talvez demasiado erudita e metafórica para o incipiente e abafado ambiente cultural e político da época)”, perpassada por notável "saudosismo aristocrático" (MOTA, 2008, p. 72-73).

Ao ver de Mota, a conformação de um "pensamento verdadeiramente crítico", no Brasil, teria partido de autores em relação aos quais Holanda, à época de Raízes, foi marcadamente crítico - como Caio Prado Junior - e autores que, em gerações posteriores, foram críticos a Raízes - como Florestan Fernandes (Idem, p. 65).

Alfredo Bosi, de sua parte, considerou Raízes como "ensaísmo histórico de causas étnicas, das concausas geográficas e das subcausas psicológicas, descontraído (...) pela prática modernista"; e que negligenciaria questões supostamente mais centrais, como a "dialética de classes" (BOSI, 2008, p. 36).

Como primeiro passo no diálogo com tais críticas faz-se mister identificar que a declaração de Holanda, na Escola Superior de Guerra, nos diz muito - talvez sobretudo - a respeito do período em que foi elaborada, quer dizer, a respeito da ditadura militar - um momento histórico específico, com demandas e compreensões específicas, acerca da importância dos estudos de história.

Tais comentários de Holanda a respeito de Raízes, datados de 1967, pois, talvez não devam, simplesmente porque foram proferidos pelo autor do clássico, ser considerados como interpretação final e irrebatível. Porque pode ser que eles não se tenham proposto considerando atentamente o universo de questões que envolveu mais especificamente a elaboração da dita obra.

Quanto a Leite, Mota e intelectuais do ISEB, como aponta Piva, não puderam tampouco deixar de apresentar entendimentos acerca de Raízes sobretudo vinculados a seus tensos contextos de formação e produção intelectual - as décadas de 1950 a 1970. Tais análises condenatórias estariam, para usar palavras de Piva, "marcadas pela valorização exclusiva dos temas do desenvolvimento econômico e do nacionalismo autárquico dos anos 
cinquenta [e do autoritarismo dos setenta], e perdem com isso" (PIVA, 2000: 51). Para Piva os críticos de Holanda por vezes "arrancam a fórceps", do referido clássico, sentidos que lhes interessavam (PIVA, 2000, p. 85).

É preciso dizer, contudo, que os livros de Leite e Mota diferem em alguns pontos essenciais. Por exemplo: Mota considera a interpretação de Leite como identificada ao liberalismo da década de 1950; e apresenta a sua própria como, essencialmente, crítica de esquerda, anti-governo militar.

Para Mota, Leite propõe "o fim das explicações através do caráter nacional”, e a noção pura e simples de "povo", por pretender a dissolução das diferenças entre brasileiros e estrangeiros, e entre os estratos sociais, em nosso país. A seu ver, Leite apostaria que "desaparecendo" o brasileiro, surgiria "a mão de obra livre e despojada de suas características culturais”, com, ademais, a noção de classe “eclipsada” (MOTA, 2008, p. 284).

Quanto a suas próprias considerações, Mota classificou como formuladas durante anos severos da ditadura militar, para jovens estudantes universitários que ansiavam por se posicionar em meio à produção intelectual brasileira sobre o Brasil - suas tradições e modernidades (Idem, p. 7).

Ao invés de amalgamar referências prontas, às quais a juventude pudesse se vincular/filiar, Mota teria escolhido, então, assumir uma postura de crítica extremada. É assim que, ao mesmo tempo em que aponta como problemática a composição dos clássicos ensaios da década de 1930, dentre eles o ensaio de Holanda, apresenta a reflexão de Leite como ideologicamente comprometida e por isso ambígua. Nesse sentido, seu trabalho acadêmico que virou obra-referência mereceu, por ele próprio, como autor, recentemente, a denominação de "a tese universitária iracunda de 1975", e de Candido, em 1978, quando ela foi publicada pela primeira vez, a denominação de "livro do contra" (Idem, p. 12).

Soma-se a isso o fato de que Leite dedica todo um capítulo de seu livro a Holanda, mas não Mota. No que diz respeito à produção de reflexões sobre a cultura brasileira, nos anos 1930, Mota foca os trabalhos de Gilberto Freyre e Caio Prado Junior - o primeiro, para condenar; o segundo, para apontar como referência. Quando se refere a Holanda, suaviza e chega mesmo a enfatizar a preocupação, em Raízes, com a denúncia do "autoritarismo e perspectivas hierárquicas" (Idem, p. 72).

Em textos mais recentes, aliás, Mota parece mesmo insistir em replicar os argumentos de Holanda, esboçados em Raízes, sobre o comportamento político nacional. Ele lamenta, por exemplo, "o Brasil sempre ter sido província do conservadorismo profundo e matreiro, aberto e cordial, no mais das vezes disfarçado" (MOTA, 2008n, p. 21). 
O segundo passo para rebater as críticas mais comuns a Raízes é voltarmo-nos à primeira seção deste Capítulo, na qual enfoquei a metodologia da qual ali teria disposto Holanda - quer dizer, a formulação de tipos, de inspiração sociológica, alemã. Como vimos, conforme explicitava o dito ensaísta nas páginas da referida obra, os tipos ali apresentados dentre os quais o tipo nacional, o "homem cordial" - "não possuem existência real fora do mundo das ideias" (HOLANDA, 1999, p. 45); e, conforme apontam seus intérpretes, leitor de Weber e Simmel ele tinha a pretensão de, por meio dos tipos, repensar formas de analisar o social, e não de enquadrar o social.

Ora, ainda assim houve quem considerasse o "homem cordial" de Raízes como um conceito que, à época, foi lido e serviu como referencial fundamental, com o qual se identificassem os cidadãos de nosso país. Nessa perspectiva, Holanda teria acabado por contribuir, de alguma maneira, aos interesses do ditador empossado militarmente e em exercício desde a chamada "Revolução de 1930". A propósito, Edgard Salvadori De Decca sublinha que "todo sistema político autoritário, ainda mais o Estado Novo, que pretendia tornar-se totalitário, pretende instituir uma identidade fixa” (DE DECCA, 2006, p. 5).

De fato, como sublinha Berenice Cavalcanti, e conforme observado em seção anterior deste Capítulo, Holanda partiu de clichês sobre o povo do Brasil, formulados/endossados por estrangeiros, e convenientes a um governo cujos discursos fixavam um tom panegírico/nacional, homogeneizador e nivelador de uma população brasileira em transformação, e ansiosa por transformar-se. Para formular seu conceito de "homem cordial", de fato Holanda partiu das - ditas tipicamente brasileiras - hospitalidade, generosidade, lhaneza no trato (CAVALCANTI, p. 143).

Entretanto me parece consensual - e a isso me dediquei na seção anterior deste Capítulo - que embora Holanda começasse Raízes abordando esse comportamento afável, comum a muitos dos brasileiros, logo partiu a propor que, a seu ver, tal proceder correspondia a uma "máscara" vestida, mais do que uma tendência observável todo o tempo. Parece-me consensual, nesse sentido, que o "homem cordial" foi elaborado também como forma de avaliar a dimensão de nossos mais característicos problemas sociais e organizacionais - tais como: o desrespeito às leis objetivas, a tendência à permissividade no que diz respeito a líderes fortes e carismáticos, a incompreensão dos limites entre o público e o privado. No que tange a todos esses pontos, pode-se perguntar: Holanda não estaria justamente se referindo, criticamente, ao comportamento do ditador então em exercício, e seus apoiadores?

Diversos intérpretes têm defendido, então, que Raízes não foi de fato elaborado a serviço do regime instaurado com a dita "Revolução de 1930", e sim em razão de uma grande 
angústia e incerteza, sentida desde então, por Holanda. Efetivamente, outras passagens da mencionada palestra, datada de 1967, reiteram isso: "Publicado o livro em 1936, quando andava em maré alta a pregação do integralismo, oferecia ele, ao contrário, uma denúncia inequívoca do fascismo, tanto em suas manifestações europeias como na variante indígena" (HOLANDA, 2008, p. 619).

A ex-aluna de Holanda, Maria Odila Leite da Silva Dias, assegura, nesse sentido: "Esta é talvez uma das mensagens mais fortes da referida obra: mostrar o limite do projeto do Estado-nação elitista e o problema da cidadania (...). [Em Raízes] ele critica muito as gerações que o antecederam e a sua, a do Estado Novo, por essa ideia autoritária” (DIAS, 2006, p. 7).

Consideremos, então, o segundo universo de questões, que a crítica a Raízes tende a replicar: a inutilidade acadêmica de suas ponderações, métodos, estilo.

A respeito, Piva, em estudo bastante mais recente, pontua:

pode parecer herético, mas não só os diagnósticos, mas muito do método de Holanda [incorre em] caracterizações generalizantes; argumentações exclusivamente retóricas; conclusões que nascem do pressuposto recémafirmado e não-comprovado; e utilização de casos contados por outrem, pequenos registros, textos soltos, exemplos isolados e impressões pessoais como peça de generalização e comprovação de largas hipóteses (PIVA, 2000, p. 177).

Dentre os principais críticos das proposições e métodos de Holanda, Bosi caracterizou Raízes como "ambicioso" e por isso "vulnerável"; recheado de hipóteses "temerárias" (BOSI, 2003, p. 263). Condenou sua "psicologia social antiquada", sua "tipologia humoral e contrastes retóricos" (BOSI, 2008, p. 36).

Mota, no livro de 1957, já criticara em Raízes o fato de ser "pouco científico" (Apud. RAMIREZ, 2011, p. 16). E Leite, vinte anos mais tarde, incluiu Raízes numa geração de livros cujas apreciações não poderiam ser muito levadas a sério, por não haver "critério de verificação" para elas, e por corresponderem a "expressões do ponto de vista pessoal do[s] escritor[es]" (Apud. PAIVA, 2000: 12).

Conforme Geraldo José de Paiva, Leite "não quer dizer [com isso] que não se possa perceber com objetividade características psicológicas de grupos: a dificuldade está em se ampliar a todo um povo [uma nacionalidade, tão caracteristicamente diversa] e, não raro, por longos períodos de sua existência" (PAIVA, 2000: 10). Leite, assim, teria considerado limitada a abrangência da interpretação nacional de Holanda: a seu ver, o conceito de "homem cordial" seria problemático por reduzido - tomado como representativo do "brasileiro", conteria em si apenas “descrição intuitiva do brasileiro de classe alta” (LEITE, p. 387). 
Embora reconheça que "a cordialidade tem para Sergio um sentido transitório", Everton Vieira Vargas pontuou, num mesmo sentido, que "o homem cordial é singular e, enquanto tal, oblitera a criação de espaços interpessoais onde o homem se revela como plural" (VARGAS, p. 219 e 217).

Na aqui já aludida palestra, na Escola Superior de Guerra, de 1967, o próprio Holanda atribuíra crítica semelhante a Raízes:

Mesmo admitindo que deva existir nas sociedades humanas algum fundo comum e permanente, [o bom historiador] saberá que só por meio de simplificações suficientemente ilusórias e traiçoeiras lhe seria dado reduzi-lo a um esquema suficientemente unitário. (...) Um ensaísta bem pode permitirse escolher, entre mil aspectos que lhe propõe o estudo do passado, aqueles que julgue os mais estimáveis ou simpáticos, e ainda os que o ajudem a bem armar suas teorias pessoais, quando as tenha. (...) Ora, nada mais longe das preocupações que hão de mover um historiador (HOLANDA, 2008, p. 619).

Em entrevista concedida à Veja na década de 1970, classificou como "aventura" a prática ensaística, voltada ao amplo-nacional; a "elucubrações, às vezes brilhantes, mas desvinculadas da realidade". E insistiu que era tempo de os intelectuais brasileiros se concentrarem em estudos mais empíricos ("rigorosos" e "exaustivos"), focados em recortes temporais e espaciais bem definidos (Apud. NICODEMO, p. 157-158). Em depoimento publicado na Folha de São Paulo, da mesma época, acrescentou que considerava ser "um pouco anti-histórico isso, de estabelecer uma espécie de categoria que não sai daquilo" (Apud. MARTINS, 2009, p. 145-146).

Temos visto, entretanto, que diversos intérpretes propõem que o "homem cordial" não correspondia, para Holanda, a uma definição de brasilidade fixa, fechada, terminada e determinante. O tipo "cordial”, descrito em Raízes, era uma ferramenta de análise, por contrastes, das relações, comportamentos e modos de ver do brasileiro.

E fato é que mesmo Mota apresenta Raízes como obra pioneira:

A historiografia da elite oligárquica empenhada na valorização dos feitos dos heróis da raça branca, representada pelo Instituto Histórico e Geográfico Brasileiro, vai ser contestada de maneira radical por um conjunto de autores [dentre os quais se inclui Holanda] que representarão os pontos de partida para o estabelecimento de novos parâmetros no conhecimento do Brasil e de seu passado (MOTA, 2008, p. 69).

Eu diria, então, que a opção por trabalhar tipos, como o "homem cordial", em uma análise histórica que conectava criticamente passado e presente, foi consideravelmente inovadora, num universo intelectual em que até então predominara a história evenementielle, as construções românticas e as especulações pautadas na composição racial do povo do Brasil. 
De maneira que, alguns anos depois da declaração acima, na introdução de Tentativas de mitologia, Holanda parece ter reconhecido, que, embora tivesse passado a considerar mais interessante a análise histórica de "fenômenos particulares", não deixava de ser fundamental entendê-los sempre "integrados em quadros amplos, onde ganhem nova dimensão e significado mais alto" (HOLANDA, 1979, p. 31).

Precisamente seguindo essa linha de raciocínio, Robert Wegner veio a sugerir que o tipo mais famoso do ensaio mais célebre de Holanda não reduzia o geral a um particular: continha em si um tensionamento claro, que serviria como combustível que dirige o olhar do leitor a um movimento de "constante abrir e fechar de olhos" - que amplia e enxuga as pupilas, que nos direciona para frente e para trás (WEGNER, 2006, p. 337).

Monteiro argumenta, nesse sentido, que Raízes "desenvolve uma percepção [...] que não mais se baseia exclusivamente, nos princípios (...) conclusivos do "caráter nacional"” (MONTEIRO, 2006, p. 316). Para esse pesquisador, "não parece ter sido (...), exatamente, o objetivo do [dito] historiador" "fixar fundamentalmente uma psicologia social, expressando um espírito coletivo e apontando, a partir dele, soluções para a assimilação de novas ideias e novos hábitos", ou "marcar a personalidade típica do brasileiro, (...) para, a partir dela, estabelecer linhas gerais de uma cultura brasileira" (Idem, p. 24).

Conforme De Decca, ademais, o "homem cordial" nos ajudaria, sim, a observar a população brasileira como caracteristicamente múltipla: "cordialidade", na definição de Holanda, seria observável em comportamentos e modos de entendimento das mais diversas classes sociais, dos mais distintos grupos (DE DECCA, 2006, p. 6).

Flavio Aguiar sugere, a somar, que em Raízes "Sergio Buarque não escreve só contra preconceitos; escreve também para que possamos superá-los, e prestar atenção em outras coisas, e nisto tem mãos de mestre" (AGUIAR, p. 71-71). Tal autor, destarte, nos lembra um ponto essencial: na análise de Holanda, se a cordialidade começara a ser gestada no período colonial, causando a impressão de que nossas experiências históricas se caracterizavam por marcantes continuidades, há latente a impressão de que, na modernidade, o "homem cordial" encontrava claras chances de desaparecer.

E mesmo Paiva, como intérprete de Leite, acredita que ele demonstrava, em sua medida, notar que Holanda, em Raízes, já "entrevia” que no decorrer dos anos poderia haver a "superação" daquela "psicologia" cordial; quer dizer, que Holanda entendia a psicologia nacional como fluida (PAIVA, 2000).

Além do mais, no mesmo texto da mencionada palestra de 1967 Holanda insistira que sua análise, em Raízes, por mais que carecesse de método rigoroso, encontrava-se "fundada 
largamente" em análises das mais diversas "formas de convívio, instituições, ideias" (HOLANDA, 2008, p. 619).

No que diz respeito às pesquisas mais recentes, importante pontuar que, segundo Wegner, "esse livro envolve sim rigor analítico e ampla pesquisa documental" (WEGNER, 2005: 97); e que, segundo Monteiro, Holanda buscou, ali, efetivamente, "guiar-se com segurança em meio ao emaranhado de fontes e de testemunhos (...), tentando ouvi-los com atenção" (MONTEIRO, 1999, p. 202).

Soma-se a isso o fato de que muitos intérpretes da obra de Holanda como um todo têm considerado que Raízes, justamente por ensaístico, permitiu maior liberdade para que se estabelecessem, amplamente, entendimentos-apostas, que ele viria a reavaliar e aprimorar, nas décadas seguintes.

Se tomarmos a palestra de 1967, que, como temos visto, corresponde a um largo exame de autocrítica, com foco em Raízes, mesmo ali o replicar de duas ideias essenciais que Holanda começou a desenvolver no clássico ensaio. Seriam elas: a compreensão do estudo do passado como forma de desmistificar verdades do presente; e a crítica às elites cultas, que se julgariam, ainda, descoladas da massa, e mais conhecedoras das necessidades de todos do que os populares, iletrados (HOLANDA, 2008, p. 637).

E mesmo Piva sublinha, de sua parte, outros conceitos, que ao que tudo indica foram abordados pela primeira vez, no Brasil, por Holanda, em Raízes, e retomados por seus críticos: "patrimonialismo", tão caro a Raymundo Faoro; e "burocracia", explorado por Caio Prado, e autores da chamada "teoria da dependência" (PIVA, 2000, p. 16).

Antes isso, afinal, Wegner propõe que, se Raízes não chega a ser considerado um "trabalho de historiador tout court", deve-se menos ao que nele falta do que ao que tem a mais (WEGNER, 2005, p. 97). Aguiar sugere que "décadas de academia e busca de um traço mais marcadamente objetivo no delineio da história nacional desacostumaram-nos desse esforço pertinaz de junto com o objeto iluminar o olhar que ilumina" (AGUIAR, p. 69). E Schwarcz, que "somos mais e mais especialistas em nossos próprios campos - cordiais até - e ninguém mais faz apostas desse calibre" (SCHWARCZ, 2008: 86).

Holanda parece ter-se dado conta disto, no final da década de 1970: de que seus críticos e ele mesmo exigiam de Raízes um padrão de análise um tanto alheio aos padrões disponíveis nos anos 1930. Como nos conta Monteiro, o autor de Raízes publicou, em 1978, o artigo Sobre a doença da historiografia, no qual criticava o livro de Mota, pelo "excesso de zelo com uma linguagem 'científica"'; e sobre o qual acrescentava: 
É como se um universo totalmente turbulento, em que os sentidos se compõem, se confrontam e contraditam, fosse 'domado' de forma completamente tirânica, para se chegar ao porto seguro da univocidade, ou da pretensa 'cientificidade' (MONTEIRO, 1999b: 150).

Para concluir, faz-se mister considerar que, se os críticos de Raízes estabeleceram suas análises muito em função das demandas de um tempo distinto ao de produção do livro, os intérpretes de hoje, necessariamente, também o fazem e devem buscar fazer de forma consciente. Na visão de Wegner, então, se hoje nos voltamos ao que há de positivo no ensaísmo de Holanda, é por estarmos cada vez mais atentos aos "perigos de burocratização e rotina que rondam as instituições" (WEGNER, 2005, p. 102).

No que diz respeito a esta Tese, em específico, eu diria que a estrutura ensaística de Holanda inspira a pensar em uma "História Intelectual" e uma "História dos Conceitos" que considerem: a atualidades de textos escritos no passado e inscritos numa tradição; a pluralidade de sentidos; e a importância política do estudo das ideias e modos de entender o nacional. 


\subsection{Considerações iniciais sobre Ramos e seu Perfil}

Como apontado na Introdução, o objetivo deste Capítulo é apresentar, didaticamente, cada um dos autores dos clássicos selecionados para análise. Nesta primeira seção, me dedico a desenhar esquematicamente a trajetória de Ramos, até a composição de El perfil, apontando algumas questões básicas, a serem retomadas, tais como: experiências profissionais, diálogos intelectuais, aspectos teóricos do referido ensaio, e também metodológicos.

Na próxima seção, concentro-me no conceito formulado por Ramos, em El perfil, para análise do mexicano de princípios do século $\mathrm{XX}$, que vem sendo considerado o conceito ali mais importante de sua obra: o "pelado".

E, na sequencia, na terceira seção deste Capítulo, voltarei a tais questões - teoria, metodologia e conceitos-chaves -, observando-as a partir do olhar dos principais críticos Ramos, sobretudo de sua fase como ensaísta.

Samuel Ramos nasceu em 1897, na pequena cidade de Zitácuaro, estado de Michoacán. Ainda criança mudou-se para a capital Morelia e, depois da morte do pai, já adolescente, para a capital do país.

No Distrito Federal a partir de 1916, Ramos seguiu estudando Medicina, mas pouco a pouco se descobriu sobretudo interessado em questões filosóficas, e abandonou a Escuela Médico Militar em 1919. Ao longo das décadas de 1920 e 1930 fez-se professor de importantes instituições de ensino, a começar pela Escuela Nacional Preparatória. Chegou a trabalhar para a Secretaría de Educación Pública do governo federal, e estampou críticas culturais em respeitados periódicos.

Seu biógrafo mais famoso, Juan Hernández Luna, lembra ainda que nos anos 1940 Ramos foi diretor da Facultad de Filosofia y Letras e fundou a cátedra de História da Filosofia Mexicana (HERNÁNDEZ LUNA, 1982, p. 102).

Conquistou, destarte, grande reconhecimento, como um dos mais importantes intelectuais mexicanos do século XX. Contudo, como observei na Introdução, especificamente seu Perfil tem sido pouco lido em seu próprio país, e segue desconhecido no nosso.

Deve-se pôr em destaque, então, que, embora Ramos fosse quinze anos mais velho, ele e Holanda viveram experiências de vida parecidas: se mudaram para a capital de seus respectivos países ainda muito jovens, cursaram faculdades que não correspondiam às carreiras pelas quais se tornariam famosos, e se formaram intelectualmente entre as editorias e redações de jornais e revistas. 
Tanto Ramos como Holanda, além disso, ao escreverem seus ensaios mais famosos não eram ainda os especialistas que seriam em seus livros posteriores - Ramos, na área de Filosofia; Holanda, em pesquisas de História. El perfil e Raízes foram, portanto, na trajetória intelectual de seus autores, espaços de exercício reflexivo, solto, sem arestas acadêmicas com os problemas e vantagens daí decorrentes.

As reflexões contidas em $\mathrm{El}$ perfil, sobre a realidade sociopolítica contemporânea de México, começaram a ser publicadas por Ramos em forma de artigos, em revistas literárias. Foram editadas pela primeira vez, juntas, pela Imprenta Mundial, em meados da década de 1930. Era um livrinho de 180 páginas, que contaba com sete capítulos: La imitación de Europa en el siglo XIX, La influéncia de Francia en el siglo XIX, Psicoanálisis del mexicano, La cultura criolla, El abandono de la cultura en México, El perfil de la cultura mexicana, El perfil del hombre.

Tinha mais ou menos o mesmo número de seções de Raízes, mas equivalia, em páginas, a um conjunto consideravelmente menos.

É verdade que o livro não teve tanta repercussão, entre os leitores mexicanos, quanto haviam tido os artigos já lançados, em separado (mesmo que a recepção desses tenha sido em grande parte crítica/negativa). Ainda assim, diferentemente de Raízes, uma segunda edição de El perfil veio a público já em 1938, com a adição de um mais capítulo: El indígena y la civilización (ADIB, p. 133).

El perfil era uma análise do mexicano e do México de princípios do século XX, se enquadrando, conforme o autor, no campo da "Filosofia da cultura" (RAMOS, p. 96). Mas, afinal, o que Ramos entendia por "cultura"? Partindo de tal rótulo, podemos admitir algumas informações sobre as concepções teóricas que embasaram sua análise.

A noção de "cultura" constante nas páginas de El perfil é bastante complexa. Primeiro, Ramos (Ibidem) propôs uma definição antropológica, comum aos historiadores de hoje: cultura como "modo de ser del hombre"; expressa não somente em "obras espirituales", mas "también en los más humildes actos del hombre, como la comida, la conversación, el amor etcétera" (Idem, p. 115). De fato, para apresentar seus entendimentos acerca do mexicano, ele recorreu a descrições de hábitos da elite dita "culta", mas também de hábitos do cotidiano de todo homem do México; descreveu, por exemplo, modos de falar, de se expressar, do mexicano rico e pobre.

Capítulos adiante, porém, Ramos nos confunde: criticou o desprestígio dos intelectuais e dos estudos universitários no México, criticou a educação mais técnica e prática promovida então pelo governo mexicano, e falou, logo, em “abandono de la cultura en México". Ele quis 
com isso dizer que se processava, afinal, em sua época, não o abandonando de um modo de ser do mexicano, da cultura mexicana como um todo; e sim o abandono da produção humanística de conhecimentos por parte de uma elite. Cultura, nessa passagem de sua obra, perde, então, subitamente, a ampla dimensão antropológica (Idem, p. 139).

O fato é, porém, que, como o próprio Ramos informava, a expressão ali empregada "abandono de la cultura" - fora tomada de uma conferência apresentada pelo filósofo alemão Ernest Robert Curtius no ano de 1932. Segundo Ramos, assim, tal como Curtius, a ideia não era defender a importância de uma cultura "superior", separada da realidade. A ideia era, mais precisamente, defender que não se contemplava, então, no México, a cultura em um sentido rico (que embora obviamente incluiria a cultura dita "superior", não se restringiria a ela); que no México os procederes tendiam, cada vez mais, a se pautar em simples reprodução, ou cumprimento de padrões pré-determinados, sem questionamento.

Daí que Ramos assegurasse, logo em seguida: "no queremos ni una vida sin cultura, ni uma cultura sin vida"; querendo dizer: nem o que estava posto em México, à época, nem a predominância de uma concepção elitista de saber e de criar. O que ele desejava era, melhor, "una cultura viviente" (Idem, p. 146).

Aqui cabe, ainda, abordar, para além da definição do conceito de "cultura", por Ramos, a definição do conceito de "cultura mexicana". Ora, Ramos demonstrava não estar seguro se ela existia, ou sobre como ela seria. Se por um lado destacava o hábito do mimetismo, de os mexicanos costumarem imitar culturas estrangeiras, trabalhava a hipótese de que haveria continuidades, nos procederes e modos de entendimento, ao longo da história nacional do México.

Essa insegurança, pontuo, não está nas entrelinhas de El perfil, e sim bastante clara, em inúmeras passagens, desde as primeiras páginas do livro. De maneira que, se ele se dispunha a trabalhar um "perfil" do mexicano, tinha em vista tal problema, e o sublinhava logo do primeiro capítulo: "Prescindamos por un momento de averiguar si la 'cultura mexicana' tiene uma realidad o no, y dediquémonos a pensar cómo sería dicha cultura en caso de existir" (Idem, 97). A seu ver a não existência uma concepção fechada para "cultura mexicana" era fato, a ser explorado e não solucionado: "Lo mejor, para no equivocarse, es considerar que no existe ningún modelo de lo mexicano, y obrar sin prejuícios, atentos solamente a identificar los movimientos que nacen espontaneamente de nuestro interior" (Idem, 151).

Ademais, consideremos que em El perfil Ramos tratou de realizações e do comportamento de sua gente, e da organização social e política de sua nação como não 
"naturais". Para ele, "hasta hoy la biología de nuestra raza no ha encontrado ningún dato para suponer que este afectada por alguna decadencia orgánica o funcional” (Idem, p. 109).

Ramos percebia os problemas do mexicano e do México como elaborações históricas. Em El perfil ele trabalhava, pois: descrições do processo de urbanização e tecnificação dos meios de produção em seu país; referências à ascensão das classes médias urbanas; diálogos com o estrangeiro, e o imperialismo europeu e estadunidense. Mas considerava também que todas essas transformações, condizentes com a dinâmica universal da modernidade, traziam continuidades em relação à história colonial mexicana, e assim ressaltavam peculiaridades do mexicano e do México - um "mismo fondo espiritual” repetindo-se (Idem, p. 108).

Como ele analisou essas continuidades? Começaria apontando o que ele não fez, embora fosse bastante comum em sua época.

Por interessar-se por pela dita "cultura vivente", elaborada através dos séculos, sempre em transformação, e expressão de constantes notáveis nas relações entre os mais distintos grupos sociais, Ramos se afastou de modelos tradicionais de abordagem da História, mais factuais, particularistas, e interessados em "grandes nomes". Afastou-se, também, das teorias raciais, e também de tendências românticas, de abordagem do ser nacional, no México.

El perfil é um ensaio; e, como tal, apresenta reflexões mais ou menos soltas. Mas Ramos não desenvolveu sua análise da modernidade mexicana e da História Nacional do México sem método.

Outro importante biógrafo de Ramos, Raul Arreola Cortes, se refere a um dado diálogo entre Ramos, em El perfil, e o filósofo espanhol José Ortega y Gasset; sugere que a famosa máxima ortegiana, "yo soy yo y mi circunstáncia”, teria ajudado Ramos a fundamentar sua visão historicista. E lembra: já em 1922 o ensaísta mexicano oficializara tal filiação, num artigo publicando na revista Hoy - Ortega y Gasset y la América Española (ARREOLA, p. 121).

Entretanto, é preciso fazer constar que Ramos não chegou a citar Ortega na primeira edição de $E l$ perfil. A referência ao espanhol aparece, claramente, apenas em uma edição bem posterior do livro; e, ademais, ainda assim Ramos considerou, de Ortega, conceitos outros, que não o de "circunstáncia".

Devemos avaliar, então, outra possível contribuição de Ortega y Gasset, para a composição da estrutura metodológica de El perfil. Naquela primeira metade do século XX esse filósofo espanhol editou a Revista Ocidente, que circulou pela Europa e pela América Latina, e por meio da qual muitos leitores hispanohablantes de nosso continente, dentre os quais Ramos, puderam acessar a vanguarda do pensamento europeu; com destaque para as 
reflexões que vinham sendo produzidas na Europa Central, através das fronteiras de Alemanha, Áustria e Suíça.

Ora, em 1927, sendo enviado pela Secretaría de Relaciones Exteriores mexicana à Rússia, para as comemorações do aniversário de dez anos da Revolução Socialista, Ramos agarrou a possibilidade de, estando na Europa, percorrer vários países; e estabelecer contato com vários pensadores que ele conhecia de forma indireta, e lhe interessavam profundamente. Foi, de Moscou, às cidades alemãs Colônia e Frankfurt, em busca de Max Scheler, a Viena, em busca de expoentes da Psicanálise, e a Paris, onde se encantou com as aulas do russo Georges Gurvitch, sobre os alemães Edmund Husserl, Martin Heidegger, Max Scheler, e o russo neokantista residente na Alemanha Nikolai Hartmann (HERNÁNDEZ LUNA, p. 183, 184 e 191).

Desses autores, ganham destaque no texto de El perfil as referências aos discípulos de Sigmund Freud.

Antes considerar, porém, a influência deles sobre Ramos, especificamente na composição do dito ensaio, cabe uma antecipação: não parece psicanalítica a iniciativa de se voltar ao passado para melhor se compreender o presente? A preocupação com a análise do México Colonial, por Ramos, tão comum entre seus contemporâneos e conterrâneos, parece ter encontrado eco na preocupação dos psicólogos/psicanalistas austríacos e suíços, da época, com a análise da infância do paciente. O discurso de Ramos, logo, se preenche de chavões da nascente Psicanálise: ele afirmava, tal como um analista, que era preciso buscar compreender "causas ocultas" de determinados comportamentos, para transformá-los (RAMOS, p. 117); ele afirmava, tal como um analista, que se poderia compreender melhor as falsificações e distorções de verdades, quando as observamos com um olhar deslocado (Idem, p. 100). Ele apresentava, ainda, nesse sentido, uma bela metáfora, que merece ser aqui transcrita: "Los fantasmas son seres nocturnos que se desvanecen con sólo exponerles a la luz del dia" (Idem, p. 127).

Senão, vejamos: o autor que Ramos menciona como sua principal referência teóricometodológica, no primeiro texto de El perfil, é o psicólogo austríaco Alfred Adler, por sua teoria do "complexo de inferioridade" (Idem, p. 117-118). Sobre o trabalho do também psicólogo, mas suíço, Carl Gustav Jung, faz menções, ainda que um tanto aleatórias (Idem, p. 133 e 153); num prefácio somado a edições posteriores de El perfil, porém, nosso autor declararia haver tomado contato com Jung muitos anos antes, e colocaria ênfase no conceito jungiano de "introversão" (Idem, p. 91). 
Nessa introdução, e apenas então, Ramos viria a apresentar, afinal, de forma sistemática, sua interpretação sobre as análises de Adler e Jung, e as amarraria, numa definição articulada. Cruzando a noção de "sentimento de inferioridade" e de "introversão", afirmaria, ali, afinal, que com esses dois ex-discípulos de Sigmund Freud teria aprendido que

existe un tipo psicológico de hombres, cuyo propósito fundamental en la vida es hacer prevalecer su 'yo'. Se comprende que el instinto que predomina en tales sujetos es el instinto de poder. El amor, el dinero, la cultura, son ante él simples medios para hacer valer su personalidad (Idem, p. 91).

Teria sido, então, à luz de tais concepções que Ramos concebeu, na década de 1930, o tipo "pelado": "la expresión más elementar y bien dibujada del carácter nacional" mexicano (Idem, p. 119); o "pelado", que se assemelharia a "un animal que se entrega a pantomimas de ferocidad para asustar a los demás, haciéndole creer que es más fuerte y decidido" (Idem, p. 121). Dediquemos, pois, a próxima seção a refletir sobre tal termo e definições aplicáveis a ele.

Antes de concluirmos essa seção, porém, creio prudente pincelar alguns detalhes importantes, sobre a metodologia trabalhada por Ramos em El perfil.

Ora, para Ramos as análises de Adler e Jung, sobre as psicologias individuais, teriam servido como referência para que pensasse a psicologia coletiva mexicana: porque aqueles estudiosos trabalharam com conceitos - de complexo de inferioridade, e introversão - que ele considerou interessantes no contraste com o modo de ser do mexicano, em geral; e também porque eles trabalharam com a formulação de "tipos", ferramentas de análise, e contraste, e não com categorias classificatórias dos estilos de vida, de pensamento, de proceder - o que permitiu a Ramos fugir das análises "essencialistas" e a-históricas dos intelectuais ufanistas e das teorias raciais, em voga na época, em seu país.

Eis um vasto campo a ser explorado em estudos posteriores, e que, por questão de tempo e recorte, não desenvolvo nesta Tese. Uma possibilidade que, sobretudo em outra análise comparativa, entre Holanda e Ramos, há de resultar profícua, já que como vimos, também Raízes flerta com a Psicanálise. Além disso, a considero interessante, por fim, porque também há poucos estudos que contraponham o ensaio brasileiro com as especulações de Freud, companheiros e discípulos.

Leopoldo Waizbort e André Goldfeder apontam, como leitura psicanalítica de Holanda, para a composição de Raízes, Werner Sombart. Conforme Waizbort e Goldfeder, tanto Holanda quanto Sombart abordam, em suas análises acerca da modernidade, uma dimensão psicológica e uma dimensão social (WAIZBORT; GOLDFEDER, 2009, p. 22). 
É possível que El perfil, como estudo psicossociológico, do México contemporâneo, também apresentasse pontos em comum com textos de Sombart? Cabe averiguar.

Aí então caberia considerar, também, num estudo futuro, ainda, a importância das proposições de Ludwig Klages.

Klages publicou, em 1929, na Alemanha, o livro Die Grundlagen der Charakter kunde (algo como "Os fundamentos da caracteriologia”, ou "A ciência da caracteriologia”, em tradução livre). Klages considerava ali o comportamento humano, em várias manifestações, como no modo de escrever, a caligrafia; identificava diferenças e repetições; e, a partir disso, elaborava tipos de caráter. Defendia, ainda, que o "espírito" se encarregaria, em nosso ser, de limitar potencialidades e necessidades "vitais", embora muito desse "vital" se revelasse, quando menos se dá conta. Veio, assim, a empregar o conceito de "repressão", celebrizado pelo pai da Psicanálise.

Essa preocupação com procederes mais triviais do homem, e a definição de tipos, não lembra as proposições de Ramos? Não lembra El perfil também tal preocupação com o que está oculto? Em que medida a noção de "repressão" de Klages, dialogou, ou não, com as noções de "complexo de inferioridade" e de "introversão", respectivamente expostas por Adler e Jung, discípulos de Freud?

No que diz respeito ao outro ensaio por mim trabalhado e possíveis aproximações entre ele e textos de Klages, há o registro de uma entrevista feita por Manuel Bandeira, com Holanda, logo quando esse retornou ao Brasil. Ali o poeta pernambucano fez constar o encanto do jovem ensaísta pelas proposições do aludido teórico alemão. Num mesmo sentido, é notável o fato de que "Os fundamentos da caracteriologia", como indiquei acima, foi publicado precisamente no ano em que Holanda encontrava-se na Alemanha.

Fato é que Holanda, em Tentativas de mitologia, negou qualquer presença das proposições de Klages, em Raízes: embora tivesse se interessado pelo mencionado teórico, pronto teria percebido que adotá-lo "seria voltar um pouco ao ambiente intelectual que quis deixar, deixando o Brasil” (HOLANDA, 1979, p. 30). Já Candido pontuou que Klages lidava com "caracteriologias duvidosas", ponto em que diferiria do autor de Raízes (CANDIDO, 1982, p. 7).

Tais proposições de Holanda e Candido são, contudo, bastante vagas. Holanda, de sua parte, não especificou, no referido texto e outros, o que é que efetivamente lhe incomodava em Klages. E Candido não tratou de declarar o que lhe parecia haver de mal na caracteriologia daquele autor alemão. 
Para finalizar, eu acrescentaria: além de considerar importante avaliar com pormenores contrastes metodológicos de El perfil e outros textos interessados em aspectos psicológicos, com os quais Holanda possa ter dialogado, quando escreveu Raízes, julgo interessante que estudos posteriores desdobrem possíveis diálogos entre o jovem Ramos e sociólogos, sobretudo alemães, que também trabalharam com tipologias.

Em que medida os tipos compostos, sobre os mexicanos, por Ramos se aproximam dos tipos propostos por Weber e Simmel? Eis uma pergunta que, para evitar especulações vazias, deixo, por enquanto, sem resposta.

Por agora, nesta Tese, me restrinjo tão somente à constatação de que Ramos optou por trabalhar a composição de "tipos" como ferramenta de análise psicológica e sociológica do homem do México; ferramenta não redutora, que desse conta de aspectos comportamentais, não essencializados, dinâmicos. E concedo foco ao tipo "pelado", acima aludido. Como ele foi definido e percebido? Como ele vem sendo analisado, pelos críticos? De que medida ele ajudava o dito ensaísta mexicano a melhor compreender as possibilidades e os alcances da revolução, em seu país? 


\subsection{Um conceito importante: 0 "pelado" mexicano}

Conforme já anunciado, esta seção se dedica ao considerar usos históricos, no México, do termo de "pelado".

Hoje, de fato, o dicionário da Real Academia Espanhola inclui, entre as definições para o verbete o "pelado", a seguinte: "pobre o de poco dinero", "persona de las capas sociales más bajas".

Decerto a palavra "pelado" já era comumente usada para designar os populares e miseráveis, no México letrado e iletrado, antes de ser fixada no texto de El perfil. Isso será retomado, ao longo desta Tese, quando forem abordadas obras de outros intelectuais da época.

Em La sombra del caudillo, uma novela de 1929 que também tinha como tema o México das primeiras décadas do século XX, a massa mexicana envolvida nas contendas ditas "revolucionárias" foi descrita como um coletivo de "pelados". Seu autor, Martín Luis Guzmán, efetivamente não chegou a empregar o referido termo, mas insistiu na caracterização da nudez: "hombres cuyas carnes se cubrían apenas con ropas de manta" (GUZMÁN, p. 80), com "pies descalzos", "pies desnudos - negros como el lodo" (Idem, p. 91), "semidesnudos" (Idem, p. 93), etc.

Em México Insurgiente, de 1913, o jornalista norte-americano John Reed, apresentou o líder revolucionário mexicano Pancho Villa como homem caracterizado por uma "linguagem vulgar", bastante típica dos cidadãos das "classes mais pobres", aos quais era comum, então, dizia Reed, chamar-se "pelados" (REED, p. 156).

O Museu de Caricatura, na Cidade do México, ademais, exibe muitas charges, publicadas em jornais mexicanos da primeira metade dos novecentos, nas quais figuram tipos designados como "pelados": rústicos, portando grandes sombreiros e roupas gastas, quase sempre enganados por personagens que vestem trajes finos, moda europeia. O jornal $E l$ universal, por exemplo, publicou tirinhas do desenhista Jesus Acosta Cabrera Dux, sobre o personagem El Chupamirto, que tinha como alcunha "el peladito". O tipo esboçado nesses cartoons, que conquistaram repercussão, era um rústico morador da cidade (mais especificamente do bairro de Tepito), suposta vítima do sistema, cujo propósito de vida era trabalhar pouco, e sempre se dar bem a custa dos outros, o que lhe conferia um ar de divertida ironia (DÍAZ, 2011).

Bom lembrar também que, no ano de 1936 o ator Mario Moreno Reyes levava para o cinema, na película No te engañes corazón, o personagem "Cantinflas, el peladito": tratava-se de um cidadão de comportamento um tanto rústico, mas cujas aventuras se passavam na 
Cidade do México; cidadão maltrapilho, que falava um espanhol incompreensível, egoísta, preguiçoso e pouco inteligente, mas que se adaptava às circunstâncias e sobrevivia aos infortúnios (Ibidem).

Para melhor avaliar em que medida a visão de Ramos dialogava e/ou rompia com essas, faz-se mister voltarmo-nos às definições propostas por ele em El perfil, e nesta tese há pouco transcritas: ali, o "pelado" foi proposto como "la expresión más elementar y bien dibujada del carácter nacional" mexicano (RAMOS, p. 119); como um homem que se assemelha a "un animal que se entrega a pantomimas de ferocidad para asustar a los demás, haciéndole creer que es más fuerte y decidido" (Idem, p. 121). E, eu acrescentaria: como alguém cujos “más íntimos resortes” não podem “esconder” nada (Idem, p. 120).

A partir de então, creio, devemos considerar, primeiramente, que na interpretação de Ramos o "pelado", como conceito, revestiu-se de maior complexidade. Não mais apenas se referia ao bárbaro, ao bruto, ao pobre, ao proletário, maltrapilho. Não apenas se referia a setores sociais, do México, que possuiriam uma linguagem bem específica, marcada por gestos brutos e vocábulos chulos; pela falta de polidez. Envolveria todos os grupos, toda a sociedade.

Em segundo lugar, é preciso ter em mente que a "nudez" do pelado de Ramos equivalia a uma complexa metáfora, e implicaria, mais do que uma aparência, um padrão de reações. O mexicano seria tipicamente, ao ver de desse autor, vulnerável. Mas isso não decorreria, para ele, tão somente do fato do mexicano não possuir recursos materiais - roupas, moradia -, que lhe garantissem segurança física, e sim do fato de nutrir um notável senso de inferioridade - algo interno e primordial. Essa vulnerabilidade iria muito além de questões financeiras; seria, sobretudo, psicológica.

Em recente artigo, Hector Zagal sublinha também no "pelado" de Ramos, não a condição de miserável; mas o senso de inferioridade. Para ese filósofo e reputado comentarista político mexicano, "la intuición fundamental de Ramos [aliás] parece acertada. Pasemos del discurso del fútbol a la economía, la política y, en general, a la vida social. El sentimiento de que este país ha fracasado se cuela por todas las rendijas" (ZAGAL, 2010, p. 2).

Ao ver de Ramos, porém, do sentimento de inferioridade e vulnerabilidade, do mexicano, na década de 1930 decorria não uma explícita, nos discursos, conformação do fracasso. Decorriam comportamentos aparentemente contraditórios, como a rispidez, a afronta, a ousadia do enfrentamento do outro, a autoafirmação violenta, por parte de um ser que se sente, no mais íntimo, frágil e exposto. Tal como o rei nu da fábula, portanto, pobre ou 
rico o mexicano não notaria que suas "vergonhas" estariam sempre descobertas, e insistiria numa vida de mentiras degradantes e óbvias.

Cabe aqui pontuar que, em Raízes, referindo-se ao "homem cordial", Holanda havia proposto uma metáfora físico-corporal que se aproximava bastante dessa metáfora do "pelado", proposta por Ramos. Havia sugerido: "Como Plotino de Alexandria, que tinha vergonha do próprio corpo, acabaríamos, assim, por esquecer os fatos prosaicos que fazem a verdadeira trama da existência diária, para nos dedicarmos a motivos mais nobilitantes" (HOLANDA, 1999, p. 163). Do que se depreende: o "homem cordial" brasileiro desejaria ascender a um universo superior de procederes que não condiriam com a realidade nacional, da mesma maneira que o "pelado" mexicano vestiria a uma armadura transparente, que não cumpria função de proteger, aquecer, encantar.

A menção de Octavio Paz, em El laberinto de la soledad, de 1950, acerca do "pelado" de Ramos, sublinha esse como o aspecto mais importante do conceito mais importante formulado em El perfil: para Paz, "não só a maior parte de suas observações ainda são válidas, como também a ideia central que o inspira continua sendo verdadeira: o mexicano é um ser que quando se expressa se esconde; suas palavras e seus gestos são quase sempre máscaras" (PAZ, p. 144).

Cabe, em terceiro lugar, pois, demarcar que, para Ramos, esse sentimento de inferioridade não era "natural", nem correspondia a uma essência do mexicano. O mexicano havia aprendido a se sentir inferior, porque historicamente vinha se comparando, geração após geração, a elementos estrangeiros e estranhos; porque vinha se avaliando a partir de padrões comportamentais e morais alheios aos seus. O mexicano, dizia Ramos, em vão tentava seguir roteiros formulados em outros países, e para outras conjunturas, e, se ia acostumando a se decepcionar a cada insistente tentativa e inevitável erro. Tornando-se, assim, acabrunhado, triste, e sentindo-se inferior; e se dispondo muito pouco a observar a si próprio, e a desejar, corajosamente, traçar seu próprio destino, criativamente (RAMOS, c. 3).

Pode-se dizer que nisso a análise de Ramos se afastava, consideravelmente, da análise de Holanda. Que Ramos desenhou a psicologia coletiva, no México, a partir de um modo generalizado de se observar o todo, no decorrer da história do grupo; enquanto Holanda desenhou a psicologia coletiva, no Brasil, a partir de comportamentos repetitivos, iguais, estabelecidos, concomitantemente, e repetidamente, através do tempo, como resposta a uma situação material, dada e continuada. A comparação com o estrangeiro definia o mexicano de El perfil; a vivência num universo próprio, sem leis, definiria o brasileiro de Raízes. 
Contudo, creio que nem Ramos restringe sua argumentação a tais considerações; e nem Holanda, as dele. Podemos notar em El perfil que a violência de cada dia, como resposta às dificuldades das constantes guerras, condenaria o mexicano a uma eterna sensação de instabilidade (Idem, p. 67). E podemos notar das páginas de Raízes que a bondade surge, no Brasil, como uma forma de ser bem aceito pelos estrangeiros, que o julgam, e o fazem julgarse, sempre, inferior.

Em quarto lugar deve-se considerar que o mexicano em geral, conforme a crítica de $E l$ perfil, se concentraria nas diferenças, para afastar-se dos outros; dado que possivelmente o diferenciaria do brasileiro em geral, conforme a crítica de Holanda.

A meu ver, porém, tal distinção não se estabelece. Conforme a interpretação de Holanda, o brasileiro viveria no outro, para fugir de si mesmo. Se dissolveria num todo, amorfo, sem marcar presença, sem demarcar um sentido de viver próprio, minimamente solidário.

Como última questão, a respeito, eu diria que o "pelado" de Ramos possui uma dimensão passional, afetiva e irracional a ser investigada: uma dimensão talvez latente, talvez apenas estereotipada, mas necessariamente, ao ver do autor de El perfil, inconsciente. O problema do mexicano comum, para esse autor, não era tanto ser violento, ou pobre, ou vulgar; ou mesmo sentir-se inferior. O problema é que todas essas fórmulas e procederes ocorriam sem maiores reflexões, e conforme os ditames impulsivos e doentios de um subconsciente mal formado. Isso, afinal, precisava ser prontamente considerado, e revertido; isso, afinal, era o que a moderna psicologia, os psicanalistas, lhe ajudavam a observar, e a desejar mudar (Ibidem).

Importante aqui sublinhar que há leitores de El perfil que consideram o "pelado" como uma maneira de adocicar o comportamento violento do mexicano; de convertê-lo em pitoresco, e, portanto, como um parâmetro de identificação acrítica entre os cidadãos do México, daquelas primeiras décadas dos novecentos.

Roger Bartra, em La jaula de la melancolia, de 1996, é um bom exemplo. Para ele, o "lépero" - figura comum na literatura hispânica, do período colonial, proposta como "pozo sin fundo de vícios, de animalidad y de atavismos sanguinarios" (BARTRA, p. 46) - teria sido convertido por Ramos, em "pelado" - ser possuidor de uma "agressiva emotividad", capaz de resistir a "imersión em la fria tecnologia" e aos "aires de la sociedad industrial moderna" (Idem, p. 124).

Ora, até onde temos visto, tais apreciações não condizem nem com as concepções nãoufanistas de Ramos, sobre a cultura mexicana; nem com a metodologia de formulação de 
tipos, de El perfil, que escaparia aos enquadramentos e buscaria criticar mais do que enquadrar. Por fim, estaria em descompasso com as definições do conceito, propostas por Ramos, e por mim transcritas - as quais contém um claro tom de lamento, e embutem um claro desejo de mudança.

Carlos Monsiváis destaca, a respeito, que a opção pelo termo no diminutivo "peladito" -, no cartoon e no cinema, contrastava com a opção de Ramos por dizer, simplesmente, "pelado". Para esse célebre intelectual mexicano, isso denotava que nos jornais e no filme o personagem correspondia a um bárbaro inofensivo, por quem se podia sentir pena, e que portanto levava ao riso; enquanto em El perfil tratava-se de um elemento com o qual não se podia identificar sem certo constrangimento (MONSIVÁIS, 2004, p. 93).

A título de conclusão desta seção eu diria, então, que embora o termo não tenha sido uma criação de Ramos, e embora ele o tenha empregado com um significado próprio e diverso daquele compartilhado por muitos de seus contemporâneos, fato é que El perfil e o "pelado" seguiram, através de décadas, sendo quase invariavelmente referidos, quando se pensou ou se desejou representar o mexicano comum. Por isso se faz indispensável uma revisão crítica das leituras e significações propostas e impostas sobre tal livro; objetivo ao qual se dedica a seguinte seção. 


\subsection{Leituras de $E l$ perfil}

Esta seção se dedica a avaliar as críticas mais importantes, propostas às configurações de El perfil.

Para dar início, creio ser interessante transcrever as ponderações de Ruben Salazar Mallén, sobre o clássico ensaio do amigo Samuel Ramos: "Fue un horrible fracaso: hubo indiferencia, comentários en contra y hasta burlas feroces. Un total fracaso, sí; pero Ramos había abierto una brecha en México, a pesar de la incomprensión inicial. En efecto, quince años después se desató arrolladoramente la necesidad de pensar a México y los mexicanos, de desentrañar su ser, y todo el pensamiento a este respecto procede o es desarrollo de las ideas ya expuestas por Ramos" (SALAZAR MALLÉN, 1960).

Quinze anos depois, ou seja, a década de 1950. Avaliemos, pois, algumas condições que teriam permitido esse resgate da obra de Ramos; e em que termos.

O historiador mexicanista francês Raphaële Plu Jenvrin analisa os discursos proferidos pelo presidente mexicano Miguel de Alemán, entre 1946 e 1952, e destaca alguns termos repetidamente empregados, quando em referência ao passado do país: "complejos", "amargura", "desconfianza en si mismo", "tragédia", "fatalismo", "condena". Bem mais suave foi, por outro lado, o vocabulário empregado quando em referência ao presente e ao futuro do México; enfocava-se, aí, sobretudo, a estabilidade política e financeira, que garantiriam aos mexicanos tranquilidade para viver, trabalhar, consumir, ter esperança; do que adviria um novo parâmetro de identificação nacional: o sorriso franco, redentor. "La mexicanidad es el espejo de México perfilado por el semblante del mexicano que está comenzando a sonreír con la misma franqueza que antes ponía en el rostro fiero o amargo, trágico o resignado", dizia a propaganda do governo (Apud. JENVRIN, 2005, p. 5-6).

Alemán era o primeiro presidente civil, em muitos anos, e fatores internos e externos, como a Segunda Guerra Mundial, lhe permitiram promover crescimento econômico, e prestígio internacional, para aquele país.

Para além do governo, ou a ele vinculado, então, fato é que cidadãos comuns e intelectuais se voltaram, no México, a investir na revisão das perspectivas comuns sobre o homem e o modo de ser mexicanos. O fizeram, é claro, de forma distinta do que havia ocorrido na década de 1930, quer dizer, sob marcante otimismo. Para o profesor Tzvi Medin, "la vivencia de la náusea y la muerte pueden ser propias del hombre europeo luego de la hecatombe pero estaban lejanas, muy lejanas de lo mexicano de ese momento" (MEDIN, 1990, p. II). 
Fundamental destacar, aqui, que nessa conjuntura se inscreve a publicação de uma nova edição de El perfil. Sim, uma terceira edição do livro de Ramos veio a público em 1951, pela Editora Espasa-Calpe, contanto com consideráveis acréscimos: um célebre prólogo, escrito pelo autor; comentários críticos, redigidos pelo filósofo espanhol José Gaos, e sete novos capítulos: La educación y el sentimiento de inferioridad, La pasión y el interés, Juventud utopista, La lucha de las generaciones, Cómo orientar nuestro pensamiento, La pedantería, Justo Sierra y la evolución política de México. ${ }^{8}$ Houve, ainda, a exclusão definitiva do capítulo sobre os índios nativos.

Mas, no que diz respeito ao texto do ensaio original, não houve grandes alterações.

Devemos considerar, porém, que, conforme indicam depoimentos de Ramos, à época, se operaram, na maneira desse autor perceber o México, algumas mudanças importantes. Em 1958, a renomada escritora mexicana Elena Poniatowska publicou uma breve entrevista com ele, a respeito. Tal entrevista, guardada em recorte pela viúva do autor de El perfil, Adela Palácios, consta hoje no arquivo doado ao Instituto de Investigações Filosóficas da UNAM, sem maiores referências. Nela, Ramos declarava não compreender mais o "pelado" e seu sentimento de inferioridade como representativos do mexicano; o "pelado" teria sido um referencial conceitual interessante para se pensar o mexicano na década de 1930, mas a seu ver, desde então, muito havia mudado na psicologia nacional (Apud. HURTADO, 2005).

Quando abordei as interpretações mais clássicas de Raízes, apontei que, dentre seus críticos mais importantes, estaria o próprio Holanda; disse, então, que o autor desse tão célebre ensaio brasileiro, anos depois, revelou-se em desacordo com alguns pontos que ali havia proposto, desenvolvido, estruturado. E fato é que Ramos, com o passar do tempo, também veio a propor uma série críticas a El perfil.

Há, porém, aqui, entre o intelectual brasileiro e o intelectual mexicano por mim analisados, uma diferença que deve ser destacada. Holanda rejeitou Raízes como um todo. Mas, se na década de 1950 Ramos afirmou que o conceito de "pelado" não mais era interessante, se se buscava entender o cidadão do México, seguiu firmemente defendendo a importância de sempre se estabelecer parâmetros de reflexão filosófica a partir do nacional, tal qual fizera em El perfil.

Junto à terceira edição de El perfil, publicou-se, na conjuntura apontada por Salazar Mallén, uma vasta bibliografia dedicada a pensar sobre a psicologia e o comportamento do

\footnotetext{
${ }^{8}$ Ainda que muitos autores tenham considerado que os novos capítulos quase não dialogavam/dialogam com os capítulos originais (Cf. ADIB, 1951, p. 133), o fato é que o livro assim seguiu sendo reimpresso pela editora da UNAM, nas Obras completas de Ramos, até 2005, quando deixou de ser publicado.
} 
homem do México. De minha parte, considero pouco seguro trabalhar a noção de "pioneirismo", até porque muitos pesquisadores têm, recentemente, destacado dívidas do autor de El perfil com outros intelectuais, que ele não cita em seu livro. ${ }^{9}$ Porém, é imprescindível ter em mente que, para o bem ou para o mal, o dito ensaio de Ramos se converteu em referência fundamental para todo intelectual interessado em entender o modo de pensar e de viver do mexicano.

A título de exemplo, aponto aqui algumas obras que são, nesse sentido, sempre lembradas: Isagoge sobre lo mexicano (1952), de César Garizurieta, Picardía mexicana (1960), de Armando Jiménez, Psicología del mexicano (1961), de Rogelio Díaz Guerrero, El estereotipo del mexicano: estudio psicosocial (1965), de María Luisa Rodríguez Sala, El Mexicano: psicología de su destructividad (1965), de Francisco González Pineda, El mexicano enano: un mal de nuestro tiempo (1966) e El mexicano, ciudadano de quinta (1969), ambos de Oscar Monroy Rivera, Psicología del mexicano: cultura y personalidad (1975), de Rogelio Díaz-Guerrero, El Mexicano, psicología de sus motivaciones (1978), de Santiago Ramírez, El mexicano: raíces de la mexicanidad (1983), de Antonio Oriol Anguera e Francisco Vargas Arreola, e, ainda, El mexicano: aspectos culturales y psicosociales (1982), de Raúl Bejár Navarro.

Dentre esses trabalhos, tiveram considerável projeção o aqui já mencionado $E l$ laberinto de la soledad (1950), de Octávio Paz; e textos do grupo de filósofos denominado Hiperión.

Ora, a dívida de Paz com Ramos chegou a ser denunciada, no México, na década de 1980, mas não teve ressonância, e se dissolveu com o passar dos anos. Alguns artigos que

\footnotetext{
${ }^{9}$ Nos anos 1950, Victor Adib se deslocara bastante no tempo e apontara como antecessor de Ramos o jesuíta Juan de Cárdenas, que viveu na transição do século XVI para o XVII (ADIB, p. 135), e cuja obra, conforme Uranga, correspondia a uma etapa inicial de uma dada "formación de nuestra consciéncia de nacionalidad" (URANGA, 1967, p. 479). Entretanto, uma contraposição clara entre as ponderações de Ramos e Cárdenas sobre o mexicano, creio, se está ainda por fazer.

Maria del Carmen Rovira Gaspar e seus discípulos, na UNAM, integrantes do Seminário Permanente de Filosofia Mexicana, têm trabalhado a possível referência de Ramos, sem que a tenha mencionado em El perfil, a Ezequiel A. Chavez, autor do artigo Ensayo sobre los rasgos distintivos de la sensibilidad como factor del carácter mexicano, publicado na Revista Positiva. Em 2004, sob orientação de Rovira, o licenciado Francisco Javier Pérez Romero explorou aproximações e afastamentos entre o texto de Ramos, de 1934, e esse, de 1901, na monografia El sentimiento de inferioridad del mexicano y la posibilidad de una cultura mexicana en 'El perfil del hombre y la cultura en México'. Ademais do contraste entre os dois autores ali consta, como anexo, inteiramente transcrito, o até então raro e pouco lido texto de Chávez (PÉRES, p. 96).

Raul Arreola, por fim, sugere a possibilidade de Ramos ter desenvolvido a tese do sentimento de inferioridade do mexicano, sob inspiração ou contato com o escritor David Herbert Lawrence. Lawrence publicou La serpiente emplumada a partir de uma viagem feita ao México no ano de 1924, na qual contou com Ramos em sua comitiva de recepção. Segundo Arreola, no livro lançado em 1926 o inglês se referia ao fato de os mexicanos da cidade facilmente se aborrecerem e se enraivecerem uns com os outros; e já explicava tal tendência como correspondente a um suposto "inferiority complex" (ARREOLA, p. 135).
} 
então se dedicaram a tal revisão foram compilados pela viúva de Ramos, e hoje constam na biblioteca do IIF da UNAM, podendo ser consultados. Em um deles, intitulado El plágio del león, de autoria de José Luis Ontiveros, acusa-se: "Paz se despachó a Ramos, con cuchara grande, clavando los dientes en sus ideas, arrancáncole pedazos de espíritu con la boca ensangrentada" (Apud. HURTADO, 2005). Noutro, intitulado Defensa de Samuel Ramos, de autoria de Ruben Salazar Mallén, lê-se: “Anda por ahí el libro de un 'bucanero’, un libro que se llama El laberinto de la soledad, que es una rapaz paráfrasis de El perfil del hombre y la cultura en México (...). El único mérito del 'bucanero' consiste en un estilo coruscante. Y claro está, el que pergeñó la obrilla procura por todos los medios que el nombre de Samuel Ramos sea olvidado, para que el saqueo no sea advertido" (Ibidem).

Contudo, a verdade é que El laberinto apresenta, sim, referências a El perfil. E elas são críticas, porém, afinal, bastante positivas.

Esse autor, mais jovem, pontua que há problemas na forma com que Ramos estrutura seus argumentos. Escreve:

Diz-se que El perfil, primeira tentativa séria de nos conhecer, padece de diversas limitações: o mexicano que suas páginas descrevem é um tipo isolado, e os instrumentos de que o filósofo se serve para penetrar a realidade - a teoria do ressentimento, mais como exposta por Adler do que por Scheler - talvez reduzam a significação de suas conclusões (PAZ, p. 142).

Logo no início de seu livro, entretanto, Paz afirmava que "basta passar a fronteira para, confusamente, fazer-se as mesmas perguntas que se fez Samuel Ramos” (Idem, p. 16).

Ele fazia notar que Ramos acertava na problematização e na tese, e por isso se convertera em um clássico; dizia: "seu livro continua sendo o único ponto de partida para nos conhecer", “a maior parte de suas observações ainda são válidas”, etc (Idem, p. 144).

Quanto ao grupo Hiperión, foi composto por alunos de Ramos e do já mencionado José Gaos, dentre os quais Abelardo Villegas, autor de La filosofía de lo mexicano (1960) ao qual me referirei por diversas vezes, ao longo desta Tese -, Emílio Uranga, autor de Ensayo de una ontología del mexicano (1949) e Análisis del ser mexicano (1952), Jorge Portilla, autor de La fenomenologia del relajo (1966), e aquele que em nosso país é o mais conhecido de todos, Leopoldo Zea, autor de Conciencia y posibilidad del mexicano (1952), e editor da coleção Mexico y lo mexicano, pela Porrua y Obregón.

A questão é que, no entretanto, diversos intérpretes têm considerado que Ramos e todos aqueles que o leram e a ele se referiram, a despeito de terem produzido em conjunturas diversas, trabalharam igualmente pela composição de uma identidade nacional una, em geral 
estereotipada, generalizadora, vulgar. Eis o que defende o historiador britânico Paul Gillingham, hoje às vésperas da publicação de livro sobre "fraude e identidad nacional en México": "Generaciones de intelectuales mexicanos, entre quienes destacan Manuel Gamio, Samuel Ramos y el propio Octavio Paz, se dedicaron con entusiasmo a la tarea de cazar y captar la identidad nacional" (GILLINGHAM, p. 2009).

Em seu já aludido La jaula de la melancolia (1996), Roger Bartra propôs a todos eles, incluindo os referidos autores do pós-1950, Gamio, Ramos e seus contemporâneos/antecessores, uma crítica semelhante. Conforme esse intérprete, o problema das análises acima mencionadas estaria basicamente no fato de substituírem a sistematicidade e a crítica, que haveriam de despertar o povo mexicano ao desconforto frente aos reais problemas enfrentados no país, e ao desacordo, e se teriam dedicado à elaboração de caricaturas, de mitos de coesão social. Por isso, ele afirma: "Los mexicanos debemos deshacernos de esta imaginería que oprime nuestras consciencias y fortalece la dominación despótica del llamado Estado de la Revolución mexicana” (BARTRA, p. 17).

Assim, Bartra aproxima Ramos de intelectuais como - também citado por Gillingham, Manuel Gamio, autor de Forjando pátria (1916). Afirma que esse outro escritor teria declarado que, como pouco se sabia do índio mexicano, era preciso "forjar" "un alma indígena". E que o mesmo seria válido para Ramos, em El perfil: ali também se partiria do intuito de que, se não se conhecia o mexicano, era essencial compô-lo (Idem, p. 110).

O filósofo mexicano Agustín Basave Fernández del Valle, em Samuel Ramos: trayectoria filosófica (1965), já apresentara, antes de Bartra, uma severa crítica a Ramos. À época, partira de quatro suposições básicas, acerca do texto de El perfil: não existir algo que possa ser considerado propriamente essencialmente mexicano; a inadequação da aplicação da teoria psicanalítica a grupos; a inadequação da aplicação da teoria psicanalítica pelo próprio analisado (BASAVE, p. 30-33).

Mais recentemente, o professor da UNAM Mario Magallón Anaya insistiu nas críticas ao método de Ramos, em El perfil, pontuando: "Ramos no tiene claro el método a seguir, a veces se mueve dentro de los margenes del intuicionismo más que de la racionalidad lógica”, de forma que imprime à sua escrita "la dispersión, la vaguiedad, la inconsciencia ontológica y epistemológica. En consequéncia, las ideas claras y distintas se diluyen y hacen difícil hablar con sentido de verdad" (MAGALLÓN, p. 19).

Porém, em texto aqui já aludido, Zagal condena os comuns modos de se interpretar $E l$ perfil, hoje, no México. Ele escreve: 
Existe el acuerdo tácito de que El perfil del hombre y la cultura en México es una pieza de museo. Es un incunable de la cultura mexicana (...). Si en los círculos universitarios más sofisticados sigue enseñándose a Samuel Ramos, es por el mero afán del anticuario. Es el interés de quien se regodea en una pieza demodé de la prehistoria filosófica de México. Las personas cultas saben que Tláloc era el dios del agua, que el mole lleva chocolate, y que Ramos escribió El perfil del hombre y la cultura en México. La fraseología de Ramos, ciertamente, es [considerada] caduca (ZAGAL, 2010, p. 1).

Zagal contesta tais perspectivas e afirma que o dito livro de Ramos tem a vantagem de enquadrar-se na categoria de "lugar comum". Ele lembra, logo, que, para Aristóteles, o "lugar comum" é um eixo de entendimento largamente compartilhado, que pode vir a inspirar profícuos diálogos. Quer dizer: o livro, ainda que tenha sido condenado pela Academia, faz-se indiscutivelmente útil, ao permitir que os mexicanos tomem e retomem, criticamente, a partir dele, as imagens que concebem acerca de si.

Também para o jovem e reputado professor Guillermo Hurtado, autor de El búho y la serpiente (2007), Ramos foi e vem sendo vítima de análises injustas, feitas por intelectuais cientificistas/sistemáticos, incapazes de compreender a importância não apenas histórica, mas também filosófica de suas reflexões. El perfil, ao ver desse autor, não apresentava o "pelado" como "essência" do mexicano, como uma conclusão acabada. Em El perfil o "pelado" surgia como ponto de referência para se pensar o mexicano. Ramos, afinal, segundo Hurtado, não proporia uma discussão ontológica, e sim metafísica (HURTADO, p. 37).

E podemos dizer, efetivamente, que mesmo José Gaos, filósofo espanhol que foi crítico debatedor de Ramos, concordaria com tais perspectivas, propostas por Zagal e Hurtado. Gaos considerava que o tipo "pelado" correspondia a uma "essência" (GAOS, p. 150); entretanto, compreendia que não equivalia a um conceito fixo:,continha em si toda uma dinâmica e complexidade (fora formulado a partir da análise de fatores históricos, culturais, comportamentais, psicológicos, cambiantes); e não estava "acabado" (servia a Ramos como “objeto de manejo y empleo", ao qual se pudesse contrapor novos dados, novas percepções acerca da realidade) (Idem, p. 151).

De forma semelhante, como vimos, pensava Paz. Ele considerava que o autor de $E l$ perfil, na análise dos mexicanos, "pergunta por seus traços, [e] arranca máscaras" (PAZ, p. 142).

O já citado Juan Hernández Luna, contemporâneo de Paz, apresentou uma interpretação semelhante, sobre El perfil: disse que os "tipos" apresentados nessa obra "no son conceptos previamente acuñados para luego aprisionar en ellos la realidad cultural 
mexicana, sino conceptos espontáneamente sugeridos por el análises del fenômeno cultural mexicano" (HERNÁNDEZ LUNA, 1956, p. 106). E mais:

Reconocer que el mexicano actual padece un sentimiento de inferioridad, finalmente, no quiere decir que las diversas modalidades de su carácter pueden explicarse únicamente por ese sentimiento. Este, sin duda, explica las anomalías psíquicas que se han señalado, pero 'quizá existan otras modalidades' del carácter mexicano 'cuyo mecanismo deba ser explicado con otros principios científicos’ (Idem, p. 139).

Partindo de Gaos, Paz, Hernández Luna e do próprio Ramos, enfim, podemos dizer que o "pelado" de El perfil corresponde a um alguém, uma personalidade, que em seu modo singular não incorpora a totalidade; apenas representa o todo, num dado momento. Podemos dizer, assim, que o tipo ideal formulado por Ramos no referido livro não equivale a uma resposta fechada; e sim a uma ferramenta, "objeto de manejo", "mascara", fantasia, contraste, "concepto (...) sugerido por el analisis"; um enigma em aberto, um desafio para reflexão. O que de certa maneira invalida a crítica de Magallón, Basave e Bartra.

A respeito de Bartra, eu diria que por displicência poderíamos tanto associar o nome de Ramos ao de Gamio, quanto ao de qualquer outro intelectual do período; e que, dessa forma procedendo, acaso chegaríamos a conclusões completamente opostas sobre o "pelado", descrito em El perfil. Em outras palavras, eu diria que é preciso tomar com cuidado registros biográficos de autores daquele momento, e também cruzar seus textos, antes de filiarmos uns a projetos de outros. A ambas as questões busco estar atenta, todo o tempo, nesta Tese; e, no caso específico do contraste com Gamio, começo a abordar já no próximo Capítulo.

Quanto a Basave, eu diria não apenas que se equivocava ao propor que Ramos entendia o "pelado" como uma representação de uma dada "essência" do mexicano. Diria, ainda, que Basave revela, em sua análise de El perfil, um entendimento bastante reduzido da teoria psicanalítica, porque ao que tudo indica a Psicanálise considerou sim a dimensão individual, só que sempre em suas articulações com o coletivo, e isso desde seu fundador, Sigmund Freud, autor de textos memoráveis como $O$ mal estar da civilização (1930). Diria, ainda, que, diferentemente do que pontua Basave, a psicanálise partiu sempre do princípio de que é o paciente quem se cura, e não sugestões vindas de fora, embora sejamos a todo o momento bombardeados/acalentados com influências, desafios, questionamentos que nos chegam de outras pessoas, culturas, referências - destarte, Freud declarava, no mencionado texto: "não existe regra de ouro que se aplique a todos; todo homem tem de descobrir por si mesmo de que modo específico ele pode ser salvo" (FREUD, p. 91). 
Se nos concentrarmos no texto de seu referido livro, temos uma irônica resposta de Ramos, aos críticos que desde o lançamento de seus primeiros artigos sobre a cultura mexicana rotularam sua avaliação como reduzida, redutora e demasiadamente severa:

No hay razón para que el lector se ofenda al leer estas páginas, en donde no se afirma que el mexicano sea inferior, sino que se siente inferior, lo cual es cosa muy distinta. (...) Si no obstante estas aclaraciones, el lector se siente lastimado, lo lamentamos sinceramente, pero confirmaremos que en nuestro países de América existe, como dice Keyserling, 'un primado de la suscetibilidad', así su reacción de disgusto sería la más rotunda comprobación de nuestra tesis (RAMOS, p. 118).

Ora, Ramos, a todo o momento, afirmava e reafirmava que sua intenção era ser preciso para que se pudesse ser, no que diz respeito às políticas nacionais, eficaz. Mas também insistia em reiterar que não considerava ser o mexicano inferior; considerava que o mexicano percebia-se como inferior. Em outras palavras, é possível que sua análise não estivesse tão preocupada com uma definição - enquadramento e determinação acabada - e mais com o que é fugaz e sensível - no que se colocava no âmbito dos sentidos.

Além disso, de minha parte considero que não há qualquer registro que indique qualquer vinculação política de Ramos ao dito partido "revolucionário", nem no momento em que escreveu El perfil, nem quando Miguel Alemán encontrava-se na presidência. Perspectivas que, cruzadas às de intelectuais seus contemporâneos, avaliarei na próxima seção deste Capítulo.

A meu ver, afinal, percorre todo o texto de El perfil uma clara tensão entre a esperança e o desconforto em relação à realidade mexicana da época; uma crença na possibilidade de mudança, mas também certa desconfiança acerca de como isso se processaria; uma aposta na educação como ferramenta de transformação, e uma crítica aberta ao sistema de ensino em voga. Dinâmica que não condiz com a ideia da proposital formulação, neste ensaio, de um parâmetro seguro de identificação para os mexicanos.

Nesse ínterim, acredito ser importante lembrar que Hernández Luna destacara, em biografia de Ramos publicada de 1956, que os principais críticos vinham considerando, de $E l$ perfil, as questões que Ramos melhor desenvolveu em livros posteriores; tais como: mexicanidade, Filosofia Mexicana, intuicionismo, pragmatismo, intelectualismo, humanismo. E que, porém, para o biógrafo, Ramos, naquela obra em particular, não havia focado, a bem da verdade, essas problemáticas (HERNÁNDEZ LUNA, 1956, p. 10).

Mais recentemente, nesse sentido, o professor da Universidad Panamericana de México, Luis Patiño Palafox, pontua que, além de El perfil abraçar o campo da Filosofia da Cultura, abordava ainda temas de cunho histórico e político fundamentais. Que, embora a 
bibliografia a respeito de tal livro se tenha centrado em questões culturais e identitárias, a bem da verdade "la estructura misma del texto va centrándose en temas más históricos y políticos" (PATIÑO, p. 6).

Seguindo Hernández Luna, e parafraseando Patiño, então, considero nesta Tese a "necesaria valoración crítica de la obra de Samuel Ramos" (Idem, p. 1). E, no caso, circunscrita aos campos da "História Intelectual" e da "História dos Conceitos", trabalho como em El perfil consta não apenas a tensão entre o local e o estrangeiro, mas ente teorias e práticas, e entre passado e presente, no México. Avaliarei, ainda, as menções que ali Ramos faz: às ideias revolucionárias, à criação de leis naquela época, os comportamentos e relações, no âmbito do poder; à história nacional. 


\subsection{Retomando e comparando}

Até aqui, vimos que tanto Holanda quanto Ramos nasceram longe da capital de seus respectivos países, mas para lá se mudaram, ainda bem jovens. Tanto um como outro cedo ganharam renome, com a publicação de textos críticos - no primeiro caso, mais centrado em questões literárias; no segundo, filosóficas. Dessa maneira informal iniciaram suas trajetórias como reputados intelectuais latinoamericanos, e pronto ganharam tamanho gosto pela reflexão acerca do humano, que não chegaram jamais a atuar nas carreiras "técnicas" para as quais começaram, formalmente/oficialmente, a se preparar - a carreira de Direito, no caso de Holanda; e Medicina, no caso de Ramos. O talento para a crítica apurada e os amigos que fizeram na juventude garantiram a Holanda e Ramos, ainda, empregos públicos: se tornaram professores.

Isso tudo me parece exemplar, na História dos intelectuais da América Latina do início do século XX: a importância das capitais, como centros de difusão e acesso a cultura; a formação intelectual extraoficial, na prática da reflexão e escrita em editoras, revistas e redações de jornal; o diletantismo e a paixão por melhor conhecer o homem, em sua psicologia e relações sociais; a remuneração, o sustento, que vinha do trabalho em cargos públicos.

No curso que a vida tomou, para Holanda, para Ramos, chegaram à Europa na segunda metade dos anos 1920: um, como correspondente de um jornal privado, brasileiro, na Alemanha e na Polônia; e o outro, como representante do governo revolucionário mexicano, na Rússia, de onde partiu para França e Alemanha.

Aí então, tiveram acesso e buscaram sistematicamente conhecer autores que não eram tão conhecidos em seus países, mas cujas proposições há tempos lhes haviam despertado interesse. Por coincidência ou não, tocou igualmente a Holanda e Ramos o interesse, sobretudo, por teóricos da Europa Central, que vinham recorrendo, metodologicamente, à formulação de "tipos". Com uma diferença fundamental: ao referido intelectual brasileiro pareceram mais instigantes as reflexões do sociólogo alemão Max Weber e, é provável, também, - dizem os principais especialistas em sua trajetória profissional - de Georg Simmel; ao referido intelectual mexicano pareceram mais instigantes a reflexões dos discípulos renegados do pai da Psicanálise, Carl Gustav Jung e Alfred Adler.

Inspirados pela possibilidade de analisar a realidade atual de México e Brasil, lançando mão de um viés psicossocial e da composição de tipologias, Holanda e Ramos 
vieram, destarte, a produzir seus ensaios mais célebres: respectivamente Raízes (publicado em 1936) e El perfil (publicado em 1934).

Se contrastados aos estudos mais comuns, à época, sobre o modo de ser de mexicanos e brasileiros, essas duas obras não inovavam apenas por terem se inspirado em metodologia não francesa, espanhola e portuguesa (o que era o mais comum, e portanto, mais seguro). Elas inovavam por considerar o passado sem a pretensão de apresentar tão somente um inventário de fatos nacionais icônicos; e por considerar o "nacional" de maneira crítica - sem elogiar cegamente, pintando um quadro falso de tão colorido; e nem se conformar ante os problemas, e justificá-los com dados supostamente científicos, sobre aspectos raciais.

Pelo interesse generoso no presente, pela observação cuidadosa dos registros do passado, e pelo foco no "cultural" como modo de ser, viver, pensar, agir, se relacionar, Raízes e El perfil apresentaram, assim, diagnósticos que equilibravam angústia em relação ao difícil quadro vivido e insistentemente repetido, e esperança, em relação ao futuro.

Ora, ao longo dos quase 80 anos que nos separam de suas primeiras edições, esses dois livros foram lidos e ressignificados, escritos e reformulados, comentados, criticados e iconizados, de maneira que interpretá-los, hoje, resulta em uma missão consideravelmente complexa.

Ante tais problemas, neste estudo opto por contemplá-los como criações de uma conjuntura específica: um mesmo momento e dois meios diversos, ainda que equivalentes; as primeiras décadas do século XX no Brasil e no México. Tendo isso em mente, sugiro, pois, que muitos dos críticos mais severos de Raízes e El perfil partiram de parâmetros que eram alheios aos parâmetros dos quais dispunham seus autores, quando os conceberam.

Por exemplo: tanto no caso de Holanda quanto no caso de Ramos, observo que tenderam a ser posteriormente filiados a uma tradição política conservadora, pelo simples fato de haverem se interessado por pensar sobre a possibilidade de uma existência autêntica, original, brasileira, mexicana. Tenderam a ser tomados, genericamente, como interessantes aos olhos dos governos pouco democráticos, distintos em suas especificidades, mas que igualmente se estabeleceram e ganharam força no Brasil e no México dos anos 1930.

Outro aspecto problemático que os críticos mexicanos e brasileiros, cada qual em seu país e à sua maneira, costumaram observar em Raízes como em El perfil é a opção, dos jovens Holanda e Ramos, pelo estilo ensaístico, que concedia foco aos ritmos espontâneos das histórias, respectivamente, do México e do Brasil. Contudo, como disse há pouco, se comparados aos estudos da época em que foram produzidos, esses autores lograram ser 
consideravelmente inovadores, e inclusive no sentido de se proporem a ser mais articulados e mais rigorosos, mais precisos.

Por fim, grande parte da crítica condenou em Raízes e El perfil a proposição dos tipos “cordial" e "pelado". Os classificou como falsificações: generalizações forçadas, atribuídas à totalidade dos diversificados povos mexicano e brasileiro; enquadramento restrito das variações que marcam o percurso por nós cumprido da colonização à contemporaneidade.

Entretanto, muitos intérpretes têm demonstrado que esse não era, em verdade, o propósito de tais autores: eles teriam optado pela formulação de tipos não como fim de suas análises, mas como ferramenta de organização e crítica dessa multiplicidade e do confuso devir, que caracterizam a história e o presente, do Brasil e do México. Não teriam, assim, nos ditos livros, a intenção de desvendar ou criar um referencial de identidade nacional, mas partir de alguns entendimentos correntes acerca do nacional (de clichês), para desconstruir versões arraigadas, analisar nuances e continuidades, autenticidade e reprodução.

Para finalizar pontuo, sem inocência, porém, que aqui considero que não se pode chegar a uma leitura "real", ou "mais completa" sobre o que Holanda e Ramos haviam proposto originalmente em Raízes e El perfil. Entretanto, que devemos buscar versões mais justas e bem embasadas, e que tenham em mente a crítica da crítica a tais ensaios, e novas leituras dos clássicos, cruzadas a outros clássicos, produzidos na mesma época.

Cabe considerar nesta Tese, então, algo além dos lugares de Raízes e El perfil concebidos pelas tradições que os interpretaram. Algo além da avaliação do que Holanda e Ramos ali definiram explicitamente pretender fazer, mesmo que não pareçam efetivamente fazer, a nossos olhos, de pesquisadores de hoje.

Dedico-me, pois, no próximo Capítulo, a analisar os posicionamentos desses dois autores como cidadãos, do México e do Brasil, naquela conjuntura específica, de meados da década de 1930, distinta das conjunturas na qual trabalharam muitos de seus seguidores e críticos. E a fazê-los tendo em mente os cargos que ocuparam junto aos governos em voga, naquelas nações, quando escreveram Raízes e El perfil; seus vínculos com os projetos político-culturais oficiais; seus olhares críticos acerca do destino de seu povo.

Ademais, busco estabelecer entendimentos sobre as condições e expectativas investigativas características daquele o período, em que eles estiveram elaborando seus ensaios. E considerar dimensões de "verdade", rigor, racionalidade e importância social em vigor, em seu tempo; assim como de que maneira Ramos e Holanda se teriam posicionado, ante elas. 
Para tanto, foco as relações profissionais estabelecidas; e as cruzo com as trajetórias de diversos outros intelectuais brasileiros e mexicanos, expressivos nas primeiras décadas do século XX, e com quem provavelmente os autores de Raízes e El perfil, então, dialogaram. Os separo entre ensaístas e literatos vanguardistas.

Começo a considerar, então, possíveis relações entre Ramos e Holanda os Estados ditos "revolucionários", naquele momento, no Brasil e no México. E a introduzir algumas percepções correntes sobre o conceito de "revolução", entre brasileiros e mexicanos daquela conjuntura. 


\section{CAPÍtULO 2:}

\section{Raízes e $E l$ perfil frente a outros autores e textos clássicos de princípios dos novecentos}

\subsection{A começar pelos ensaístas brasileiros}

André Botelho, escrevendo sobre o Brasil, sugere que "o ensaísmo não expressa a organização e a atuação de um grupo de indivíduos/autores com interesses coletivos comuns programáticos e deliberados" (BOTELHO, p. 48). Sendo assim, aqui considero alguns autores cujas obras apresentam muitas diferenças, e que por razões diversas se inscrevem no rol das mais importantes de nossa história intelectual.

Antonio Candido, no célebre prefácio a Raízes, publicado em 1967, destacou como os ensaístas que haviam sido mais significativos para sua própria geração, além de Holanda, o pernambucano Gilberto Freyre, e o também paulista Caio Prado Junior. Candido se referiu, no que diz respeito a Freyre, a dois livros: Casa-grande \& senzala (1933) e Sobrados e mucambos (que foi lançado, tal como Raízes, em 1936). No que diz respeito a Caio Prado, Candido sublinhou a importância de Formação do Brasil contemporâneo (CANDIDO, 1999, p. 9).

Nesta Tese, parto das indicações de Candido, mas a Formação do Brasil contemporâneo, de Caio Prado, que foi publicado pela primeira vez em 1942, prefiro Evolução política do Brasil, sua primeira obra, lançada, tal como Casa-grande \& senzala, de Freyre, no ano de 1933.

Antes de considerar concepções políticas e intelectuais desses dois autores, cabe apontar possíveis encontros e/ou pontos de identificação entre Holanda e eles, às vésperas da elaboração de Raízes.

Quanto a Freyre, não se pode deixar de pontuar que foi o único dos ensaístas brasileiros, nesta Tese analisados, citado como referência no texto original de Raízes. E não se pode deixar de pontuar, ainda, que essa referência acabou por ser apagada das edições posteriores do livro.

Conforme Elide Rugai Bastos, as edições posteriores de Raízes, assim como dos livros de Freyre que aqui tomo para análise - Casa-grande \& senzala e Sobrados \& mucambos - se caracterizam por alterações e prefácios que dialogam, através dos anos, tensionados. Daí em diante, confrontados e confrontando-se, Holanda e Freyre responderam as teses um do outro 
sobre a formação cultural de nosso país, em sua diversidade; Holanda e Freyre passaram se apresentar como adversários (BASTOS, 2006).

A opção editorial de Holanda por excluir Freyre das referências bibliográficas de Raízes hoje afinal intriga alguns dos mais sérios intérpretes de Holanda. Segundo Pedro Meira Monteiro, "a razão para isso é que ele quis desesperadamente se diferenciar de Freyre na medida em que percebia no pernambucano uma guinada à direita". Segundo Thiago Lima Nicodemo, a exclusão é representativa das tensões "entre o desenvolvimento de uma cultura acadêmica e universitária [que Holanda, depois de Raízes, passaria a representar] e a interpretação do Brasil [que Freyre e seu insistente ensaísmo representavam]”. Segundo João Cezar de Castro Rocha, por fim, "há componentes políticos, ideológicos e acadêmicos envolvidos na questão" (Apud. LEVINO, p. E5).

Concentrada no tempo em que elaboraram as versões originais de seus livros, eu destacaria que no artigo que antecedeu a publicação de Raízes, Corpo e alma do Brasil, Holanda citou Freyre como autor do "ensaio mais sério e mais completo que já se tentou sobre a formação social do Brasil" (HOLANDA, 2008, p. 586). E que na Apresentação à primeira edição de tal ensaio, quer dizer, de Casa-grande \& senzala, Freyre havia agradecido a Holanda, por ter-lhe traduzido do alemão algumas fontes importantes (FREYRE, 2001, p. 61).

Freyre e Holanda se cruzaram, ainda, nos corredores da Universidade do Distrito Federal, umas das primeiras universidades públicas brasileiras, criada por Anísio Teixeira, funcionário do governo do estado do Rio de Janeiro.

Como nos conta Carlos Guilherme Mota, nenhum desses intelectuais se formou nessa instituição, que foi criada (em comparação com outros países da América Latina) bem tardiamente, em 1935. Tal iniciativa, que enfrentou a oposição do presidente em exercício desde 1930, Getulio Vargas, acabou fechando as portas quatro anos depois (MOTA, 2008, p. $65)$.

Entretanto, naquele curto espaço de tempo, Freyre e Holanda ali puderam trabalhar e aprimorar seus saberes; foi uma experiência importante para ambos. Freyre, que voltava dos Estados Unidos com um diploma de mestre em Ciências Políticas, lá ocupou um cargo mais interessante: foi diretor do Curso de Antropologia Social e Cultural da América Latina (FREYRE, 2004, p. 897). Já Holanda, formado em Direito mas simples jornalista e figura conhecida dos rodapés de crítica de periódicos da capital e de São Paulo, foi a princípio professor assistente de pesquisadores franceses convidados por Teixeira, e, só depois, acabou 
por assumir as cadeiras de História da América e História da Cultura Luso-Brasileira (HOLANDA, 1979, p. 14).

Rocha lembra, ainda, que Raízes foi a primeira obra publicada da coleção organizada por Freyre para a Editora José Olympio, Documentos Brasileiros. E que o próprio Freyre escreveu seu primeiro Prefácio, posteriormente apagado.

Nesse texto, é verdade, o autor nordestino mais comentava a iniciativa editorial do que o trabalho de Holanda. Em breve passagem, pontuava tão somente que considerava

o escritor paulista (...) uma daquelas inteligências brasileiras em que melhor se exprimem não só (...) a capacidade de analisar [como] a alegria intelectual de esclarecer"; e que "quando [Holanda] apareceu, há dez ou doze anos, (...) foi logo revelando as qualidades e o gosto, que agora se afirma[vam] vitoriosamente (FREYRE, 1936, p. 3).

Conforme Rocha, Freyre assim marcava uma simpatia pessoal por Holanda - para usar palavras desse crítico, "numa irônica (porque involuntária) referência ao conceito de cordialidade enquanto predomínio dos afetos e das relações pessoais" (ROCHA, p. 248). Mas, de qualquer maneira, deixava registrada, também, certa identificação teórica; que aqui será em breve analisada.

As relações entre Holanda e Caio Prado Junior, na juventude, se ocorreram, não chegaram a ser significativas. Ou, ao menos, os dois autores não guardaram registro de qualquer lembrança de encontro ou contato na São Paulo da década de 1920.

Com a mudança de Holanda para o Rio de Janeiro, reduziu-se a possibilidade de se cruzarem, se conhecerem, se influenciarem diretamente.

Nesse sentido, cabe lembrar que as reuniões que levaram à organização, em São Paulo, de nossa célebre Semana da Arte Moderna, de 1922, se deram em grande parte na residência de um primo de segundo grau de Caio, o Paulo Prado; conforme Paulo Teixeira Iumatti, interessado com as novidades e a convite do parente, o adolescente Caio Prado Junior acabou por se fazer presente no evento (IUMATTI, p. 65).

Quanto a Holanda, como veremos, foi amigo íntimo dos nomes mais expressivos daquela iniciativa; e, mesmo vivendo na capital do país, seguiu sendo considerado uma peça importante do grupo que se reunia em terras paulistanas.

Porém, como ele próprio contou, em entrevista de 1981, não pôde estar com os companheiros, na dita Semana: "Não pude porque tinha exame na faculdade. Eu tinha faltado às provas no ano anterior, o primeiro ano de Direito. A única solução era fazer a segunda época, e os testes caíram exatamente em fevereiro de 1922” (Apud. MARTINS, p. 177). 
Ainda assim, a despeito dos desencontros, pode-se dizer que há muito em comum entre os percursos intelectuais de Caio Prado e Holanda.

Como filho da elite paulistana, o primeiro cumpriu seus estudos secundários na Inglaterra, mas formou-se, como Holanda, em Direito. Anos depois, cursou aulas na Faculdade de Filosofia, Ciência e Letras da Universidade de São Paulo, que, como empreendimento paralelo à UDF, foi criada em 1934, por Armando Sales, interventor de Vargas neste estado. Na época em que Caio Prado por ali circulou, em experiência também semelhante à de Holanda, esteve em contato com diversos professores franceses, convidados por Sales (CARDOSO, p. 31).

Com o retorno de Holanda para São Paulo, e sua inserção acadêmica justamente nessa instituição universitária frequentada por Caio Prado na juventude, esses dois ensaístas e, logo, reputados investigadores, puderam afinal se alcançar. Mas aí então Caio Prado Junior já se deslocara um tanto para o campo da Geografia, e depois, do universo acadêmico, para a militância política.

Ainda assim, deve-se registrar, partindo dos estudos de Iumatti, que desde Caminhos de fronteiras (1956) Holanda "dialogava [intensamente] com a obra de Caio Prado Junior (...) e o considerou, como lembra Maria Odila da Silva Dias, o grande historiador que o Brasil havia produzido no século XX" (IUMATTI, p. 177).

Além de Freyre e Caio Prado, há, ainda, outros dois intelectuais brasileiros, que contavam maior idade, mas que tendem a ser sempre considerados grandes expoentes de nosso ensaísmo da primeira metade do século XX. São eles: o mencionado primo mais velho de Caio, Paulo Prado, autor de Paulística (1925) e Retrato do Brasil (1928); e o sergipano Manoel Bomfim, autor de América Latina: males de origem (1905), O Brasil na América (1929), O Brasil na História (1930), e Brasil nação (1931).

Deve-se pôr em nota, desde já, que a geração de Paulo Prado e Bomfim foi uma geração em que os estudos históricos se deram sob um aparato profissional um tanto mais complexo. Entre Freyre, Holanda e Caio Prado, como vimos, apenas o primeiro dedicou-se ao estudo do passado nacional, desde o princípio dentro de uma instituição universitária; mas os outros dois foram ainda bem jovens marcados pelas experiências da UDF e da USP. Quanto a Paulo Prado e Bomfim, compuseram seus estudos, variavelmente, como autodidatas e não especialistas.

Segundo Rebeca Gontijo, “durante o século XIX, na Europa (...) A história ganhou espaço nas universidades, aumentando a expectativa de profissionalização do trabalho do historiador, ao mesmo tempo em que se afirmava uma concepção moderna de história. 
Enquanto isso, no Brasil, os lugares da produção científica eram os institutos históricos e geográficos, os museus etnográficos e as faculdades de direito e medicina, onde a ciência com suas diferentes teorias, interpretações e experimentos - dava lugar à discussão e divulgação de uma ética ou atitude científica possível de ser experimentada de modo genérico" (GONTIJO, p. 133).

O paulista Paulo Prado, que atuava em empresas de imigração, exportação de café, e construção de estradas de ferro, de sua família, tardou a descobrir o interesse pelos estudos de história; quando decidiu dedicar-se a tais problemas, lhe pareceu tarde para investir em estudos no exterior - já contava quase cinquenta anos. Antes disso, segundo Carlos Augusto Calil, havia vivenciado experiências que nos remetem diretamente às bases de formação intelectual no Brasil de princípios dos novecentos, apontadas por Gontijo: embora não tenha estabelecido relações formais com IHGBs, conviveu com alguns de seus mais renomados integrantes, como Capistrano de Abreu; e se formou em Direito, em São Paulo mesmo (CALIL, p. 34 e 35).

Além disso, destaca-se da formação intelectual de Paulo Prado o fato de ter trabalhado em diversos projetos de difusão cultural, dentre os quais a dita Semana da Arte Moderna, e importantes periódicos. Entre 1923 e 1925, por exemplo, substituiu Monteiro Lobato na direção da Revista do Brasil. A propósito, conforme Thaís Chang Waldman, "sob sua direção, a Revista do Brasil, antes um órgão de cunho mais acadêmico, a princípio indiferente e depois até mesmo ligeiramente hostil [às novas gerações de literatos brasileiros], passou a simpatizar com o movimento modernista" (WALDMAN, p. 11).

Holanda, como disse e avaliaremos melhor adiante, também esteve em contato com os agitadores da Semana. Ademais, deve ter cruzado ou mesmo trocado impressões com o empresário paulista em razão da Revista do Brasil, para a qual, ainda que fosse editada em São Paulo, ele enviou do Rio de Janeiro inúmeras contribuições (EULÁLIO, p. 260).

Apesar disso, há poucas indicações de que Holanda tenha admirado o trabalho de Paulo Prado como intérprete do Brasil moderno. O único registro que acessei, a respeito, foi uma entrevista tão somente da década de 1980, na qual Holanda a ele aludiria em comentários vagos, e tom de descaso e crítica. "Ele fez um livro que eu acho ruim, que é Retrato do Brasil. Era um ensaísta, um homem muito viajado e rico" - "Nada mais do que isso", parecia dizer (Apud. MARTINS, 2009, p. 191).

Como nos contou Darcy Ribeiro, Bomfim começou o curso de Medicina na Bahia, e o conclui no Rio de Janeiro, onde passou a viveu a partir de 1890. Na capital do país, seguiu interessado por questões médicas, sanitárias e biológicas; mas leu também bastante sobre 
História, Psicologia e Pedagogia - lembrando a trajetória de Ramos, aludida no primeiro Capítulo desta Tese (RIBEIRO, 2005, p. 15).

Em face de tais dispersos interesses, Bomfim partiu para a Europa, para estudar Psicologia e Pedagogia, entre os anos de 1902 e 1903. Tal experiência foi fundamental na trajetória desse ensaísta, que começou a escrever América Latina: males de origem ainda em território estrangeiro (Idem, p. 13).

De volta ao Brasil, Bomfim seguiu escrevendo sobre história; e, ao longo da década de 1930, mais especificamente sobre a história de nosso país, de que resultou a já aludida trilogia. Destacou-se, ainda, em instituições de ensino e de pesquisa sobre o ensino; e na elaboração de livros didáticos.

Curioso, portanto, um detalhe: dentre os cinco ensaístas brasileiros aqui aludidos, Bomfim foi aquele que mais publicou livros, entre as décadas de 1920 e 1930; mas, nos anos que se passaram, foi o autor que menos interesse despertou, entre os estudiosos do ensaísmo, no Brasil. Difícil dizer, então, se Holanda e ele chegaram a se conhecer, no Rio de Janeiro daqueles tempos - a probabilidade é imensa, contudo, desconhecido o registro.

Ora, é possível que Holanda, às vésperas de escrever Raízes, observasse o trabalho de pesquisa história de Bomfim com a mesma desconfiança com que provavelmente observou o trabalho de Paulo Prado. Entretanto, como veremos adiante, fato é que seu texto tem bastante em comum com os textos do primeiro desses autores, na mesma medida em que se afasta das publicações desse segundo, com o qual compartilhou não apenas a origem paulista e o amor por São Paulo, como diversos amigos e colaboradores intelectuais.

Antes de avaliar as concepções teóricas e metodológicas de cada um desses escritores, contudo, volto-me a repensar os posicionamentos políticos de cada um deles; visando avaliar ampliar os entendimentos a respeito das bases sobre as quais se estruturaram os interesses de uns e outros pelo estudo do Brasil, seu passado e seu presente.

No dito Prefácio a Raízes do Brasil de 1967, Candido defendeu que os trabalhos produzidos pelo grupo de pensadores mais expressivos da década de 1930 haviam sido percorridos por um dado "sopro de radicalismo intelectual" (CANDIDO, 1999, p. 9). A seu ver, tal tendência teria "eclodido depois da Revolução de 1930 e não foi, apesar de tudo, abafada pelo Estado Novo" (Ibidem).

Em curto mas já clássico artigo, Antonio Candido estabeleceu alguns parâmetros para se pensar especificamente o posicionamento político de Holanda, desde a juventude, até a maioridade. Ali o renomado crítico defendeu a tese de que, embora "nunca tenha sido um 
militante político", as posições ideológicas do autor de Raízes sempre teriam se definido "para o lado da esquerda" (CANDIDO, 1998, p. 81).

Segundo Candido, era preciso ler-se com muita atenção os capítulos finais de Raízes, porque, conforme seu entendimento, embora nublados, eles estariam repletos de referências críticas ao regime político então em vigor, no Brasil (CANDIDO, 1999: 18). Sem mencionar o regime ditatorial e personalista de Vargas, haveria ali, por exemplo, uma notável insistência em criticar "tendências reacionárias", "caudilhismo", "personalismo e arbítrio" (IDEM: 20).

Alguns fatos da biografia de Holanda foram apresentados por Candido, para sustentar tal ideia; a começar pela a estadia de Holanda na Alemanha dos anos 1930, onde teria presenciado a ascensão do nazismo, onde teria intensificado a aversão a toda forma de opressão política. Candido também afirma que Holanda teria sido um claro opositor do regime Vargas. Maria Amélia, viúva de Holanda, ademais, conta que ele foi preso quando a Revolução Constitucionalista estourou em terras paulistas: "em 1932, Sérgio estava no Rio, na turma dos boatos e da torcida revolucionária; acabou preso, soltando vivas a São Paulo" (HOLANDA, 2006, p. 433).

Especificamente sobre a dita "Revolução de 1930", não há qualquer menção em Raízes. Mas, para levantar algumas hipóteses sobre o posicionamento político de seu autor, podemos recorrer a há uma série de artigos, produzidos por ele, enquanto ainda andava pela Europa. Embora na ocasião da chegada de Getulio Vargas ao poder, Holanda estivesse fora do país, fato é que não deixou de esboçar apreciações sobre aqueles acontecimentos; e, então, demonstrou pouco entusiasmo ante o que chamou simplesmente "questão da sucessão presidencial”, e "problema das candidaturas" (Apud. BARBOSA, 1988, p. 162).

Naqueles textos, ainda sob aparente tentativa de minimizar a importância política do ditador empoçado, Holanda aludia ao interesse dos europeus pelo que sucedia no Brasil, e transcrevia a seguinte versão, lida por ele em um dos jornais berlinenses: "Washington Luis, que foi presidente de São Paulo, antes de ocupar a suprema magistratura da nação, arvorou como seu candidato o atual presidente de São Paulo, Julio Prestes. Dezessete, dentre os vinte estados, manifestaram-se pela nomeação de Prestes, três, apenas, entre os quais o Rio Grande do Sul, que goza de larga influência, emprenham-se pelo presidente desta última unidade da Federação, o Sr. Getulio Vargas" (Idem, p. 217).

Holanda destacava, ademais, em seus registros, que os informantes alemães demonstravam considerar Prestes como mais capacitado a promover estabilidade e melhorias econômicas; e pareciam "geralmente bastante pessimistas" em relação a Vargas (Idem, p. 216). 
Para Leopoldo Waizbort, entretanto, na terceira edição de Raízes, prefaciada por Candido em 1967, o texto de Raízes teria sido vastamente modificado no sentido de conformar-se a um novo tom de defesa de políticas democráticas, de esquerda (WAIZBORT, 2011, p. 39).

Waizbort compara, por exemplo, o seguinte trecho de Corpo e alma do Brasil, e o seguinte trecho equivalente, que consta na dita terceira edição de Raízes:

Em Corpo e alma do Brasil, lê-se:

A tese de que os expedientes tirânicos nada realizam de durável é apenas uma das muitas invenções fraudulentas da mitologia liberal que a história jamais confirmou. (...) É certo que isso não constitui argumento sério contra o liberalismo e que existem, sem dúvida, outros recursos além das tiranias, para a consolidação e a estabilização de um organismo social e nacional. Importa, no entanto, relegar aos seus justos limites o domínio dos princípios e das fórmulas políticas (HOLANDA, 2008, p. 596).

Já na atual edição de Raízes, aparece a seguinte passagem (com itálicos meus):

A tese de que os expedientes tirânicos nada realizam de duradouro é apenas uma das muitas ilusões da mitologia liberal, que a história está longe de confirmar. É certo que a presença de tais ilusões não constitui em si argumento contra o liberalismo e que existem [exclusão de palavras] outros recursos além da tirania [opção pelo plural], para a consolidação e a estabilização de um conjunto social e nacional. Importa, de qualquer modo, relegar aos seus justos limites o domínio dos princípios e das fórmulas políticas (HOLANDA, 1999: 120).

Ora, vastas são as possibilidades interpretativas aventáveis a partir do contraste entre esses dois trechos. Aqui, explorarei apenas uma, mais específica, e interessante para a reflexão por hora proposta, sobre os posicionamentos políticos de Holanda.

Note-se que num primeiro momento Holanda falava em "invenções", e depois em "ilusões" da "mitologia liberal". A palavra "invenções", a meu ver, possui uma carga mais forte e ativa, enquanto "ilusão" denota passividade; do que poderíamos - com Waizbort depreender uma maior desconfiança, receio, aversão, por parte do jovem Holanda, no que diz respeito aos projetos ditos liberais.

Daí poderíamos considerar possíveis identificações entre concepções políticas do ditador Getulio Vargas e Holanda? De fato, Holanda contribuiu para projetos do Ministro da Educação e Saúde Pública varguista, Gustavo Capanema. Por aqueles anos Holanda integrou a Comissão de Teatro, e foi funcionário do Instituto Nacional do Livro, e da Biblioteca Nacional (HOLANDA, 1979, p. 434-436). Mas isso seria suficiente para propor uma filiação, uma admiração, um comprometimento intelectual, com os projetos governamentais de Vargas? 
Para Waizbort, a desconfiança no que diz respeito ao liberalismo não implicaria, contudo, por si só, no "alinhamento" do jovem Holanda "seja à ditadura, seja à anarquia". Decerto, tanto nas versões iniciais como nas versões finais de Raízes, ele foi bem claro nas críticas às concepções totalitaristas, e também ao descompromisso dos brasileiros com o cumprimento de leis. Mas esse receio no que diz respeito ao liberalismo, ao ver de Waizbort, talvez denote que Holanda "se identificava com [a possibilidade de] um regime oligárquico, tingido por lideranças pessoais (talvez populistas)"(WAIZBORT, 2011, p. 42).

Waizbort, a propósito, cita uma passagem da primeira edição de Raízes que considera fundamental para entender o posicionamento político, anti-liberal e de nuance conservador, do jovem Holanda; qual seja: “A formação das elites de governantes em torno de personalidades prestigiosas, tem sido, ao menos por enquanto, o princípio político mais fecundo em nossa América” (Apud. WAIZBORT, 2011, p. 42).

Acontece que me parece indiscutível, nas diversas versões do dito ensaio, a continuada crença de Holanda em múltiplas alternativas para além do liberalismo, característico da chamada República Velha, formal e pouco efetivo, localista e pautado em interesses rurais arcaicos; e também em múltiplas alternativas para além de um personalismo, sempre tendente à virulência, e que caracterizava já o governo de Vargas. E a verdade é que, se retomarmos as transcrições acima, temos que, no texto de 1935, de Holanda, há a forte presença da expressão "sem dúvida", acompanhando a ideia da possibilidade de se promover coesão social sem a presença de um líder forte.

Segundo Maria Amélia, quando Holanda conheceu Freyre, no final dos anos 1920, Freyre era chefe de gabinete do governador de Pernambuco, Estácio Coimbra (HOLANDA, 1979, p. 431); Coimbra, opositor de Vargas, foi exilado em 1930, e foi então acompanhado, voluntariamente, pelo futuro autor de Casa-grande \& senzala \& Sobrados e mucambos.

De volta ao Brasil em 1935, Freyre, como vimos, aceitaria o convive do baiano Anísio Teixeira, para trabalhar na UDF. Eles se haviam conhecido nos Estados Unidos, onde Freyre cursara Ciência Política, sob orientação de Franz Boas, e Teixeira Pedagogia, sob orientação de John Dewey. Teixeira, a despeito das inúmeras diferenças em reação a Coimbra, foi também considerado inimigo político, por Vargas; e acabou abandonando importantes iniciativas educacionais no Distrito Federal, e se refugiando no sertão da Bahia.

Bom lembrar, então, que em 1937, Freyre passou a trabalhar para o Serviço de Patrimônio Histórico e Artístico Nacional, outra iniciativa do ministro varguista Gustavo Capanema. Primeiro passo no sentido de um diálogo maior com o regime instituído? Não. Conforme Lucia Lippi de Oliveira, Freyre não tardou a ser considerado opositor do 
interventor de Vargas em Pernambuco, Agamenon Magalhães; é foi, por fim, preso por "delito de opinião" e por supostamente flertar com o comunismo (OLIVEIRA, 2011, p. 118).

Conforme Darcy Ribeiro, essas adesões de Freyre a projetos de opositores de Vargas não implicavam, por princípio, qualquer comprometimento ideológico com projetos antiditatoriais, para o Brasil. Ao menos era o que sua atividade intelectual indicava. Para Ribeiro,

o que não fez [em Casa-grande \& senzala \& sobrados e mucambos] foi dar qualquer contribuição útil para vitalizar um valor real, afirmativo das culturas oprimidas; e muito menos despertar na gente que as detém uma consciência crítica ou uma postura rebelde contra a ordem social que as explora e oprime. Em lugar disso o que fez foi justificar o despotismo (RIBEIRO, 2001, p. 18).

Segundo de Dante Moreira Leite: entre Coimbra, Teixeira, Capanema e Magalhães, Freyre deve ser percebido como autor cuja trajetória individual e ímpar, sempre de alguma maneira politicamente, ideologicamente, "identificada com as forças conservadoras da política brasileira" (LEITE, 2007, p. 357).

Para Gustavo Mesquita, nesse sentido,

Gilberto Freyre buscava as brechas no regime autoritário para conceber suas ideias sociológicas que, devido à destituição da aristocracia rural pernambucana do poder por consequência política da Revolução de 1930, privilegiavam o ponto de vista da memória social da região nordestina referente à longa duração da hegemonia do comércio exportador açucareiro (MESQUITA, 2012, p. 12).

Num lado oposto, estariam os Prado - obviamente, Caio Junior se revelaria mais radical do que o primo mais velho; mas esse também se caracterizaria por um posicionamento político progressista.

Como nos conta Calil, "moço fidalgo", Paulo Prado havia indicado, anos antes da publicação de Retrato do Brasil, em uma resenha a importante livro de poemas vanguardistas, o desejo de "fazer tabula rasa dos últimos cem anos da história nacional e ver restabelecidos 'o bom senso terra-a-terra e a visão clara e burguesa das coisas e dos homens" (Apud. CALIL, p. 33 e 15). Em outras palavras, bem ao gosto de consideráveis estratos da vanguarda brasileira, e bem ao gosto do empresariado paulista, declarara pretender desmistificar o passado nacional a partir de uma observação pragmática de nosso passado e de nosso presente nacionais; abordagem para a qual acreditava estarem capacitadas tão somente as "novas" elites burguesas.

Paulo Prado entendia, pois, o pensamento como uma importante forma de agir no mundo; e a produção intelectual como uma atividade necessariamente política. De maneira que, em uma carta de 1929, endereçada ao filho, escreveu: "creio que estou à frente dos que 
preconizam a Ação, e da única maneira possível neste momento: agitando e discutindo. Agir é fácil, o difícil é pensar, dizia Goethe” (PRADO, 2001, p. 218).

Porém, não deixava de perceber a importância da ação política. No Post-scriptum de Retrado do Brasil, sintetizara sua ode às políticas institucionais, da seguinte maneira: "Sobre este corpo anêmico, atrofiado, balofo, tripudiam os políticos. É a única questão vital para o país - a questão política. Feliz ou infelizmente não há outro problema premente a resolver: nem social, nem religioso, nem internacional, nem de raças, nem graves casos econômicos e financeiros. Somente a questão política, que é a questão dos homens públicos” (Idem, p. 205).

Seguindo as investigações de Calil, poderíamos propor que Paulo Prado se dedicou a tal universo não apenas como pensador e autor. Ele emprestou seus talentos intelectuais como negociador: participou das tomadas de decisão ante a crise do café, decorrente do Crack da Bolsa de Nova Iorque; e foi signatário das reuniões que levaram ao alinhamento do Brasil com França, Inglaterra e Estados Unidos, na Primeira Guerra (CALIL, p. 37).

Lembremos, ainda, que Paulo Prado conheceu o universo político intimamente, já que o pai foi funcionário do Império e, na transição do século XIX ao XX, duas vezes prefeito da cidade de São Paulo (Idem, p. 35). Em 1926, seu pai participou da fundação do Partido Democrático (Idem, p. 41).

Em estudo sobre esse organismo, Maria Lígia Prado sugeriu não se tratar de uma representação tão somente de setores agrários paulistas, críticos à atuação do PRP no enfrentamento da crise do preço café. Ao ver da historiadora, seria um partido composto por elementos dos mais variados setores sociais - de grandes proprietários de terra, a investidores de capital, banqueiros e comerciantes; e que desejavam alterações na dinâmica política conservadora, que só seria interrompida com a chamada "Revolução", em 1930 (PRADO, 1986).

Por aqueles anos, então, o autor de Retrato do Brasil, deferia severas críticas ao que considerava a "farsa da democracia representativa", em nosso país. E lamentava que "entre os inteligentes, os sagazes, os estúpidos, os bem-intencionados (dantesca multidão)”, estivessem "desaparecendo rapidamente os [políticos] que possuíam, na expressão dos historiadores românticos 'o magnetismo da personalidade"' (PRADO, 2001, p. 205). Nos anos que antecediam o golpe que retirou o PRP do controle da presidência e empossou o gaúcho Getulio Vargas, Paulo Prado argumentava, ainda, que da instabilidade política havia sempre a chance de emergir um "herói providencial”, ou um “ditador" (Idem, p. 209).

Contudo, com o tempo Paulo Prado se revelaria bastante insatisfeito com os rumos tomados pela política nacional, pós-Vargas. Assumiu, assim, pouco a pouco, o estereótipo do 
intelectual brasileiro decepcionado (estereótipo compartilhado, creio eu, por Holanda, e, tal qual será demonstrado adiante, também pelo poeta Mario de Andrade). Conforme Calil, "nada mais escreve depois de 1934; e nem mesmo autoriza a reedição ou a tradução Retrato do Brasil" (CALIL, p. 19).

Em artigo estampado nas páginas da Revista nova, em 1931, diz Calil, Paulo Prado "acusou Getulio de ditador, e ironizou a retórica salvacionista deflagrada pela fixação da data das eleições constituintes"; "não os assinou, provavelmente para se resguardar de retaliações oficiais, mas seu estilo era inconfundível” (Idem, p. 44).

Para Iumatti, Caio Prado foi um radical, entre os Prado; porém, não se pode negar que seu radicalismo fincou bases em uma concepção política familiar, compartilhada, caracterizada pelo "inconformismo moral", pela "rebeldia", pelo anti-reacionarismo; por "uma estrutura familiar dinâmica e flexível, que permitia o abandono de velhos laços e a criação de novos em resposta às mudanças culturais, econômicas e políticas" (IUMATTI, p. 139).

Paulo e Caio Prado Junior se caracterizaram, portanto, em igual medida pelo entendimento de que os intelectuais tinham e deveriam estar atentos ao fato de que tinham um importante papel social, político, crítico, no Brasil de sua época.

Conforme Iumatti, "muito embora" Caio Prado Junior "declarasse, anos depois, que sua participação em 1930 havia sido mínima", ele decerto trabalhou "na articulação entre os conspiradores, bem como na sabotagem dos meios de comunicação que seriam usados para destruir as forças destinadas a facilitar o avanço das tropas que viriam do Sul” (Idem, p. 142).

Quando instituído o governo varguista, prestou serviço como advogado, recémformado, em oficinas encarregadas de avaliar possíveis casos de corrupção do regime deposto. Porém, tal como o primo mais velho, acabou por desencantar-se.

Segundo Iumatti, Caio Prado Junior sentiu que os "ideais de subversão da ordem e de construção de alicerces efetivamente democráticos - expressos textualmente poucos anos antes por Paulo Prado, em Retrato do Brasil - não seriam cumpridos” (Idem, p. 143). Ou sentiu que não o seriam por Vargas e pelos apóstolos da Revolução de 1930. Daí, iniciou sua busca por outras alternativas; daí o interesse cada vez mais claro pelo socialismo e pela interpretação materialista de Karl Max, como veremos a seguir; daí a filiação ao Partido Comunista, em 1931.

Conforme Rebeca Gontijo a escrita de Bomfim se caracterizou, tal como a escrita dos Prado, por duas dimensões, associadas: "cientificismo" e "civismo"; quer dizer, crítica e função social (GONTIJO, p. 131). Segundo Simone Petraglia Kropf, em América Latina: 
males de origem "afirmava uma postura e um discurso questionadores em relação à chamada modernização republicana" "no auge do otimismo quanto ao programa de regeneração nacional" (KROPF, p. 84).

Marcus Venicio Ribeiro alude à "rarefeita influência do marxismo" na escrita de Bomfim (RIBEIRO, 1998, p. 8). E Darcy Ribeiro nos lembra que "Caio Prado ainda estava nascendo quando Manoel Bomfim nos falava com exatidão do caráter classista, intrinsecamente tirânico e espoliativo do Estado brasileiro" (Idem, p. 18).

Ronaldo Conde Aguiar, que cuidou de aspectos biográficos, admite que Caio Prado foi um marxista oficial e extremado, enquanto Bomfim nem mesmo chegou a integrar o Partido Comunista Brasileiro; porém, diz Aguiar, o ensaísta sergipano teria sido sim claro simpatizante do socialismo, e em diversos textos publicados na imprensa a capital teria louvado a fundação do PCB. Em seus livros, o compromisso político se expressaria, ao ver de Aguiar, afinal, em duas direções: a princípio, ou em América Latina: males de origem, na defesa da educação popular; nos livros posteriores, como Brasil nação, na defesa de uma Revolução político-institucional (AGUIAR, 2000).

Conforme Venicio Ribeiro, porém, o mais fundamental na escrita de Bomfim foi a percepção da importância da dimensão política de práticas não-institucionais. Para esse pesquisador, "numa época em que o Estado ainda era o foco principal dos ideólogos brasileiros, ele propunha a organização da sociedade a partir dela mesma, a construção da cidadania e da democracia" (RIBEIRO, 1998, p. 10).

Talvez possamos dizer, então, que, nesse ponto, Bomfim foi, dentre os ensaístas brasileiros aqui analisados, aquele que apresentou maior proximidade com Holanda. Nem tão conservador quanto Freyre, nem tão liberal quanto Paulo Prado, nem marxista como Caio Prado Junior, o autor de Raízes do Brasil teria cuidado de pensar os comportamentos políticos mais cotidianos, de centrar ali sua crítica, observar ali o cerne dos principais problemas nacionais, e ansiar que lá se promovesse alterações definitivas.

Leonídio, porém, argumenta que Bomfim, por fim, não "acreditava na ação autônoma popular", porque "defendia que somente um longo processo educativo seria capaz de inculcar nos operários a "verdadeira ideia de liberdade"” (LEONÍDIO, p. 196). Ora, esse é justamente o ponto que o afastaria de Holanda. Conforme veremos, no texto de seu mais célebre ensaio, publicado pouco depois dos mais notáveis livros de Bomfim, Holanda foi profundamente crítico dos discursos - para ele, "inútil retórica" - que apresentavam projetos educativos, em geral estrangeiros e artificiais, como única, principal ou simples salvação do povo brasileiro (HOLANDA, 1999, p. 165). 
Ainda que esses autores tenham apresentado propostas bastante diversas, há, porém, muitos pontos em comum entre elas. Em primeiro lugar, todos eles foram críticos a interpretações ufanistas, com abordagens essencialistas em tendências românticas, alheias ao "país real". Em segundo lugar, apresentaram versões sobre a história nacional que não estavam centradas em fatos oficiais. Em terceiro lugar, se dedicaram, cada qual à sua maneira, a compor alternativas às interpretações cientificistas, baseadas em dados raciais, e que denegriam e concluíam como irreversível a condição de dependência e atraso de nossos países e cidadãos.

Sugiro, então, que nos anos 1920 e 1930 houve algo como uma nova onda de desconfiança no que diz respeito aos padrões de verdade instituídos.

$\mathrm{Na}$ apresentação de América Latina: males de origem, Bomfim confessava: "nem mesmo tenho [em mãos] nenhum dos livros que me inspiraram. [Da Europa], onde, forasteiro, escrevo dispondo apenas de notas, reunidas durante nove anos"; e declarava trabalhar conforme sua subjetividade, sua emotividade, sua inconformidade (BOMFIM, 2005, p. 37). A seu ver, prosseguia, se dispusesse de um material mais completo ou mais homogêneo, e se aplicasse a linguagem pretensamente imparcial, "usual" nos tratados de então, era provável que viesse a produzir um trabalho cuja forma, o modo de exposição, fosse diferente. Não podia concordar, contudo, que variaria a nova luz que desejava lançava na observação dos homens e dos países latinoamericanos.

Assim, Bomfim, que, como vimos, estudou ciências naturais e, portanto, bem conhecia padrões científicos de investigação, optava por ir além. Optava por aplicar os vastos conhecimentos adquiridos em laboratórios não num sentido utilitário, como era comum, e sim como erudição que inspiraria a revisão dos modos de se pensar a América Latina, o Brasil.

Em sua trilogia sobre a história do Brasil, Bomfim viria a detalhar sua crítica especificamente à ciência histórica; mais precisamente, o fez em O Brasil na História (1930). Conforme Gontijo, aí se destaca a condenação do ensaísta não apenas às pesquisas ditas científicas, sobre as raças, mas também ao vazio dos trabalhos factuais, e a defesa de uma história mais interpretativa. Para essa pesquisadora, Bomfim destarte "se esquivava da pesquisa documental (arquivística), optando por se dedicar à crítica da historiografia" (GONTIJO, p. 141).

Quanto a Paulo Prado, diz Calil, desde a primeira edição de Retrato do Brasil, foi criticado por "manipular as fontes a serviço de uma tese arbitrária" (CALIL, p. 14).

Robert Wegner sugere que, se no título Paulo Prado apelou para a metáfora do "retrato", nas linhas de seu ensaio mais famoso pretendeu trabalhar tal como um Edgar Degas 
ou um Claude Monet - menos como um jornalista, interessado em registrar os momentos, do que como um artista, interessado em se expressar a respeito do que se passava. Paulo Prado não teria, portando, concebido um texto caracterizado por precisão fotográfica, e sim por uma composição bem própria, na qual se "diluíam os contornos" dos fatos (WEGNER, 2006, p. 338). Conforme Monteiro, "No lugar das tradicionais datações e descrições factuais, restariam [pois, ali] os elementos essenciais que dominam os indivíduos e a coletividade, transpostos para aquele 'retrato' através de 'manchas, mais luminosas, ou extensas'”' (MONTEIRO, 1999, p. 67).

Se compararmos os padrões de verdade de que dispuseram Bomfim e Paulo Prado, poderíamos dizer, então, que ambos não estavam interessados no rigor de observação de documentos, e de catalogação de dados; se deslumbravam e investiam na oportunidade de propor um viés novo, pessoal, para a história nacional brasileira.

O mesmo é válido no que diz respeito a Evolução política do Brasil, de Caio Prado Junior. Sim, porque esse autor, que publicou alguns anos depois, também recebeu severas acusações, justamente voltadas ao fato de não ter se baseado em vasta consulta a arquivos. Segundo Fernando Henrique Cardoso, em célebre conferência, esse ensaio compunha uma interpretação "viva", "ampla" e inteligente de nosso país, mas pautada basicamente em "fontes secundárias" (CARDOSO, p. 32).

Contudo, fato é que já no prefácio à primeira edição desse livro de 1933, o ensaísta marxista paulista demonstrara consciência, no que diz respeito às limitações de sua análise ou, para usar um termo seu: no que diz respeito aos "defeitos" dela. Explicitava isso, e explicava ao leitor que o texto que tinha em mãos não era "uma História do Brasil", e não se pretendia detalhado ou "completo"; era um "simples ensaio", uma "síntese", uma “compreensão geral" (PRADO, p. 7).

A respeito das proposições contidas em Casa-grande \& senzala e Sobrados \& тисатbos, Leite afirmou que seriam quase sempre imprecisas, senão inteiramente descartáveis (LEITE, 2007: 371). Por exemplo:

Ao comparar o sobrado, habitação de gente rica, e o mucambo, habitação de gente pobre, (...) Freyre admite que, quando o mucambo é construído em terreno enxuto, e está bem abrigado da chuva, o pobre está mais higienicamente 'instalado no trópico' do que o rico. Essa afirmação é tão ousada que precisaria ser documentada com dados sobre mortalidade, temperatura no interior das casas e assim por diante. Sem tais informações, a afirmação é gratuita, muito provavelmente contrária aos fatos" (LEITE, 2007, p. 361). 
Ora, diferentemente do que ocorre com Bomfim, Paulo Prado e Caio Prado Junior, não há, nos textos de Freyre da década de 1920 e 1930, reflexão clara e sistemática sobre a questão do rigor e da linguagem investigativos. Dentre todos esses ensaístas, Freyre foi aquele que recolheu e mencionou o maior corpus de fontes primárias; foi o que apresentou as notas e referências bibliográficas mais gordas - e sempre revisadas. Talvez por isso, então, não lhe tenha parecido necessário discutir com o leitor as bases de rigor de suas proposições.

É então datado apenas de 1961 um prefácio a Sobrados \& mucambos, no qual Freyre defendeu largamente a precisão de suas colocações. Ali afirmou, não sem ironia, que "as antecipações do intérprete sociológico ou psicossociológico de algum trecho mais representativo de experiência ou de natureza humana têm sido acusadas, pelos objetivistas absolutos, de simples 'palpites', 'adivinhações', 'coisas de romance' ou 'poesia”'; mas que, contudo, conforme seu entendimento - aqui lembra bastante o que disse há pouco sobre as perspectivas de Bomfim, Paulo Prado, Caio Prado Junior -, "se das ciências, em geral, não é possível afastar o hipotético, a necessidade de hipóteses aumenta nas ciências sociais". Formular "interpretações", "compreensões" sobre um povo, afinal, lhe parecia requerer o estabelecimento conexões entre informações, num processo necessariamente pautado em larga erudição e forte intervenção subjetiva. Assim sendo, nesse caso, por fim, a "eloquência dos números" seria limitada e limitadora (FREYRE, 2004, p. 51).

Tal como Freyre, Holanda, em Raízes, ou em outros textos por ele publicados ao longo da década de 1930, não se abriu claramente a um diálogo com seus leitores, a respeito dos regimes de elaboração de verdade vigentes; ou a respeito de seu posicionamento, ante eles. Tal como Freyre, Holanda pareceu, nesse âmbito, restringir-se tão somente à preocupação de mencionar as mais variadas fontes documentais consultadas.

Mas quando tratou de sua opção metodológica por empregar "tipos sociais", Holanda o fez lembrando bastante os argumentos de Bomfim, Paulo Prado e Caio Prado, sobre a subjetividade nas reflexões sobre os modos de ser e pensar dos homens e das sociedades humanas. Conforme mencionei no Capítulo anterior, em Raízes Holanda afirmou que os "tipos sociais" ajudariam os investigadores "a situar e a melhor ordenar o conhecimento dos homens e dos conjuntos sociais" (HOLANDA, 1999, p. 45). Em outras palavras, assim indicou que os "tipos sociais", como explícitas formulações, ajudariam os pesquisadores a melhor definir e clarear, para seus leitores, as perspectivas a partir das quais observavam as fontes. Como sugeri antes, é justamente nesse ponto que Raízes remete a textos de Weber e Simmel: não tanto por compor tal e qual "tipo"/conceito, mas por compreender que os 
investigadores, longe de críticos imparciais, eram peça fundamental na elaboração da crítica sociológica.

Quando se referiu a grupos de intelectuais de sua época, Holanda os criticou sobretudo pelas dimensões políticas de suas concepções, e não tanto pelos regimes de verdade cumpriram e advogaram. Contudo, nisso deixou transparecer algo mais: sobre os teóricos inspirados pelo Romantismo, por exemplo, pontuou que propuseram "nada de verdadeiro, tudo de belo, mais arte que ciência, mais cúpula que alicerce" (Idem, p. 163). Na abordagem dos positivistas e "mussolinistas", ele se aproximou bastante das argumentações de Bomfim, acima aludidas, e sugeriu que esses intelectuais brasileiros, embora pretensamente precisos, estariam condicionados a convicções e compromissos políticos reduzidos e redutores (Idem, p. 158 e 187): disse que os positivistas "viveram narcotizados por uma crença obstinada na verdade de seus princípios" (Idem, p. 159), e que os mussolinistas eram "doutrinadores" “truculentos" e "desabridos" (Idem, p. 187).

Cabe agora refletir a respeito de como todos esses ensaístas brasileiros - tendo em vista tais aportes teóricos - abordaram o homem nacional: como raça, como psicologia, como cultura? Eu diria que o fizeram de uma forma pretensamente distinta do que vinha sendo comum, entre nossos cientificistas, e antecipadora do que fariam os sociólogos e historiadores especialistas e acadêmicos, de gerações posteriores: desdobrada do biológico, e para consideração de características concebidas a partir da experiência histórica, e do convívio social, econômico, político e cultural, entre indivíduos e povos.

No prefácio à primeira edição de Evolução política do Brasil, Caio Prado definiu que ali optara por empregar um "método relativamente novo - a interpretação materialista" (PRADO, p. 7). Segundo Francisco Iglésias, tal obra "na primeira e segunda edições aparecia [inclusive] com o subtítulo Ensaio de Interpretação Materialista da História Brasileira, para indicar a originalidade (IGLÉSIAS, p. 7).

Por metodologicamente novo, original, Marisa M. Deaecto lembra que, no período histórico por mim privilegiado nesta Tese, quer dizer, a década de 1930, Evolução política do Brasil não conquistou considerável repercussão. Ele ganharia expressividade, no cenário intelectual brasileiro, na década de 1940, no bojo da publicação do livro de Caio Prado que Candido considerou mais importante - Formação do Brasil contemporâneo (1942) -, e num contexto em que o materialismo histórico já possuía plena aceitação entre acadêmicos brasileiros (DEAECTO, 2007).

Isso não implicou, contudo, que Caio Prado deixasse de se interessar pelos modos de ser específicos do brasileiro. Conforme Márcia R. Victoriano, em Evolução política do Brasil 
ele considerou sim tal aspecto: o fez sob um enfoque "não-antropológico" (expressão que o próprio costumava utilizar); o fez sob a pretensão de compreender a formação do Brasil como "sociedade civil" (para utilizar um termo hoje corrente e que Victoriano adota) (VICTORIANO, 2001).

Num mesmo percurso interpretativo, André Botelho sugere, pois, que, "Caio Prado entendeu que o processo de colonização acabou por permitir que se esboçasse no Brasil uma nacionalidade diferente do modelo europeu e relativamente nova em termos sociais" (BOTELHO, p. 54).

Embora fizesse uso de vasto vocabulário cientificista - tão em voga na época Bomfim apresentou severa crítica às teorias de base biológico-raciais, que definiam nossos problemas latinoamericanos - no âmbito político, econômico, comportamental - como constitutivos. Para ele, compreender o "complexo" e "vivo" todo social a partir de um suposto fundamento único - a formação étnica - era "estreito" (BOMFIM, p. 57).

Em crítica aos teóricos biologicistas, escreveu:

Darwin nunca pretendeu que a lei da seleção natural se aplicava à espécie humana, como o dizem os teoristas do egoísmo e da rapinagem. (...) 'Luta pela vida' quer dizer, para ele, (...) esforço para conservar a vida e propagála, e não, simplesmente, (...) agressão cruenta (BOMFIM, p. 275).

Dante Moreira Leite considerou, entretanto, que ainda assim "Manuel Bonfim [sic] não se libertara da ideia de transmissão de traços psicológicos" (LEITE, p. 336). Efetivamente, pensando deslocamentos históricos, ele se perguntara: "Em que consiste a hereditariedade social?” E respondera: “Consiste na transmissão, por herança, das qualidades psicológicas, comuns e constantes, e que, por serem constantes e comuns através de todas as gerações, dão a cada grupo social um caráter próprio distintivo” (BOMFIM, p. 172).

Mas note que essa herança não tem, em Bomfim, nada de automático, natural, ou definitivo. Estudar o passado seria, a seu ver, importante na medida em que assim podemos visualizar "como nasceu, como se formou, naturalmente e logicamente, e como vem de longe" nosso modo de ser (Idem, p. 228).

De seus conhecimentos científicos à proposta de decompor verdades instituídas, de seu desejo por perceber múltiplos fatores que intervieram no devir histórico latino-americano, Bomfim compôs uma metáfora que lhe ajudasse a melhor explicar a situação histórica, coletiva - viva e complexa - da América Latina: a metáfora do "parasitismo".

Em América Latina: males de origem, ele escreveu: "Eis um princípio fundamental - e corriqueiro - em Biologia: que a função faz o órgão. Quer dizer, o exercício constante de um órgão aperfeiçoa-o, desenvolve-o, adapta-o de mais em mais à função; modificando-o, 
transforma-o"; o caso dos seres parasitas, acostumados a sugar energia e depender de condições alheias, a condição seria, então, a atrofia de algumas funções, ou mesmo a degeneração de alguns órgãos (Idem, p. 62-64).

Para ele, o mesmo sucederia com organismos sociais; caso específico dos ibéricos, que, aventureiros e imediatistas, ao colonizarem a América, teriam se dedicado a construir pouca coisa, e se conformado ao ócio e a um pensamento limitado e conservador (BOMFIM: 120).

Ademais, propôs Bomfim, - tanto no caso de organismos biológicos, quanto no caso de organismos sociais - o "parasitado" não apenas se "enfraquece", se "esgota", "sofre (...) pelo excesso de trabalho e deficiência de alimentação"; para Bomfim ele se "adapta às condições de vida que lhe são impostas", acostuma-se à "coação" e "deixa-se espoliar" (Idem, p. 135-136).

O leitor atento se dará conta, pois, de que entre a opção de Bomfim por trabalhar com a metáfora do "parasitismo" e a opção de Holanda por trabalhar com "tipos sociais", há muito em comum. Esses dois autores compartilharam, cada qual em seu ensaio, diversos entendimentos sobre a história e o presente brasileiro, mas, para mim, o essencial, é que ambos partiram desses conceitos genéricos para buscar compreender nuances e continuidades, na formação do Brasil como nação moderna. Parafraseando Holanda, eu diria, então, que: é claro que, em estado puro, não existiu um "português-parasita", nem o "homem cordial" possui existência real fora do mundo das ideias; mas também não há dúvida de que como extensão superindividual essas noções assumem, em América Latina: males de origem e em Raízes do Brasil, um referencial analítico de importância inestimável.

Dante Moreira Leite também criticou em Retrato do Brasil o recorte, psicologizante. A seu ver, Paulo Prado, como psicólogo social do povo brasileiro, consideraria que “impulsos" e "obsessões" teriam sido o estopim e combustível da conquista da América e da colonização do Brasil (LEITE, 2007, p. 346-347). Apontaria, ainda, determinadas características gerais comportamentais dos lusos seiscentistas como "herdadas" pelos brasileiros, através dos séculos (Idem, p. 350).

A respeito de tais perspectivas, Leite argumenta: "parece tão frágil e incoerente que talvez fosse desnecessário discutir". Por um lado, tal esquema, para ele, "evidentemente" não é "válido [tampouco] na psicologia individual" - haveria diversos fatores, para além dos humores, que condicionariam nossas ações no mundo. Por outro lado, para ele, "seria absurdo [considerar] uma hipotética psicologia coletiva” (Idem, p. 350). 
E fato é que, ao tratar do ser humano, em Retrato do Brasil, Paulo Prado de muitas maneiras se aproximou dos teóricos cientificistas, evolucionistas, que focavam a "natureza" dos indivíduos e das raças, e do ambiente, buscando definir uma psicologia coletiva - para usar um termo seu: uma "psicologia das populações", uma "psique nacional” (PRADO, 2001, p. 143 e 193). Em determinados momentos do ensaio, ele chegou mesmo a empregar a expressão "psique racial” (Idem, p. 141).

Porém, tal ensaísta falou ainda em "consolidação da raça" (PRADO, 2001: 195), quer dizer, aludiu a um processo de elaboração do "caráter brasileiro"; um processo que se desdobraria no tempo (Idem, p. 139). Nesse movimento da vida, para Paulo Prado, lembrando Bomfim, comportamentos, vivências e convivências seriam, afinal, os fatores mais fortes e definitivos na composição de modos de sentir e perceber o mundo; e não algo inato - por essência transcendente ou fundamentação natural.

O caso brasileiro seria, aliás, bastante ilustrativo da maior relevância dos fatores históricos, sobre os "naturais". Segundo Paulo Prado, Henry Thomas "Buckle diria que as diferenças de clima explicam as várias modalidades de temperamento. Países de luz e calor influindo na psicologia das populações; névoas de escuridão de invernos rigorosos dando uma feição tristonha aos homens de terras frias". Porém, "apesar do esplendor da Natureza", "no Brasil o véu da tristeza se estende por todo o país” (PRADO, 2001, p. 143).

Ademais, quando abordou a questão dos contatos entre povos - o branco, o índio, o negro -, no Brasil, fez questão de definir que foi ponto nodal de nossa história não tanto a "mescla de sangue" mas a maneira como o branco tratou os indígenas e africanos, sob o prisma fundamental do "relaxamento dos costumes" (Idem, p. 150); era a "praga da escravidão" que teria "corrompido" nossa psicologia nacional desde a base (Idem, p. 153).

Se considerarmos os ensaios de Bomfim e Paulo Prado, contrapostos ao de Holanda, resulta, porém, uma maior semelhança entre Raízes e América Latina: males de origem, do que com Retrato do Brasil. O digo porque o conceito central trabalhado nesse último corresponde a um dado psicológico; enquanto os conceitos centrais dos outros, não.

É verdade que o termo que Holanda utiliza para tanto - "cordialidade" - pode nos levar a crer que era justamente isso que ele tava fazendo: tal como Paulo Prado - que fala em "tristeza" -, ele estaria reduzindo o brasileiro, em sua diversidade, a um sentimento único, característico. Porém, como viemos acompanhando desde as primeiras seções do primeiro capítulo desta Tese, mais do que simpatia, bondade e bem querer, "cordialidade", em Raízes, corresponderia a um complexo conceito, e se aplicaria mais a relações sociais do que a um estado psicológico pontual. "Cordialidade", no ensaio de Holanda, remetia menos a uma 
simpatia constitutiva do que ao desejo de se mostrar simpático, e assim obter vantagens; menos a uma afetividade característica do que à prática de beneficiar, haja o que houver, os familiares e amigos.

Já vimos que Holanda pode não ter sido suficientemente claro, em Raízes, no que diz respeito a sua influências teórico-metodológicas; mas que, hoje, se supõe que teria sido influenciado sobretudo pela sociologia de Weber e Simmel.

Consideremos agora que, ao ver de Dante Moreira Leite, ao retornar dos Estados Unidos, Freyre trouxe na bagagem, "as últimas novidades em arte ou ciência, avidamente recebidas pelos provincianos" conterrâneos; novidades sobretudo da área de Sociologia, "na época, nada conhecida no Brasil”, mas cuja importância, para suas próprias reflexões, ele não chegou a sistematizar, no corpo de seus primeiros ensaios publicados (LEITE, 2007, p. 356).

De tudo que leu e trouxe como referência, diz Leite, "não é fácil identificar [em Casagrande \& senzala, de 1933, ou em Sobrados \& mucambos, publicado três anos depois] quais são as teorias fundamentais" (Idem, p. 361). Para Darcy Ribeiro, aparentemente, "simplesmente não há método nenhum", "nenhuma tese a que [Freyre] tenha sido fiel" (RIBEIRO, 2001, p. 27).

Ribeiro identifica, contudo, na multiplicidade confusa dos referenciais de Freyre, uma dada "herança do velho F. Boas" (Idem, p. 21).

Como nos contou o próprio ensaísta pernambucano, no aludido Prefácio a Casagrande, o mencionado antropólogo norte-americano havia sido seu professor desde os primeiros anos de sua estadia, no país estrangeiro. A admiração teria sido instantânea, e transformadora: "Aprendi [com ele] a considerar fundamental a diferença entre raça e cultura; a discriminar entre os efeitos de relações puramente genéticas e de influências sociais, de herança cultural e de meio" (FREYRE, 2001, p. 44).

Segundo Leite, contudo, Freyre teria dado “à raça um peso 'psicológico' maior do que o suposto por Boas" (LEITE, 2007, p. 361-362).

E é verdade que ele considerou aspectos psicológicos, e também aspectos raciais; tal como Paulo Prado, falou em uma "psicologia de raças" ou "psicologia de povos" (FREYRE, 2001, p. 44).

Todavia, não era a intenção primeira de Freyre apresentar tais definições; ou reduzir a análise do brasileiro a tais circunstâncias. Retomando passagem do Prefácio de Casa-grande dantes transcrita, eu proporia que o raciocínio de Freyre se estruturou sempre sobre três bases: "raça" ou "relações genéticas", "efeitos do ambiente" ou "meio", e "experiência cultural” e/ou "heranças culturais". Essas três bases se revelam igualmente importantes e necessárias em 
seus textos. E foi sobre todas elas que teria desfilado o que Freyre concebeu como a originalidade do homem brasileiro: o tipo miscigenado, que nos trópicos, a partir de tais e quais possibilidades e relações, construiu a casa-grande, a senzala, o sobrado e o mucambo.

A meu ver, afinal, Freyre se percebia não como um investigador da psicologia brasileira, mas como um escritor-antropólogo, como um escritor-sociólogo - como um investigador deslumbrado ante as diversidades que caracterizam os homens e suas relações, no Brasil. No prefácio a Casa-grande \& senzala definiu-se como "estudioso da formação patriarcal e da economia escravocrata do Brasil” (FREYRE, 2001, p. 44). No prefácio à primeira edição de Sobrados e mucambos, como um pesquisador interessado em "reconstituir e interpretar certos aspectos mais íntimos da história social da família brasileira" (FREYRE, 2004, p. 27).

Freyre, destarte, tal como Bomfim e Paulo Prado, falava do Brasil como um complexo civilizacional novo: não apenas distinto, ou inferior, ou deturpado, se em relação a padrões estrangeiros; mas novo.

Em Casa-grande \& senzala, Freyre diferiu o português do luso-brasileiro. Apresentou o primeiro, como estrangeiro e estranho, além de tipicamente mercantil; e o outro, apoiado no braço negro, como rural. A ruralidade do segundo, sua fixação, seu ordenamento, sua coesão, sua convivência com o africano feito escravo, teriam configurariam, afinal, um modo de ser e viver único, autêntico, incomparável.

Num mesmo sentido, sobre civilização como fixação, Freyre apontou - ainda em Casa-grande \& senzala, como outro importante e singular elemento social/cultural do Brasil Colônia, as corporações religiosas. Conforme seu entendimento elas teriam representado uma força de sedimentação, de fixação, e de associação com o braço indígena antes mesmo do senhor proprietário, de fazendas e de negros (Idem, p. 295).

Por fim, num sentido inverso, mas ainda sobre a fase colonial do Brasil, Freyre propôs como pouco "novo" ou pouco "brasileiro" (ou, ainda, ambas as coisas) o "mestiço de índio com português", caracterizado por certa "tendência (...) para a mobilidade" (Idem, p. 301).

Em Casa-grande \& senzala Freyre destacou, ademais, a excepcionalidade do Brasil colonial, por contar com a contribuição de referências culturais os mais diversos: lusos, em sua múltipla composição étnico-cultural, negros das mais distintas regiões da África, índios das mais variadas tribos. E, diferente dos românticos ou dos teóricos concentrados em denegrir nossa condição, apresentou características positivas e negativas que supunha típicas de todos eles; das mais inusitadas às mais convencionais. 
Em Sobrados \& mucambos Freyre, porém, ele passou a abordar um período da história brasileira que ele considerou mais complicado, porque mais aberto a imposições e deformações culturais vindas unilateralmente da Europa branca. Destacava-se, entretanto, em meio às instabilidades do Brasil oitocentista, um elemento novo e muito tipicamente nacional: o mulato intelectualizado- etnicamente e culturalmente híbrido, criativo.

Se voltarmos a Raízes, podemos ficar inseguros quanto à afirmativa de Holanda, no que diz respeito à "novidade" da civilização brasileira. Como vimos, sua escrita não é tão afirmativa quanto à de Freyre, e as variações entre os textos das diversas edições de seu ensaio são muitas, e confundem. Porém, creio que, apesar de não ser consensual entre seus intérpretes, se, ali, a colonização lusa da América é apresentada como um grande feito ou equívoco, me parece indiscutível que nosso país é desenhado como uma composição social, em última instância, nova.

Eu diria, então, que mais do que sublinhar que Freyre observou como positiva a tarefa civilizatória portuguesa, e Holanda não, questão mais interessante seria o fato de que, para o autor de Raízes a originalidade brasileira ainda não havia sido completada; e, para o autor de Casa-grande \& senzala e Sobrados \& mucambos, ela tinha se dado na colonização, mas se esvaía, com o passado dos anos.

Rugai Bastos assinala, então, em análise comparada de Raízes e Sobrados \& mucambos: enquanto no primeiro desses ensaios o ambiente urbano o patriarcado - herança portuguesa - aparecesse impedindo avanços, no sentido de um Brasil mais justo e mais livre; no segundo, a vida nas cidades representava a decadência do patriarcado - herança portuguesa fundadora. Em análise de um mesmo movimento histórico, logo, o primeiro expressava o lamento ante continuidades históricas, e o segundo, ante as rupturas (BASTOS: 233). 


\subsection{O ensaísmo mexicano}

Não nos restam muitos registros (depoimentos, entrevistas, ou testemunhos) nos quais Ramos tenha marcado seu engajamento ou rompimento - ainda que fortuito e circunstancial com algum movimento filosófico, estético ou político; do que resulta não ser nada simples avaliar conexões entre as ideias e métodos propostos em El perfil, e ideias e métodos propostos por outros intelectuais e políticos mexicanos, daquelas primeiras décadas do século XX.

As dificuldades se ampliam porque são poucos os estudiosos de Ramos e El perfil (no Brasil, ou mesmo no México) que trabalharam em investigações históricas amplas, focadas, sistemáticas, sobre esse universo de questões.

Nas biografias de Ramos, dois dados, dos quais aqui podemos partir, são apresentados, de forma unânime, como fundamentais na formação intelectual de Ramos: por um lado, tal como Holanda, ele iniciou sua trajetória escrevendo artigos de crítica em periódicos de maior ou menor repercussão, no México; por outro, distintamente, pronto ingressou num curso de Filosofia, e nessa oportunidade foi aluno de grandes expoentes do pensamento mexicano de então.

Em revistas de Filosofia e Arte e na universidade, pois, podemos considerar que esse autor mexicano esteve em contato com uma ampla gama de entendimentos e de formas de entendimento acerca do México, suas tradições e modernidades; conheceu, foi influenciado e influenciou muitos expressivos professores, escritores, críticos, agentes culturais, e políticos da época.

Importante fazer notar aqui que, diferente do Brasil, o México tinha há muito sua tradição universitária: a Real y Pontificia Universidad de México, por exemplo, foi fundada ainda no período colonial, por grupos religiosos espanhóis. Porém, os pensadores de projeção quando Ramos começou a se interessar por Filosofia, quase todos, haviam se formado nos disponíveis cursos de Direito, Medicina e Engenharia; não foram filósofos especialistas desde o princípio de suas carreiras intelectuais, como o futuro autor de El perfil viria a ser. Como exemplo, podemos mencionar que os futuros influentes professores de Filosofia Antonio Caso e José Vasconcelos haviam se formado advogados/jurisconsultos.

O novo universo de possibilidades, do qual dispôs Ramos, foi aberto, no início do século XX, por iniciativa de Justo Sierra. Secretario de Instrucción Pública y Bellas Artes do ditador Porfírio Díaz, Sierra planejou e reuniu diversas faculdades de importância na capital (como a Escuela de Jurisprudéncia, a Escuela de Medicina e a Escuela de Ingenieros) em 
torno de um centro filosófico, de orientação positivista, a Escuela de Altos Estúdios: assim criou a moderna Universidad Nacional de México (HERNÁNDEZ, 1982).

Paralelamente, Sierra e seus encarregados não apenas concederam financiamento a ousadas iniciativas estudantis, contrárias ao positivismo ditado pelo governo de Porfírio Díaz; eles apoiaram que os debates a respeito fossem desenrolados no seio da própria universidade.

O México foi pensado, àquela época, de maneira informal, generalista, crítica e subjetiva, por nomes representativos do que viria a ser a grande e profícua moderna tradição ensaística mexicana. Dela são expressivos os trabalhos de dois grupos: o Ateneo de la juventud (do qual fizeram parte os já citados Caso, Vasconcelos, além de Pedro Henriquez Ureña, Alfonso Reyes, entre outros); e Los siete sábios (do qual fizeram parte Vicente Lombardo Toledano, Manuel Gómez Morin e o irmão de Antonio Caso: Alfonso Caso).

Fernando Curriel Defossé, em belo artigo, nos conta que no ano de 1908 estudantes da Universidade Nacional passaram a trabalhar na edição de uma revista nova, a Savia moderna. Em 1907 esse mesmo grupo de jovens, e novos apoios, fundaram uma Sociedad de Conferéncias, e passaram a organizar palestras, para um público bastante variado, tornandose, então, célebres não apenas no círculo universitário. Segundo esse historiador, apenas em 1909, sob direção de Antonio Caso, eles passaram a se denominar "Ateneo de la Juventud"; e em 1910, sob coordenação de José Vasconcelos, conceberam uma espécie de comissão, que chamaram "Universidad Popular", encarregada de, paralelamente ao projeto de Sierra, voltar a planejar eventos dedicados à difusão de informação e reflexão filosófica (CURRIEL DEFOSSÉ, 1998).

Dos pensadores envolvidos em tais movimentações, nesta Tese concederei foco sobretudo ao chilango Antonio Caso, e ao oaxaqueño que viveu quase toda infância e adolescência em Coahuila, José Vasconcelos, porque, conforme os biógrafos de Ramos, foi com eles que o autor de El perfil mais conviveu nos primeiros momentos de sua formação.

De Caso, tomarei Discursos a la nación mexicana, (1922 - com textos publicados na imprensa daquele país no ano de 1917), El problema de México y la ideología nacional (1924 - com artigos produzidos entre os anos de 1922 e 1924) e Nuevos discursos a la nación mexicana (1934 - com textos de 1924 a 1933). De Vasconcelos, especialmente considerarei La raza cósmica (1925) e Ulises criollo (1936).

Importante aqui dizer que é bastante comum pontuar-se que, passada a fase dos conflitos armados em oposição a Díaz, na década de 1920, Caso e Vasconcelos trabalharam para o governo do general revolucionário Álvaro Obregón. É bastante comum se dizer que ambos defenderam, então, o estudo do nacional como peculiar, como autêntico, contribuindo 
para a elaboração de uma identidade referencial para o mexicano moderno. Que contaram, naquele momento, com um considerável apoio estatal, e que, se já eram relativamente famosos, seus trabalhos então ganharam enorme respeitabilidade, vindo a alcançar muitos dos futuramente mais expressivos intelectuais mexicanos, dentre os quais Ramos. Essa é, por exemplo, a visão de Roger Bartra.

Mas estudos recentes vêm defendendo que o Ateneo não correspondeu a um grupo por princípio politicamente engajado, ou que Caso e Vasconcelos estabeleceram, os dois, vínculos idênticos com o Estado "revolucionário". Não há base para se sustentar, tampouco, que cada qual se relacionou, por toda a vida, da mesma forma, com os grupos no controle da política desde os conflitos denominados "Revolução mexicana".

A ilustre professora Maria del Carmen Rovira Gaspar se inclui entre os críticos que têm apontado como uma tendência errônea da interpretação marxista - que para ela partiria de Vicente Lombardo Toledano, e que considero incluir Bartra - desenhar-se o grupo ateneísta como um grupo homogêneo e comprometido com os presidentes auto-denomiados "revolucionários", na composição de uma identidade nacional. Segundo Rovira - vivaz organizadora de um grupo de pensadores da UNAM interessados na Filosofia produzida no México; dentre os quais Zagal e Hurtado - “los ateneístas nunca ‘forjaron' y tampoco les interesó hacerlo, el ideario de la Revolución” (ROVIRA, p. 309).

Eu lembraria, nesse sentido, algumas notáveis continuidades e/ou correlações entre as iniciativas dos ateneístas e o governo que antecedeu a revolução. Em primeiro lugar, de algo que acabei de pontuar: as iniciativas do grupo que viria a ser denominado Ateneo de la Juventud começaram contando com apoio de um funcionário da administração do ditador Porfírio Díaz, quer dizer, Justo Sierra. E acrescentaria que Ramos, como discípulo de ateneístas, não deixou de render homenagem, em edições posteriores de El perfil, ao célebre secretário porfirista como importante promotor cultural, como precursor de fundantes (e, a seu ver, revolucionários) projetos educativos.

A propósito, Rovira nos informa, especificamente sobre Caso, que esteve vinculado ao Club Reeleccionista, que em 1910 advogou pela nova candidatura e eleição de Porfírio Díaz para um sétimo mandato; e não por Francisco Madero, que pregava "sufragio efectivo y no reelección". E que Vasconcelos chegou a declarar, em suas memórias, que o colega, "en privado, nos hacía la defensa [del dictador], lo juzgaba el mal menor de un pueblo inculto, sin esperanza" (Apud. ROVIRA, p. 306).

Alejandro Estrella González afirma que, quando Vasconcelos foi secretário de Educación Pública do governo revolucionário, entre os anos 1921 e 1923, enfrentou a 
dissidência de Caso, que ele escolhera para reitor da Universidade Nacional. De acordo com esse pesquisador havia, afinal, entre os dois renomados ateneístas, uma tensão difícil de se equilibrar: de um lado "una universidad que aspiraba a ganar cuotas de autonomía y conservar su esencia liberal (Caso)" e de outro lado "intereses encontrados de un Estado revolucionario que pretendía subordinar los objetivos de la universidad a los objetivos de la Revolución (Vasconcelos)" (ESTRELLA GONZÁLEZ, p. 326.).

Lembre-se, pois, que a questão da autonomia universitária só foi solucionada no Maximato, quer dizer, entre as décadas de 1920 e 1930; sob a anuência de Plutarco Elías Calles, a presidência de Emilio Portes Gil, e a iniciativa do secretário de Educación Pública Moises Sáenz (ao qual me referirei adiante). Só então a Universidade Nacional Mexicana passou a ser UNAM: Universidad Nacional Autónoma de México (MEDÍN, p. 160).

Caso, que sempre defendera a independência da tomada de decisões pelos professores e estudantes da dita instituição, a respeito de questões organizacionais e pedagógicas, lamentou, então, profundamente, quando em 1934 professores marxistas, dentre os quais o já citado Lombardo Toledano, passaram a pregar um direcionamento total, socialista, às práticas de ensino e pesquisa. Lhe parecia, afinal, uma afronta à autonomia universitária conquistada a duras penas, assim como aos princípios liberais de que parecia beber - de maneira que, por aqueles anos, publicou a respeito inúmeros artigos críticos.

De porfirista a liberal, precisamos ter em mente, então, que Caso não apresentou, ao longo de toda sua vida, reflexões que partiam de um mesmo ponto de vista. Conforme Abelardo Villegas, as obras de Caso compõem, decerto, um conjunto "incongruente" (VILLEGAS, p. 35).

A meu ver, as alternâncias e diferenças de proposições são muitas, mas é possível visualizar algumas tendências gerais: da década de 1910 à década de 1920, e dessa última à de 1930, há, na argumentação de Caso, um movimento que vai da busca de um novo método filosófico a uma maior preocupação com o delineamento de uma Filosofia nacional. Para demonstrar como isso ocorre, efetivamente, tomo para análise agora, en passant, aplicações feitas por Caso do termo "individualismo"; o que deve nos ajudar a entender melhor as perspectivas políticas desse pensador mexicano.

Em artigo de 1917, Caso argumentava que o "individualismo" havia sido muito criticado pelos positivistas, que observavam temerosos a noção de "anarquia". Ele dizia, então, compreender que, tanto uma coisa como outra - individualismo e anarquia -, eram positivas, sobretudo em se tratando de produção intelectual. Na Filosofia, a seu ver, individualizar-se era o mesmo que libertar-se; e a anarquia daí decorrente nada mais era do 
que o estabelecimento de uma rica diversidade de pontos de vista (CASO, p. 47). Caso criticava, pois, o positivismo porfirista, por pretender-se científico e geral, mas revelar-se, tantas vezes, base para configurações anti-individualistas e egoístas, pretensiosas e redutoras (CASO: 57).

Anos mais tarde, porém, ele passou a empregar o termo "individualismo" num outro sentido; equivalendo, mais propriamente, a "egoísmo" e descaso para com a coletividade. Após ser reitor da então Univerdidad Nacional de México, em artigo de 1924 sugeriu, a respeito de seus conterrâneos: "nuestro individualismo exaltado, nos aísla de nuestros sentimientos semejantes y nos aparta de nuestros prójimos, de nuestros hermanos" (Idem, p. 89); “todos queremos el primer lugar y maldecimos de los que lo ocupan” (Idem, p. 90).

Aqui convém pontuar que desconheço trabalhos que considerem possíveis interesses de Caso pelas doutrinas totalitárias, em plena difusão, tanto na Europa como na América, nas décadas de 1920 e 1930. Muito pelo contrário, o trabalho do professor José Hernández Prado foca artigos de Caso publicados nos anos 1940, como El peligro del hombre, nos quais Caso apresentaria a busca da liberdade como o propósito do homem na história (HERNÁNDEZ PRADO, p. 161).

Entretanto, temos que nos anos 1930 Caso divulgou diversos textos críticos, que denotavam clara simpatia por concepções totalitaristas. Transcrevo, aqui, pequeno trecho de um deles, que me parece suficientemente ilustrativo e indubitavelmente confirmativo do que estou propondo. Nele escreveu Caso: "Nuestra revolución tiene um perfil próprio, y debe desembocar en un gobierno enérgico de amplio sentido social; en un 'nacionalismo social'. Esto es lo que ha realizado en Italia Mussolini, lo que hoy pretende lograr Hitler en Alemania" (CASO, p. 111).

Ora, Caso e não Vasconcelos foi professor de Ramos, mas, ao que tudo indica, politicamente Vasconcelos apresentou concepções políticas mais próximas às de Ramos.

Conforme Basave, Vasconcelos "no le dió clases a Ramos, pero fue su maestro en más de un sentido" (BASAVE, p. 10). Secretário da Instrucción Pública ao longo de quase todo o mandato de Obregón, ele foi amigo de Ramos por toda a vida. Contou com Ramos em diversos projetos culturais, na referida secretaria, dentre os quais as Lecturas clásicas para niños e as Lecturas para mujeres (ARREOLA, p. 99). E o ex-pupilo de Caso participou, ainda, de seu projeto de tradução de textos-base da filosofia universal, para o espanhol; junto a Daniel Cosío Villegas e a Eduardo Villaseñor (que futuramente fundariam o editorial Fondo de Cultura Económica), ele trabalhou sobre uma versão francesa de Enéadas, do filósofo 
grego Plotino. Também editou, junto a Vasconcelos, a revista Antorcha (HERNÁNDEZ LUNA, 1982, p. 98).

Segundo Rosa Helena Pérez de la Cruz, enquanto trabalhou para Obregón, "Vasconcelos aparece como un colaborador en la construcción de un Estado bonapartista y en la creación de uma ideologia nacional-populista; (...) un Estado de corte popular, nacionalista y plural” (PÉREZ DE LA CRUZ, p. 326). Porém, segundo Federico Lazarín Miranda, de fato ele "encontró difícil conciliar su condición como pensador independiente con las exigencias de los cargos de gobierno que ejerció (LAZARÍN, p. 13).

Importante destacar nesse sentido, ademais, que, como destaca Abelardo Villegas, se os primeiros livros de Vasconcelos foram escritos sob uma visão um tanto mais positiva do projeto obregonista, Ulises criollo foi escrito já quando estava no poder Calles, El Jefe Máximo, e em vigor a lógica do Maximato; aí então, Vasconcelos já se havia decepcionado com o Estado Revolucionário. Nota-se claramente, entre o período que separa a publicação de Raza cósmica e Ulises criollo, portanto, uma transição da fé na política, ao pessimismo crítico (VILLEGAS, p. 66).

E quanto aos flertes de Vasconcelos com o ideário totalitarista? Poderíamos dizer que em certa medida se aproxima do que propus a respeito de Caso?

Itzhak Bar-Lewaw Mulstock, um dos grandes especialistas no autor de La raza cósmica e Ulises criollo, em conferência de 1982, confessou:

Al publicar mi libro en 1965 y 1966 no sabía que José Vasconcelos - el tan llamado Maestro de la Juventud Lationamericana (...) - durante la Segunda Guerra Mundial, en 1940, entre los meses de febrero y junio de aquel año, (...) era un agente de la propaganda nazi-hitleriana de la peor especie (BARLEWAW, p. 151).

Porém, creio que podemos considerar que tal julgamento não se aplica ao Vasconcelos que aqui, nesta Tese, interessa: o animado Vasconcelos que dirigiu a Secretaria de Educación Pública de Obregón, e talvez tampouco o desiludido autor de Ulises criollo.

Entre uma coisa e outra, quando candidato à presidência, em 1929, por exemplo, desconfiado de que seria vítima de um golpe, Vasconcelos declarou formalmente que não tomaria em armas, porque tal opção ia contra seus princípios políticos mais fundamentais. Vasconcelos, nesse sentido, ainda, portanto, partia de concepções liberais, e pontuava ser necessário basicamente investir em educação, para que a conscientização libertasse o país do atraso (MEDÍN, p. 165).

E Ramos? Como se posicionou, com relação a tais questões à época tão prementes? E como isso aparece no texto de El perfil? 
A meu ver, embora não constem, nem mesmo nos itens do arquivo pessoal de Ramos, doados ao IIF da UNAM, registros dos posicionamentos, digamos assim, "políticoideológicos" de Ramos, podemos dizer que esse autor compartilhou com Vasconcelos, na década de 1930, uma mesma visão crítica, no que diz respeito à política mexicana; no que diz respeito ao governo instituído, que se rotulava "revolucionário".

A leitura de El perfil denota clara inconformidade dele ante os direcionamentos dados pelo Maximato às políticas culturais e à educação pública. É também notável que determinadas práticas políticas mexicanas extremamente criticadas por Ramos, em seu ensaio, pudessem ser observáveis em figurões do México de então, sobretudo o próprio Jefe Máximo (RAMOS, c. 6).

Fato é que, depois de trabalhar para Vasconcelos, depois que Calles assumiu o controle da política mexicana, Ramos seguiu tento contato com funcionários do governo mexicano. Tornou-se funcionário da dita Secretaría de Educación Pública, sob coordenação de Narciso Bassols, no governo do também michoacano Abelardo Rodríguez. E, conforme Arreola, conseguiu, para algumas revistas literárias para as quais contribuía, subsídio do referido órgão (ARREOLA, p. 125). Foi também professor da Universidade Nacional.

Porém, como veremos, me parece claro que nem Vasconcelos, nem Bassols, nem Ramos foram em tudo subservientes aos estadistas revolucionários. Em primeiro lugar, os dois primeiros lograram negociar, respectivamente, com Obregón e Calles, seus programas educativos. Depois, mesmo que Vasconcelos e Bassols inspirassem admiração, por parte de Ramos, a relação entre secretários e funcionário se deu como cooperação e não dependência/imposição, entre chefes e encarregado.

Bassols, como veremos, foi um secretário ambicioso e polêmico, em seus planos, e, por isso, aos olhos de Ramos, problemático e interessante. Entretanto, nesse período, Ramos já era um pensador consagrado, com cuja reputação e capacidade intelectual era mais do que natural que o Estado e secretários desejassem contar. Sendo assim, integrar o grupo de Bassols não foi mais interessante para Ramos, do que a presença de Ramos no grupo, para Bassols.

Ademais, Ramos desde a época em que escreveu El perfil, até aquela em que foi professor da Universidade Nacional, essa já se encontrava em regime de autonomia de maneira; quer dizer, que seus compromissos com suas funções enquanto professor universitário prescindiam do cumprimento de normas ditadas pelo Partido revolucionário, ou pelo presidente, ou menos Jefe Máximo, por trás do presidente. 
Convém destacar, então, outra questão, relacionada a tais tramas político-ideológicas, do México de princípios do século XX. Qual seja: o fato de que em El perfil não há sequer uma referência ao fascismo ou ao nazismo. Não é intrigante que Ramos não tenha mencionado tais projetos político, em seu livro mais famoso?

Era de se esperar que abordasse concepções totalitaristas, em voga na Alemanha que ele conheceu em fins da década de 1920; que não escaparam a seus mestres; e que deviam causar desconforto em um país que vivera uma ditadura - a ditadura Porfirista - por mais de trinta anos. Ademais, era de se esperar que Ramos o abordasse, porque em seu ensaio tocou, criticamente, questões bastante caras aos nazifascistas, tais como: a política, o cumprimento das leis, o nacional, o racial.

A despeito do silêncio de Ramos em suas obras publicadas, seus biógrafos, dentre os quais Hernández Luna (1982) e Arreola Cortés (1984), como amigos que com eles conviveram, coincidem que por toda a vida ele teria defendido a liberdade política e de pensamento.

Importante sublinhar, logo, no que tange às perspectivas políticas de Ramos, que, embora próximos aos do Vasconcelos da década de 1930, me parecem haver sido críticas e portanto autênticas, independentes. Elas remetiam sim, creio, em grande parte, ao fato de o autor de El perfil ter sido companheiro fiel do aborrecido ex-secretário Vasconcelos; mas não hão de ter sido por tal fato absolutamente determinadas/ condicionadas.

Desde já pontuaria, como exemplo, que Ramos, ao referir-se com insistência, em sua célebre obra, ao descaso dos mexicanos com as normas políticas instituídas, poderia ter em mente não apenas a possível fraude das eleições de 1929, nas quais Vasconcelos apresentouse como candidato, e perdeu para Pascual Ortiz Rubio, homem de Calles. Nessa referência, ele poderia ter em mente também o desconforto ante ao fato de Ortiz Rubio, michoacano tal como ele, ter sofrido intensa pressão política por parte Calles, até que, em 1932, acabou renunciando.

Para fechar, por ora, tais delineamentos do posicionamento político de Ramos quando da elaboração de $E l$ perfil, e, ao mesmo tempo, introduzir a análise de outros aspectos também importantes para esta seção, eu diria que, diferentemente de Vasconcelos, Ramos assumiu uma perspectiva desconstrutora. Veremos seções adiante deste Capítulo, quando forem abordados os literatos mexicanos do período, que a revisão crítica das verdades políticas, assim como a crítica dos clichês da nacionalidade, foram bastante expressivas, nas reflexões de poetas e romancistas com os quais o autor de El perfil conviveu intensamente. 
Ora, diz-se que Caso foi o responsável por fazer com que Ramos abandonasse a Medicina, e optasse pela carreira de filósofo. Na interpretação de Paz tal ateneísta aparece não como um reacionário, mas como um professor inspirador de toda uma geração; em $E l$ laberinto lê-se, por exemplo, que seu "persistente amor ao conhecimento, que o fez prosseguir as aulas quando as facções se engalfinhavam nas ruas, transformou-o num belo exemplo do que significava a Filosofia: um amor que nada compra e nada muda" (PAZ, p. 127). E fato é que, como veremos no último Capítulo desta Tese, em inúmeros pontos seu raciocínio sobre o homem e a cultura do México moderno, Ramos remete a proposições dantes apresentadas por Caso.

Desde já, podemos considerar alguns pontos fundamentais; a começar por El génio español, artigo publicado por Caso na imprensa mexicana em 1917, e parte integrante de A la nación mexicana, compilação de 1922, no qual são apresentados conceitos-chaves de $E l$ perfil. Não me refero, pura e simplesmente, à consideração da matriz cultural latina, espanhola como fundamental - coisa que Vasconcelos igualmente pontuara em La raza cósmica. Refiro-me a algo muito mais importante: ao fato de que Caso inicia o referido texto tratando de método, de "psicologia de los pueblos" (CASO, p. 9).

Em El génio español Caso conta que, à época, muitos intelectuais mexicanos consideravam um "devaneo insierto" quaisquer considerações generalizadas sobre a psicologia de um agrupamento. Para esses críticos, "sólo es real (...) el individuo humano, (...) el ser personal concreto" (Idem, p. 9). Porém, não lhe parecia discutível que cada homem se elabora, como ser concreto, a partir de padrões largamente compartilhados e muito fortes (língua, crenças, tradições). Tampouco lhe parecia questionável que esses padrões de alguma maneira conformavam - não no concreto, mas no real abstrato - uma "nueva realidad psíquica", que possuía "contornos espirituales de un individuo, de una personalidad" (Ibidem).

Reflexões sobre a "psicologia coletiva de los pueblos" já haviam aparecido, en passant, em outros artigos, anteriores, de Caso, como El descobrimiento de América, de 1910. Nesse, o ateneísta rotulara os ditos críticos dos estudos de contornos psicossociais "escepticos pesimistas" (Idem, p. 18).

Ora, tais percepções não são algo como o transfundo da noção de "pelado", elaborada por Ramos? Essa articulação entre "indivíduo humano" e "personalidad" coletiva não se assemelha à articulação entre particular e geral, fundamental no "pelado", de Ramos? Como venho defendendo nesta Tese, o "pelado" correspondia a uma síntese, uma definição da 
psicologia geral mexicana; era ferramenta analítica, "ejemplar para estudio", “expresión más elemental" de um todo social mais complexo e que ia além dele (RAMOS, p. 119).

Outro ponto da argumentação de Ramos que, consciente ou inconscientemente, remete a artigos de Caso da década de 1910, e mereciam menção em uma nota de pé de página, em $E l$ perfil, é a ideia de que o mexicano esconde, com um dado comportamento, o que realmente é.

Em El bovarismo nacional, de 1917, Caso defendera que todo homem e mulher é um pouco como o personagem do romancista oitocentista francês Gustave Flaubert, Madame Bovary; que todo homem e mulher é, no fundo, um pouco "bovarista". Caso considerou nessa oportunidade, com o crítico Jules de Gaultier, que a característica mais marcante de Emma Bovary seria certa dificuldade de compreender sua própria natureza, seus próprios desejos e necessidades, suas qualidades. E, então, escreveu: "nos creemos pensadores y no lo somos; poetas, tal vez, y no somos poetas, mártires sublimes o santos redentores, y sólo en el delirio de nuestra fantasía redimímonos y nos santificamos" (CASO, p. 23).

A proposta, em tal texto, não era, contudo, restringir-se à psicologia individual; Caso saltava para fora do pessoal, do particular, e sugeria que os mexicanos como um todo eram "bovaristas": utópicos, idealistas, descuidariam da realidade à sua volta, do mundo no qual poderiam intervir e do qual poderiam desfrutar. Não é essa uma antecipação da noção proposta por Ramos, de sentimento de inferioridade e vulnerabilidade, por parte de um mexicano que, ao mundo, se manifesta como feroz e perigoso, não é mesmo?

Anos mais tarde, mais precisamente 1924, Caso voltaria a tal abordagem psicologizante, sugerindo que, como se fora um indivíduo, o povo do México, devido a tais e quais experiências, através dos séculos, se havia convertido em um povo deprimido, solitário. Escreveu, então: "Nuestras desventuras político-sociales nos han creado una estinmación inferior a la que merecemos" (Idem, p. 91).

Para tais problemas, Caso buscava uma saída filosófica. Em La existéncia como economía, como desinterés y como caridad (1906), propusera, por exemplo, haver, no comportamento humano, tendências para um viver coletivo que iria além do interesse material ou do alheamento; quer dizer, num tom religioso, ele apontava traços de humanidade, fraternidade, que deveriam ser pensados e intensificados, na prática. Assim, conforme Victor Manuel Hernández Uría, em Caso o pensamento se converte em ponto de partida para a ação transformadora (HERNÁNDEZ URÍA, p. 32).

Para esse intérprete, a psicologia mexicana não seria, afinal, ao ver do ensaísta ateneísta, uma essência; ela se formaria através da experiência, e poderia ser transformada, ao longo da história. O homem enquanto homem existiria "únicamente en interrelación con los 
conceptos de sociedad universal, de libertad, de cultura, de Estado, de los derechos humanos, es decir, con la cultura general, porque toda cultura implica la idea o cosmovisión que tiene el individuo de su mundo, de su sociedad, de su quehacer productivo" (HERNÁNDEZ URÍA, p. 19).

Daí que, ao ver de Caso, não houvesse um dado homem ou povo inferior; a questão da inferioridade o superioridade é sempre relacional. Para usar palabras de Hernández Uría, segundo tal filósofo, "un hombre es inferior si no está preparado y es superior cuando hace uso de su razón y su inteligencia” (Idem, p. 26).

Viés psicologizante, tensão entre teoria e prática, percepção de um dado complexo de inferioridade, e dimensão antropológica e histórica - eis aqui quatro bases da teoria de Ramos, sobre o homem e a cultura no México, apresentadas, sem qualquer clara referência positiva a Caso, em El perfil.

Quanto a Vasconcelos, fundamental destacar que, na década de 1920, além de pretender promover a cultura nacional e ampla alfabetização dos mexicanos, pela via estatal, como secretário de governo, divulgou a ideia de uma "raza cósmica", do livro que justamente levava esse nome na capa, e aqui já foi aludido. Basicamente, esse ateneísta propunha, na obra publicada em 1925, que, na América Latina, pela mistura amorosa das raças surgiria uma raça superior, uma "raça-síntese", que possuiria em si as qualidades espirituais de todas as outras por ser amplamente humana, nos dois sentidos dessa palavra (VASCONCELOS, 1948).

É, afinal, tal teoria a origem da frase inscrita no brasão da universidade de maior importância daquele país, a UNAM: "por mi raza hablará el espírito".

Ao ver de Vasconcelos, dos povos que colonizaram a nós, latinoamericanos, quer dizer, os brancos latinos, a "raça cósmica" herdaria: "genio y de arrojo", além de um generoso interesse pelo diferente. Para ele,

si fuese menester aducir pruebas, bastaría observar la mezcla creciente y espontánea que en todo continente latino se opera entre todos los pueblos, y por la otra parte, la línea inflexible que separa al negro del blanco en los Estados Unidos, y las leyes, cada vez más rigurosas, para la exclusión de los japoneses y chinos de California... (Idem, p. 65).

Vasconcelos, assim, apresentava uma severa crítica das teorias raciais em voga, e partia de um vocabulário comum a elas, mas propunha um olhar completamente distinto, para chegar a conclusões opostas. Logo no início de seu ensaio, pontuava:

La doctrina de formación biológica que en estas páginas anunciamos, no es un simple esfuerzo ideológico para levantar el ánimo de una raza deprimida, ofreciéndole una tesis que contradice la doctrina con que habían querido condenarla sus rivales. Lo que sucede es que a medida que se descubre la falsedad de la premisa científica en que descansa la dominación de las 
potencias contemporáneas, se vislumbran también, en la ciencia experimental misma, orientaciones que señalan un camino ya no para el triunfo de una raza sola, sino para la redención de todos los hombres (Idem. p. 12).

Eu diria, assim, que Vasconcelos como Caso teriam apresentado, para Ramos, em igual medida, um sentido novo ao pensamento mexicano: em primeiro lugar, a crítica da abordagem racial-cientificista, e compreensão do homem do México como um ser composto de matéria, psicologia, e história; a opção por, a despeito de utilizarem o termo "raça" em suas reflexões, jamais o terem feito condicionando a defeitos constitutivos (como era costume e amplamente aceito).

Em segundo lugar, despertado em Ramos o interesse pela mexicana, pelos modos de ser mexicanos, em suas dinâmicas próprias; e a valorização das dimensões espirituais, instintivas e intuitivas locais, em oposição ao cientificismo redutor do positivismo porfirista, e também em oposição ao materialismo capitalista, moderno, característico dos discursos de Calles e seus sucessores, os presidentes do período denominado Maximato.

Ainda assim, fato é que Ramos seguiu sendo amigo de Vasconcelos, mas rompeu publicamente com Caso, em meados da década de 1920.

O estopim dos embates entre Ramos e Caso foi o seguinte: Ramos publicou, em 1927, na revista Ulises, um artigo no qual afirmava que o mestre se estava repetindo, e que baseava sua popularidade mais na retórica e na performance durante suas conferências, do que no rigor de seus escritos filosóficos (BASAVE, p. 14). A Ramos ter travado tal combate foi tão significativo, para ele, que nas páginas de El perfil fez constar uma nota, em que mencionava tal texto (RAMOS, p. 136).

Importante frisar, então, que, se Ramos enfrentou a ira de discípulos de Caso, diversos outros nomes ligados à referida revista, onde publicou o dito artigo, se manifestaram a seu favor. Refiro-me à mecenas Antonieta Rivas Mercado, que custeava a publicação e, conforme Hernández Luna, teria lido e revisado a crítica de Ramos ao mestre ateneísta, antes que viesse a público (HERNÁNDEZ LUNA, 1982, p. 135). Refiro-me também a Jorge Cuesta, que, logo em seguida, publicou, em Revista de revistas, o artigo Antonio Caso y la crítica (Idem, p. 149).

Em sua avaliação, Cuesta retomou as teses de que Caso era melhor propagandista do que filósofo; e de que seu duvidoso talento como filósofo não fazia jus à vasta fama. Cuesta contou que por anos buscara compreender por qual motivo não lograva entusiasmar-se com os exercícios reflexivos do ateneísta, e que por isso se sentia, por vezes, solitário, senão estúpido. Concluiu, na ocasião, que com felicidade e identificação, pois, lera o texto de Ramos (Apud. 
HERNÁNDEZ LUNA, p. 150). Como retomaremos em outra seção deste Capítulo, por isso, entre outros motivos, Cuesta foi uma figura muito importante, na carreira de Ramos, como filósofo.

Lembremos, quanto a tal polêmica, ainda, que o próprio Caso reagiu, profundamente magoado, publicando um caderno de 30 páginas intitulado Ramos y yo: un ensayo de valoración personal; fazia, ali, irônica referência ao livro de Juan Ramón Jiménez, Platero y yo, que contava a história de um menino e seu burrinho (ARREOLA, p. 89).

Em 1928 Ramos lançaria seu primeiro livro, Hipótesis, no qual fez constar o dito artigo em que criticava Caso, com uma nota de pé de página, em que contestava a violenta reação do antigo professor. Demonstrando que já andava a considerar a concepção psicanalítica que associa sentimento de inferioridade e postura violenta, arrematou a questão: "En verdad yo no esperaba que Caso me declarara el más sabio de los hombres, pero sí que luchara con recursos limpios. El foul es un arma de los que se sienten vencidos" (Apud. BASAVE, p. 16).

Sobre sua própria vivência como discípulo de Caso, declarou, em um dos ensaios inéditos que compuseram Hipótesis, denominado Mi experiencia pragmatista:

Puedo decir que entonces me sumergí íntegramente en el romanticismo filosófico, como quien en un instante se entrega a una mujer de modo absoluto cuidando, sin embargo, de no prometer fidelidad eterna. (...) Así es como se descubren mejor los defectos de una filosofía: es preciso entrar a la nube rosada para saber que es húmeda y gris" (Apud. Idem, p. 110). ${ }^{10}$

Ramos criticava em Caso, afinal, algo que era comum a Vasconcelos: o fato de suas concepções filosóficas se darem sem qualquer sustentação empírica mais robusta. Semelhança que Ramos, a despeito dos desentendimentos com o primeiro e da amizade com o segundo, visualizava e registrou em passagem de El perfil, na qual afirmou que o Ateneo de la Juventud como um todo ignorou "la historia contemporánea", "la realidad circundante"; quer dizer: “fueron el alma de México, pero un alma... sin cuerpo" (RAMOS, p. 137).

\footnotetext{
10 "Pragmatista" tem um sentido muito específico, na reflexão de Ramos. Um sentido um tanto distinto do proposto pelos filósofos norte-americanos William James e Charles S. Peirce, que, no final do século XIX, se aproximaram do empirismo e fincaram as bases da Psicologia Comportamental, enfatizando o sentido prático, utilitário da Filosofia; a busca cientificista por respostas. Baseando-nos na explicação de Abelardo Villegas, podemos dizer que o pragmatismo, conforme Ramos, se aproximava de tais concepções na medida em que crítico da tendência, em México, de a Filosofia se centrar no abstrato, em doutrinas pré-determinadas, absolutas, fixas, fechadas; e na crítica à noção positivista de ciência, que concebia uma verdade que antecede a todo entendimento, e que está pronta, esperando para ser descoberta. Porém, o pragmatismo experimentado por Ramos na juventude, e que ele criticou na maioridade, começava a se afastar do cientificismo; seguindo a interpretação do filósofo francês Henri Bergson, se irmanava ao vitalismo, entre outras teorias ligadas ao instintivo, o intuitivo, espiritual, cósmico, exotérico (VILLEGAS, p. 110).
} 
O dominicano Pedro Henriquez Ureña, também ateneísta, sintetizou esse interesse pelo "não real", pelo não-pragmático, pelo não-utilitário, num ensaio publicado na Argentina, em 1925 - Utopia de América -, do qual destaco a seguinte elucidativa passagem:

\begin{abstract}
"Avancemos, en fin, hacia nuestra utopía. ¿Hacia la utopía? Sí, hay que ennoblecer nuevamente la idea clásica. La utopía no es vano juego de imaginaciones pueriles: es una de las magnas creaciones espirituales del Mediterráneo, nuestro gran mar antecesor. El pueblo griego da al mundo occidental la inquietud del perfeccionamiento constante. Cuando descubre que el hombre puede individualmente ser mejor de lo que es y socialmente vivir mejor de cómo vive no descansa para averiguar el secreto de toda mejora, de toda perfección. Juzga y compara, busca y experimenta sin descanso; no le arredra la necesidad" (UREÑA, s/d, p. 5-6).
\end{abstract}

Rovira nos lembra, a propósito, que nenhuma das conferências apresentadas pelos ateneístas em 1910 fez referência aos problemas sociais e políticos mexicanos, e tampouco aos grupos revolucionários que estavam em contenda: Caso falou sobre o escritor portoriquenho Eugenio María de Hostos, Vasconcelos obre o secretário de Educación Pública porfirista Gabino Barreda, e Ureña sobre o pensador uruguaio José Enrique Rodó (ROVIRA, p. 307).

Eu lembraria, pois, que é então nessa medida que o ser caritativo de Caso e a "raça cósmica" de Vasconcelos mais destoam do "pelado" de Ramos, que em certa medida seria passional, movido pelo coração, sim, mas que sabia ser violento e imprevisível; que se caracterizaria por qualidades e defeitos bastante problemáticos e constrangedores para um intérprete que desejasse pronto direcionar o olhar em direção ao futuro.

O rompimento de Ramos com Caso, e a maior proximidade com Vasconcelos, se deram basicamente, então, sobretudo por oposição/identificação política? Talvez sim, em alguma medida; mas eu diria que, nesse caso, seria menos interessante partir das perspectivas "ideológicas" do autor de El perfil - sobre as quais ele parece ter sempre optado por ser bastante discreto -, e mais de suas visões acerca da função social do filósofo e das relações entre intelectuais e poder instituído, no México.

Faz-se mister, logo, dedicar aqui alguns parágrafos a uma breve reflexão acerca mais algumas de possíveis diferenciações entre Caso e Vasconcelos.

Em El perfil Ramos apresentou a seguinte comparação: enquanto as reflexões de Caso se orientavam pelo "ensino universitário", as de Vasconcelos se orientavam pela "ação política"; enquanto Caso tratava de introduzir o sentido moral, espiritual, como disciplina, na universidade, Vasconcelos partia de "un concepto místico de la vida en que lo estético 
desempeña la función decisiva" para empreender uma série de reformas, através da Secretaría de Educación Pública (RAMOS, p. 135-136).

Em El laberinto de la soledad, o "bucanero" Paz, ${ }^{11}$ retomou essa comparação, em passagem bastante referida, embora, creio eu, um tanto distorcida e redutora. Na ocasião, Paz definiu que, enquanto o primeiro desses autores seria um "intelectualista", o segundo seria um "antiintelectualista", defensor da "intuição", da "emoção", do viver como promotores de um saber total (PAZ, p. 126-127).

Enrique Krauze e Rosa Kolteniuk repetem tal diferenciação entre Vasconcelos e Caso: em sua análise, as formulações do primeiro desses pensadores é rotulado "dramatismo pedagógico", e o trabalho desenvolvido pelo segundo, "impulso místico" (KRAUZE; KOLTENIUK, p. 32). Caso, cuja conduta, como intelectual, esses dois pesquisadores focaram em análise recente, teria pontuado, em conferência, de fins da década de 1920: "Sangre de indio y sangre española es la mía. Pero soy un mexicano de pasiones serenas. Mi amor por la patria no me inspiró la profesión de político ni de soldado. Mi ideal fue el estudio, los libros, el arte, la filosofía" (Idem, p. 20).

Ora, tais perspectivas nos confundem, porque, embora estilisticamente se forcem a uma semelhança com as proposições de Ramos, sugerem em Caso um intelectualismo que Ramos não viu. Para Ramos, como viemos acompanhando, tanto um quanto outro ateneísta haviam sido ou desejado ser utópicos, antiintelectuais e irracionalistas: Caso, revertendo o pensamento-intuição, o pensamento-instinto em debates acalorados na universidade; e Vasconcelos, investindo sua atuação como filósofo na transformação dos modos de pensar e ser da massa.

Note, isso posto, que Ramos considerava que, diferentemente de Caso, Vasconcelos ao menos em sua utopia havia sido o responsável por efetivamente abrir as portas do pensamento mexicano para a universalização; para um sentido de "mexicanidade" que ao menos no discurso incluía um sentido de ação, e que considerava uma tensão: entre o que se julga próprio, e o que se julga alheio. Daí propor:

la doctrina de Vasconcelos de la 'raza cósmica' no es una profecía creíble, pues resulta un ideal desmesurado en comparación con el estado actual de nuestra vida y sus posibilidades efectivas", mas nela vemos "expresarse mitológicamente la voluntad universalista de nuestra raza (RAMOS, p. 137). e isso representava, en última instancia, certa libertação revolucionária.

\footnotetext{
${ }^{11}$ Há uma passagem do sexto capítulo do primeiro Capítulo desta Tese que explica porque designo aqui Paz "bucanero".
} 
De qualquer forma, Ramos se revela, em El perfil, bastante mais preocupado com o verdadeiro mexicano e o México real. De acordo com o professor Victórico Muñoz, em seu clásico, "Ramos no separa las ideas de la realidad, la filosofía de la acción de filosofar, porque se trata de un filosofar en situación y esta situación no está separada del contexto o circunstancia que la influye" (MUÑOZ, p. 01). Sua Filosofia não é, assim, ao ver de Muñoz, uma ponderação tão somente sobre pensamentos, mas sobre épocas, situações, práticas, relações, ações, cotidianos, percorridos por ideias.

Esse quadro nos permite, pois, sustentar que com seu ensaio mais famoso Ramos tratou de que dar um passo para fora da geração ateneísta. Que El perfil surgiu, na década de 1930, como uma obra dissonante; e, para a década de 1940, como uma obra-ponte.

Decerto ao menos no discurso muitos intelectuais mexicanos de meados do século XX começaram a propor reflexões que se propunham diversas das proposições ateneístas, e que, num mesmo sentido, se aproximavam das reflexões de Ramos. Muitos intelectuais reagiram à tendência utópica até então predominante, e demonstraram preocupação por confrontar suas proposições com fontes ou dados da realidade presente. Como eco ou compondo um movimento notável também nos discursos do governo callista e do Maximato, eles defenderam a necessidade de se trabalhar com versões do mexicano mais condizentes com o real, e de se pensar em possibilidades de uma efetiva participação dele no mundo, tal como se encontrava, concretamente, organizado.

Com efeito, Rafael Segovia aponta que Luis L. León, um dos nomes mais expressivos do Maximato, secretario do Partido Nacional Revolucionário, pontuou em 1934, mesmo ano em que Ramos publicaría El perfil:

Los gobiernos de casi todos los países sostienen universidades propias en las que se impone siempre la tendencia filosófica, social o jurídica que priva en el Gobierno; y en cambio hasta la fecha, en México hemos visto con tristeza que los conocimientos superiores que se imparten en la Universidad Nacional distan mucho, ya sea por el cuerpo docente de ella, ya sea por la falta de orientación de la misma o por otras causas, de conseguir este objetivo (Apud. SEGOVIA, p. 355).

Conforme Paz, apenas no final dos anos 1940 interpretações ensaísticas frequentemente irracionalistas" - foram sendo abandonadas, e começaram a ser elaboradas, para a abordagem do Humano, investigações históricas, filosóficas, sociológicas, psicológicas com instrumentais específicos - ao ver de Paz, “mais consistentes” (PAZ, p. 85).

Conforme Krauze e Kolteniuk, intelectuais dessa nova geração, inclusive, “en su afán por identificar el progreso proprio con el de la nación, terminaran por recordar a los 
científicos del Porfiriato"; foram "todos pragmáticos, sistemáticos, progresistas, triunfalistas, keynesianos, industrialistas" (KRAUZE \& KOLTENIUK, p. 31).

Eu apontaria, para verificação, alguns intelectuais que à época ganharam destaque: os já citados Moisés Sáenz, Narciso Bassols, Vicente Lombardo Toledano e Manuel Gamio.

Após a perda do cargo por Vasconcelos, e ao longo de toda a década de 1920 - quer dizer, nesse intervalo que há de ter sido tão significativo, intelectualmente, para Ramos nenhum dos homens que estiveram à frente da Secretaría de Educación Pública se destacou. $\mathrm{Na}$ verdade, apenas um subsecretário formulou e encaminhados projetos que ganharam visibilidade: Moisés Sáenz.

Conforme o professor norte-americano John A. Briton, Saénz, ao longo de todos os anos trabalhando no dito órgão, sofreu forte oposição. Vasconcelos e seus partidários, dentre os quais talvez Ramos, o chamavam "pocho" - designação pejorativa para o mexicano que cede aos interesses imperialistas dos Estados Unidos. De fato, havia ele estudado nos Estados Unidos, e de lá retonara, inspirado por ideias do pedagogo John Dewey e do antropólogo Franz Boas (BRITON, p. 78).

Para além das críticas recebidas, diz Francisco Javier Guerrero, Saénz não foi um intelectual meramente interessado em aplicar fórmulas estrangeiras. Conforme esse pesquisador, ele teria buscado entender o homem mexicano em sua composição étnica, variedade cultural, necessidades e potencialidades. Sobretudo, se dedicou à análise das condição das comunidades indígenas, e às possibilidade de integração delas ao México moderno (GUERRERO, p. 52).

Conforme o historiador francês Philippe Schaffhauser, em La escuela rural mexicana (1928), Sáenz defendeu, então, a ideia de uma escola rural, elaborada a partir dos conhecimentos e elementos das próprias comunidades, e não que funcionassem como elemento estrangeiro, encarregado de transformá-las a partir de padrões externos (MIZZI, p. $15)$.

Devemos nos lembrar, ainda, que foi sob a iniciativa de Sáenz e seu subsecretário Bernardo Gastellúm que a Universidad Nacional Mexicana ganhou autonomia. Sem dúvida, como explica Tzvi Medin, esse foi um nó de negociação importante, no jogo político que configurou o Maximato; uma moeda de troca com os intelectuais que tendiam a uma postura avessa ao regime. Todavia, correspondeu também, decerto, a peça fundamental, do quadro pedagógico mais amplo, concebido pelo secretário, para a educação no México moderno (MEDÍN, p. 160). 
Em 1931, no governo de Pascual Ortiz Rubio, mas ainda sob a determinante influência de Calles, foi indicado como secretário outro nome que alcançaria projeção: Narciso Bassols. Como aludi, en passant, há pouco, Bassols seguiu no cargo quando um outro presidente, Abelardo Rodriguez, assumiu o posto, também sob a anuência do Jefe Maximo; foi nessa época que Samuel Ramos trabalhou para a Secretaría.

Antes de chegar a tão importante cargo, Bassols era já reconhecido, no universo intelectual mexicano, por seus vastos conhecimento acerca das proposições de Karl Marx. Na Secretaría de Educación Pública, assumiu uma postura bastante distinta do espiritualismo de tom católico de Caso, aderiu à campanha antirreligiosa de Calles, defendeu o ensino laico, e promoveu a importância de uma "educação popular", que ele passou a rotular "socialista".

Também aluno de Caso, Lombardo Toledano rompeu com a linha espiritualista do mestre, por considerá-la alienante, e, tal como Bassols, passou a adotar o materialismo histórico como referência teórica ainda na década de 1920. Foi diretor da Escuela de Bellas Artes, antes sob a autoridade do pintor Diego Rivera; da Escuela Nacional Preparatória, e também da Universidad Nacional Obrera, conferindo a todas essas instituições, o quanto pôde, direcionamentos socialistas. Em 1933, como vimos, fomentou por isso um largo debate entre cátedras, revistas e jornais da Cidade do México, sobre a possibilidade de se oficializar um direcionamento marxista para a formação universitária mexicana.

Sabe-se que o projeto de Toledano não vingou. Porém, anos mais tarde, Bassols logrou que o ensino estatal, como um todo, no México, foi oficialmente rotulado, na constituição, "socialista".

Deve-se considerar, portanto, que tais intelectuais se definiram, e muito, por seus posicionamentos políticos. Não estou aqui querendo propor que atuaram subservientes a Calles ou à lógica do Maximato; e sim que, como funcionários do governo devem ser considerados como pensadores voltados para a ação - para aspectos concretos, de seu país, que pretendiam alterar, e para possibilidades concretas de alterar esses aspectos.

Ao ver de Tzvi Medin, os pensadores que vão ganhando maior projeção, ao findar do Maximato, são justamente os politicamente mais engajados; em movimento que acompanha o fortalecimento dos grupos cujos discursos foram mais radicais; num movimento que, conforme o dito pesquisador, culminaria na chegada de Lázaro Cárdenas à presidência (MEDÍN, p. 182).

Quanto a Gamio, trabalhou no Museo Nacional, como pesquisador e professor, e ali chegou a diretor da Dirección de Antropologia. Cuando Calles chegou à presidência, em 
1924, lhe ofereceu, como a Sáenz um cargo, um de subsecretário de Educación Pública. Gamio relutou em aceitá-lo, e, aceitando-o ali permaneceu por pouco tempo.

Conforme Ángeles Gonzalo, “A los pocos meses de desempeñar el cargo descubrió una serie de corruptelas y las informó al Presidente. Ante la indiferencia del mandatario, las denunció públicamente, lo que motivó que Calles, indignado, lo cesara. El arqueólogo respondió en los periódicos manifestando su satisfacción" (GONZALO, p. 212). Acabou se exilando.

A pesquisadora brasileira Steffanny Soares de Menezes Dias, mestranda pela Universidade de Goiás, estudiosa de Ramos e de Gamio, ignora qualquer registro de contato ou convivência, entre os escritores de El perfil e de Forjando pátria. ${ }^{12}$ Porém, o interesse pelas especificidades do México real, moderno, e o desacordo com as políticas e os políticos, de Calles, pode ser que tenham promovido certa identificação entre eles. Ademais, o ilustre sociólogo Roger Bartra, em seu La jaula de la melancolia, inclui Gamio e Ramos numa mesma geração de intelectuais mexicanos. O que me leva a considerar se afinal, a leitura de seus textos mais famosos confirma ou não terem eles compartilhado propósitos de análise e visões acerca do homem mexicano.

Senão, vejamos: Gamio foi aluno do antropólogo Franz Boas, na Columbia University, na década de 1910. E, creio, como arqueólogo, como um estudioso de registros históricos materiais, de civilizações pré-colombianas, no México, propôs entendimentos acerca da história um tanto distinto de Ramos, ensaísta e filósofo. Esse entendimento perpassa todo o texto de Forjando pátria, e lá é definido da seguinte maneira: "la Historia es, en general, el conjunto de informaciones relativas a la naturaleza, origen, carácter, evolución y tendencias de las civilizaciones del pasado”. (...) Aquellas experiencias constituyen por sí mismas a la historia, pero permanecen mudas, invisibles, si no atinamos a distinguirlas, clasificarlas y exponerlas (GAMIO, p. 109-110).

Ramos, de maneira distinta, em El perfil, destacou não o trabalho de reconstrução, do historiador, mas de revisão das versões acerca do devir histórico de um povo. Ele escreveu, em seu ensaio, que "si concebirmos la historia como debe concebirse, no se nos aparecerá como la conservación de um pasado muerto, sino como um proceso vivente en que el pasado se transforma en um presente siempre nuevo" (RAMOS, p. 101).

${ }^{12}$ Cf. DIAS, Stefanny S. de M. O Intelectual e seu Tempo: Samuel Ramos e Manuel Gamio na formação da cultura mexicana pós-1910. In: Anais do X Encontro Internacional da ANPHLAC. São Paulo, julho de 2012. DIAS, Stefanny S. de M. Manuel Gamio e Samuel Ramos: perspectivas acerca do indígena na construção da identidade nacional mexicana pós-Revolução de 1910. In: Anais do XXVI Simpósio Nacional de História da ANPUH. São Paulo, julho de 2011. 
A partir de tais ponderações, sugiro a hipótese de que, se Gamio desejou coletar dados acerca dos modos de vida, no México, para a partir deles "forjar" um referencial de mexicano, genérico; Ramos compreendeu que tais formulações eram e seriam sempre fluidas, e variáveis, conforme as necessidades de cada tempo.

Por isso, Gamio se sentiu à vontade para sugerir: "toca hoy a los revolucionários de México empuñar el mazo y ceñir el mandil del forjador para hacer que surja del yunque milagroso la nueva patria hecha de hierro y bronce confundidos" (GAMIO, p. 06). Por isso, por seu distinto posicionamento, como destaquei anteriormente, Ramos confessou, desde as primeiras páginas de seu livro, o receio de definir pontualmente se existia ou não, afinal, uma cultura, uma maneira de ser, exclusivamente, concretamente e invariavelmente "mexicana" (RAMOS, p. 96).

Dentre os intelectuais mexicanos por mim agora aludidos, Gamio, de fato, se diferencia. Seu Forjando pátria, afinal, foi lançado bons anos antes de El perfil, num mesmo momento em que Caso e Vasconcelos estavam lançando seus ensaios. Seu Forjando pátria, afinal, partiu de perspectivas alheias aos acirrados e renovados problemas do México dos anos 1930.

Quanto aos outros três ensaístas mexicanos acima mencionados: Sáenz foi também aluno do Boas, mas sobretudo do pedagogo John Dewey, na mesma Columbia University; já Bassols e Lombardo Toledano, vimos, se rotularam "marxistas". Procederam, afinal, tal como Ramos - que foi leitor de Adler e Jung -, um diálogo com teorias estrangeiras, buscam referenciais sólidos, através do quais pudessem estabelecer um olhar novo, e mais preciso sobre a situação do homem e do México, do período.

Há, porém, a respeito dos escritos de Sáenz, Bassols e Lombardo Toledano, uma questão fundamental, que os afasta da abordagem proposta nesta Tese: as reflexões sobre o México moderno que produziram não circularam como ensaio, entres as décadas de 1900 e 1930; seus textos que naquela época causaram maior repercussão foram anotações para conferências e declarações oficiais, documentos e relatório burocráticos; nada muito articulado e arrematado num tom generalizante, ensaístico.

Sim, de todos esses expressivos autores, portanto, aparentemente apenas Ramos logrou publicar um ensaio completo que, partindo do diálogo com metodologias estrangeiras, já nos anos 1930 ousava sugerir um novo modo de se pensar as questões nacionais; um modo já um tanto afastado daqueles trabalhados pelos ateneístas; um modo que dialogava bem explicitamente com teorias e metodologias estrangeiras; um modo que se voltava ao México 
concreto e presente. Poderíamos, pois, considerar El perfil como uma espécie de "elo perdido"; se não considerássemos o que vinham penando, à época, os literatos mexicanos.

A eles, pois, dedicarei uma das próximas seções deste Capítulo. 


\subsection{Retomando e comparando o lugar de Holanda e Ramos no ensaísmo brasileiro e mexicano das primeiras décadas do século $\mathrm{XX}$}

Como viemos acompanhando nas duas outras seções deste Capítulo, a despeito das diferenças, a produção ensaística brasileira e mexicana de princípios dos novecentos, na qual se inserem Raízes e El perfil, guarda algumas semelhanças importantes.

A clara dissociação entre os mais notáveis escritores, que se dedicaram à forma do ensaio para abordar o homem do Brasil moderno, contrasta com a existência do célebre Ateneo de la Juventud, que concentrou a produção dos ensaios de maior repercussão, no México. Porém, como vimos, entre os ateneístas também houve considerável variação de perspectivas, ideias e percepções acerca da função social das reflexões acadêmicas, e dos livros, dos ensaios.

Como clara semelhança entre os textos propostos entre as décadas de 1900 e 1930, no Brasil e no México, em forma de ensaio, eu destacaria, antes de mais, o seguinte movimento: a princípio, era corrente, em ambas nações, a iniciativa de romper com a concepção de verdade positivista, como uma verdade dada, fechada, anterior à análise, e a ser descoberta; depois, aqui e lá, passou ganhou notoriedade a preocupação com lidar com a realidade do momento, e em compor análises precisas acerca dela.

No primeiro momento, o ensaísmo de Bomfim, por exemplo, se aproximou da lógica do ensaísmo dos ateneístas mexicanos, pelo interesse apaixonado pela noção de "utopia". O autor sergipano, no ensaio de 1905, lembrando Ureña, escreveu: "Sejamos utopistas, contanto que trabalhemos. Sem os utopistas de outrora os homens viveriam, ainda hoje, nas cavernas, miseráveis e nus. Dos sonhos generosos saem realidades benfazejas. A utopia é o princípio de todos os progressos e o esboço de um futuro melhor” (BOMFIM, p. 382).

Para reforçar a proximidade dos argumentos, e para deleite do leitor, transcrevo mais uma vez a passagem de Utopia de América, de Ureña:

\footnotetext{
“Avancemos, en fin, hacia nuestra utopía. ¿Hacia la utopía? Sí, hay que ennoblecer nuevamente la idea clásica. La utopía no es vano juego de imaginaciones pueriles: es una de las magnas creaciones espirituales del Mediterráneo, nuestro gran mar antecesor. El pueblo griego da al mundo occidental la inquietud del perfeccionamiento constante. Cuando descubre que el hombre puede individualmente ser mejor de lo que es y socialmente vivir mejor de cómo vive no descansa para averiguar el secreto de toda mejora, de toda perfección. Juzga y compara, busca y experimenta sin descanso; no le arredra la necesidad" (UREÑA, s/d, p. 5-6).
} 
Pode-se supor, a partir disso, que esses autores, por lidarem com uma retórica mais solta e inventiva, foram mais tendenciosos em suas formulações. Contudo, também no segundo momento acima referido os principais ensaístas brasileiros e mexicanos se revelaram intimamente apegados a certas concepções político-ideológicas. Caio Prado, Toledano e Bassols, menos ou mais comprometidos com o governo de seus países, foram marxistas/socialistas; Holanda e Ramos, foram intelectuais preocupados em reavaliar os mais diversos tipos de discurso políticos, e críticos às distorções nas práticas políticas, no Brasil e no México.

No Brasil, como vimos, Candido falou em uma considerável ideologização, no ensaísmo da década de 1930. Já no México, quem assim classificou os anos trintas - apontei há pouco - foi o historiador Tzvi Medin (1982).

Talvez fique a impressão de que essa maior "ideologização" seria contraditória ante a maior preocupação com o estudo do Brasil e o México reais. Mas, para Piva, sobre o caso brasileiro, não: “os intelectuais do período vinham de famílias oligárquicas decadentes e eram confrontados pela leva de novos diplomados vindos das universidades livres e temiam perda de status. Por isso além de envolver-se com os debates políticos em voga, teriam saído do estilo ‘culto' e se profissionalizado" (PIVA, 2000, p. 82).

Foi uma tendência de certa forma observável, também, em território mexicano. A questão é que, entre os intelectuais mexicanos que citei como expressivos por volta de 1930, além de Ramos apenas Sáenz se profissionalizou. Sáenz, conforme descrito na seção anterior deste Capítulo, fez seus estudos superiores nos Estados Unidos, especializando-se em Pedagogia; e atuou sempre na área de educação indígena, mesmo após desentender-se com Bassols, e auto-exilar-se na América do Sul, no Peru.

É verdade que Lombardo Toledano, embora tenha se formado em Direito - quer dizer, num dos cursos-chaves nos quais todo jovem interessado pelas letras, no Brasil, ingressavam - fez-se Doutor em Filosofia pela UNAM, em 1933. Esse foi, por acaso, um trajeto semelhante ao de Ramos - que no entanto cursou Medicina, e não chegou a se formar; e também de Holanda - que no entanto, no Brasil, fez-se Doutor em História.

Porém, sobretudo deve-se ter em mente que Lombardo Toledano, ao longo de sua trajetória como intelectual, não chegou a ser, tal como Ramos, tal como Holanda, um especialista - dedicado tão somente a escrever e ministrar aulas em universidades. Ele foi um político profissional, investindo seu capital intelectual nas mais diversas instituições sindicais, educativas, e partidárias. 
Quanto a Bassols, cumpriu uma trajetória parecida com a de Lombardo Toledano. Entretanto, mais íntimos dos poderes instituídos, ditos "revolucionários", do que Lombardo, não seguiu por toda a vida atuando em cargos públicos, político-administrativos; após a derrocada política de Calles, acabou por abandonar a política e se dedicar tão somente à advocacia.

Um segundo ponto importante, a observar, entre o ensaísmo do Brasil e do México, das primeiras décadas do século XX, são as possíveis semelhanças entre a forma de nossos ensaístas observarem a modernidade brasileira e mexicana. Nos dois casos, como acompanhamos, houve a tendência de se considerar Brasil e México, respectivamente, como especificidades civilizacionais, e os brasileiros e os mexicanos como seres únicos, em seus problemas e qualidades; portanto, não necessariamente inferiores, como vinham pregando, nos dois países, as teorias raciais.

Aqui e lá, então, os ensaístas propuseram alternativas mais ou menos psicologizantes; e quase sempre num tom antropológico, quer dizer, considerando os modos de ser e os valores compartilhados, diariamente, habitualmente, historicamente. Nesse sentido, mais uma vez podemos recorrer, como exemplo, a Bomfim, que tal como Caso propôs ser "incontestável que o homem herda dos seus progenitores os caracteres psicológicos da classe, da ordem e da espécie"; mas que isso se daria não de maneira genética, constitutiva, e sim através das experiências, da educação (BOMFIM, p. 173).

No que tange aos autores cujas reflexões despontaram na década de 1930, devemos considerar um interesse comum, por sublinhar teóricos estrangeiros que teriam acessado para estruturar seus argumentos.

É claro que antes deles Bomfim, Paulo Prado e os ateneístas liam autores europeus e norte-americanos, e dialogavam com eles. Mas, preocupados em compor olhares novos, e bem tipicamente locais, dissolveram suas referências.

Caio Prado, Freyre, Holanda, Ramos, Sáenz, Toledano, Bassols, diferentemente, demarcaram, de forma mais ou menos clara, as principais referências conceituais, sobre a metodologia de suas análises acerca do que entendiam como tipicamente brasileiro, e tipicamente mexicano, no início do século XX.

Assim, se seguirmos a trilha de Dante Moreira Leite, Holanda pode ser considerado um "ponto intermediário entre o período ideológico e a fase de análise sociológica - ou realista - da vida brasileira" (LEITE, 2007, p. 386); e também Ramos, no México.

Esse último, embora tenha rotulado seu ensaio de "psicologia social", conferiu nele importância às práticas cotidianas, e efetivamente observou, descreveu e criticou detalhes dos 
modos de pensar e se portar dos mexicanos, dantes um tanto desprezados pelos utópicos ateneístas. E, embora fosse ex-aluno dos ateneístas e tenha pretendido um modo de pensar tipicamente mexicano, remeteu a complexos metodológicos academicamente aceitos, nos grandes centros políticos do Ocidente.

Para finalizar esta seção, convém retomar e desdobrar uma ideia apresentada momentos antes desta Tese, quando comecei a abordar as críticas mais comuns, atribuídas a El perfil. Naquele momento apontei que, anos depois da primeira publicação desse livro, na década de 1950, o próprio Ramos considerou o conceito de "pelado" como um conceito pouco interessante para se pensar, ainda, seus conterrâneos; mas que ele seguiu acreditando na importância de, como mexicano, se pensar sobre as especificidades do México moderno, assim como sobre modos modernos de se pensar o México - de se trabalhar por uma Filosofia Mexicana.

Sob esse aspecto, propus, Ramos se distinguia um tanto de Holanda, que tornou-se não apenas crítico do conceito de "homem" cordial, como de toda a estrutura reflexiva de Raízes: o projeto de reflexão, sobre o Brasil como um todo, generalizando, e buscando fundamentos de nosso modo de ser e pensar.

Hora de dizer que a essa diferença se associa outra, relativa à fortuna crítica de $E l$ perfil e Raízes. É que o dito ensaio mexicano tende hoje a ser considerado um livro de Filosofia; enquanto o ensaio brasileiro tem sido, entre nós, incluído entre grandes obras do "Pensamento político brasileiro".

A respeito desse conjunto de obras as mais diversas, chamadas no Brasil "pensamento político brasileiro", Gildo Marçal Brandão escreveu:

os seus contornos nunca foram muito claros"; "se trata de uma área de fronteira, acolhendo orientações intelectuais provindas das diversas ciências humanas, (...) no cruzamento de disciplinas tão variadas como a antropologia política e a sociologia da arte; a história da literatura e a história da ciência; a história das mentalidades e a sociologia dos intelectuais; a filosofia e teoria política e social; e a história das ideias e das visões-de-mundo (BRANDÃO, p. 232).

Para esse crítico, dantes considerada "mera pré-história ideológica a ser abandonada tão logo se tenha acesso à institucionalização acadêmica da disciplina científica", o "Pensamento político brasileiro" corresponderia a um "índice da existência de um corpo de problemas e soluções intelectuais, de um estoque teórico e metodológico aos quais os autores são obrigados a se referir no enfrentamento das novas questões postas pelo desenvolvimento social, como um afiado instrumento de regulação de nosso mercado interno das ideias em suas trocas com o mercado mundial" (BRANDÃO, p. 233). 
Ora, me parece que, como El perfil vem sendo considerado um dos primeiros estudos de Filosofia Mexicana, vem sendo observado como um estudo demasiadamente vago e impreciso de Filosofia Mexicana. Seu lugar como intersecção entre o ensaísmo ateneísta e um pensamento acadêmico mais formal é decomposto, e, afinal, sua importância histórica é borrada.

Se, porém, distintamente, nos concentrarmos nos avanços teórico-metodológicos que tal livro de Ramos, especificamente, representou, em meados de 1930, e se, junto ao professor Luis Patiño Palafox (PATIÑO, 2010), nos concentrarmos nas questões políticas - do homem mexicano ante a modernidade - que Ramos ali considerou criticamente, uma outra dimensão se abre.

El perfil, tal como Raízes na visão de Brandão, poderia ser compreendido, pois, como um estudo passado, datado, mas fundamental, na medida em que oferece parâmetros interessantes aos quais autores de outras gerações se refiram "no enfrentamento das novas questões postas pelo desenvolvimento social, como um afiado instrumento de regulação de nosso mercado interno das ideias em suas trocas com o mercado mundial" (BRANDÃO, p. 233). 


\subsection{O papel fundamental da vanguarda brasileira}

Everton Vieira Vargas, em seu estudo comparado sobre a intelectualidade brasileira e mexicana, lembra uma tese bastante comum, sobre a América Latina. Ele afirma que "a Literatura se converteu em veículo privilegiado para a construção de nossas nacionalidades" (VARGAS, p. 321).

Nesta seção, entretanto, tomo como referência outra tese de grande importância: conforme o historiador norte-americano Richard Morse, em seu clássico $O$ espelho de próspero (1982), a produção de "poetas, romancistas e artistas" latinoamericanos vinha equivalendo, através dos séculos, a um “veio capaz de afirmar a 'realidade' ibero-americana entre os dentes das Cassandras científicas"; um veio capaz de "expressar [nosso] mundo como centro e não como periferia" (MORSE, p. 137).

Neste Capítulo considero, logo, que a Literatura produzida no Brasil e no México de princípios dos novecentos não apenas se fez importante na medida em que forneceu alguns referenciais de identificação e acomodação para brasileiros e mexicanos. Fez-se importante também (e talvez sobretudo) por apresentar críticas a determinados padrões de brasilidade e mexicanidade como "essências" ou "naturezas"; por problematizar visões correstes entre e fora de nosso subcontinente, acerca de nossos cidadãos e instituições, assim como por focar desdobramentos na contemporaneidade, no presente.

Nesse sentido, podemos considerar que ensaístas e literatos, naquela conjuntura, no Brasil e no México, trabalharam conjuntamente não apenas criando utopias de acomodação das diversidades, e alienação dos conflitos, convenientes aos governos instituídos. Eles exploraram maneiras de percebermo-nos própria; a qual, na década em que foram escritos Raízes e El perfil, creio, remetia tanto à percepção da análise sociológica e histórica, como a um procedimento pessoal, crítico e subjetivo.

Dessa seção em diante, então, abordo relações entre o ensaísmo brasileiro e mexicano e as vanguardas literárias atuantes em cada uma dessas nações. E considero propósitos, elaborações, visões sobre a função social dos intelectuais, e articulações entre escritores e Estados.

Em se tratando do Brasil, eu começaria lembrando que o sociólogo e ensaísta Gilberto Freyre escreveu Literatura, incentivado pelo amigo José Lins do Rego: compôs poesias, reunidas em obra apenas em 1962, em Talvez poesia; e textos em prosa que chamaria “seminovelas": Dona Sinhá e o filho padre (1964) e O outro amor de Dr. Paulo (1977). Ele 
também recorreu a obras literárias como fontes para compreensão dos modos de ser e pensar do homem brasileiro em Casa-grande \& senzala e Sobrados \& mucambos.

Ademais, pode ser identificado a literatos da região Nordeste, com os quais conviveu no chamado Centro Regionalista, fundado em 1924. Em 1926, escreveu o Manifesto Regionalista; que destacou o interesse do Centro pelos "problemas do Nordeste", e o projeto de "reabilitar valores e tradições do Nordeste", nos mais diversos campos de produção intelectual (FREURE, 1996, p. 48).

Nesse manifesto, Freyre se dizia associado, em suas intenções, a "homens práticos" e "poetas". Ele se referia, por um lado, a "homens públicos ou de ciência", e "velhos lavradores ou homens de campo voltados inteligentemente para os problemas de defesa e valorização da paisagem ou da vida nos seus aspectos rurais ou folclóricos". E, por outro lado, - que nesta seção mais interessa - com "homens de letras empenhados na defesa dos nossos valores históricos", "homens de saber interessados em dar sentido regional ao ensino, à organização universitária e à cultura intelectual" (Ibidem).

Freyre ali decerto não compôs um panorama estético, com itens a serem consultados pelos literatos. Mas ao propor o "local" como um vértice de identificação entre todos os frequentadores do Centro, definiu dados sociológicos ("valores históricos", "sentido regional") como referencial poético a ser ou quer vinha sendo por eles trabalhado.

Entretanto, o Manifesto não se restringia a pensar o passado e artigos de coleção, folclóricos. Nele se enfatizava, como vimos, como tema o Nordeste moderno, em suas experiências contemporâneas, problemáticas.

Outro tex to crítico considerado como expressivo da renovação da Literatura nordestina do período foi o romance A Bagaceira (1928), do paraibano José Américo de Almeida. Costuma-se dizer, a respeito dele, que se caracterizou por "excesso de análise sociológica" e o apagamento da voz subjetiva do narrador.

Crítico, Luiz Costa Lima pontuou, pois, que "a falha central de Almeida é a sua incapacidade de ultrapassar o realismo mais primário" (LIMA, p. 337); e Afrânio Coutinho, que autores ligados a Almeida se restringiriam a intenções regionalistas mesquinhas; esforçando-se por endossar clichês vazios de uma identidade nordestina e também valorizar aspectos claramente negativos da região (COUTINHO, p. 204).

Porém, fato é que em outros textos Almeida pontuou a dimensão subjetiva de sua escrita, como na espécie de prefácio-manifesto de A bagaceira, intitulado Antes que me falem. Em estilo que lembrava os manifestos da vanguarda paulista da época, pontual e nada articulado, ele ali afirmou que: "há muitas formas de dizer a verdade", que "o naturalismo é 
uma bisbilhotice de tropeiros", que "ver bem não é ver tudo: é ver o que os outros não veem", que "escrever é disciplinar e construir", que "valem as reticências e as intenções"; quer dizer: que, conforme seu entendimento, tão importante quanto tomar como tema a realidade à volta eram a dúvida e os anseios dos autores, ao comporem seus quadros sobre essa realidade (ALMEIDA, p. 3-4).

Elaine Aparecida Lima vem analisando, pois, em que medida a Literatura nordestina desse momento ultrapassava o rótulo de "documental", e afirmando:

Neste contexto, opomo-nos à corrente crítica que afirma a década de 1930 como momento em que a literatura é vista como fraude, engodo, retórica, enquanto a sociologia representa a revelação e a ação; opomo-nos ao entendimento de que [os autores de então, no Nordeste] aproximando-se do positivismo (...) interditam a subjetividade (LIMA, p. 216).

O mesmo não parece ter ocorrido, então, com outros autores identificados ao Manifesto Regionalista, além de Almeida: a exemplo do romancista paraibano José Lins do Rego e do poeta alagoano Jorge Lima.

Segundo Robson dos Santos, esses dois escritores seriam, dentre os literatos entusiasmados com os projetos do futuro autor de Casa-grande \& senzala e Sobrados \& mисатbos, aqueles que produziram os frutos mais interessantes da literatura do Nordeste, em finais da década de 1920 e inícios da década de 1930. E o teriam feito articulando interesse pelo social e subjetivismo (SANTOS, 2011).

Quanto a Rego, abordou as alterações sociais vivenciadas pelos homens, famílias e grupos tradicionalmente envolvidos no processo de produção do açúcar nordestino, mas em tom bem pessoal, memorialístico, na trilogia Menino de engenho (1932), Doidinho (1933) e Banguê (1934). Quanto a Jorge Lima, tratou da mecanização usineira nordestina em composições marcadas por considerável melancolia e saudosismo, reunidas em $O$ menino do mundo impossível (1925), e compilações (de 1927, 1929, etc).

Creio que o alagoano Graciliano Ramos também foi, à época, um autor muito importante, por conceder foco ao Nordeste real, considerando a dimensão humana, e conferindo importância de seu papel criador, como autor. Escreveu Caetés (1933), de enredo convencional mas emblemático título; e São Bernardo (1934), sobre um homem do campo que ascendeu socialmente, pragmático e ignorante, e suas contradições de perspectiva ante personagens que representam diversos estratos sociais - sua mulher intelectualizada, homens da elite tradicional, xucros empregados. Também escreveu Vidas secas (1938), sobre a realidade do povo miserável do sertão brasileiro; e Angústia (1936), monólogo de um funcionário público desinteressado da vida, e aborrecido ante tudo. Esse último, escrito 
enquanto Graciliano Ramos encontrava-se preso, por inimigo político de Getulio Vargas, não apresenta sequer uma referência explícita ao presidente/ditador, mas certamente transparece o estado de espírito do autor no momento.

No que diz respeito a Freyre, é comum se dizer que mesmo a forma de Casa-grande \& senzala e Sobrados \& mucambos são remetem tão somente a teóricos da sociologia e antropologia como ao estilo de Marcel Proust, em Em busca do tempo perdido. Para muitos de seus intérpretes, a maneira como Freyre passeava, em suas análises, entre o presente e o passado brasileiros lembrava bastante o estilo do romancista francês. Em seus ensaios, portanto, teria trabalhado por uma versão do real que explicitaria a participação do autor na concepção desse real (SANTOS, 2011, p. 41).

Ora, se os escritores ditos "regionalistas", nordestinos, se dispuseram a considerar a realidade rural local, os conflitos e tensões específicos do campo, no Nordeste, trabalharam em seus livros algo da literatura francesa oitocentista, mas também do realismo brasileiro.

A intenção de abordar o real adentrou, pois, nossa Literatura de princípios dos novecentos, e resultou em textos memoráveis sobre a vida nas cidades, ou, mais especificamente, na capital - de João do Rio, autor de A alma encantadora das ruas (1908), a Lima Barreto, autor de Triste fim de Policarpo Quaresma (1915). Sobre o homem do campo, merece destaque Os sertões (1902), um texto jornalístico, memorialístico do também carioca Euclides da Cunha; e Urupês (1918), Cidades mortas (1919) e Ideias de Jeca Tatu (1919), do paulista Monteiro Lobato.

Em São Paulo, a preocupação com a abordagem da realidade urbana moderna, presente, contemporânea, na Literatura, ganhou ênfase na década de 1920. Como já foi de certa maneira antecipado neste Capítulo, seções antes, Paulo Prado e Holanda fizeram parte de um movimento literário paulista denominado modernismo. Hora de dizer que foi esse movimento, afinal, que buscou cumprir a aludida demanda.

Paulo Prado e Holanda, como Freyre, portanto, são outros bons exemplos de conexões entre o ensaísmo brasileiro das décadas de 1920 e 1930 e a Literatura.

Especificamente a respeito de Holanda, pode-se dizer que investiu esforços no campo literário, quando jovem, estampando contos de notável estilo vanguardista, em revistas e jornais; e também artigos de crítica, sobre iniciativas e livros publicados pelos modernistas de São Paulo, entre outros temas.

Foi próximo, amigo e respeitado por aqueles que viriam a ser repetidamente mencionados como os grandes poetas de nossa vanguarda. Mario de Andrade, por exemplo, não quis deixar de manter Holanda por perto, mesmo quando ele se mudou de São Paulo para 
o Rio de Janeiro; e tratou de convocá-lo a prestar assessoria à revista Klaxon, na busca por assinantes, na então capital do país. Conforme Conrado Pires de Castro, Tristão de Ataíde, em artigo publicado em 1929 na revista Estudos, rotulou Holanda "fiel sentinela do modernismo", a quem caberia reivindicar o "bastão de orientação do verdadeiro modernismo" - pela iniciativa de editar a revista Estética (Apud. CASTRO, 2009, p. 196).

Como nos lembra Arnoni Prado, em meados da década de 1920, porém, mais precisamente no ano de 1926, Holanda rompeu com o projeto modernista como um todo, e dirigiu-se ao interior do estado do Espírito Santo, onde passou a atuar como jornalista político. De volta ao Rio de Janeiro, seguiu trabalhando em agências de informação, até surgir a oportunidade, já comentada, de atuar como correspondente na Alemanha. Voltou da viagem com o esboço de Raízes na bagagem; tal esboço parecia ser a consolidação do desencanto com a atividade literária, e o passaporte de entrada no universo acadêmico, como historiador (PRADO, 2006, p. 302).

Contudo, alguns anos depois, fato é que Holanda voltaria a contribuir assiduamente para a imprensa especializada em Crítica Literária. E é verdade que o gosto pela crítica também se fez, de alguma maneira, presente em seu ensaio sociológico de estreia.

Para começar, consideremos um ponto mais facilmente notável e, portanto, considerável: a tomada, em Raízes, tanto da literatura portuguesa quinhentista, quanto do romantismo brasileiro, como fontes importantes para se conhecer o brasileiro moderno - a cordialidade, antecedentes e desdobramentos.

Senão, vejamos: consta, em Raízes, que se poetas portugueses do século XVI, tais como Luis Vaz de Camões, trabalhavam pela exaltação da empresa da colonização da América, entre a gente comum, em Portugal, naquele momento, seria corrente uma considerável desconfiança. Holanda sugeriu, pois, sobre o autor de Lusíadas, que "contribuiu antes para desfigurar do que para fixar eternamente a verdadeira fisionomia moral dos heróis da expansão ultramarina” (HOLANDA, 1999, p. 114). Quanto à Literatura brasileira dos oitocentos, num mesmo sentido, pontuou, páginas adiante:

Tornando possível a criação de um mundo fora do mundo, (...) não tardou em instituir um derivativo cômodo para o horror à nossa realidade cotidiana. Não reagiu contra ela, de uma reação sã e fecunda, não tratou de corrigi-la ou dominá-la; esqueceu-a, simplesmente, e detestou-a (HOLANDA, 1999, p. $162)$.

Ora, referindo-se à escrita daqueles literatos portugueses e à produção dos românticos do Brasil do século XVIII, ele considerou um mesmo aspecto como recorrente e fundamental: o descolamento da produção poética no que tange à realidade psicossocial. 
Não é curioso que desses dois momentos em que abordava a Literatura Holanda igualmente partisse para pregar a necessidade de focar a "realidade"? Não é possível que, assim, ele retemesse à pretensão, apontada como corrente entre os literatos regionalistas nordestinos, de tomar como tema o Brasil real? Eu diria que sim. Cabe avaliar, contudo, ainda, em que medida tal tese de Raízes - para além de característica da experiência de Holanda como crítico literário, e como intelectual dos anos 1930 - correspondia, também, a um desdobramento de suas experiências especificamente entre os modernistas de São Paulo.

Desde já, cabe definir: o modernismo, tantas vezes apresentado pelos críticos e pesquisadores como uma iniciativa intelectual/literária una e nacional, deve ser trabalhado como mais uma iniciativa entre tantas, do período, ademais de plural (CASTRO, 2009, p. 203).

Daqui em diante abordarei tais questões, ponto a ponto: variações nas intenções, interesse pelo real/presente, interesse pelo nacional, e interesse pela realidade histórica e contemporânea.

Holanda se referiria à já aludida Semana da Arte Moderna como "um toque de reunir, (...) que marcou, de fato, o primeiro encontro do modernismo com o público" (Apud. COUTINHO: 260). Porém, em entrevista de 1925, Prudente de Morais, neto, ao lado de Holanda, já abordava a tal diversidade modernista da seguinte maneira:

Uma das críticas mais absurdas que nos têm sido feitas é a que nos censura por falta de coesão, de unidade de vistas, de regras e um fim comum que se possa reconhecer imediatamente. Querem que o modernismo seja uma escola quando é um estado de espírito (Apud. BARBOSA, p. 74).

Holanda pontuaria que as distensões entre os intelectuais envolvidos na Semana se faziam cada vez mais graves desde 1924. Isso pode parecer um tanto despropositado, já que, precisamente nesse ano, um dos nomes mais importantes do modernismo, por ser um escritor já consolidado, e inclusive integrante da Academia Brasileira de Letras, o maranhense Graça Aranha, rompeu formalmente com a dita instituição; atraindo ainda mais atenção para o grupo. Nesse ano, também, Oswald de Andrade publicou um de seus textos mais importantes e comentados - o Manifesto pau-brasil.

Para Holanda, efetivamente,

o célebre episódio [em que] Graça Aranha saiu triunfalmente carregado por Alceu Amoroso Lima e Murilo Araújo e ainda escorado por Prudente de Morais, neto, suge[ria] à primeira vista a persistência desse cunho unitário em que parecia fixado o movimento modernista a partir da Semana da Arte Moderna. Longe, porém, de significar o coroamento de uma perfeita harmonia de intenções e de propósitos entre os participantes da revolução, esse episódio represent[ária], a bem dizer, uma última e desesperada 
tentativa para sustar a inevitável deterioração daquela unanimidade superficial e, em suma, fictícia (HOLANDA, 1979, p. 273).

Ademais, a publicação do referido manifesto, por Oswald, expressava justamente a definição de um programa que rompesse com o programa de Graça Aranha. Conforme Silviano Santiago, "no artigo Modernismo atrasado, publicado em 1924, Oswald havia dito categoricamente: 'Graça Aranha é dos mais perigosos fenômenos de cultura que uma nação analfabeta pode desejar'” (Apud. SANTIAGO, 2005, p. 9).

Foi, enfim, sempre interessado na pluralidade de propostas que caracterizava o conjunto rotulado "modernista", que Holanda se juntou ao amigo de faculdade, Prudente de Morais, neto, entre os anos 1924 e 1925, para editar Estética. Conforme declarou anos mais tarde, o propósito da revista era "abrigar as mais diversas expressões do modernismo" (HOLANDA, 1979, p. 276). Conforme Maria Célia de Moraes Leonel, era trabalhar algo como uma "história do modernismo". Num novo momento do movimento artístico-literário, corresponder menos a um manifesto do que a uma crítica dos procedimentos; promover menos desconstrução de perspectivas, do que bases para um posicionamento crítico ante elas (LEONEL: 14).

Afrânio Coutinho considera que, a partir da Semana da Arte moderna, e através dos anos 1920 e 1930, cinco grupos de intenções literárias foram se estabelecendo: o dinamista, o primitivista, o desvairista, o nacionalista e o espiritualista.

O grupo dinamista, para além de terras paulistas, encabeçado por Graça Aranha, ao ver de Coutinho se definiria pelo "culto do movimento e da velocidade" modernos e nacionais; grupo desvairista, encabeçado por Mario, "batia-se pela liberdade de pesquisa estética"; o grupo primitivista, encabeçado por Oswald de Andrade, se destacaria pela inspiração "nos motivos primitivos da terra e da gente brasileira"; o grupo nacionalista, do qual se destacava o outro autor interessado pelo conceito de "cordialidade", aludido no primeiro Capítulo desta Tese, Cassiano Ricardo, se tornaria célebre por flertar com doutrinas totalitaristas; e o grupo dito "espiritualista" corresponderia aos editores da revista carioca Festa, identificados com o simbolismo oitocentista, dentre os quais o mineiro Murilo Mendes (COUTINHO, p. 270271).

Haveria, ainda, para Coutinho, o "grupo dos independentes" - quer dizer, autores que costumavam dialogar com todos, mas não se associar a ninguém, dentro os quais os já mencionados Ribeiro Couto, Holanda e Morais, neto; e ainda o pernambucano Manuel Bandeira e Sergio Milliet (Idem, p. 270-271). 
Ora, em memorável texto publicado na Revista do Brasil, Holanda rompeu com muitos desses grupos referidos por Coutinho - o nome de tal artigo era $O$ lado oposto e outros lados; e o ano, conforme aludido linhas antes desta seção, 1926.

Em tal oportunidade Holanda classificou os modernistas dinamistas como "acadêmicos", continuadores da "literatura 'bibelô', que nós detestamos"; e os criticou por “idealizarem (...) a criação de uma elite de homens, inteligentes e sábios, embora sem grande contato com a terra e o povo". Aos desvairistas, elogiou as "tentativas de nobilitação da fala brasileira" comum, diária, popular, mas apontou que, pela "atitude intelectualista", passara a lhe "desagradar".

Aos nacionalistas, que se ordenariam em grupo Verde-amarelo e grupo Anta nos anos seguintes (1927 e 1928, respectivamente), antecipou, inconsciente, sua "revolta contra muitos que acreditam possuir [a expressão nacional] tal e qual deve ser" (HOLANDA, 1996, p. 227).

Ele apontou, então como "preferidos" alguns autores isolados, como Oswald, Prudente de Morais, neto, e Manuel Bandeira. Mencionou também Ribeiro Couto, que, como vimos, foi o criador da expressão "homem cordial", posteriormente explorada e desdobrada por Holanda, em Raízes.

Porém, fato é que esse quadro não esteve estruturado desde a Semana da Arte Moderna, de 1922. Naquele momento inicial, alguns expoentes desses grupos apresentaram proposições um tanto distintas. Por exemplo: costuma-se dizer que, a princípio, se teriam caracterizado pela busca por uma Literatura nova, e pela consideração da realidade moderna, literariamente; e que apenas no final dos anos 1920 se teria fortalecido o desejo de compor uma Literatura autêntica, nacional.

Partindo dessa abordagem, podemos dizer que os idealizadores da Semana foram, pois, chamados "futuristas", porque era comum, à época, assim denominar-se qualquer intenção de vanguarda que se aproximasse do projeto de Tomaso Marinetti, na Itália, dito "futurista", de incorporar à Literatura o tema da cidade, da máquina, das paisagens modernas. Em 1909, Marinetti havia divulgado, na Europa, um manifesto em que constava a ideia de uma Literatura que cantasse "a beleza da velocidade", "as grandes multidões movimentadas pelo trabalho", "as vibrações noturnas dos arsenais e dos estaleiros", "as usinas suspensas nas nuvens de suas fumaças" (Apud. TELES, p. 116).

Senão, vejamos que pontos de contato Mario, Oswald, e também Graça Aranha apresentaram, num primeiro momento, com o futurismo.

Mario, em Paulicéia desvairada, tomou como tema o viver na capital do modernismo brasileiro: citou lugares frequentados, descreveu paisagens frenéticas, o tumulto de gente, o 
clima, o tempo, barulhos da cidade, tipos sociais (como o burguês, a imigrante operária), "futilidade, civilização" (ANDRADE, 1980, p. 40). E Oswald, em Manifesto pau-brasil, clamou como tema da nova Literatura: "as novas formas da indústria, da viação, da aviação", "postes, gasômetros, rails, laboratórios e oficinas técnicas", "vozes e tiques de fios e ondas e fulgurações”, “estrelas familiarizadas com negativos fotográficos” (Apud. TELES, p. 476).

Holanda diria anos, anos depois, que lhe incomodara a preocupação de Graça Aranha com determinados clichês de brasilidade, como o carnaval, a "perpétua alegria", o tropical, que, por acaso, embutiam certa referência ao futurismo, por remeterem a um interesse pelo dinâmico, por uma comoção transbordante, por "espetáculos mais visíveis e radiosos do mundo exterior" (HOLANDA, 1979, p. 24-25).

Ao que tudo indica, tal preocupação com a modernidade como tema literário se deu também em Holanda, quando jovem crítico literário. Porém, só começou a se manifestar após o contato com os modernistas; e sempre contraposta à preocupação em não incorrer em simples esteticismo.

Antes do contato com Mario, Oswald, entre outros, em artigos tais como seu artigo de estreia, Originalidade literária, de 1920, nada havia proposto sobre a possibilidade de uma Literatura fincada naquele dado tempo histórico (Idem, p. 35-41).

Nos artigos pós-1922, a distinção é notável. Lê-se, daí em diante, Holanda lamentar que o leitor brasileiro fosse tão "moderno em vida e passadista em arte" (Idem, p. 114); e apontar a necessidade de se lutar por uma poesia que tivesse "razão de ser e relação com os valores sociais correntes" (Idem, p. 142), uma "poesia do prosaico", uma "poesia do cotidiano" (Idem, p. 186).

Entretanto, houve em Holanda como outros elementos do modernismo brasileiro a preocupação de se afastaram da ideia de uma Literatura nova tão somente por trabalhar o tema da modernidade. Conforme Mario (1980, p. 29), no Prefácio interessantíssimo, que abria Paulicéia desvairada, "escrever arte moderna não significa (...) representar a vida atual no que tem de exterior: cinema, asfalto". Quanto a Oswald (2009, p. 354), defendeu, no mesmo Manifesto Pau-brasil, que "a poesia está nos fatos"; mas também que os fatos fossem abordados de uma forma distinta do Naturalismo - "pela síntese", "invenção", "surpresa".

Desde seus primeiros artigos, divulgados na imprensa brasileira, Holanda criticava a tecnificação/impessoalização de toda espécie de elaboração humana: desde o trabalho na indústria e no campo, ao trabalho intelectual. Escreveu, por exemplo, em O homem-máquina, de 1921: “A pouco e pouco se vão dispensando os tenores, que os gramofones vão substituindo. Em breve não será mais impossível à máquina de raciocinar a Ars Magna de 
Raimundo Lullo, máquina como só poderiam os modernos conceber, com porcas, parafusos, rodas dentadas, a eletricidade ou vapor" (HOLANDA, 2011, p. 16).

A partir do contato com os modernistas, pois, passou a propor que a nova Literatura se desse como um mergulho na modernidade pela via pessoal, subjetiva. De acordo com Leonel, teria declarado, pois, que "a atitude atual do homem em face do mundo e dos problemas que hoje nos atormentam e a expressão dessa atitude é que constituem o modernismo" (Apud. LEONEL, p. 19).

Referiu-se, a propósito, a Cidade do vício e da graça: vagabundagem pelo Rio noturno, como um livro que cumpria tal projeto, por não apenas tratar do atual e do real, mas também por corresponder à revelação subjetiva dessa atualidade, dessa realidade. Tratava-se do livro de poemas lançado em 1924 por Ribeiro Couto; autor santista pouco mencionado nos estudos sobre o modernismo, e que, contudo, como temos visto, sempre intrigou Holanda (HOLANDA, 1996, p. 186).

Diz-se que Holanda foi um profundo interessado pelo instintivo, aleatório, espontâneo, surreal; e que uma das provas da maior importância conferida por ele, quando jovem, a tal universo de questões é um artigo de 1925, intitulado Perspectivas, no qual ele declarou: "só à noite enxergamos claro" (Idem, p. 216).

Porém, a meu ver, a leitura completa desse artigo, a começar pelo título, e também outros artigos da época, nos indica certo equilíbrio entre o interesse de Holanda pela concepção de "realidade" e de "subjetividade"; a articulação entre as ideias de "real" e "ficção", "experiência" e "elaboração". ${ }^{13}$

A leitura de Perspectivas, especificamente, me parece mais do que pontuar o flerte de Holanda com concepções irracionalistas, indicar o mapeamento, por ele, do entendimento de que não haveria vida e manifestação, de forma separada - mas tão somente "manifestação de vida". O entendimento de que abordar o real, "procurar a realidade", era "adquirir pensamento", “confessar"; de que o real se captaria pelos olhares, pelos modos de entender,

\footnotetext{
${ }^{13}$ Não cabe aqui alongar-me, mas eu defenderia, ao contrário do que tem sido apontado pelos críticos de Holanda que, dentre todas as vanguardas europeias, aquela com a qual Holanda teria mais se identificado não foi o surrealismo francês. Foi o expressionismo alemão, a que ele dedicou um externo artigo, publicado antes mesmo da viagem à Alemanha, em 1922. Em O expressionismo, Holanda afirmou que tal movimento "não correspond[ia] apenas a uma simples forma pictural ou mesmo literária"; equivaleria a "todo um novo sistema de vida" - uma nova conduta, notável e explorável na e pela arte, e também "em filosofia como em sociologia" (HOLANDA, 1996, p. 157). O expressionismo era, a seu ver, a valorização não apenas da maneira como os indivíduos percebem o mundo (a qual caracterizara o impressionismo), nem de como escapam (o surrealismo) mas da maneira como os indivíduos o sentem e pressentem; uma criação que tomaria em conta tanto o real, quanto o real como criação subjetiva.
} 
conforme as "perspectivas", subjetivas, de cada autor, pensador, literato, analista, crítico (Idem, p. 217).

Outro ponto que aproxima as elaborações de Holanda, em Raízes, da produção e das reflexões de Mario e Oswald é o interesse pela psicologia/psicanálise. Creio que a maneira como o futuro autor de Raízes e tais poetas observaram as formulações de Freud foi diversa.

No Prefácio interessantíssimo, o primeiro desses autores escreveu:

Dom Lirismo, ao desembarcar do Eldorado do Inconsciente no cais da terra do Consciente, é inspecionado pela visita médica, a inteligência, que limpa dos macaquinhos e de toda e qualquer doença que possa espalhar confusão, obscuridade na terrinha progressista. Dom Lirismo sofre mais uma visita alfandegária, descoberta por Freud, que a denominou Censura. Sou contrabandista! (ANDRADE, 1980, p. 27-28).

Mario falava, assim, do lirismo como fator nascido no inconsciente, e que passaria por um processo de perdas quando manifestado através da escrita, já num nível de consciência; contudo, considerando-se "contrabandista", pontuava o esforço por uma poesia instintiva, de expressiva e liberdade.

Num sentido semelhante, no Manifesto Antropófago, de 1928, Oswald defendeu uma "mentalidade pré-lógica" e criticou "a realidade social, vestida e opressora, cadastrada por Freud" (ANDRADE, 2009, p. 273).

Para Holanda, distintamente, desde seus primeiros artigos, o inteligível não poderia ser posto de lado. Ele afirmou, por exemplo, no artigo de 1921 aqui já aludido, que centrar-se no irracional, impulsivo, era reafirmar uma lógica materialista vulgar, a ser desprezada, senão "o homem fará tudo por instinto, não procurará a causa de nada, não raciocinará", e se "anulará" (HOLANDA, 2011, p. 18).

Afinal, a psicologia/psicanálise alemã/austríaca/suíça, com a qual parece ter dialogado desde jovem até a composição de Raízes, embora se interessasse pelo inconsciente, pretendia ir além dos comportamentos aparentemente aleatórios, e estabelecer padrões de entendimento mais ou menos lógicos, ou racionais, científicos/acadêmicos, sobre as personalidades.

Note, então, que o diálogo com a psicanálise também explicava a percepção crítica de Holanda, em O lado oposto de outros lados, no que diz respeito à abordagem do nacional, corrente na produção de muitos dos modernistas. Nesse artigo, como vimos, ele revelava considerável receio ante as proposições de dinamistas, decadentistas e nacionalistas, pela abordagem poética que operavam, em meados da década de 1920, do homem e da cultura brasileiros, e que tendia a ser redutora. Tal como um psicanalista, criticava sem apontar saídas estereotipadas; concordava com a importância de pensar sobre a arte produzida no Brasil, mas 
“mandava pro diabo qualquer (...) política literária”, qualquer definição apriorística do que essa arte deveria vir a ser (HOLANDA, 1996, p. 224).

Hora de nos concentrarmos, pois, na abordagem proposta pelo heterogêneo grupo modernista, a respeito da nação brasileira, daquelas primeiras décadas do século XX.

Fato é que passado um primeiro movimento de interesse explícito por uma Literatura que rompesse padrões de escrita, e pela novidade do Brasil moderno, muitos dos modernistas brasileiros se engajaram em projetos variados de uma Literatura nova porque nacional - que considerasse temas locais, e um modo de se expressar tipicamente nosso. Paulo Prado e seu Retrato do Brasil, por exemplo, deve ser lido nesse contexto.

Esse deslocamento é também bastante notável nas publicações de Mario, que se ocupou de uma escrita telegráfica, sobre a capital paulista, nos poemas de Paulicéia desvairada, mas se revestiu de intenções brasilianistas nos versos de Losango cáqui, de 1924, e consolidou a tendência em Clan do jaboti, de 1927. De 1928, é o livro que Oswald consideraria, por fim, o mais significativo de todo o modernismo; e que teria sido elaborado a partir de alguns dados apresentados em Retrato do Brasil, por Paulo Prado, a quem, afinal, Mario o dedica - refiro-me a Macunaíma: o herói sem nenhum caráter (Apud. CALIL, p. 42).

Eis, aqui, afinal, um bom momento para contar que, quando no México comentava que pretendia comparar o "pelado" com um "tipo" formulado por um autor brasileiro, contemporâneo a Ramos, costumavam me perguntar se esse "tipo" era Macunaíma, e tal autor, Mario de Andrade. Ante a insistência dos professores mexicanos, passei a me questionar: Teriam eles alguma razão em considerar Macunaíma um "tipo" brasileiro, tal como o "homem cordial", de Holanda? Tal personagem de Mario compreendeu a um desejo do autor por apresentar um referencial a partir do qual se pudesse considerar o brasileiro real, contemporâneo, em suas diversidades, alterações, e permanências históricas?

Se acompanharmos algumas declarações de Mario, podemos responder que sim. Mario afirmou, em carta a Bandeira, de 1927, que não entendia o personagem do livro que viria em breve a publicar como incorporação da psicologia nacional geral. A seu ver, "Macunaíma é ora corajoso, ora covarde. Nada sistematizado em psicologia individual ou étnica"; quer dizer, tem um tanto do brasileiro em si, evoca ao brasileiro, mas não contém todo o Brasil. "Símbolo em arte não é simbolismo", dizia, "mas síntese [que] vive por si” (Apud. MARTINS, p. 7677).

Silviano Santiago, em Raízes e labirintos da América Latina, aborda a opção de Holanda por compor um "tipo" único brasileiro, para análise de um coletivo complexo; e conclui que o "homem cordial" deveria ser por nós compreendido como - tal como, eu diria, 
Macunaíma - um "personagem complexo", conceito proposto de E. M. Foster, em Aspectes of the novel (1926). Deveria ser considerado, diz Santiago, como "um alguém que, [numa obra literária,] sendo singular" incorpora características de todo um "catálogo informe e anárquico" de procederes, e que, entretanto, "é capaz de surpreender o leitor de maneira convincente", como se correspondesse a um indivíduo cuja existência é realística, verossímil (SANTIAGO, p. 23).

Santiago, em outro estudo, um artigo intitulado Mário, Oswald e Carlos, intérpretes do Brasil, de 2005, apontou, porém, a possibilidade de identificarmos maiores intersecções entre a escrita de Holanda, em Raízes, e as formulações de Oswald. Perguntou-nos: "O Sérgio Buarque de Holanda, de Raízes do Brasil, estaria em parte embutido em Oswald de Andrade?" (Idem, p. 5).

Em tal texto Santiago não vai em busca de uma resposta especificamente para essa questão, mas apresenta alguns elementos que podem, nesse sentido, nos ajudar. Para ele, Oswald deve ser considerado como um intérprete do Brasil que, abordando criticamente a questão da "herança cultural", foi além da "pesquisa estética" e da "nobilitação" da fala brasileira, e se preocupou com as condições de "aclimatação" do "primitivismo" à “civilização" (SANTIAGO, 2005, p. 9). E em Raízes o mote principal não era justamente a condição de transplantação/implantação de uma determinada cultura, a europeia, a um determinado território, americano, nos primeiros momentos da modernidade, até os dias atuais?

Eu diria, então, que por mais que Mario e Oswald tenham se esforçado, a princípio, em seus textos mais conceituais, em criticar sistematizações, acabaram, em suas composições literárias, por se entregar a procederes bastante sistemáticos. E nisso se aproximavam e diferenciavam de Holanda, de forma tensionada, e confusa, por ele, desde seus artigos de crítica literária, da juventude, até a composição do célebre ensaio, de 1936, desejou uma avaliação racional do passado e do real, e uma arte livre, espontânea, sem programa.

Destarte, a despeito de suas intenções e posicionamentos políticos, às composições dos literatos mais comemorados de nossa vanguarda passou exatamente o que Holanda parecia temer: acabaram por servir ao governo ditatorial logo instituído. Segundo Nicolau Sevcenko, Mario e Oswald

projetariam todo seu entusiasmo na celebração de um passado mítico, préhistórico, o qual transformariam na sua plataforma estética. Essa mitologia de origens se desdobraria por sua vez para um futuro idealizado, concebido como uma estetização da cultura brasileira 'pura', pressuposto de uma nova harmonia e plenitude social, sem conflitos, opressões, exclusões. (...) Getulio Vargas não apenas compreendeu os potenciais desse novo imaginário, como 
logo nos primeiros discursos exaltando a vitória do golpe de Estado avocava a si a paternidade da criança recém-nascida. 'As forças coletivas que provocaram o movimento revolucionário do modernismo na literatura brasileira, que se iniciou na Semana da Arte Moderna de 1922, em São Paulo, foram as mesmas que precipitaram, no campo social e político, a Revolução de 1930', disse (Apud. SEVCENKO, p. 318).

Quanto ao "grupo independente", indicado por Coutinho, vimos a identificação entre Holanda e Prudente de Morais, neto, e Ribeiro Couto. Hora de abordar possíveis relações entre seus modos de entender e concepções do escritor nordestino, sempre presente em São Paulo, e radicado no Rio de Janeiro, Manuel Bandeira.

Bandeira, tal como Graça Aranha, não era paulista e contava maior idade que os demais modernistas, mas esteve junto a eles desde a Semana da Arte Moderna, de 1922. Diferentemente do poeta maranhense, contudo, não chegou a desejar fundar ou liderar ou mesmo integrar um ajuntamento de poetas, romancistas, artistas. Produziu sempre em contato com os amigos, mas de forma muito pessoal, e - para utilizar um termo seu - "libertina". Seria, conforme o diagnóstico de Holanda, em O lado oposto e outros lados, "o melhor poeta brasileiro se não existisse Mario de Andrade" (HOLANDA, 1996, p. 228).

Bandeira explorou, nos diversos livros publicados ao longo das décadas de 1920 e 1930, aos mais distintitos temas, incluindo renovação estética, seu Nordeste de origem, a casa-grande e a senzala estudadas por Freyre, o carnaval brasileiro, e também um grave sentimentalismo, introspectivo. Por ocasião da publicação do Manifesto pau-brasil, declarouse, então, irritado com o que considerava a definição de como proceder literariamente, e com a insistência com o tema nacional. Lembrando bastante, pois, a abordagem que aqui estou proposto a respeito dos posicionamentos de Holanda, Bandeira escreveu, em carta datada de 1924:

Oswald de Andrade acaba de deitar manifesto - uma espécie de plataformapoema daquilo que chama Poesia Pau-brasil. Eu protesto. O nome é comprido demais. Bastaria dizer poesia pai. Por inteiro: Manifesto da Poesia Pau. Porque é poesia de programa e toda arte de programa é pau. Aborrecem os poetas que se lembram de nacionalidade quando fazem versos. Eu quero ser eventualmente mistura de turco com sírio-libanês. Quero ter o direito de falar ainda na Grécia. Há pouco tempo entre na Agência Havas no momento em que Américo Facó ditava pelo telefone um despacho recebido de Eulêusis. Senti de pronto a ironia da emoção lírica. Não podia evidentemente falar de Tabatinguera (Apud. BORGES PINTO, p. 454).

É claro que Holanda não mencionou, em O lado oposto e outros lados, o projeto de Festa, revista carioca, rotulada como iniciativa "espiritualista", por Coutinho. Festa apenas foi lançada no ano seguinte à publicação desse artigo, quer dizer, em 1927. 
Entretanto, considero que se pode observar identificações entre as tais concepções de Holanda, que iam ao encontro das ideias de Bandeira, e as proposições dos editores daquele periódico.

Conforme Ângela de Castro Gomes, os responsáveis por Festa estiveram, vez ou outra, envolvidos em reflexões sobre contemporaneidade e brasilidade, mas "propugnavam uma orientação moderna sem radicalismo, o abandono do pitoresco e [se voltavam ao] cultivo dos temas e valores universais" (GOMES, 1996: 99).

Confirma tal hipótese o poema Intróito, que abre Definição do Modernismo (1932), de Tasso da Silveira, um dos grandes nomes de Festa. Ali, o autor trabalha com a ideia de "realidade total" - “corpo", "espírito", "natureza", "sonho", “instinto", “inteligência” como temas variados, a serem explorados, livremente, pelos autores brasileiros (Apud. TELES, p. 467).

Assim, podemos identificar a experiência modernista de Holanda não apenas como reafirmadora do interesse pelo Brasil, mas, em alguma medida, da compreensão do Brasil como uma experiência viva, e não como uma construção; e do brasileiro como problemático por evitar conceber-se como universal.

Nesse sentido, Alexandre Eulálio e Antonio Candido defendem que Holanda - tal como alguns dos modernistas, individualmente ou em grupo - não apresentou propriamente, em Raízes, a composição de uma psicologia nacional, ou de uma referência de brasilidade. Teria buscado refletir "filosoficamente" sobre as referências postas - o primeiro fala de uma “conotação filosófica”, em Raízes (EULÁLIO, p. 258); e o segundo, que "Raízes do Brasil (...) tem muito, com certeza, de sociologia da cultura, outro tanto de história das mentalidades e costumes, mas possui igualmente uma vocação de filosofia" (CANDIDO, 1998, p. 97). 


\subsection{A vanguarda literária no México}

Como propus em seções anteriores, não constitui tarefa fácil localizar Ramos em um grupo intelectual, do México das primeiras décadas do século XX. Até onde vimos, no que diz respeito ao ensaísmo mexicano deste período, ao mesmo tempo em que seu trabalho é largamente associado, por muitos de seus estudiosos, ao do Ateneo de la Juventud, a leitura de sua obra, e de artigos por ele publicados na imprensa, nos revela que ele foi crítico a concepções e atuações de seus mestres ateneístas.

Busco, então, possíveis conexões entre Ramos e os literatos mexicanos do início dos novecentos. Antes, porém, penso ser interessante avaliar possíveis relações entre o ensaísmo e a produção literária.

Em textos divulgados em revistas e jornais, na década de 1910, Caso já destacava a importância da linguagem poética. Dizia no já aludido artigo, El bovarismo nacional, de 1917, que "la poesia es más seria y profunda que la historia", porque, a seu ver, enquanto a História abordava questões contingentes, a Literatura equivaleria à transmutação de intuições pessoais e momentâneas em valores atemporais, sentimentos absolutos (CASO, p. 22).

Em outro artigo do mesmo ano, Caso seguiria defendendo a ideia de que o rigor científico era limitador do pensamento, e de que a arte deveria ser preocupação primordial do filósofo: "Un pueblo que se educa no más en la ciéncia, es un pueblo sin entusiasmo, sin ideal. La ciéncia es puro egoísmo". Já a arte, a seu ver, “educa el espíritu en la despreocupación de uno mismo, en la 'proyección' del alma al exterior, en [generosa] la contemplación (...) de la existéncia" (Idem, p. 51).

Quanto a Ramos importante sublinhar que conexões ente Literatura/arte e História/filosofia podem ser notáveis não apenas em El perfil, mas em livros posteriores, como Filosofía de la vida artística (1950), e Nuevo ensayo sobre Diego Rivera (1959); e em todo um direcionamento de suas reflexões ao tratamento do "estético".

Quanto aos literatos mexicanos do período tidos como mais expressivos, cabe considerar: Mariano Azuela, autor de Los de abajo (1915), e Martín Luis Guzmán, autor de El águila y la serpiente (1928) e La sombra del caudillo (1929). Adiante também me referirei a expoentes da vanguarda.

Azuela foi um culto médico maderista, posteriormente integrante das tropas de Julian Medina, general de Pancho Villa; e compôs um relato ficcional a partir de suas experiências.

Guzmán também esteve entre os homens em campanha, mas sua produção se difere da dita obra de Azuela por dois motivos: abordou "los de arriba", quer dizer, grandes 
personagens ou supostos grandes personagens da história da Revolução; e escreveu quando a Revolução já entrava no período de institucionalização. La sombra del caudillo é uma novela; El águila ya la serpiente, narrado em primeira pessoa, se aproxima mais do tom memorialístico, entretanto, dialoga com a ficção - Guzmán mesmo a considerava "una novela, la novela de un joven que pasa de las aulas universitárias a pleno movimiento armado; [que] cuenta lo que El vio en la Revolución tal cual lo vio, con los ojos de un joven universitario" (CARBALLO, 2001).

Importante sublinhar, a propósito, que raramente se inclui o nome de Guzmán entre os ateneístas; mesmo Ramos, que em El perfil apresenta uma larga listagem de integrantes do Ateneo, não o cita (RAMOS, p. 135).

Decerto, as relações entre Guzmán e esse grupo se revelaram com o correr dos anos pouco harmônicas. Como indicam cartas trocadas entre eles na década de 1920, estudadas por Carlos Betancourt Cid, o dominicano Ureña, por exemplo, tendeu a criticar pesadamente a relação de Guzmán com governos ditos "revolucionários", pedidos de ajuda financeira para bancar os periódicos que lançava, negociações de saída para o estrangeiro em condições vantajosas. Betancourt lembra ainda que a leitura das referidas missivas nos relevam que Vasconcelos teria rompido com Guzmán por um motivo, digamos, mais fútil e não menos nodal: Guzmán acabou por envolver-se com a amante de Vasconcelos, de codinome Adriana (BETANCOURT CID, 2010).

Mas Guzmán declarou, em clássica entrevista concedida a Emmanuel Carballo, em 1958, que esteve em contato com os ateneístas desde o ano de 1908, quer dizer, antes mesmo de - conforme Curriel Defossé - Vasconcelos começar a visitá-los. Guzmán foi, à época, amigo íntimo de Caso, Reyes e também Ureña (CARBALLO, 2001).

Ademais, lembremos que em 1916, em um artigo intitulado El movimiento intelectual contemporáneo de México, Vasconcelos não poupara elogios a Guzmán, como integrante do Ateneo: o definiu como um "espíritu claro y viguroso que pronto habrá de definirse con inconfundible relieve" (VASCONCELOS, 1992, p. 35).

Por fim, consideremos, também com Curriel Defossé, que há contradições acerca da autoria do projeto da aqui já aludida Universidad Popular ateneísta. Mas que muitos testemunhos indicam que teria sido criada não por Vasconcelos, mas por Albert Pani e Martín Luis Guzmán (CURRIEL DEFOSSÉ, 1998).

Quando conflitos armados arrasaram a capital no ano de 1913, e muitos dos envolvidos no projeto ateneísta partiram para outros países, Guzmán optou por integrar as tropas revolucionárias. Sim, enquanto Pani, Ureña e Reyes migravam para o estrangeiro, 
Guzmán seguia para o norte do país, para atuar como uma espécie de agente secreto de Pancho Villa, função que lhe permitiria alcançar conhecimentos e entendimentos acerca do México que os demais ateneístas talvez não tenham podido alcançar (TORRES AGUILLAR, 2010a: 165). Sim, Guzmán passou a ser conhecido em todo o território nacional; na capital, e também cem estados vizinhos, como certamente o Michoacán de Ramos.

Partindo de todas essas informações, pois, podemos propor que Ramos foi leitor de Guzmán. Sim, se Ramos foi crítico do utopismo do Ateneo e desejou intelectuais, para o México, que possuíssem maior conhecimento real do país, e um sentido mais prático da vida, dificilmente o autor de La sombra del caudillo tenha deixado de despertar nele alguma identificação, tal como Vasconcelos. "Entre los ateneístas, sólo Vasconcelos y Guzmán participaron activamente de la guerra civil", lembra Christofer Domingues Michael (MICHAEL, p. XXI).

Ademais, tenhamos em mente que Guzmán, tanto em El águila y la serpiente como em La sombra del caudillo, apresentou avaliações bastante severas dos líderes e do Estado dito revolucionários. Sim, não importa que, nas palavras de Beatriz Alcubierre Moya e Jaime Ramírez Garrido, ao final de sua vida Guzmán tenha se "reconciliado con el regimen" (ALCUBIERRE \& RAMÍREZ, 2011). Fato é que, quando Ramos começava a escrever sobre o homem e a cultura mexicanos, Guzmán se encontrava na Espanha, foragido do governo revolucionário instituído, por ter apoiado as forças rebeldes do general Adolfo de la Huerta. Fato é que, tal experiência e sua decepção com o movimento revolucionário, revultaram em críticas apreciações, constantes nos dois livros supracitados, publicados no exílio espanhol; e que essas apreciações, de algum modo, se aproximavam das de Ramos, em El perfil.

Ao ver da professora Susana Quintanilla, Guzmán foi “el ultimo gran liberal” (QUINTANILLA, 2009). De maneira que creio ser razoável dizer que o Guzmán das décadas de 1920 e 1930 pode ser localizado no mesmo entre-lugar de Ramos: ambos são liberais, e críticos da Revolução como processo violento e como imposição de um grupo, alienado em relação aos interesses da maioria. Considero, pois, que, se Guzmán não foi em El perfil uma referência mencionável, isso se deu em razão de que era a Vasconcelos que Ramos queria como amigo próximo; mas que semelhanças entre tal obra e La sombra del caudillo não podem ser explicadas como fruto de mero acaso.

No México, a vanguarda literária se fez expressiva através da atuação e produção de duas facções: os integrantes do estridentismo; e os editores da revista Contemporáneos, que embora sejam considerados conjunturamente por sua fortuna crítica, à época se esforçaram por dizer que não correspondiam a um grupo. Assim, há aqui um quadro oposto ao observado 
nas seções anteriores, a respeito do ensaísmo brasileiro e mexicano: no Brasil, a vanguarda tem sido vista como um grupo mais ou menos coeso (embora não tenha sido), e o ensaísmo, não; no México, a vanguarda tem sido vista como um movimento disperso, e o ensaísmo, não (embora tenha sido marcado por discrepâncias).

Como nos conta Francisco Javier Mora, o estridentismo começou por iniciativa do veracruzano Manuel Maples Arce, que divulgou, em 1921, na Cidade do México, um manifesto em defesa da renovação dos paradigmas literários - Actual $n^{o} 1$ : hoja de vanguardia, comprimido estridentista (MORA, p. 262). O dito manifesto era simbolicamente assinado por um "Directorio de Vanguardia", que nada mais era do que uma lista de autores e artistas, nacionais e estrangeiros, com os quais Maples particularmente se identificava. Ademais, segundo Ida Rodríguez Prampolini, o papel continha uma foto do poeta, denotando tratar-se de um projeto individual (PRAMPOLINI, p. 138).

Mas ali se propunha não um desenho de rota particular, mas um programa-estético que promovesse a ampla generalização de inovações na forma e no conteúdo da Literatura no México; que rompesse com a poesia oitocentista mexicana, dita modernista, da qual se destacava o nome de Enrique González Martínez (Apud. MESQUITA, p. 249).

A ideia era que os jovens literatos, em suas composições, estivessem mais atentos às dinâmicas da cidade moderna, à velocidade, às máquinas, aos ruídos estridentes. O próprio fato de numerar-se - de denominar-se " $\mathrm{n}{ }^{\circ} 1$ " - podia soar como um convite a possíveis futuros adeptos (Idem, p. 243).

Cabe, então, transcrever uma passagem interessante do dito manifesto, na qual Maples declara convocar "todos los que no han ido a lamer los platos en los festines culinarios de Enrique González Martínez, para hacer arte (!) [sic] con el estilicidio de sus menstruaciones intelectuales, a todos los grandes sinceros" (Idem, p. 248-249).

As adesões começaram a se oficializaram poucos meses depois, com o lançamento de uma nota, na revista Irradiador, de Puebla, assinada por Maples e Germán List Arzubide (Idem, p. 249). Ganharam maior projeção em 1923, quando ainda em Puebla se publicou um segundo manifesto, com firma de Maples, List, Salvador Gallardo, e, conforme Prampolini, mais duzentos jovens escritores, então registrados como "grupo estridentista" (PRAMPOLINI, p. 140).

Esse segundo manifesto, um tanto reduzido, mais do que definir um programa de arte nova, sublinhava o que deveria ser desdenhado, rejeitado, superado pela vanguarda poética. Ora, todos os pontos sob crítica podiam ser traduzidos como referências ao modernismo de González Martínez: às suas concepções engessadas; a seu hábito de “importación” de 
referenciais "parisienses", meros souvenirs, emblemas descartáveis; e o que os estridentistas chamaram poesia "engomada”, e "babosadas” literárias (Apud. MESQUITA, p. 253).

Era proposta do grupo, como descreveu Maples em declarações posteriores, a radicalização dos procedimentos, a subversão dos comportamentos, a ruptura com a acomodação, e até mesmo com a elegância e conformismo que caracterizara a escrita de modernistas mexicanos.

Como destaca Mora, a "acomodação" criticada pelos estridentistas fora relativamente característica também dos ateneístas, nesta Tese já aludidos. Sim, porque ainda que os integrantes do Ateneo se dissessem ou fossem considerados opositores do regime de Díaz, suas críticas haviam sido recebidas quase generosamente por considerável grupo de seus professores científicos, da Universidad Nacional; e, na corrente década de 1920, na qual os estridentistas andavam a divulgar seus manifestos, eles se haviam convertido, afinal, em certa medida, em intelectuais do governo (MORA, p. 263).

Ora, a partir de tais informações podemos operar a seguinte conclusão preliminar: o que o movimento estridentista pretendia, a princípio, era uma Literatura em formas novas, feita por gente nova, e sobre temática contemporânea.

O terceiro manifesto estridentista apareceu em Zacatecas, em 1925, e curiosamente não foi assinado por Malpes; seus autores oficiais foram: o já mencionado Gallardo, Guillermo Rubio, Adolfo Ávila Sánchez e Aldeguldo Martínez. Basicamente, tal texto retomava várias das frases-chaves do primeiro e do segundo manifestos; com uma só nova referência: a Internacional Socialista, o pensamento marxista, os ideais revolucionários russos (MESQUITA, p. 264).

Mora sublinha, oportunamente, nesse sentido, ter havido sempre uma profunda identificação entre o estridentismo e os movimentos sociais. Segundo este pesquisador, os estridentistas em geral trabalharam seus poemas e narrativas tendo em mente a necessidade de fazer "estallar las conciencias" (MORA, p. 266).

De fato, a leitura de outros manifestos, de organizações de trabalhadores operários, à época, lembram as "hojas volantes" publicadas por Maples e seus companheiros em muitos pontos - a exemplo dos Tres llamamientos de orientación actual a los pintores y escultores de la nueva generación americana, de 1921, que se desdobrou no Manifiesto del sindicato de obreros, técnicos, pintores y escultores de México o Declaración política, social y estética, de 1923 (MESQUITA, p. 240 e 254).

Voltemos, por ora, então, ao primeiro manifesto estridentista, de 1921, a sublinhar que, naquele momento, Maples havia denunciado os pensadores mexicanos que se 
comprometiam com o governo, e assim contribuíam para que cessasse ou se revertesse o processo revolucionário, no âmbito artístico. Ele convocara, naquela ocasião, para atuar a seu lado "todos los poetas, pintores y escultores jóvenes de México, a los que aún no han sido maleados por el oro prebendario de los sinecurismos gobernistas" (Idem, p. 248).

Entretanto, como conta Prampolini, os estridentistas, ao se celebrizarem como escritores de esquerda, acabaram por contradizerem as palavras do manifesto de 1921: se engajarem no projeto revolucionário do general Heriberto Jara, no estado natal de Maples, Veracruz. Maples, a partir de 1925, assumiu, pois, o posto de secretário de governo de Jara. Em tais circunstâncias, foi editado o quarto manifesto literário estridentista, no qual constam assinaturas, data e o seguinte local de edição: "Estridentópolis"; era como passava a ser conhecida a capital, Xalapa (PRAMPOLINI, p. 142).

Quando chegou 1926, afinal, o estridentismo parecia já ter alcançado a maturidade; de maneira que, nesse ano, List e Arqueles Vela publicaram relatos de suas experiências estridentistas, nos livros: El movimiento estridentista, escrito pelo primeiro, e El Café de Nadie, sobre o estabelecimento em que se conheceram e frequentaram os integrantes daquele grupo, escrito por Vela.

No mesmo sentido de balanço final do movimento, lembro que o pesquisador Fernando Fabio Sánchez, em análise de artigos publicados na imprensa capitalina do final da década de 1920, recorta um texto da época, de autoria de José Corral, no qual se afirma que, se a Revolução tinha como artista maior Diego Rivera, e como novelista mais importante Mariano Azuela, tinha como poeta mais significativo Manuel Maples Arce (SÁNCHEZ, p. 208).

Acredito ser interessante lembrar, contudo, mais um nome: o de Xavier Icaza, o prosista mais celebrado do estridentismo. De família aristocrática, tardou a abraçar os propósitos revolucionários do estridentismo, e apresentou contribuições ambíguas, ora mais ora menos radicais, politicamente falando.

No que diz respeito especificamente a sua escrita, sua participação no grupo foi fundamental. Trouxe para o centro do debate literário vanguardista uma ambientação rural não-idílica, e portanto moderna, atualizada. Conforme John S. Brushwood, foi, aliás, um dos responsáveis por tornar célebre, por fazer circular, o trabalho de Azuela; até então pouco expressivo (BRUSHWOOD, p. 160).

Conforme o historiador mexicanista canadense Serge I. Zaïtzeff, a revista Contemporáneos foi fundada em 1928 por Bernardo Ortiz de Montellano e Xavier 
Villaurrutia, e sob patrocínio do aqui já aludido Bernardo Gastelúm, subsecretário de Educación Pública.

Naquele mesmo ano Gastelún teria abandonado, contudo, o projeto. Mas o periódico seguiu sendo editado por Ortiz de Montellano e Villaurrutia, agora com o apoio do secretário de Relaciones Exteriores dos presidentes Calles, Portes Gil e Ortiz Rubio - o senhor Genaro Estrada.

Contemporáneos deixou de circular, enfim, em 1931, por falta de custeio, quando Estrada entregou o controle da dita secretaria e partiu para a Espanha, a assumir o posto de embaixador (ZAÏTZEFF, p. 310-311).

Daí podemos supor vínculos entre os intelectuais que editaram contemporâneos e o Maximato; tal como entre os estridentistas e o general revolucionário de Veracruz. Porém, entre esse outro conjunto as relações com o corpo político-administrativo em vigor foram um tanto menos claras. Avaliaremos isso daqui em diante.

Os pensadores e escritores envolvidos na publicação e circulação de Contemporáneos se caracterizavam por uma série de desentendimentos e oposições. Conforme Guillermo Scheridan, um dos mais reputados estudiosos desses intelectuais mexicanos, tal revista, mesmo após deixar de ser editada, correspondeu a "un lugar imaginário en el que coincidieron diversos discursos y maneras de ejercer el quehacer literário y cultural entre los años 1920 y 1932” (SCHERIDAN, p. 11). Por isso, diferentemente dos estridentistas, eles não foram conhecidos como grupo; receberam as designações mais variadas: "capilla", "cenáculo", "generación”, “constelación”, "máfia”, “arquipelago de soledades”, “grupo de soledades”, "grupo sin grupo".

É comum se dizer, porém, acerca desse conjunto amorfo, que havia, ali, uma linha divisória, marcando distinções geracionais. De um lado, estariam aqueles que se identificavam com Ortiz de Motellanos: Enrique González Rojo, Jaime Torres Bodet e José Gorostiza. O crítico literário Samuel Gordon descreve esses escritores como um tanto mais velhos; de cinco a dez anos, em relação aos demais (GORDON: 1902). Já o pesquisador austríaco Andreas Kurz lembra que eles se encontravam mais próximos dos ateneístas e dos poetas modernistas mexicanos, criticados por Maples, dentre os quais Enrique González Martínez, pai de Rojo (KURZ, p. 77).

Num outro agrupamento fortuito estariam poetas mais jovens, e mais próximos a Villaurrutia: Salvador Novo, Gilberto Owen e Jorge Cuesta. Conforme Gordon, além de mais jovens, deles apenas o primeiro era originário da Cidade do México; os demais haviam chegado há pouco, respectivamente, de Torreón, Toluca, Veracruz. Dentre esses escritores tal 
pesquisador inclui, ainda, Samuel Ramos, que como sabemos viera de Michoacán (GORDON, p. 1902).

De acordo com Hernández Luna, esses intelectuais mais jovens teriam sido responsáveis pela edição de uma série de outras revistas. Sob custeio de Maria Antonieta Rivas Mercado, e direção de Villaurrutia e Novo, haviam, um ano antes do lançamento de Contemporáneos, quer dizer, 1927, trabalhado pela aludida revista Ulises; na qual Ramos imprimiu os mencionados artigos contra Caso. Eles publicaram, ainda, com Jorge Cuesta à frente, em 1932, a revista Examen (HERNÁNDEZ LUNA, 1982, p. 133).

Em Examen Ramos trouxe a público outros de seus textos críticos: Psicoanálises del Mexicano e Motivos para una investigación del mexicano, no qual anunciou o projeto de lançar, em breve, um livro de ensaios sobre "el alma mexicana", sob o título El sueño de México (ARREOLA, p. 123-124). Ora, Ramos referia-se ao que seria, dois anos mais tarde, El perfil del hombre y la cultura en México.

Para Kurz, Em relação aos demais contemporáneos, esses mais jovens se caracterizavam por um certo desdém em relação aos pensadores e escritores mais conclamados no México - ícones do modernismo e do Ateneo de la Juventud (KURZ, p. 88).

Porém, me parece que, em comparação com os estridentistas, o rompimento que desenharam em relação aos mestres ateneístas foi um tanto mais sutil e ambíguo. Disso creio serem bastante representativas a amizade de Ramos com Vasconcelos, e, ao mesmo tempo, sua polêmica, com Caso.

No que diz respeito às temáticas trabalhadas, a pesquisadora alemã Vittoria Borsó propõe uma mesma noção de "sutil rompimento", entre os jovens contemporáneos e os ateneístas.

Ela destaca, do trabalho dos integrantes do Ateneo, a volta ao passado colonial como ponto de partida para a reflexão sobre o mexicano; a volta ao momento de encontro entre duas culturas como ponto de partida para se pensar a configuração de um novo ser (BORSÓ, p. 76). E defende que os contemporâneos mais próximos de Villaurrutia, embora cuidassem de abordar a cidade moderna, trataram de seguir explorando a temática dos encontros culturais; defende que eles, em seus poemas, trouxeram sempre implícita a ideia fundamental de que “entrarse a la ciudad significa (...) enfrentarse la pluralidad de la cultura” (Idem, p. 84).

Decerto, para Kurz, esses poetas possuíam um notável conhecimento das vanguardas estrangeiras, se comparados tanto aos estridentistas, como aos modernistas e contemporáneos mais velhos (KURZ, p. 88). 
Samuel Gordon conta que em uma conferência promovida, em 1924, pelo Departamento de Bibliotecas de la Secretaría de Educación Pública, dirigida à época por Vasconcelos, Villaurrutia reconheceu a importância do estridentismo como movimento de ruptura, mas apresentou tal importância como pontual, e tal iniciativa como passageira (Apud. GORDON, p. 1088).

No que diz respeito ao modernismo, tratou de ao mesmo tempo se vincular e romper com a figura de Enrique González Martínez; propôs, na ocasião, que González Martínez havia sido até então "el dios mayor y casi único", mas que era hora de valorizar a produção de uma nova leva de autores, dentre os quais convinha ressaltar os nomes de Ortiz de Montellano, Torres Bodet, Rojo, Salvador Novo, Gorostiza.

Conforme Sánchez, esse ir-e-vir, esse discurso bem medido e aparentemente conciliador, se devia a um princípio literário: os contemporáneos não chegaram jamais a apresentar um programa de reivindicações, ou de referências de como proceder literariamente, que por si só os afastasse, radical e absolutamente, de fosse qual fosse o grupo.

Não buscaram nexos entre suas produções, e não pretenderam a "unicidade", desejada por Maples. Mas tampouco se conformaram com as sugestões de González Martínez e companhia, porque queriam uma arte de pesquisa, de especulação, de perguntas, de sugestões; uma arte sem limites (SÁNCHEZ, p. 211).

Para Sánchez, tal dinâmica, característica do dito "grupo sin grupo", é expressiva do momento. Porque enquanto os estridentistas, que se projetaram na década de 1920, produziram um discurso de exaltação de um dado projeto revolucionário, em seus supostos ganhos, e, ao menos no discurso, voltado às massas; os contemporáneos, nos anos 1930, teriam sido representativos de uma crise de consciência, e da perda de credibilidade das falas oficiais, que consideravam e propagavam a ideia de uma Revolução una e necessariamente ampla, popular e democrática (Idem, p. 213).

Aos jovens contemporáneos, logo, convinha romper com o passado, convinha uma Literatura renovada, atual; mas convinha sobretudo criticar o engajamento em projetos fechados e, em mesma medida, o engajamento em projetos fechados de "revolução" e "mexicanidade". Afinal, para eles, o literato mexicano só se consolidaria em âmbito internacional, quando ocupasse o seu lugar na história, seu lugar no mundo, e assumisse o direito de escrever sobre qualquer assunto, e sob todos os riscos.

Segundo Scheridan, reagiram conta um mundo "devastado por uma revolución que há vulnerado a sua clase (...), y há dispersado las generaciones anteriores em diversos exílios”; 
"que há reforzado el centralismo del país, ha conducido al militarismo y a la demagogia nacionalista" (SCHERIDAN, p. 185).

Este era o modo de agir no mundo dos poetas contemporáneos: não-panfletário, estabelecido em parte sob financiamento governamental e gozando de influência e contatos pessoais, mas críticos denunciadores da elaboração de símbolos que, em México, eram considerados, há muito, como verdades inquestionadas. Eis um modo, pois, com o qual Ramos certamente se identificou, e que se faz presente em El perfil, na denúncia de maneiras acostumados de se perceber o mexicano - romanticamente, ou denegrindo; a serviço de tais ou quais interesses políticos, econômicos, nacionais, estrangeiros, pessoais.

Grande parte dos poemas dos contemporâneos dizia respeito à cidade, à vida na cidade, e às perspectivas íntimas do viver moderno. Contudo, como em seu movimento de composição não são tão descritivos, não há em seus versos referências óbvias à urbanidade e ao tempo presente, quanto nos versos estridentistas.

Há uma leitura já bastante clássica dos contemporáneos - a de Paz, em El laberinto de la soledad. É através dela, em geral, que os leitores brasileiros tomam conhecimento acerca da produção desses poetas mexicanos. Através dela, acessamos especialmente trabalhos de Villaurrutia - Nostalgia de la muerte (1938) -, e de Gorostiza - Muerte sin fin (1939), nos quais, conforme Paz, um tema tão caro ao momento revolucionário, a morte, é ponto de partida para reflexões/devaneios; difusos, sublimados. Para Paz, afinal, tanto Villaurrutia como Gorostiza se referiram, então, a um clichê mexicano - a morte, a festa dos mortos através de uma linguagem universal (PAZ, p. 58).

Quanto à prosa dos contemporáneos, foi um tanto incomum. O já citado Genaro Estrada publicou alguns romances que ganharam projeção, mas, como vimos, ele não chegou a ser assim tão próximo aos mais expressivos integrantes do "grupo sin grupo".

Mais interessante seria o trabalho de Ruben Salazar Mallén, Caríatide, escrita em 1932. Escapando um tanto ao internacionalismo e temas urbanos e intimistas, trabalhados por seus colegas, explorou a linguagem do mexicano pobre, da Cidade do México; com foco nos jargões comunistas.

É, entretanto, difícil estabelecer reflexões mais radicais sobre tal novela, porque sobre ela as informações não costumam bater: alguns pesquisadores dizem que foi queimada pelo autor, num triste inverno capitalino, como forma de aquecê-lo; outros investigadores dizem que seu texto equivale a Camaradas, obra publicada no final da década de 1950.

Evodio Escalante considera também a prosa de Villaurrutia; com foco em Dama de corazones, de 1928. Tal romance é narrado em primeira pessoa por Julio, filho de uma família 
chilanga tradicional, que retorna da Europa para sua terra natal. Ele, conta-nos Escalante, se refere ao panorama europeu e à primeira guerra mundial, à decadência de sua família, mas não cita ligações com o Porfiriato ou alude à Revolução - conflitos ou fase institucional (ESCALANTE, p. 100). Diferentemente de Azuela e Guzmán, portanto, ainda que conte uma história que transcorre no México das primeiras décadas do século XX, Villaurrutia não reconstitui qualquer momento, grupo ou fato dito "revolucionário"; narra o momento conforme um olhar alheio a situações e circunstâncias que depois foram tomadas como mais importantes.

Escalante afirma que, dessa maneira, o poeta contemporáneo, na referida novela, absolutamente escapa à abordagem da Revolução. Sugere, na realidade, que ali se compõe, talvez não intencionalmente, talvez sem que se pretenda, mas, sim, se compõe algo como uma "atmosfera", que equivale ao tempo vivido pelo autor, e que é ventilada por percepções pessoais, subjetivas, sensíveis do autor, acerca do México contemporâneo. Escalante, logo, argumenta:

El entramado de acontecimientos al que damos el nombre sintético de Revolución mexicana, no aparece como tal, [sin embargo] tiene en el texto el estatuto de lo innominado, y si se quiere, hasta de lo innombrable". Não se visualiza, portanto, o processo revolucionário com clareza, aqui e ali, mas ele está presente e pode ser capturado todo tempo, invariavelmente, e pesa mais do que as palavras ditas: "se siente la Revolución en la medida misma en que se la evita (ESCALANTE, p. 104).

Ora, esse me parece ser o mesmo tom dos poemas de Nostalgia de la muerte e Muerte sin fin, e também o mesmo procedimento de Ramos, em El perfil, no que diz respeito à Revolução, em sua fase institucionalizada. Eis um segundo ponto, pois, em que perspectivas do ensaísta, em seu livro clássico, remetem a perspectivas que percorriam, variavelmente o "grupo sin grupo": na ora de Ramos não há menções a Obregón ou Calles, mas suas experiências, no México das primeiras décadas dos novecentos, e sobretudo na corrente década de 1930, se fazem perceptíveis a todo tempo nas reflexões estabelecidas sobre o passado, sobre o homem, sobre a cultura nacional, sobre o presente. 


\subsection{Retomando e comparando: sobre Holanda, Ramos, ensaístas e literatos} vanguardistas brasileiros e mexicanos

Considerando as quatro seções anteriores que compõem este Capítulo, podemos observar algumas tendências gerais. Em primeiro lugar, que tanto os ensaístas como os literatos de vanguarda brasileiros e mexicanos formaram conjuntos caracterizados por variações e nuances. E que isso se deu mesmo quando se organizaram em grupos, como no modernismo, do Brasil, e no Ateneo de la Juventud, do México; num como noutro caso, a convivência foi marcada de conflitos.

A partir disso, e voltando uma vez mais às análises dantes esboçadas, pode-se tirar uma segunda conclusão preliminar: esses conjuntos se caracterizaram não tanto por grandes variações de percepção acerca da função social dos intelectuais; mas por distinções na forma como entenderam e estabeleceram relações com o Estado brasileiro e o Estado mexicano, pósrevolucionário em ambos os casos.

Caberia, porém, refletir um pouco mais a respeito, no sentido de avaliar as condições de subordinação, dos pensadores analisados, ao governo Vargas, no Brasil, e aos governos de Obregón, Calles e dos presidentes do Maximato, no México.

De modo geral, conforme Nestor García Canclini, a alta taxa de analfabetismo e escolaridade, no Brasil das primeiras décadas do século XX, impedia uma maior liberdade dos intelectuais em relação ao Estado. "Os escritores não puderam viver da Literatura, tendo que trabalhar como docentes, funcionários públicos, o que criava relações de dependência do desenvolvimento literário com relação à burocracia estatal" (CANCLINI: 68). Já na visão de Carlos Monsiváis, a respeito do México: "en materia cultural, en los veintes, el Estado es simplemente todo" (MONSIVÁIS, p. 723).

Segundo Sergio Micelli, haveria dois tipos de intelectuais ligados ao Estado varguista: os funcionários-escritores, e os escritores funcionários. O que os diferenciava era a vulnerabilidade - tanto no sentido financeiro como no sentido de uma baixa capacidade criativa e reflexiva. Os primeiros, mais cordiais (no sentido buarqueano), se vendiam com maior facilidade, ideologicamente, ao governo - produziam, assim, ao ver do referido pesquisador, "subliteratura”. Os segundos, contudo, distintamente, em seus estudos e escritos tendiam a minimizar (o conseguiam, de alguma maneira) a nota da dependência em relação ao Estado.

Eram, assim, um e outro grupo, opostos: enquanto os primeiros se esforçavam para que os leitores notassem em suas produções a identificação com a ideologia do regime, os 
segundos se esforçavam por serem reconhecidos como talentos individuais, por uma suposta autonomia de pensamento (MICELLI, 1979, passim).

Eu diria que Holanda se enquadra na segunda designação: tanto pela metodologia crítica que buscou aplicar, quanto pelo conceito de "homem cordial" que era justamente uma forma de denunciar o culto à personalidade política e a necessidade de um Estado impessoal, no Brasil; mas também - conforme desenvolvido neste Capítulo - pelas relações que estabeleceu com intelectuais de destaque, em seu tempo.

Na primeira e na terceira seção desta segunda parte foi possível acompanhar a ação de Holanda entre pensadores que desejaram reavaliar o Brasil moderno, calculando possibilidades de transformação, no sentido da conformação de um país mais ordenado, justo, plural e consciente. No que diz respeito à vanguarda, ao romper com a ideia de um modernismo-projeto, Holanda teria estado, logo, mais próximo do modo de pensar de escritores dissidentes dos canônicos Mario e Oswald de Andrade, como Manuel Bandeira e os editores da revista Festa, que desejavam uma Literatura livre no que diz respeito aos temas, e universal no que diz respeito ao alcance.

Ora, se aplicarmos os conceitos de "funcionário escritor" e "escritor funcionário", formulados por Micelli, ao contexto mexicano das décadas de 1920 e 1930, podemos propor também para a Ramos a segunda designação.

$\mathrm{Na}$ segunda e na quarta seções deste Capítulo foi possível observar que Ramos se aproximou de intelectuais mexicanos à época críticos ao regime instituído; tanto no caso dos ensaístas, como no caso dos literatos vanguardistas. Particularmente no que diz respeito à vanguarda, dialogou com os editores da revista Contemporáneos; com o grupo mais jovem desses editores, e que justamente se opunha à ideia de uma Literatura que se fechasse com exclusividade a temáticas mexicanas ou revolucionárias.

Se alguns dos intelectuais brasileiros e mexicanos de princípios dos novecentos agiram com certa margem de liberdade para manifestar seus pontos de vista pessoais, mesmo atuando em cargos estatais, Silviano Santiago insiste em pontuar que, de forma alguma, isso significou confortável condição de livre reflexão.

Para esse crítico, então, o que diferenciava os pensadores e escritores investidos em cargos estatais seria - mais do que certa dependência econômica, ou fragilidade intelectual - a incapacidade ou capacidade de perceber-se como dependentes do sistema; o que, afinal, podia implicar um comportamento mais ou menos corajoso (SANTIAGO, p. 188).

Se nos voltamos os autores abordados seções antes, poderíamos apontar, como exemplar, a coragem de Caio Prado Junior, Graciliano Ramos e Oswald ao se filiarem do 
Partido Comunista, no Brasil; ou que, no México, distintamente, o fato de ser comunista não implicou conflito ante o Estado, ou muito pelo contrário, a partir da chegada de Calles ao poder, como no caso de Lombardo Toledano e Bassóls.

Em se tratando especificamente da "coragem" de Holanda e Ramos, parece-me que serviu como vetor crítico, e se deu de forma dissimulada; tanto um como outro, em seus ensaios mais célebres - Raízes e El perfil - enfrentaram os lugares comuns explorados nos discursos dos estaditas no poder, mas não o fizeram às claras.

Considerando as quatro seções anteriores que compõem este capítulo, podemos, ainda, observar um terceiro aspecto importante a respeito do universo intelectual do qual faziam parte Holanda e Ramos, quando escreveram Raízes e El perfil: pouco a pouco, na década de 1930, se estabelecia o costume de pensadores/escritores brasileiros e mexicanos criticarem os clichês de brasilidade e mexicanidade, então disponíveis, o que contradiz o ponto de vista de críticos tais como Roger Bartra.

É verdade que Bartra escreveu, sobre a vanguarda mexicana com a qual Ramos conviveu, que teria se dedicado a "una reacción contra el nacionalismo"; mas logo em seguida, em sua análise, tal pesquisador pontua que, a despeito disso, eles teriam sido "responsables" pela "codificación e institucionalización del mito del caráter mexicano" (BARTRA, p. 18).

Se nos voltamos à vanguarda do Brasil, lembramos que Sevcenko também abordou os usos que o Estado varguista fez das elaborações, ou da própria causa modernista; entretanto, Sevcenko não responsabiliza nossos poetas e artistas, ou condena sua vasta, plural, complexa, bela e genial produção.

Neste ínterim, eu destacaria, pois, um quarto e último ponto característico do universo intelectual do Brasil e do México, em instantes antes da primeira publicação dos mais célebres ensaios de Holanda e Ramos: o fato de que embora muitos dos livros produzidos naquele momento sejam hoje lidos como metodologicamente equivocados e/ou atrasados, e conceitualmente conservadores, sob o olhar dos homens e mulheres daquele período foram vistos como uma inovação - certamente o caso de Raízes e de El perfil.

Tanto os ensaístas brasileiros e mexicanos abordados nas primeiras seções deste capítulo, quanto os nomes mais expressivos de nossas vanguardas, por exemplo, se voltaram contra correntes abordagens cientificistas, de cunho positivista, focadas em questões raciais, e que redundavam na condenação de nossos países a um destino de caos político, subdesenvolvimento econômico e dependência cultural. 
No que diz respeito à Literatura, há uma sutil distinção. No Brasil, a produção regionalista dialogou com o realismo oitocentista, e renovou conferindo uma dimensão crítico-subjetiva às composições em verso e prosa; não foi, pelas gerações seguintes, considerada representativa de nossa "vanguarda" literária, brasileira, mas apresentou esse ponto fundamental, em comum, com o cânone modernista. Quanto ao modernismo, em São Paulo, trabalhou um mesmo olhar subjetivo sobre o real presente, com ênfase no universo urbano.

No México, a literatura realista do século XIX se desdobrou na chamada Novela de la Revolución, que abordava a realidade do campo e das cidades sem grandes ousadias estilísticas ou teóricas. Poderíamos dizer, assim, que Azuela se aproximava, em sua escrita, de Euclides da Cunha, e não tanto de Lins do Rego ou Graça Aranha; e Guzmán a Lima Barreto, e não tanto Oswald com seu Memórias sentimentais de João Miramar (1924).

Depois, já especificamente nos poemas e romances rotulados de vanguarda - tanto elaborados por estridentistas como por contemporáneos - nota-se uma intenção equivalente à brasileira, de abordar poeticamente, criticamente, subjetivamente, a realidade vivenciada. Mas com a nota dissonante de que os estridentistas trabalharam mais elementos de um supostoreal-urbano em poesias, de um suposto-real-rural em romances, e os contemporáneos o fizeram de forma bastante difusa, focando universos psicológicos, individuais, introspectivos, do sonho e da morte - com as exceções bem marcadas dos Poemas proletários, de Salvador Novo, e do romance Dama de corazones, de Xavier Villaurrutia.

Soma-se que, tão próximos, em certa medida, do realismo a que foram críticos, os vanguardistas brasileiros e mexicanos se propuseram como avessos ao romantismo escapista. E que, se - hora ou outra - compartilharam com a literatura romântica o interesse pelo nacional, e um certo tom entristecido, ou íntimo-pessoal, no discurso se apresentaram como inimigos, o que certamente tende a implicar distinções mais do que triviais, fáticas. De minha parte, apostaria que as principais diferenças entre Romantismo e Vanguarda, no Brasil e no México estariam, para além dos temas e métodos, nos sentidos que conferiram à função social dos intelectuais: os primeiros mais próximos e a serviço do Estado em formação; os segundos mais críticos das propostas de regime apresentadas e experimentadas, desde então.

Daí, devemo-nos voltar, por fim, para um primeiro ponto, levantado no início desta seção: a proximidade de Holanda e Ramos à literatura, não se dá num sentido - simplista, esquemático, redutor - de Literatura como uma elaboração caracterizada pelo desinteresse pelo real, por escapismo, ou pela mera elaboração retórica e utopista. 
Entre ensaístas interessados em abordagens sócio-psicológicas e expoentes da vanguarda, eles exerceram a crítica da Literatura e da cultura - da escrita, das identidades, dos símbolos - buscando estruturar seus modos de perceber o pensamento e a existência material, no Brasil e no México, num passado que se desenrola num presente vivo. Tomaram, assim, tanto a Sociologia a Psicologia quanto as reflexões vanguardistas como importantes referências de como questionar o mundo, o homem, as ideias, o agir do homem no mundo, e especificamente na América Latina. 


\section{CAPÍtULO 3:}

\section{“Revolução" em Raízes, El perfil e em outros textos clássicos}

\subsection{Considerações iniciais}

É amplo e complexo o debate sobre a dimensão "revolucionária" do Brasil e do México das primeiras décadas dos novecentos. Em suas especificidades nacionais inclui vertentes interpretativas variadas, que focam aspectos distintos; e que, tanto no caso brasileiro como no caso mexicano, pontuam o alcance relativo das alterações promovidas através ou por movimentos que então se chamaram "revolucionários".

No caso do Brasil, entre os intérpretes da Revolução de 1930 tivemos como bastante característica, na década de 1960, a tese da "Revolução burguesa", na qual se destacaram os nomes de Nelson Werneck Sodré, Virgínio Santa Rosa e Hélio Jaguaribe. Sodré, por exemplo, sugeriu que a partir da década de 1930 o Estado brasileiro se teria imbuído da "função histórica" assumida pela burguesia de países como a França, de promover a transição de uma lógica feudal para uma lógica capitalista - nas instituições, nas leis, na economia (SODRÉ, 1967).

Dessa perspectiva, anos mais tarde outros autores passaram a propor que o ordenamento político estruturado a partir de 1930 se teria dado sob iniciativa de um grupo que se aproveitava do momento de crise dos poderes instituídos, de uma ambígua burguesia cafeeira, de um "vazio de poder". Para Francisco Weffort, esse grupo seria caracteristicamente, ainda, composto por elementos da oligarquia rural, daí a improcedência do termo "Revolução burguesa" (WEFFORT, 1989). Para Boris Fausto, esse grupo, um tanto heterogêneo, teria estabelecido, assim, um "pacto intra-elites" (FAUSTO, 1969).

Luís Werneck Viana comparou os processos históricos desdobrados no Brasil daquele período com os processos históricos desdobrados na Europa Central, no final do século XIX, e observou, num caso como n'outro, "revoluções pelo alto"; vindo a classificar a "Revolução de 1930" como "via prussiana para a modernização" (VIANA, 1976: 45).

Num sentido semelhante, Angela de Castro Gomes apresentou o Estado que se institucionalizou entre os anos 1930 e 1937, pela força personalista de Getulio Vargas, como "desordenador" das demandas civis, dos agrupamentos politizados de trabalhadores, como responsável pelo desmonte de classes (GOMES, 1996). E Luís Werneck Viana falou em "Revolução passiva" (VIANA, 1976). 
Ora, todos esses mencionados estudiosos partem de noções de "revolução" estrangeiras, sobretudo a Francesa, no século XVIII, para elaborar seus vereditos sobre o alcance revolucionário das mobilizações que marcaram o cenário brasileiro, nas primeiras décadas de 1930.

A partir da década de 1960, buscando bem entender o sentido revolucionário dos movimentos sociais desenrolados no México em princípios do século $\mathrm{XX}$, muitos pesquisadores estabeleceram também comparações entre aquela dinâmica mexicana e fatos históricos decorridos em outras configurações de espaço-tempo. Diferentemente do que ocorreu a respeito do Brasil, porém, compararam a dita Revolução Mexicana, que teria início em 1910, não apenas com a Revolução Francesa de 1789, ou com a formação da nacionalidade alemã, mas também com a Revolução Russa de 1917.

Entretanto, me pergunto: tais comparações, que em geral vêm servir como base para que se considere nossas "revoluções", na América Latina, como nada mais que falácias, são justas? Conforme Lorenzo Meyer, não. Esse pesquisador argumenta que os territórios francês, prussiano e russo correspondem a realidades bastante distintas das nossas, latinoamericanas; e que as revoluções ali vivenciadas foram motivadas por fatores bem distanciados daqueles que foram considerados essenciais, por exemplo, pelos revolucionários mexicanos (MEYER, 1987).

Isso me faz pensar que, mais interessante do que comparar nossa realidade e a europeia, é comparar as nossas, diversas, internas ao continente latino-americano; me faz pensar na relevância dos propósitos da presente Tese.

E fato é, afinal, que mais de um século depois de os franceses irem às ruas falando em "revolução", e alguns anos antes de os russos consolidarem um Estado Revolucionário, o México tratou de resgatar o vocábulo, em campos de batalha abertos, na imprensa, e também em textos bem articulados, como El perfil.

De minha parte, acredito que, tão importante quando considerar as avaliações feitas por historiadores mais recentes, a respeito do alcance das medidas então propostas, é considerar como os intelectuais se posicionarem a respeito naquele exato momento. Contudo, como aponta Carlos Guilherme Mota, a Revolução de 1930 tardou a ser abordada sistematicamente pela crítica; "pouquíssimo se escrevera [sobre ela] até a década de 1960", sugere tal historiador (MOTA, 2008b, p. 25).

A análise desse silêncio, notável na época em que Holanda escreve Raízes, pode, porém, nos render importantes considerações. Eu sugeriria, a princípio, duas. Primeiro, que muitos pensadores à época já insinuavam considerar que a tal "Revolução", não correspondia 
a um feito tão significativo e transformadora, quanto pregavam as autoridades. Depois, que houve, então, quem ousasse chamar "revolucionários" conjuntos de fatos e fatores diversos.

Raízes é, a meu ver, uma obra que encaixa nesses dois casos: por um lado, ali Holanda se absteve completamente de abordar e valorar as alterações políticas propostas e implementadas desde 1930; e, por outro, apresentou como "revolucionárias" movimentações bem anteriores, sinalizando que a inovação real, radical, se havia, não vinha de agora.

Quando pensamos o processo revolucionário mexicano, hoje, devemos necessariamente nos referir a autores mais recentes, mas que são também considerados canônicos: os mexicanos Hector Aguilar Camín, Álvaro Matute, Lorenzo Meyer, Enrique Krauze; o francês Jean Meyer, o austríaco Friedrich Katz, e o norte-americano John Womack. Esse grupo, cujos estudos ganharam destaque a partir da década de 1960, foi denominado "revisionista", porque se dedicou à reavaliação das mais tradicionais versões sobre a história da Revolução Mexicana.

Acontece que alguns estudiosos dos processos que marcaram o México dos primeiros decênios dos novecentos se têm dito interessados em promover uma revisão crítica da própria abordagem dos "revisionistas"; a exemplo dos britânicos Alan Knigth e David M. Bailey.

Knight, por exemplo, resgatou investigações produzidas por autores das décadas de 1920 e 1930, para propor que naquele momento foram formuladas visões acerca da Revolução Mexicana que, de alguma maneira, devem ser consideradas válidas e bem medidas (KNIGHT, 1999). E Bailey, afinal, argumentou que a crítica acerca dos significados conferidos ao processo dito "revolucionário" teria sido - diferentemente do que ocorre no caso brasileiro - bastante característica do processo revolucionário desde seus primeiros anos; de maneira que a própria denominação de "revisionismo" pode ser questionada, se igualmente historicizada (BAILEY, 1979).

Num mesmo diapasão, em texto sobre o centenário de Revolução Mexicana, celebrado em 2010, o ensaísta mexicano recentemente desaparecido, Carlos Fuentes, classificou a Revolução Mexicana: "revolución crítica y criticada" (FUENTES, 2010).

Ora, a análise cuidadosa de textos produzidos nas primeiras décadas dos novecentos, no México, me parece confirmar o argumento de Bailey; confirmar que desde aquele momento críticos se interessaram não apenas por criar mas também refletir sobre os sentidos conferidos ao que se convencionou chamar "Revolução Mexicana" - e Ramos esteve entre eles. Por fim, eu diria que pela leitura dessas fontes pode-se, ainda, considerar a procedência da hipótese de Knight, na medida em que elas sugerem diversas versões, por vezes 
desencontradas, e associadas a interesses distintos, difíceis de enquadrar em qualquer reta classificação, mas bem estruturadas, interessantes, válidas. 


\subsection{O tema da "revolução" em Raízes}

Sugeri em outros momentos desta Tese que não é simples definir qual era, afinal, o objetivo central de Holanda em Raízes do Brasil. O fato de ser um ensaio e não um tratado ou um trabalho monográfico, o fato de ter sido reescrito edição após edição, e de ter sido lido, relido e um sem-número de vezes ressignificado torna sua leitura uma tarefa difícil; e confere às apreciações mais triviais a respeito, um caráter problemático.

Estou convencida, contudo, de que, se não era o objetivo central, ao menos era um dos mais importantes, para Holanda, nesse ensaio, pensar a possibilidade de uma revolução no Brasil - o que isso significava, o que isso deveria implicar. Foi o que o próprio autor, aliás, declarou, em entrevista concedida em 1976: "A ideia básica [de Raízes do Brasil] era a de que nunca houve democracia no Brasil, e de que necessitávamos de uma revolução" (Apud. MARTINS, 2009, p. 85).

A bem da verdade, na transição da década de 1920 à década de 1930, Holanda já havia publicado artigos nos quais questionava os sentidos então atribuídos à palavra "revolução". Aí então ele demonstrava compreender que "revolução" como todo tipo de brusca alteração nos gabinetes governamentais de um país, ou nas cúpulas de governo de um Estado.

Da Alemanha, Holanda ia, porém, percebendo que tal termo perdia a conotação pejorativa, e que se generalizava o entendimento de "revolução" como um justo recurso, disponível para acesso ao poder, por determinados grupos que, dentro dos parâmetros legais, não logravam nem poderiam lograr atuar politicamente com notável repercussão. Com um detalhe importante: a denominação de "revolucionárias" apenas caberia a alterações políticoadministrativas ou legais promovidas por tais setores se representavam importantes forças de transformação no âmbito do pensamento e do comportamento (Idem, p. 284).

No texto propriamente de Raízes, Holanda também abordara o termo "revolução" como passível de ser compreendido e empregado de distintas formas.

Num primeiro momento, se referiu ao trabalho do psicólogo alemão radicado no Chile desde 1903, Wilhelm Mann, Volk und kultur Lateinamerikas (em tradução livre, "O homem e a cultura latinoamericanos", de 1927). E pontuou que, conforme Mann, era necessário advertir “contra o emprego, a seu ver, abusivo, da palavra 'revolução', quando sucede um general sulamericano, à frente de sua tropa, pôr abaixo o presidente e nomear-se - por quanto tempo? para o seu lugar”. Pontuou que, conforme Mann, “esses movimentos constituíam muitas vezes pormenores insistentemente reiterados do processo geral - e em verdade revolucionário - da 
transformação dos territórios coloniais em sociedades cultas modernas" (Apud. HOLANDA, 1999, p. 208).

Num segundo momento de Raízes, Holanda considerava, ainda, que, segundo naturalista norte-americano, Herbert Smith, que esteve no Brasil em 1870, a América do Sul estava farta de "revoluções horizontais", "remoinho de contendas políticas, que servem para atropelar algumas centenas ou milhares de pessoas menos afortunadas". E que se fazia urgente "uma boa e honesta revolução, (...) uma revolução vertical e que trouxesse à tona elementos mais vigorosos, destruindo para sempre os velhos e incapazes" (Apud. HOLANDA, 1999: 181).

Note que, em ambos os casos, Holanda aludia, negativamente, a algo como "falsas revoluções" - "revoluções de superfície", "revoluções horizontais". E, em ambos os casos, propunha como enganadoras essas agitações políticas que se diziam revolucionárias, porque utilizadas discursivamente, simbolicamente, por determinados líderes ou grupos, a despeito dos interesses de uma massa ansiosa por mudanças. Em ambos os casos, ademais, falava em "a boa e honesta revolução", "revolução vertical" como, como um movimento que implicaria transformação profunda. Em ambos os casos, considerava como revolucionário o acesso ao novo: o rompimento com a condição colonial, o ingresso na modernidade, a destruição de tudo que era "velho", “incapaz”, improdutivo, infértil.

Em outros trechos de Raízes ele retomava tal classificação. Num viés negativo, tratou, então, de movimentos ditos "revolucionários" que equivaliam a "convulsões de superfície", “transformações exteriores", "agitações", “desvios na trajetória da vida política legal do Estado", "revoluções palacianas", "fato que se registra em um instante preciso", "convulsões catastróficas". E, num viés, positivo, movimentações "lentas", "demoradas", "sem grande alarme”, mas “seguras", “concentradas”, “irrevogáveis” (HOLANDA, 1999, p. 171, 172, 180. 181).

Para Holanda, afinal, o período de colonização teria a nós legado um modo civilizacional a ser superado; e que, mais do que qualquer alteração formal em nossos governos e em nossa Constituição, a superação desse modo, dessa cultura, é que deveria ser considerada a "Nossa Revolução" - título do último capítulo da obra.

Em outras sequencias desse livro, ele pontuou que uma verdadeira e efetiva Revolução Nacional se teria iniciado no Brasil "pelo menos há três quartos de século" antes daqueles corridos anos 1930 (HOLANDA, 1999, p. 171).

Ele observava, porém, em meio a essa radical e processual transformação, uma fase mais aguda: o ano de 1988, sobre o qual propôs: "Se a data da Abolição marca no Brasil o fim 
do predomínio agrário, o quadro político instituído no ano seguinte [o Republicanismo, proclamado em 1889] quer responder à conveniência de uma forma adequada à nova composição social" (Idem, p. 171). Em outras palavras, embora a transformação viesse de longe, ela necessitava da supressão de certos obstáculos, que a Abolição condenava à deterioração e apagamento (Idem, p. 172).

Ainda assim, ao ver de Holanda, havia muito por fazer. Aliás, essa percepção é tão forte e reiterada em Raízes chegamos a desconfiar da crença do autor na possibilidade de um Brasil mais justo, honesto, organizado politicamente; novo, revolucionado.

Consideremos que ideia de revolução processual incluía, ainda, em Raízes, duas distensões importantes, para as quais devemos estar atentos: a ideia de que o processo revolucionário no Brasil só era revolucionário na medida em que atendia a especificidades locais (na medida em que se fazia enquanto revolução realmente "nossa"), e a ideia de que a "Nossa Revolução" se caracterizava não apenas por mudanças, mas por continuidades.

Constitui isso uma ambiguidade? Aparentemente, sim, afinal: Como pode uma "revolução" ter de implicar inovação, e rompimento com hábitos sedimentados, e, ao mesmo tempo, levar em consideração o que é próprio e local, se dar conforme uma tradição?

Ettore Finazzi-Agrò, professor da Università di Roma, Holanda, afinal, não acreditava na possibilidade de nosso país concluir uma rota revolucionária. Para ele, a escolha dos títulos dos dois últimos capítulos de Raízes correspondia a uma ironia do ensaísta: "não existem 'novos tempos' e tampouco existe uma 'revolução' que possa ser 'nossa'” (FINAZZI-AGRÒ, p. 148).

Mas Candido, diferentemente, fala em "contradições não resolvidas", "impasses", "oscilações", e assim denota que, a seu ver, para Holanda, desenhava-se no Brasil uma situação revolucionária, sim, ainda que, ou justamente por, bastante peculiar (CANDIDO, 1999, p. 18-19).

Segundo Arnoni Prado, Holanda conceber, em Raízes, a "revolução" brasileira como um movimento de transformação significativa, mas progressiva, continuada. No Brasil contemporâneo, em que Holanda vivia, haveria algo de fato revolucionário, ao ver do ensaísta, embora ainda pouco claro; no Brasil de então, a revolução estaria "ainda lutando por vir à luz” (Apud. PRADO, 2006, p. 306).

Bom lembrar que, Holanda sugere em Raízes serem inúteis os esforços no sentido de "transformar de um mortal golpe, e segundo preceitos de antemão formulados, os valores longamente estabelecidos" (HOLANDA, 1999, p. 180). 
A “nossa revolução", ao ver de Holanda, em Raízes, seria, conforme Piva: "o novo sob o guia da tradição", do que nos era próprio (PIVA, 2000, p. 182).

Para Mariza Veloso e Angélica Madeira, “aquela revolução era interpretada, por Sergio, como uma brotação, um ajuste moderno, que recolhe das raízes a seiva antiga" (VELOSO; MADEIRA, p. 167).

De acordo com Berenice Cavalcanti, quando Holanda escreve Raízes, naquela exata conjuntura, "nosso atraso [passava a] ser pensado como expressão de uma temporalidade própria"; de maneira que esse autor, essa obra, deve ser considerada como exemplar de uma nova "busca de nossa[s] singularidade[s] no concerto das nações" (CAVALCANTI, 2009, p. 139).

É curioso notar, então, que Mota, embora seja largamente considerado como um dos principais críticos à dos ensaios produzidos nos anos 1930, dentre os quais Raízes, em seus artigos da década de 1960, reunidos em A ideia de revolução no Brasil, tenha apresentado uma concepção de "revolução" muito próxima à do jovem Holanda. Primeiro, pelas balizas temporais que elege: para Mota o "longo século XIX, (...) marcado fundamente pela mentalidade imperial bragantina se encerra em 1889" (MOTA, 2008b: 264-265). Depois, por considerar que a independência teria correspondido a um primeiro impulso "revolucionário", por ter sido "o ponto de partida para a construção de um sistema ideológico consistente, tendo como pilar a ideia de nação, alimentada pela elaboração contínua de uma História nacional e, portanto, de uma historiografia que a cultivasse" - e, eu diria, de um autêntico "pensamento político brasileiro" (MOTA, 2008b, p. 389). 


\subsection{O tema da "revolução" em $E l$ perfil}

Desde já eu diria que, se comparado a Holanda, em Raízes, Ramos em El perfil empregou o termo "revolução" de uma forma aparentemente um tanto despreocupada; o fez simplesmente como era comum fazer-se, então, em seu país, sem definir, às claras, possíveis implicações e pluralidades de significados da palavra.

Não é curioso que tal diferença se estabeleça, entre o autor mexicano e o autor brasileiro estudados nesta Tese? Ramos foi posteriormente reverenciado por suas proposições filosóficas, e Holanda por suas proposições históricas e sociológicas... Não seria esperado que El perfil apresentasse discussões acerca dos usos dos conceitos ali mais importantes? E não é também curioso que Ramos, que tanto se interessou pela fala do mexicano, tenha se descuidado, e empregado um termo, assim, tão repisado, sem explicitar, ao leitor, seus possíveis sentidos?

A mim me parece, entretanto, que tal fato não implica menor interesse de Ramos pelo tema da revolução; significa tão somente que, em seu livro mais famoso, o interesse pela "revolução", como conceito, não foi estruturado de forma clara e sistemática. Cabe a nós, investigadores de hoje, logo, avaliar com cuidado as austeras referências explícitas de $E l$ perfil ao problema; porque elas podem embutir dimensões de crítica e entendimento muito ricas, acerca da realidade e do pensamento da época, enquanto "revolucionários".

Aqui convém começar pontuando que, no texto de seu ensaio mais célebre, Ramos denominou "revolução" um instante determinado do passado recente de seu país, que ganhara repercussão não apenas em território nacional, mas na imprensa de todo o mundo, e que até hoje vem sendo vastamente investigado, revisto, recriado.

Nisso, mais uma vez, se afastava de Holanda, que não fez, em Raízes, sequer uma menção explícita à chamada "Revolução de 1930".

Decerto tampouco Ramos fez um inventário dos fatos que envolveram a dita "Revolução Mexicana"; como pontuei capítulos antes, ele não trabalhou, em El perfil, com a tradicional história dos grandes acontecimentos e grandes homens. Porém, como cidadão mexicano do início do século XX engajado na busca por compreender o México moderno a partir de um viés histórico, cultural, psicológico e social, manteve a problemática do fato"revolução" como referencial importante.

Em segundo lugar, eu diria que, no famoso livro de Ramos, "revolução" aparece como um conjunto de mobilizações de setores sociais diversos, que pegaram em armas por desejarem tomar o poder, e/ou alterar a dinâmica institucional administrativa nacional. 
Nisso nos faz lembrar a definição que Holanda apresentou, em Raízes, para "revolução horizontal": na seção, anterior vimos que, conforme o ensaísta brasileiro, partindo de Mann e Smith, a política, na América Latina como um todo, se caracterizava por combates armados que frequentemente desembocavam em alterações no corpo estatal, e nada mais do que isso.

Convém fazer notar, logo, que na atualidade é costume, entre os governos e historiadores, aludir àqueles desdobramentos políticos, no México dos anos 1910, usando maiúsculas para as letras iniciais. Em nossas análises, escrevemos, em geral, "Revolução Mexicana", como forma de sublinhar a singular importância deles. Do início ao fim de $E l$ perfil, contudo, Ramos escreveu a palavra toda em letras minúsculas, denotando, talvez, a sensação de que, a despeito de sua importância, aquela revolução lhe parecia apenas mais uma, entre tantas.

E é verdade que, ali mesmo, em El perfil, en passant Ramos denominou também "revolução" um conjunto de fatores, situações e práticas do México da segunda metade do século XIX: falou, pois, em "revolución de la Reforma" (RAMOS, p. 131). Eis aqui, aos olhos dos historiadores de hoje, uma exótica e aparentemente contraditória maneira de rotular um momento histórico: tal designação inclui, afinal, de uma só vez, referência à transformação profunda, pelo termo "revolução", e às mudanças menos estruturais, pelo termo "reforma". Senão, vejamos o que podemos concluir a respeito.

Ao que me parece, Ramos designava "Reforma" - palavra iniciada por letra maiúscula - um instante da história nacional mexicana à sua época já icônico. Mas um instante no qual se acreditava terem ocorrido significativas alterações institucionais, que, por isso, a seu ver, lembraria momentos recentes da história mexicana, ditos "revolucionários". Haveria, além disso, outro ponto que aproximaria a "Reforma" dos 1800 da denominada "revolução" dos 1900: o fato de terem ocorrido por meio de intensa "agitação".

Note que esse momento teria sido tão importante na História nacional mexicana, para Ramos, quanto a Abolição e a instauração da República, para a História brasileira, ao ver de Holanda, como aludi anteriormente. Em ambos os casos, sinaliza-se que alguns passos, institucionais, importantes no sentido da transformação já vinham sendo dados.

Entretanto, note bem: conforme na narrativa de Ramos eram "políticos" que haviam operado, institucionalmente, a "Reforma" do século XIX; distintamente, a "revolución", pura e simples, do século XX, correspondera a um "estalar", uma "tragédia", uma "guerra" (RAMOS, p. 131).

Devido ao quadro de desordem, poderíamos dizer - lê-se em El perfil - que as recentes alterações "revolucionárias" corresponderiam a anseios pouco fáceis de se saber, 
afinal, quais eram. Elas haviam ocorrido, assim, em uma marcante dimensão de aleatoriedade. Daí Ramos defini-las como "un remolino circulante que trastornaba cuanto encontraba a su paso" (Idem, p. 136).

Ora, essa ênfase no caráter aleatório da "revolução" não é explicitado nas definições de Holanda. Talvez ele seja abordado, como tema, de alguma maneira, em outro tom: na referência de Holanda ao espontâneo, não-osquestrado, que elogia. Em Ramos, porém, o aleatório aparecia como essencial; lhe incomoda profundamente.

Para Ramos, ainda que aleatória e incômoda, "revolução", contudo, deveria implicar e implicava, como para Holanda, profundas transformações. É ilustrativo disso, por exemplo, o fato de que esses dois ensaístas quando empregaram, pela primeira vez, em seus clássicos, a palavra "revolução"/"revolución", o fizeram igualmente num dos capítulos finais, em que suas reflexões se abriam para considerar o "novo", na história nacional.

Em terceiro lugar, a partir disso eu diria que Ramos é mais evidente e pontual do que Holanda na abordagem das inovações "revolucionárias". E acrescentaria que, a meu ver, era de se esperar, se vivia ele em um país que havia passado por tantas perturbações sociopolíticas, com tendências radicais, a sensação de novidade a toda prova. Por outro lado, era de se esperar, também, que Holanda, sob um regime que começara seu curso ignorando/impedindo a participação das massas, apresentasse como mais difusas as alterações sociais, políticas, culturais.

O leitor pode se perguntar: Qual a relação exata entre mobilização das massas e perspectiva de novo? Evidente que não se trata de uma relação necessária, mas fato é, e fato lógico, que em Ramos a perspectiva da presença dos mais diversos grupos sociais no jogo político repercutiu no aludido desconforto, receio e certeza da distensão do horizonte de possibilidades futuras num ângulo mais obtuso - nos dois sentidos da palavra "obtuso".

Importante lembrar, nesse momento, como quarto ponto importante, que, embora os aborde, Ramos não define como "revolucionários" os governos que se estabeleceram a partir das convulsões de 1910. Sim, ele denominou "revolução" tão somente o complexo de agitações armadas, e não incluiu nessa denominação todo o regime que vigorou depois e que se auto-proclamou "revolucionário". É possível que ele assim o considerasse ou denominasse - como o fez no caso da Reforma; entretanto, o fato é que isso não se deu nas páginas de em El perfil.

A bem da verdade, eu acrescentaria que a escrita de Ramos nos indica que o autor não considerava a atuação desses governos, institucionalizados, como tão determinantes no curso das transformações mais significativas, no México de então. E eu diria que, em seu ensaio, 
por vezes, algumas das transformações que ele parece considerar como fundamentalmente relevantes aparecem datadas de antes do emblemático 1910.

Afinal, ao que tudo indica, segundo o ensaísta mexicano, lembrando o que propus a respeito da interpretação de Holanda, para que uma nação efetivamente nova surgisse, eram necessárias mais do que mudanças político-institucionais; eram necessárias mudanças culturais, e elas ocorriam, para Ramos e para Holanda, a despeito dos direcionamentos político-administrativos e constitucionais.

Afastando-se mais uma vez de Holanda, contudo, Ramos considerou, em El perfil, como exemplar o papel incisivo e pontual dos pensadores mexicanos que, em seu entendimento, independentemente do Estado instituído, ajudaram a "interrumpir la calma soñolienta en el mundo intelectual de México" (RAMOS, p. 136).

Considerou, também, a seguinte mudança, mais ampla, na "psicologia nacional":

En el curso del segundo decénio de este siglo se produce un cambio de actitud del mexicano hacia el mundo. Comienza éste a interesarse por su propia vida y el ambiente inmediato que le rodea. Descubre en su país valores que antes no había visto, y en ese mismo instante empieza a disminuir su aprecio por Europa (Idem, p. 140).

Um quinto aspecto importante, da reflexão de Ramos: esse autor, a respeito do México, tal como Holanda, a respeito do Brasil, percebia que o processo de transformação não estava acabado; longe disso, faltava muito para que se pudesse falar em um país novo, e autêntico. Identificado o "eu", identificados os "problemas" e as "qualidades" do eu mexicano, era necessário ainda que se processassem mudanças fundamentais, no modo de ser do mexicano.

Do ocaso revolucionário resultara, a seu ver, um México que lembrava muito o México de anos antes; e um mexicano que se caracterizaria por uma série de comportamentos idênticos ao do mexicano de outrora. Ramos, em El perfil, lamentou, todo o momento, que mesmo decorridos tantos tempo, e gasto tantos esforços, em plena década de 1930 seu país seguisse se caracterizando pela injustiça social, desordem política, violência cotidiana, ignorância.

Já é clássica a abordagem que Paz, em El laberinto, faz do conceito de "revolução", no México. Reforcemos, de tal texto, pois, que ali Paz também apresenta a ideia da revolução como uma movimentação confusa, e do momento como caracterizado pela percepção, por parte do mexicano, de que ele, afinal, existia (PAZ, 2006).

Segundo a interpretação de Paz, além disso, a revolução mexicana, aqueles embates violentos entre grupos armados, teria sido percebida por seus contemporâneos (por exemplo, 
pelo general radical Emiliano Zapata) como um movimento que apontava igualmente para o futuro e para o passado. Ao ver de Paz, os revolucionários desejavam não apenas um mundo absolutamente novo, mas a restauração de uma "idade mítica" (PAZ, p. 74).

Entretanto, me parece que, embora Ramos, como pontuei acima, assinalasse uma série de continuidades na história nacional mexicana recente, não pode ser enquadrado nesse segundo ponto da interpretação de Paz, acerca da Revolução Mexicana. Sim, porque Ramos, mesmo observando muito de passado do presente, compreendeu o devir histórico como irreversível; sentiu-se desconfortável com a insistente presença de determinados comportamentos, no México moderno; não tendeu a ser saudosista, romântico.

Como um sexto fundamental nó do argumento de Ramos eu proporia, assim, o fato de que, a seu ver, a percepção do mexicano, no momento revolucionário, no que diz respeito à própria existência não implicava volta ao período pré-hispânico; implicava a possibilidade de novo-mais-que-novo, livre e singular.

Em outras palavras, conforme Ramos, "[comenzaria] entonces una segunda independéncia, tal vez más transcendente que la primera, porque [dejaría] al espíritu en libertad para la conquista de su destino" (RAMOS, p. 150).

Ramos fez, ademais, em El perfil, uma clara defesa das especificidades do processo revolucionário local, respondendo aos juízes europeus que era possível que, como estrangeiros - por partirem de um repertório de valores alheio ao nosso -, não compreendessem o sentido das guerras promovidas na América Latina. Ele lembrava, nesse momento, que muitas de nossas guerras chegariam ao fim sem que aparentemente nenhum dos lados - por vezes, como no caso da Revolução Mexicana, muito mais do que dois lados houvesse alcançado vantagem alguma. Porém, afirmava que isso não correspondia a um problema, senão à consequência de uma especificidade latinoamericana, que deveria ser considerada positiva: a passionalidade, o modo de agir apaixonado (Idem, p. 162-163).

Ora, a percepção da história recente como uma libertação, como uma independência, como uma forma de o homem local se apresentar como autêntico, no concerto internacional, é notável também no texto de Raízes.

A título de conclusão, eu diria que a modernidade mexicana, na interpretação de Ramos, deve ser compreendida como, em suas especificidades, semelhante à modernidade brasileira, na interpretação de Holanda, porque em ambos os casos os problemas mais relevantes e dignos de nota se dariam como tensão dialética: entre o discurso/a forma/o ordenamento e a prática; o novo e o velho; o nosso e o alheio; o próprio e o problemático. 
A partir disso eu acrescentaria, ainda, que não se sustenta a tese de que a leitura de $E l$ perfil endossa a ideia de uma "revolução mítica", no México; tal como não se sustenta a tese de que Raízes serviu comodamente ao cardápio ideológico do regime político em vigor, pósRevolução de 1930. Em seus clássicos ensaios, Ramos e Holanda contribuíram, afinal, menos para a elaboração de símbolos, que para a crítica; menos para a normatização das perspectivas sobre o presente, que para a denúncia as ambiguidades e conflitos.

Por fundamentais, esses quatro nós serão retomados, por diversas vezes, e em diversos prismas, nos próximos capítulos e também, ou sobretudo, no Quarto e último capítulo desta Tese.

Mais algumas especulações sobre o que parece implícito, em $E l$ perfil, da visão de Ramos acerca da Revolução Mexicana

Uma das principais críticas à historiografia dita "tradicional", dedicada ao tema da Revolução Mexicana, recai sobre as versões que a apresentam como um acontecimento histórico que corresponde a um "bloco" mais ou menos homogêneo - das declarações contra o ditador Porfírio Díaz, publicadas por Francisco Madero, em 1910, até ou além da presidência de Lázaro Cárdenas, na década de 1930.

Os revisionistas mexicanos defenderam que, diferentemente, todo esse percurso foi marcado por momentos cujos propósitos, realizações e principais líderes diferem. Defenderam a noção de "processo revolucionário", marcado por variações no tempo e no espaço.

De minha parte, mais do que um encadeamento de intenções e práticas confusas, por vezes ambíguas, a Revolução Mexicana corresponde a um encadeamento discursivo. Assim, em minha abordagem, as mais diferentes etapas remetem umas às outras; as posteriores selecionando aspectos e nós das anteriores, como relevantes ou irrelevantes, sob o propósito de legitimação de determinados interesses e poderes. Assim, não considero a Revolução, no México, como simplesmente um fato ou um conjunto de fatos articulados, ou desarticulados; e sim como uma elaboração simbólica, baseada em registros sobre fatos separados ou conectados, aos quais se atribuem diversos significados, num decorrer do tempo.

No mais, ainda que muitos dos ditos revisionistas critiquem a tradicional percepção da Revolução Mexicana como um bloco homogêneo de acontecimentos, podemos dizer que, já no momento em que Ramos escrevia El perfil, ela foi pensada como composta por diferentes 
temporalidades. Houve, então, uma considerável diversidade de entendimentos a respeito da melhor maneira de se perceber as alterações processadas a partir de 1910.

Observemos, como referência, a abordagem de Plutarco Elías Calles, que foi conhecido como el Jefe Máximo: presidente do México entre os anos de 1924 e 1929, mas que manteve viva importância política até 1934, num intervalo denominado Maximato.

Para ele, a fase armada da "Revolução" havia chegado ao fim no ano de 1917, quando, no governo de Venustiano Carranza, foi promulgada uma nova Constituição, e foram garantidas bases legais a partir das quais os presidentes mexicanos deveriam proceder. A partir de 1929, com o fim de seu próprio mandato oficial e a morte do recém-reeleito Álvaro Obregón, Calles falou sobre a necessidade de se operar nova ruptura: defendeu, em seus discursos, o verdadeiro fim do caudillismo e o efetivo início de uma etapa "institucional" (GARCILADIEGO DANTAN, p. 189).

A princípio, faz-se mister retomar que Ramos, em El perfil, designa "revolução" apenas a primeira dessas etapas pontuadas por Calles. Entretanto, fato é que, nas páginas do dito ensaio, ele não ignorou o que ocorreu, nos anos seguintes, na política institucional de seu país. Uma leitura cuidadosa do livro nos sugere, então, que o referido ensaísta, ainda que não os rotulasse explicitamente "revolucionários", considerou, em seu texto, os desdobramentos desenhados pelo discurso do Jefe Maximo.

Senão, vejamos: Ramos se refere a determinados fatos, que ele julga pontuais nas experiências históricas recentes do México; e esses fatos nos remetem ao seguinte movimento: caos "revolucionário"; seguido da criação de um Estado legal, para o qual trabalharam intelectuais com uma dada intenção "nacional"; e, por fim, uma volta renovada a um discurso sobre a importância de ordem política, objetiva.

Duas observações finais, se fazem necessárias nesta seção: primeiramente, que embora Calles tenha considerado a atuação de Obregón na presidência como uma etapa anterior, associável à de Carranza, seu próprio governo foi em muitos sentidos associado ao de Obregón; ambos sendo sonorenses, diz-se, teriam agido conforme um a um mesmo universo de expectativas políticas e um mesmo modo de governo (como veremos mais detalhadamente no próximo Capítulo).

Em segundo lugar, deve-se ter em mente que a transição para o fim do Maximato se deu com a chegada de Cárdenas ao poder, no exato mesmo ano em que Ramos publicou $E l$ perfil. Cárdenas era homem de Calles, é verdade, e tal como os três presidentes anteriores chegou ao cargo mais alto do poder executivo mexicano por indicação do Jefe Máximo. Porém, meses depois rompeu com ele, e passou a operar uma política de alcance social que 
vem sendo considerada, naquele país, como ímpar. Ela não é, entretanto, especificamente considerada nesta Tese, porque corresponder a um período em que o texto original do referido ensaio já havia sido completamente elaborado e publicado. 


\subsection{A "revolução" em outros textos da década de 1930, no Brasil e no México:} debates cruzados

A presente seção tem como objetivo localizar as considerações de Holanda e Ramos, acerca do conceito de "revolução", desenvolvidas, respectivamente, em Raízes e El perfil, ante as proposições, a respeito, apresentadas por contemporâneos seus, no Brasil e no México - entre ensaístas e expoentes das vanguardas.

No Post-scriptum de Retrato do Brasil, Paulo Prado considerou o termo "revolução", tal como Holanda, em sua pluralidade de sentidos. Para ele, e usando palavras dele, poderia ser empregado para designar "simples revolta de soldados", "investida disfarçada para a conquista do poder - forma predileta nos povos de meia civilização", ou - o desejado movimento "mais fundo", "radical" que "apagaria tudo o que foi mal feito" da estrutura psicossocial de um povo, de uma nação (PRADO, 2001, p. 209).

No referido comentário a seu ensaio mais célebre, ainda, Paulo Prado demonstrou, não sem receito, certa conformidade com a necessidade de que uma revolução, nesse terceiro sentido de revolução, se efetivasse em nosso país. Entretanto, por fim não definiu que tipo de revolução "mais funda", "radical” desejava.

Também em Bomfim, ao longo de sua carreira, o termo "revolução" é apresentado como termo passível de ser empregado em circunstâncias distintas, sob diferentes propósitos.

Em América Latina: males de origem afirmou que, ao ver dos europeus, nossas "revoluções" eram nada mais que "levantes": "substituem-se governos amiudadamente; os partidos políticos lutam frequentemente à mão armada, em guerras encarniçadas, que duram anos, às vezes” (BOMFIM, p. 44). Contudo, conforme Bomfim, em geral tais mobilizações pouco de novo traziam; nossa política tendia a ser marcada por continuidades e conservadorismo. Conforme Bomfim, "até revolucionários" "acha[riam] sempre o meio de explicar que não querem ser mais que conservadores" (Idem, p. 178); "são revolucionários [portanto] até a hora exata de fazer a revolução" (Idem, p. 182).

Em um Posfácio a Brasil nação, quer dizer, a livro elaborado após as alterações institucionais promovidas por Vargas e seus assessores, desde o golpe, Bomfim deixou de lamentar nosso caos político e passou o criticar o fato de que em nosso país tal palavra fosse empregada de forma quase aleatória, num sentido positivo mas ideologicamente corrompido, para designar toda sorte de "movimentos armados, rebeliões militares, assalto ao poder, com a vitória final dos rebelados"; cujo potencial de transformação tendia a esmorecer com o tempo (BOMFIM, 1998, p. 667). Nessa circunstância, Bomfim se refere, pois, aos acontecimentos 
designados "Revolução de 1930": "tal agitação, por mais vasta e profunda que tenha sido, limitou-se, de modo absoluto, ao mundo político dos governantes tradicionais. (...) Não traz substituição de gentes, nem de programas, nem de processos" (Idem, p. 688).

Dos ensaístas brasileiros abordados no Capítulo anterior, dentre aqueles que publicaram após os acontecimentos de 1930, quer dizer, Bomfim, Holanda, Freyre e Caio Prado Junior, apenas o primeiro se referiu claramente a Vargas. Quatdo aos demais, apresentaram todos reflexões sobre o conceito de "revolução", e também todos sobre os costumes políticos dos brasileiros contemporâneos, mas não mencionaram, em nenhum momento das obras aqui selecionadas, o novo governo, em voga.

O tema da "revolução" era, evidentemente, ponto nodal da reflexão de Caio Prado, marxista. E, cuidadoso, tal autor, tal como Holanda, Paulo Prado e Bomfim, preocupou-se em diferenciar as abordagens tradicionalmente conferidas a ele, definindo, em Evolução política do Brasil, como verdadeiramente revolucionárias alterações político-institucionais que se davam em razão de interesses das massas, assim como motivados por mudanças econômicosociais profundas. Criticava, destarte, tal como Paulo Prado, Bomfim e Holanda, o costume, por muitos estadistas brasileiros, de se dizerem "revolucionários", embora intentando tão somente chegar ao poder, e impor seus propósitos pessoais, familistas e de classe.

De forma pioneira, esse autor considerou, no referido ensaio, alguns movimentos populares que ocorreram no interregno em que D. Pedro I renunciou e D. Pedro II ainda não alcançara a maioridade: a Cabanagem, a Balaiada e a Praieira. Como desordenadas, lembrou que "não passam, para a generalidade dos nossos historiadores, de fatos sem maior significação social, e que exprimem apenas a explosão de 'bestiais' sentimentos e paixões das massas". Contudo, afirmava, era preciso rever tais pontos de vista; de sua parte, pelo caráter popular, as chamou "revoluções da Menoridade" (PRADO, p. 8-9).

Porém, fato é que, para Caio Prado, mereciam o status de revolução sobretudo alterações históricas, vividas em nosso país, que antecederam a rebeldia de cabanos, balaios e praieiros. Para ele, nossa movimentação político-institucional mais "revolucionária" havia sido a "Revolução da Independência" - já que, mesmo não tendo envolvido ações e reações populares em considerável escala, foi operada por indivíduos que foram bem sucedidos, no sentido de chegar ao poder, dominá-lo e convertê-lo em seu propósito; em uma lógica de produção consideravelmente diversa da anterior consolidada. A Revolução da Independência, como consta em Evolução política do Brasil, equivalia, afinal, à vinda à tona de "diferentes contradições econômicas e sociais que se abrigavam no íntimo da sociedade colonial, e que a ordem estabelecida mantinha em respeito" (Idem, p. 49). 
Tal como para Holanda, assim, para Caio Prado Junior a verdadeira revolução, no Brasil, remetia a movimentações a longo prazo, que haviam começado a se desenrolar ainda no século XIX, e correspondia à libertação das amarras coloniais, e a conformação de um novo modo de se viver, de se relacionar, de se produzir, em nosso país.

Todavia, diferentemente de Holanda, para o ensaísta marxista o último acontecimento mais marcante dessa longa revolução, revolução lenta, não era a Abolição da escravatura, de 1888; a qual teria indicado o enfraquecimento dos poderes monarquistas latifundiários, às vésperas da Proclamação da República. Para Caio Prado Junior, o último acontecimento revolucionário, no Brasil, havia sido era supressão do negócio de venda de mão de obra africana, em 1850, que representava a possibilidade de surgimento de um sistema pautado em novas bases econômico-sociais, não escravocratas. Lemos, destarte, a propósito, em Evolução política do Brasil: "a abolição do tráfico constitui a vassourada preliminar e indispensável de tal surto de progresso"; indicaria a possibilidade de uma "completa remodelação" (Idem, p. 94-95).

Dentre os ensaístas aqui analisados, Gilberto Freyre, portanto, não foi o único que abordou os costumeiros "assanhamentos desordeiros" brasileiros sem grande pesar. Holanda, como vimos seções anteriores, vinha escrevendo, da Alemanha, que a revolução deveria ser considerada uma possibilidade de ação política legítima. Os Prados desejavam, como vimos no capítulo anterior, desde antes da chegada de Vargas à presidência, que pela via revolucionária se rompessem o reacionarismo e os localismos da República Velha; desejo que se desdobrou em intenções diversas, para Paulo e para Caio, no decorrer da década de 1930. E mesmo Bomfim ia se tornando mais radical em seu apelo por uma revolução brasileira.

Mas é Freyre quem apresenta, em sua análise, nossa história cravada por conflitos armados, fazendo uso de um vocabulário culturalista, relativizador, e conformado. É verdade que Bomfim flerta com tal possibilidade, quando descreve um tanto rancoroso o fato de que os estrangeiros, muitas vezes sem nos conhecer verdadeiramente, nos descrevem como povos tipicamente desordenados, impulsivos, caóticos, bárbaros; mas Bomfim, por fim, à sua maneira, concorda com a cruel avaliação de europeus e norte-americanos, nesse quesito, a nosso respeito.

Em Freyre nossas mobilizações populares têm pouco efeito, e isso é peculiaridade nossa que não chega a incomodar profundamente, porque, a seu ver, afinal, não viria causando tantos estragos e alterações. Ele falou, assim, em Casa-grande \& senzala, em certo gosto nosso pelo militarismo, pela disputa armada, pelos combates físicos, pela ambição da 
conquista, e pelo culto ao chefe; e empregou a expressão "tradição revolucionária" (FREYRE, 2001, p. 123).

A forma de Freyre abordar o termo "revolução" como um termo que remete a diversos significados, foi também indicativa dessa descrença no poder transformador e reordenador dos conflitos armados. Ele falou, num tom um tanto irônico, do hábito de "dar-se o pomposo nome de revolução" a toda espécie de movimento político (Idem, p. 124).

Para Freyre, em seu primeiro ensaio publicado, o movimento político-institucional revolucionário por excelência, na história de nosso país, não era, tal como proporia Holanda, a Abolição, nem, como estava propondo Caio Prado, a Independência e o fim do tráfico negreiro. Para Freyre, pernambucano, regionalista, a "Revolução pernambucana de 1817" seria "a única digna desse nome" porque "se revestiu menos do caráter de pura desordem propícia ao saque, ou menos sofreu da deformação de fins políticos ou ideológicos" (Idem, p. 210). O que Freyre assim demonstrava compreender como movimento digno da denominação de "revolução"? Demonstrava compreender como a "nossa revolução": as alterações mais autênticas que se pudessem processar, em sentido positivo, em nosso país; movimentos cujas razões não fossem fortuitas, cujas bases não fossem interesses individualistas; e que não se fundamentassem em ideologias enganosas, apriorísticas. Ele demonstrava, enfim, pretender que a política brasileira seguisse cumprindo um suposto hábito de valorização dos grandes e gentis chefes, interessados/ligados às massas carentes, que partissem de amplo conhecimento delas, e não de ideias pré-formuladas, deslocadas; e que as revoluções seguissem tais referências.

Diferenciando-se de Caio Prado, Freyre não podia considerar a Independência como uma Revolução, porque, para ele, justamente o Brasil colonial fora a base de nossa civilização, e as estacas então fundadas deveriam ser respeitadas. Para Freyre, a revolução, no Brasil, como movimentação "lenta", deveria se processar num sempre-diálogo com o passado, com a tradição, com o que haveria de mais autêntico e próprio, em nossa cultura.

Ora, nesse momento de Casa-grande \& senzala, o ensaísta ousava denominar nosso país "Rússia americana" - curiosa expressão estudada por João Marcelo Ehlert Maia. Conforme Maia, “país 'antigo', marcado pelo peso de uma tradição camponesa arraigada e pela virulência de um debate intelectual sobre as raízes ocidentais ou 'eslavas' de sua sociedade, a Rússia constitui um caso singular de encaminhamento da questão da "modernidade periférica" (MAIA, p. 429). E, a seu ver, "a formulação freyreana [guardaria] semelhanças com o 'populismo' russo": "em ambos os casos haveria a crença nas 
possibilidades civilizatórias contidas no mundo da tradição, e um elogio a instituições sociais que regulavam a sociabilidade 'rural"' (Idem, p. 437).

Maia, entretanto, não observa no horizonte analítico de Freyre interesse pelo tema da "revolução" - notável tanto na Rússia da década de 1930, sob governo de Joseph Stálin, como no Brasil dos anos 1930, sob governo de Vargas. Para esse intérprete, em Casa-grande \& senzala identificava nossa política com a política russa não pelas rupturas, mas pelo respeito às convenções, ao passado. Quando usava o termo "revolução", decerto, Freyre o trazia acompanhado de termos como "tradição", "mística" (FREYRE, 2001, p. 123).

Rocha analisa os ensaios de Freyre em comparação, especificamente, com o dito ensaio de Holanda. Conforme tal pesquisador, afinal, haveria um "eco" de Casa-grande \& senzala em Raízes (ROCHA, p. 247): “É certo que a contenção da escrita de Sergio Buarque jamais chegaria à prosa gorda de quem se criou no embalo da rede, mas a abertura da primeira edição de Raízes do Brasil corroborava o otimismo do sociólogo pernambucano: dicções diferentes, porém afinadas no mesmo tom fundamentalmente positivo" (Idem, p. 248).

A leitura do primeiro Prefácio de Casa-grande \& senzala pode nos ajudar na análise de possíveis identificações entre o autor de Sobrados e mucambos e o autor de Raízes. Nesse texto Freyre definira alguns temas que considerava importantíssimos, a serem tomados em outro estudo; temas que coincidem não apenas com seu livro seguinte, como também com os últimos capítulos do livro de Holanda.

Nos dois textos são consideradas questões fundamentais, a respeito do século XIX, anunciados no mencionado prefácio, como por exemplo: "atitudes" e "tendências" na vida dos brasileiros; a Abolição da escravatura; o recorrente gosto de nossa classe proprietária por atividades burocráticas e pelo ócio; a formação de um "proletariado de condições menos favoráveis de vida do que a massa escrava"; a valorização dos laços familiares; as mudanças nas formas de educar; a crítica ao bacharel desconectado com a realidade (FREYRE, 2004, p. 61-62).

Se considerarmos a problematização histórica, importante destacar que, em determinado momento desse segundo ensaio, Freyre denominou o período que Holanda chamou "Nossa revolução" como "a revolucionária primeira metade do século XIX" (Idem, p. 454).

Conforme vimos no Capítulo anterior, para Elide Rugai Bastos, há, porém, uma importante diferença entre o segundo livro publicado por Freyre, e o primeiro livro publicado por Holanda: enquanto um lamentava a desintegração da tradição; o outro apresentaria certas 
continuidades históricas, comportamentais, sistemáticas, como lamentáveis obstáculos ao surgimento de uma tradição política, social, autêntica, funcional e profícua.

Eu não apostaria, portanto, num viés tão claramente positivo, em Holanda. Como venho argumentando, as mais diversas edições de Raízes alternam entre crítica e inconformismo e esperança - embora as versões posteriores soem menos esperançosas, é verdade.

No México, o tema da "revolução" - como conceito e como fato histórico recente - foi explorado pelos mais diversos ensaístas. Por uma questão cronológica, comecemos considerando a abordagem de Manuel Gamio, em Forjando pátria, de 1916.

Tal como os intelectuais brasileiros antes mencionados, Gamio considerava os usos da palavra "revolução" por grupos movidos por interesses que ele, afinal, julgava pouco transformadores, e de alcance reduzido. E lamentava que "elementos ditos revolucionarios", em território mexicano, fossem, em verdade, nada mais que "gérmenes virulentos de la política de antaño" (GAMIO, p. 144).

Especificamente sobre a Revolução desencadeada, em seu país, seis anos antes da publicação de Forjando pátria, Gamio definia como uma "segunda Independencia", na medida em que "vino a derribar estructuras viciosas"; uma independência mais radical, porque "demolió más alto y cavó más hondo" (Idem, p. 121). Nisso ele se aproximaria de Bomfim, sempre tão crítico da colonização ibérica, Caio Prado e Holanda, no Brasil.

Com foco naqueles acontecimentos recentes, Gamio, entretanto, mas também tal como os ensaístas brasileiros, pontuava que "la revolución aun no termina en todos sus aspectos".

Para Gamio, especificamente, mais do que o fortalecimento militar de novo grupo, ou a legitimidade do poder de novo grupo, faltava vigorar uma "Revolución de ideas" (Idem, p. 121). Daí, importante considerar que ele escrevia às vésperas da elaboração de uma nova constituição mexicana, que seria, afinal, promulgada em 1917. E que, nas páginas de Forjando patria, embora reconhecesse o valor das convulsões populares, demonstrava ansiar pelo "restablecimiento del equilibrio" em "bases fundamentales sobre las que gradualmente [se fuera] construyéndo una organización nacional equilibrada y fuerte" (Idem, p. 134).

Quer dizer: em observação de uma conjuntura nacional distinta, Gamio, se comparado aos brasileiros, chega a definir um item para o desejado programa revolucionário latinoamericano. Um item vago, e que dialoga com as proposições de todos aqueles ensaístas do Brasil, incluindo Caio Prado, e talvez excluindo Freyre: a necessidade de se mudar as "ideias". 
Pode-se questionar se era realmente isso que pregava Holanda, que tantas vezes, como vimos, foi crítico de programas, que em geral limitavam a ação, ou, no mais das vezes, se mantinham num âmbito completamente deslocado da realidade.

Mas não era somente a esse tipo de "ideias" - como ideias programáticas - a que Gamio se refere. Como mexicano do início do século XX, Gamio deseja o fortalecimento das instituições políticas e o estabelecimento de programas, sim. Mas como antropólogo, discípulo de Boas, "ideias" possuem um sentido mais amplo: como modos de pensar, como mentalidade; e "Revolución de ideas" a uma alteração que em certa medida Holanda, em Raízes, deseja.

Nos primeiros textos de A la nación mexicana, Caso também parecia considerar a violência, o caos social, no México do início do século XX, elementos necessários para que se preparasse terreno para transformação; ali escreveu: "mi pueblo (...) tiene más aprendido en sus grandes dolores que en la época efímera de su ventura" (CASO, p. 7); "cada una de sus revoluciones acerca a la patria a la realización de su destino" (Idem, p. 24). Em texto de El problema de México y la ideologia nacional, manteve o argumento: "como nuestras necesidades, a medida que pasa el tiempo, se acumulan y quedan sin satisfacción, adecuada, la única solución posible es la trágica, esto es, la guerra civil” (Idem, p. 69).

Ele sublinharia que, por tais questões internas e específicas, os mexicanos vinham sendo sempre criticados pelos europeus; e rotulados bárbaros. Ao que responde com ironia, em referência ao morticínio da Primeira Guerra Mundial: "las revoluciones horripilan a los europeos occidentales como a nosostros sus guerras infames" (Idem, p. 28).

Para Abelardo Villegas, pois, Caso compreendeu a Revolução como uma catarsis através da qual o mexicano se libertava de uma ordem limitada e limitadora, pautada no material, no racional, no científico; e se permitia ser intuitivo, espiritual, humano (VILLEGAS, p. 51 e 61).

Ele desdobraria, assim, a intenção de Gamio, de uma mudança nos modos de pensar do mexicano.

Mas note que Caso emprega a palavra "revolução" não para se referir a transformações profundas na estrutura social nacional, ou na estrutura mental coletiva, e sim para denominar qualquer mobilização política, qualquer enfrentamento militar que tenha repercutido em alguma transformação administrativa. Assim, ele não percebe as experiências "revolucionárias" recentes, em México, como tão distintas, ou mais profundas, do que as experiências do México colonial, ou do México recém-independente, ou do México pós- 
Reforma Liberal. Revolucionar - nesse momento, para Caso - não chegava a equivaler a ruptura; correspondia a cumprimento de uma certa dinâmica político-social.

Maria del Carmen Rovira Gaspar defende, então, que Caso, afinal, sempre se preocupara com a tendência caótica da política mexicana; e, nesse sentido, com a aparente falta de propósito dos movimentos sociais desdobrados a partir de 1910 (ROVIRA, p. 304305). Tal autora cita, então, uma passagem da obra de Caso, sem indicar a data de composição ou da primeira publicação dela, mas a qual, ainda assim, me parece ser interessante transcrever. Conforme a professora, Caso teria declarado, oportunamente, que considerava “difícil vencer la amargura que deposita[va] día a día en el alma el desarrollo aún no terminado, y que parece interminable, de una revolución” (Apud. ROVIRA, p. 306).

Em A la nación mexicana Caso efetivamente declarara: "Ya es tiempo de que los pueblos de esta parte del mundo demostremos nuestra aptitud para la civilización; de que los mexicanos especialmente, lejos de matarnos unos a otros como hemos hecho con singular predilección desde que se consumó la independencia nacional, sepamos cumplir nuestro destino" (CASO, p. 20).

Já no livro posterior, El problema de México y la ideologia nacional, o temor ante a possibilidade de novas revoluções, guerras civis, novos "cuartelazos", no México, o fez falar em "tragédia de la revolución" (CASO: 162) e denominar a Revolução Russa como “desenfreno ruso" (Idem, p. 103).

Quanto a Vasconcelos, registrou em ensaio uma crítica mais sistemática ao conceito de "revolução" apenas no ano de 1937. Então, vinha a público seu ¿Que es la revolución?, no qual o ex-secretário pontuava que o recurso à violência fora senão necessário, inevitável, no México; mas no qual, em sentido semelhante ao de Gamio e Caso, insistia que o prolongamento da desordem correspondia a um sério risco.

Ao ver de Vasconcelos, pois, tardava a hora de converter o caos social em projeto estatal; de se contrapor, à bem vinda destruição do sistema porfirista, a construção de um México livre e culto. "La fundamental justificación de los sacrificios que demanda una revolución, es que ella sea medio para crear un estado social más justo y más libre que el régimen que se ha destruido, o se intenta destruir" (VASCONCELOS, 1937, p. 91).

Vasconcelos, assim como Gamio e Caso, e diferentemente do horizonte de preocupações dos brasileiros, portanto, apresentam como transformação mais ansiada uma transformação cultural, nos modos do mexicano. E também tal como seus conterrâneos e diferente do que em geral se deu à época, em nosso país, anseia pela elaboração de um programa ou de regras que o viabilizem. 
Se compararmos o emprego do termo "revolução" por esses autores mexicanos, com o emprego por parte dos autores brasileiros, verificamos, pois, que embora os governos de México e Brasil, naquelas primeiras décadas do século XX, se designassem "revolucionários", naquele país os intelectuais lidaram com a questão como uma questão mais pontual e fática.

Para Gamio, Caso e Vasconcelos, "revolução" eram acontecimentos, físicos, materiais, visíveis; que mereciam um direcionamento racional e legal. Para Bomfim, Caio Prado e Holanda, a Revolução de 1930 era revolucionária apenas no discurso; embora em verdade o Brasil de então cumprisse etapas de uma rota revolucionária, quase invisível porque profunda.

Podemos dizer, então, ademais, que Ramos, em El perfil, apresentou uma reflexão que tinha pontos identificáveis com esses dois grupos de interpretação. Por um lado, como mexicano, esteve atento aos conflitos desenrolados nos campos e nas cidades, desde que era muito jovem, e se identificou mas incomodou com eles, desejando que novos padrões políticos se perfizessem. Contudo, por outro lado, como intelectual representativo de uma geração posterior à de Gamio, Caso e Vasconcelos, e contemporânea a Holanda, Caio Prado e Freyre, buscou observar a questão, e pensar esses padrões políticos, através de parâmetros culturalistas distintos, e de uma composição histórica diferenciada.

Ainda que Ramos partisse de muitos dos pressupostos compartilhados por seus antecessores, El perfil foi, logo, escrito em um momento em que se sentia que as expectativas no sentido de normatização política já deveriam ter sido há muito cumpridas. De maneira que tal autor, sem dizê-los claramente, mas referindo-se a fatos, procederes e práticas, deslocou para o Estado dito "revolucionário", e o Maximato, o mesmo diagnóstico do continuísmo, e do caos social a ser superado.

Se comparamos Holanda e Ramos, então, vemos que ambos estavam interessados em movimentos históricos mais alongados, de transformação, mas cravados de permanências. Além preocupados com a desconstrução dos discursos que serviriam de obstáculo a transformações mais amplas. E ansiosos por uma transformação cultural.

Em se tratando dos expoentes de nossa vanguarda brasileira, pode-se dizer que, tal como os expoentes de nosso ensaísmo, não foi comum abordarem a Revolução de 1930.

Dois literatos cujas obras vem sendo considerada como perpassadas pela problemática revolucionária são o nordestino Graciliano Ramos, e o aqui ainda não citado Carlos Drummond de Andrade, que possuía vínculos com o modernismo paulista: o primeiro no romance Angustia, e o segundo nos poemas de Sentimento do mundo. Ambos, porém, foram bastante sutis em suas referências. 
Também foi sutil a referência de Mario de Andrade à sua decepção com o projeto modernista e sua opção por haver trabalhado com políticas culturais institucionais, em Remate de males. $\mathrm{O}$ mesmo valendo para a crítica de Oswald, que, por exemplo, em $O$ rei da vela, parecem assumir um papel mais de crítica dos costumes e do sistema sócio-político capitalista, do que diretamente e especificamente ao governo de Vargas e suas bases de sustentação.

Já os vanguardistas mexicanos - estridentistas e também os editores de Contemporáneos - por diversas vezes abordaram tanto os conflitos armados pós-1910, quanto o Estado que, na corrente década de 1930, se auto-proclamava "revolucionário".

A Revolução não foi, portanto, apenas tema das chamadas "Novelas de la Revolución”, das décadas de 1910 e 1920. A mobilização dos trabalhadores das cidades foi tema de muitos dos poemas de Maples Arce, que serviu como burocrata ao governo dissidente, revolucionário, do estado de Veracruz; e as mobilizações no campo, de romances de Xavier Icaza. Além disso, a institucionalização do regime implantado pelos caudilhos revolucionários desde Obregón e Cárdenas foi largamente explorada nos versos de Poemas proletários, de Salvador Novo.

Pode-se dizer, porém, que cada um desses dois grupos da vanguarda, no México, abordou a Revolução a partir de um ponto de vista: os primeiros, teriam contribuído para a legitimação de certas mobilizações, e fornecido bagagem retórica para os governos; os segundos, não se teriam engajado em projetos específicos, mas na crítica de todos os projetos.

Sánchez lembra, nesse sentido, que o velho contemporáneo Bernardo Ortiz de Montellanos escreveu, em livro de 1930, que promover uma Literatura dedicada ao tema do processo revolucionário teria "más significación para el público extranjero que para el progreso de la cultura y el desenvolvimiento artístico de nuestro país” (Apud. SÁNCHEZ, p. 217-218).

E não se pode esquecer que, nos mencionados Poemas proletários, Novo lançava uma mesma crítica a determinados lugares comuns dos discursos dos poderes instituídos; como a reiterada ênfase na promoção de alterações profundas, sem que, em verdade, poucas mudanças fossem efetivadas. Nesse mesmo poema Novo destacava, ainda, o serviço prestado, ao Estado revolucionário, pelos "intelectuais", "pensadores" (NOVO, p. 110) e literatos. E reduzia, afinal, a categoria "poesia revolucionária" à mera referência a "tres o cuatro anécdotas de Villa" (Idem, p. 111).

Temos, enfim, no Brasil da década de 1930, um Holanda que, em diálogo com a vanguarda brasileira, negava-se a reiterar a ideia de um Vargas revolucionário; e, no México, 
um Ramos que, ex-aluno de ateneísta, em diálogo com os contemporáneos, passou a negar a ideia de um Maximato revolucionário.

Note, assim, que Holanda e Ramos pontuaram seus argumentos sociologicamente vanguardistas de três tensões principais: entre teoria e prática, entre inovação e continuidade, e entre nacional e estrangeiro. Como eles compreendem as relações entre cara um desses tensionamentos e o que conceberam e/ou esperavam como "revolução" para Brasil e México? Como tais pontos foram explorados, concretamente, na análise de praticas, ideias, leis, costumes, tendências, realizações, no território brasileiro e mexicano, da época em que escreviam seus primeiros ensaios? Como as mesmas questões apareceram nos textos de ensaístas e literatos seus antecessores e contemporâneos? Eis o que veremos no próximo capítulo. 


\section{CAPÍTULO 4: O conceito de "revolução", e outros conceitos coevos}

\subsection{Aleatoriedade, passionalidade, barbárie}

O presente capítulo tem como objetivo avaliar como e/ou se Holanda, Ramos e os ensaístas e literatos vanguardistas com os quais conviveram consideraram a história recente de seus países marcada por um forte índice de aleatoriedade. Nesse sentido, cabe averiguar como perceberam a ação dos brasileiros e mexicanos, através da história; marcada por certa aleatoriedade, passionalidade e tendência para violência e barbárie. E, por fim, que contribuições o diálogo com a psicanálise pode ter trazido à abordagem especificamente proposta em Raízes do Brasil (1936) e El perfil del hombre y la cultura en México (1934).

Como temos acompanhado, os ensaístas brasileiros de maior destaque, assim como a nossa vanguarda literária, não tendeu a abordar a Revolução de 1930 como tema. Mas em Raízes e outros textos contemporâneos a ideia de "desleixo" e "espontaneidade" da ação do brasileiro através da história nacional, da colônia à modernidade, foi recorrente.

Em seu ensaio mais célebre, além do "homem cordial", Holanda trabalhou com o conceito de "semeador", para designar o tipo de colonização portuguesa, na América. Para ele, o semeador/colonizador português se lançou sobre o território americano sem sistema ou projeto, lançando aleatoriamente, dispersamente as bases de uma nova civilização: "cuidou menos em construir, planejar ou plantar alicerces, do que em feitorizar uma riqueza fácil e quase ao alcance da mão" (HOLANDA, 1999, p. 95). Como "a colônia [era] simples lugar de passagem, para o governo como para os súditos" (Idem, p. 99), houve o marcado desinteresse por investir em projetos urbanos mais complexos e mais próximos dos modos de morar europeus; por locar aqui uma universidade onde os filhos dos grandes proprietários pudessem estudar; por desenvolver um sistema de produção ademais de extrativo, que repercutisse num fluxo de riquezas interno, e de crescimento mais harmonioso.

Holanda retomou, a propósito, uma metáfora criada pelo Frei Vicente do Salvador, que Paulo Prado havia estampado em Retrato do Brasil (1928): a ideia dos colonizadores portugueses terem se concentrado em "arranhar as costas como caranguejos" (HOLANDA, 1999, p. 107; PRADO, 2001, p. 200). Afinal, Paulo Prado também tratara do colonizador lusitana como homem focado na ideia de "fortuna rápida" (PRADO, 2001, p. 56); do colonizador lusitano como "tipo perfeito do homem audacioso e sonhador, livre, sem rebuços" (PRADO, 2001, p. 137). 
Alguns anos antes de Prado, e bons anos antes de Holanda também Manoel Bomfim abordara o parasitismo português na América, nos anos mil e quinhentos, caracterizado por uma força de não-pensar, não-refletir, não-criar: "Uma sociedade que viva parasitariamente sobre a outra perde o hábito de lutar contra a natureza; não sente necessidade de apurar os seus processos, nem de pôr em contribuição a inteligência, porque não é da natureza diretamente que ela tira a subsistência, e sim do trabalho do outro grupo" (BOMFIM, p. 66).

Gilberto Freyre apresentou, em Casa-grande \& senzala (1933), o "tipo normal português" como difícil de caracterizar com precisão, justamente por dinâmico, maneável, híbrido; mas não deixou de, além disso, apontá-lo como "imprevidente" e de "pouca iniciativa" (FREYRE, 2001, p. 81).

Em 1924, em declaração pró-modernimo na Academia Brasileira de Letra, Graça Aranha definiu pontos importantes que seriam publicados no livro Espírito moderno, em 1925; da seguinte maneira: "o passado é o pavor, que perdura em cada um de nós. Se pudéssemos dominá-lo, vencê-lo em nosso espírito, contemplá-lo com alma de vencedor, situá-lo com justeza, saberíamos extrair das suas expressões o encanto e a lição" (Apud. TELES, p. 464); “O brasileiro está no período subjetivo; (...) infecção literária que corrompe a política, a arte, a vida" (Idem, p. 462).

Num mesmo esforço de relacionar passado e passado recente, ou presente, o futuro crítico de Aranha, Holanda, caracterizaria as últimas décadas da história nacional, pela “desordem" (HOLANDA, 1999, p. 188) que se buscava solucionar com a imposição de certas fórmulas políticas (IDEM, p. 178). Sobre nossas ações, ditas revolucionárias, vimos no capítulo anterior, em geral correspondiam, para ele, a "remoinhos de contendas políticas" (Idem, p. 181).

E em Brasil nação (1931), alguns anos antes, Bomfim apontara que a política brasileira não cumpria um "programa meditado"; seguiam "puro instinto" (BOMFIM, 1998, p. 42).

Quanto à Revolução Mexicana, vinha sendo caracterizada, naquele país, como um processo aleatório, desde seus primeiros anos. O historiador David Bailey destaca, por exemplo, que os autores porfiristas que escreveram sobre ela a apresentaram como um movimento destituído de qualquer sentido racional, e portanto necessariamente maléfico (BAILEY, 1979, p. 4).

Saudoso do período no qual Porfírio Díaz governara o México, o poeta José Juan Tablada, por exemplo, teria declarado: “Ojalá y ningún hábito de pasión humana venga a turbar mi recogimiento místico, ojalá y ninguna infamia de la vida, ninguna degradante 
vulgaridad traspase los muros de mi jardín y venga a recordarme que soy un hombre, un mísero ciudadano de la patria que asesinan y despedazan carrancistas y zapatistas" (Apud. MONSIVÁIS, p. 176).

No México como correspondente jornalístico desde princípios da década de 1910, o comunista John Reed realizou uma busca crítica das razões pelas quais os mexicanos haviam iniciado a Revolução. Tendente a traçar um perfil elogioso do povo que se rebelava, acabou, todavia, por também desenhar uma imagem do revolucionário mexicano como assistemático, confuso, irresponsável, irracional, passional; como ser que enfrenta as dificuldades imediatas sem muito planejar para - ou crer em - um futuro mais além (REED, p. 136).

Dentre as razões pelas quais os homens entrevistados por Reed declararam ter se envolvido nos combates em prol da Revolução, ele registrou, em México insurgente (1914), a aleatoriedade. Um jovem combatente the havia dito, por exemplo: "luto para conseguir um rifle 30-30 de algum federal morto e um bom cavalo de algum milionário" (REED: 104); e outro, mais experiente, confirmara a tendência: "estava lutando por um uísque melhor" (REED, p. 210).

Mariano Azuela retomou a tese da aleatoriedade da Revolução, mas o fez - está claro - com outras pretensões; lançou mão da Literatura para operar sua crítica à história recente do México. Em Los de abajo (1916), um de seus personagens declara: "La Revolución es el huracán, y el hombre que se entrega a ella no es ya el hombre, es la miserable hoja seca arrebatada por el vendaval" (AZUELA, p. 69). No final de seu livro há, ainda, uma belíssima metáfora que merece ser aqui transcrita. Quando perguntam a Demétrio, o general revolucionário protagonista, o motivo pelo qual seguia chefiando seu bando, ele reage de maneira entristecida, confessando que não há uma razão específica; então lemos: "Demetrio, las cejas muy juntas, toma distraído una piedrecita y la arroja al fondo del cañón. Se mantiene pensativo viendo el desfiladero, y dice: - Mira esta piedra cómo ya no se para..." (AZUELA, p. 148).

Os personagens de Azuela são, assim, tristes e confusos (nos inspirando compaixão), desordenados, imprevidentes, imprevisíveis; refletindo a insatisfação do autor com o que a Revolução tinha representado, até então.

Lembrando bastante o texto de Azuela, o estridentista Xavier Icaza, em La hacienda, conto integrante do romance Gente mexicana (1924), apresenta a questão agrária não como uma questão de princípios, como início de uma verdadeira, radical e fundamental mudança econômico-social, no México. 
Por fim, a dinâmica revolucionária descrita por Guzmán, tanto em El águila y la serpiente (1928) como em La sombra del caudillo (1929) replica a percepção da Revolução como um movimento que compunha fluxos desordenados.

A definição que Ramos apresenta em El perfil, acerca do processo revolucionário - ao menos aos primeiros anos -, implica a mesma percepção, e se dá através de metáfora bastante semelhante à proposta por Holanda, para muitas dos movimentos ditos revolucionários no Brasil ("remoinho"), e por Azuela, no México (furacão): em seus anos iniciais a Revolução era, para Ramos, como "un remolino circulante que trastornaba cuanto encontraba a su paso" (RAMOS, p. 136).

Consta em El perfil que os mexicanos vinham sendo passionais desde há muito; e, a seu ver, teriam aprendido a assim agir por influência cultural do colonizador espanhol. Lembrando bastante o que aventava o ensaio brasileiro nesta Tese focado, pois, nesse ensaio mexicano também a Revolução aparecia como uma aventura desmedida, resultado de ações impulsivas, que envolviam grandes riscos assumidos por homens apaixonados; e que remetiam à grandiosa e irresponsável aventura da conquista da América, pelos hispânicos (RAMOS, p. 106).

Tal como Ramos, em El perfil, também Caso concebera o espanhol colonizador como um aventureiro. Em artigo de 1910, publicado como capítulo de Discursos la nación mexicana (1922), ele o apresentava como heroico, ambicioso, imaginativo, entusiasmado, movido por uma energia que não enxergava obstáculos. (CASO: 16). Essa condição de aventureiro, essa energia, essa força espiritual, herdada pelos mexicanos dos espanhóis, deveria ser repensada, reformulada, mas não negada; porque, afinal, a seu ver, os hispânicos eram o principal elemento cultural, conformador do modo de ser do homem do México.

Dentre os ensaístas brasileiros, Freyre defendera que os portugueses, em seu desleixo, e ante as dificuldades dos trópicos (inesperadas, diversas de tudo que conheciam), e elaborado um modo de vida concentrado, complexo e próprio; quer dizer: de sua forma específica, haviam sido incrivelmente bem sucedidos. (FREYRE, 2001, p. 167).

Já Holanda, criticara a tendência - não recente mas cada vez mais imperativa - de se tentar reverter nossa desordem e desleixo em ordem pré-fixada. Então, sugerira, a respeito da história recente de nosso país: "Podemos ensaiar a organização de nossa desordem segundo esquemas sábios e de virtude provada, mas há de restar um mundo de essências mais íntimas que, esse, permanecerá sempre intacto, irredutível e desdenhoso das invenções humanas. Querer ignorar esse mundo será renunciar ao nosso próprio ritmo espontâneo, à lei do fluxo e refluxo, por um compasso mecânico e um a harmonia falsa" (Idem, p. 188). 
Antonio Arnoni Prado credita que aí Holanda replica uma das mais fortes máximas modernistas (PRADO, 2006, p. 301). Oswald de Andrade, por exemplo, reverteria a ideia de um possível atraso nosso, por conta de nossa dificuldade a agir racionalmente, e elogiaria nossa ação impulsiva, para além de roteiros. No Manifesto Pau-brasil, o grande poeta brasileiro falava da "reação contra todas as indigestões de sabedoria" como "o melhor de nossa tradição moderna"; no Manifesto Antropófago, assegurava: "nunca fomos catequizados" (Apud. TELES, p. 506).

E mesmo autores tidos como mais intelectualistas, por Holanda, como o próprio Graça Aranha e Mario de Andrade, valorizaram nossa espontaneidade, nosso desleixo, nossa razão não-cartesiana. O primeiro, na conferência que abriu a Semana da Arte Moderna, falou em nosso "livre e fecundo subjetivismo", e defendeu "liberdade absoluta" (Apud. TELES, p. 417). O segundo propôs que "a impulsão lírica" brasileira seguisse sendo "livre", “independendo da nossa inteligência” (Idem, p. 445).

Vimos que o mestre de Ramos, o ateneísta Antonio Caso, em suas conferências na década de 1910, havia trabalhado a aleatória história política mexicana como uma especificidade e não como um índice de inferioridade (CASO, p. 28). E Ramos, também: para ele, muitas de nossas guerras chegariam ao fim sem que aparentemente nenhum dos lados por vezes, como no caso da Revolução Mexicana, muito mais do que dois lados - houvesse alcançado vantagem alguma; não porque os mexicanos fossem bárbaros ou degenerados. Isso ocorria porque as guerras latino-americanas não teriam como fundamento interesses racionais, projetos políticos ou econômicos, e sim "paixões” (RAMOS, p. 162-163).

Todos esses autores, portanto, de certa maneira revertem a ideia de uma aleatoriedade para a ideia de que agiríamos conforme outra lógica: a lógica da paixão. Daí em Raízes, ler-se que "os movimentos aparentemente reformadores, no Brasil (...) foram de inspiração intelectual, se assim se pode dizer, tanto quanto sentimental" (HOLANDA, 1999, p. 160).

$\mathrm{Na}$ década de 1930 se tornou corrente que as noções de que passionalidade/ sentimentalismo e afeto estariam associadas e seriam características dos povos economicamente subdesenvolvidos; e de que assim rompíamos os rigores da dinâmica capitalista, permitindo que se viesse a fundar, entre nós, um novo estilo de vida, mais humano, plural, e efetivamente democrático.

Haveria toda uma tendência a se apresentar o brasileiro, o mexicano como seres espontâneo e dóceis, logo, caracterizados por comportamentos que deveriam inspirar os rígidos e egoístas europeus e norte-americanos. Para Roger Bartra, em La jaula de la melancolia (1996), muitos de nosso pensadores teriam concebido os latino-americanos como 
possuidores de uma "agressiva emotividad" que resiste a "imersion en la fria tecnologia" e aos "aires de la sociedad industrial moderna" (BARTRA, p. 124).

Esse movimento se fez de fora para dentro, em razão, talvez, em grande parte, da Primeira Guerra Mundial e da percepção de quão violentos, individualistas e pouco nobres de espírito as nações ditas civilizadas poderiam vir a ser. Mas também de dentro para fora, com certo resgate da autoestima latino-americana.

As descrições de Ribeiro Couto e Cassiano Ricardo, aqui já aludidas, a respeito de uma dada hospitalidade brasileira incluem, afinal, esse movimento centrípeto e centrífugo.

Mario de Andrade, em Noturno de Belo Horizonte, publicado em Clan do jaboti (1927), escreveu:

O amor não é uma paz/ E é por amor que Deus nos deu a vida.../ O amor não é uma paz, bem mais bonito que ela,/ Porque é um completamento!.../ Nós somos na Terra o grande milagre do amor! E embora tão diversa a nossa vida/ Dançamos juntos no carnaval das gentes./ (...) Que importa que uns falem mole descansado/ Que os cariocas arranhem os erres na garganta/ Que os capixabas e paroaras escancarem as vogais?/ (...) Juntos formamos este assombro de misérias e grandezas, Brasil, nome de vegetal... (ANDRADE, 1980, p. 136).

Em Retrato do Brasil, publicado um ano depois, Paulo Prado sugeriu que nossos colonizadores foram mais dóceis do que os "invasores castelhanos", que, "nas outras regiões do continente", se caracterizaram por uma ação "violenta", "sanguenta" (PRADO, 2001, p. 98).

Também Bomfim, em América Latina: males de origem (1905), embora dissesse que portugueses e espanhóis compartilhassem o mesmo "gênio", o mesmo "pensamento" - "a história é a mesma" (BOMFIM, p. 89) -, os espanhóis teriam sido mais "vorazes", e portanto mais "violentos" durante o processo de conquista (Idem, p. 107).

Conforme Dante Moreira Leite, Freyre, autor de Casa-grande \& senzala, "embora tenha uma documentação muito grande a respeito do sofrimento dos escravos, continua a afirmar que, de modo geral, suas condições de vida não eram más” (LEITE, 2007, p. 367).

Para Freyre, a "voz bem brasileira" era caracteristicamente "acomodatícia" (FREYRE, 2004, p. 29); “o abraço, hoje tão do ritual brasileiros da amizade entre os homens, (...) acompanhado pelas palmadinhas convencionais nas costas" (FREYRE, 2004, p. 743); "ninguém como eles é tão amável; nem tem um riso tão bom; uma maneira mais cordial de oferecer ao estranho a clássica xicrinha de café, a casa, os préstimos” (Idem, p. 791).

Freyre considera os possíveis fundamentos étnicos, biológicos, naturais desse comportamento: seria simpático, "evidentemente, o brasileiro que tem sua pinta de sangue 
africano ou alguma coisa de africano na formação de sua pessoa; não o branco ou o 'europeu' puro, às vezes cheio de reservas; nem o caboclo, de ordinário, desconfiado e que ri pouco" (FREYRE, 2004, p. 791).

Entretanto, essa simpatia "não [lhe] parece ter origem principalmente étnica"; "é antes um desenvolvimento social" (Idem, p. 791). "Esse desejo de intimidade com as pessoas nos parece vir, não só de condições comuns a todo povo ainda novo, para quem o contato humano tende a reduzir-se à maior pureza de expressão, como, particularmente, de condições peculiares ao período de rápida ascensão de um grupo numeroso, da população - o grupo mulato - ansioso de encurtar, pelos meios mais doces, a distância social entre ele e o grupo dominante" (Idem, p. 793).

Num mesmo sentido de relativização dos termos, Ramos avaliava, na terceira edição de seu referido ensaio, desvantagens e vantagens de ser governado por um chefe "apaixonado": por um lado, tais chefes seriam, lamentavelmente, utópicos, vaidosos e egoístas; mas por outro, positivamente, impulsivos, dinâmicos (RAMOS, p. 164-165).

Não podemos esquecer que Ramos também considerara em El perfil a presença do fator "paixão" na atividade intelectual, no México. Por um lado, apontou Abelardo Villegas, ele criticava o intuicionismo dos ateneístas, "porque fomenta la pereza del hispanonorteamericano" e porque desviaria os mexicanos do que eram realmente, para uma quimera do que deveriam ser (VILLEGAS, p. 113 e 119). Por outro lado, acrescentou Villegas, Ramos podia ser considerado, de alguma maneira, também um "vitalista", porque amava a vida, não em sua estreiteza biológica, mas em sua espontaneidade, em sua dinâmica própria, que inspira esperança (Idem, p. 116).

Se tomarmos artigos publicados por Ramos antes de El perfil, vemos essa tensão repetida várias vezes. A respeito dos ateneístas, afirmou ter sido "un tanto equivocado abogar por la intuición en un país en que hace falta la disciplina de la inteligencia”, em um país em que são difusas as noções de "trabajo y disciplina” (Apud. DEL VALLE, p. 94).

Porém, a respeito do porfirismo não deixou de sublinhar que "esos abusos de la razón que condujeron a la desumanización del conocimiento" (Idem, p. 98).

Note que sua perspectiva corresponde à de um homem que critica o irracionalismo mexicano, ainda que valorize sua dinâmica apaixonada; um homem que deseja paz e a legítima institucionalização do Estado de Direito em México, mas não quer negar a autenticidade e originalidade e importância da Revolução Mexicana. Para Ramos, enfim, racionalizar era importante, mas viver, amar, sonhar também. 
Vasconcelos considerava que a Ibero América era um continente povoado por uma "raza emotiva". Escreveu, em La raza cósmica (1925), que por isso não deveríamos nos lamentar. Primeiro, porque, a seu ver, em nossa história, teria sido "abundancia de amor" que teria permitido "a los españoles crear una raza nueva con el indio y con el negro" (VASCONCELOS, 2000, p. 165).

Depois porque, conforme ele, por sermos historicamente emotivos nos caberia a função de, no futuro, "sentar los principios de una [nueva] interpretación del mundo", por uma nova raça, mestiça, "cósmica". Aí então "las emociones se manifiesta[rán], no en el imperativo categórico ni en la razón, sino en el juicio estético, en la lógica particular de las emociones e de la belleza" (Idem, p. 137).

É claro que nas entrelinhas de Ulises criollo (1935) podemos notar que essa percepção se altera um tanto. Mas a ideia do mexicano amoroso se manteve, até onde pôde. Conforme Javier Garciadiego Dantan, embora Vasconcelos se sentisse, então, um "filósofo frustrado", se vangloria ao longo das páginas dessa outra obra "de la enorme felicidad que disfrutó durante el gobierno maderista, dado que [antes de a Revolução se perder, com os sonorenses] gozaba de independência, abundancia y amor" (GARCIADIEGO, 2000: 623).

Em conferência proferida no Rio de Janeiro, e publicada como capítulo do livro Discursos la nación mexicana, Caso apontava como base cultural do México, Brasil, Peru, Chile, Argentina e Uruguai - países pelos quais vinha viajando - a "generosa e humana" cultura latina (CASO, 1976, p. 7). Ramos criticava Caso por não ter tirado muito proveito de suas expedições pela América Latina, tal como Vasconcelos, que viajara por países latinoamericanos a divulgar a imagem de um México revolucionado e civilizado, e que retornou à terra natal com o projeto de valorização da raça comum, da "raça cósmica". Porém, a leitura do texto dessa conferência de Caso na capital brasileira nos demonstra que, pelo menos naquele momento, sim, ele se interessava por pensar o México integrado ao subcontinente ibero-americano - ele se refere, ali, a uma "imperiosa voz de la raza"; e considera o papel da Ibero América na formulação de um novo pensamento, de um novo ser, contemporâneo “estréchandose el amor” (Idem, p. 10).

Em artigos posteriores, da década de 1920, Caso observou a questão com mais cuidado. Defendeu, então, que a "paixão", característica do mexicano fosse substituída pela "compaixão"; que "el amor (...) significa descanso y no arrebato; confianza y paz" (Idem, p. 90).

Segundo críticos recentes, por si só a versão que defende que a saída de Díaz do poder resultou de uma violenta disputa é um mito. Na verdade, o ditador teria resistido o quanto 
pôde às pressões por mudança política, e por fim abandonou a presidência sem maiores riscos, no que diz respeito à sua integridade física. Nas palavras de Jaime Sánchez Susarrey, por exemplo, tudo se passou sem "grandes batallas ni derramamiento de sangre" (SÁNCHEZ, 2010). Nas de Sergio Sarmiento, "las batallas de la Revolución fueron relativamente pequeñas"; "las bajas se elevaban apenas a algunos centenares"; a maioria das mortes se teriam dado em razão da miséria e estagnação produtiva que as ameaças de contendas geraram, e não propriamente devido a conflitos (SARMIENTO, 2010).

Para mim, porém, mais do que voltarmo-nos aos "fatos" que conformam o processo revolucionário, e certificarmo-nos se foram sim ou não consideravelmente violentos, cabe pensar a maneira como governantes e intelectuais identificados à Revolução Mexicana trabalharam o tema da violência. E, claro, a inserção do Perfil de Ramos nessa tradição discursiva.

Conforme Bartra, a brutalidade do processo revolucionário não só foi convertida em forte símbolo, mas em símbolo positivo. Contudo, me pergunto: é possível que essa iconização e positivação realizada a partir da leitura de livros concebidos no momento da Revolução, tenha se dado sem que esses livros tenham apresentado versões tão docemente elogiosas do agir violento? Consideremos, pois, os discursos dos mexicanos que viveram a experiência revolucionária dos primeiros anos.

Antes de mais, tenhamos em mente que o período de lutas do general porfirista Victoriano Huerta, em prol da deposição de Madero, foi denominado, à época, "decena trágica". Ele culminou no assassinato do presidente revolucionário, e na chegada de Huerta ao poder; e desencadeou a reorganização de exércitos fortes, liderados por combatentes do porte de Pancho Villa, Emiliano Zapata, Venustiano Carranza, Álvaro Obregón. Correspondeu, destarte, a uma etapa da história da Revolução então sentida sim como consideravelmente sangrenta (CARMÍN; MEYER, p. 54).

É sobre ela que escrevem Reed e Azuela em seus dois livros clássicos, que certamente estão entre os livros referenciais para que se pensasse, nas décadas seguintes, a Revolução como uma realização violenta. Basta saber se nos textos de México insurgente e de Los de abajo a violência é mesmo tida como essencial no mexicano e no processo revolucionário; e se já é positivada, ou não.

Os "personagens" de Reed são machistas, beberrões, sujos e maltrapilhos, e têm certo orgulho de sua rusticidade - cultivam piolhos e carrapatos. Aqui cabe, ainda, fazer alusão a um detalhe, já aludida: conforme Reed, Pancho Villa se caracterizaria por "uma linguagem 
vulgar", bastante típica de homens pertencentes à "classe mais pobre", aos quais era comum chamar-se "pelado" (REED, p. 156).

Contudo, ainda que os "personagens" de Reed sejam destemidos e audazes, não são necessariamente sanguinários. Esse autor, a bem da verdade, parece dedicar-se a convencer os leitores de que os mexicanos são homens primitivos, e por isso ao mesmo tempo em que toscos e potencialmente violentos, também puros, inocentes. Então, Reed ousa desafiar críticos que rotulam o México como pátria de selvagens amantes da violência; e escreve: "deem-se (...) o trabalho de fazer um inquérito no exército maderista, perguntando se querem a paz ou não! O povo está cansado da guerra.” (Idem, p. 67).

Em suma: ao contrário do que diria Bartra sobre a tradição dos primeiros escritos sobre a Revolução, para Reed os mexicanos não "são" violentos, mas reagem brutalmente à insegurança e às desigualdades; além disso, seus atos de violência não são vistos pelo autor como positivos, ainda que, sim, em última instância, uma forma de se fazer justiça.

Tal como os "personagens" de Reed, os de Azuela se caracterizam por contrastar certo senso de civilidade com uma dada rusticidade; ao que me parece, porém, no caso desse autor, mexicano, a balança pesa um tanto mais para o segundo pêndulo.

Eu diria, porém, que em Azuela tampouco a violência é proposta como característica "essencial" do mexicano; ela resulta da ausência de referenciais, de autoridade, de segurança. Ela também não é absoluta; ao mesmo tempo em que é criminoso, o mexicano revolucionário conhece a necessidade de se pensar de forma justa, de se fazer justiça. Como a tendência a ser criminoso ali prevalece, afinal, ao ver de Azuela essa não podia deixar de ser vista como um sério problema.

Conforme Carlos Montemayor, as duas mais célebres Novelas de la Revolución são, afinal, denúncias da barbárie que representou o processo revolucionário, no México. A primeira, Los de abajo, denunciou "la barbarie de la guerra"; a segunda, La sombra del caudillo, "la barbarie del poder político" (MONTEMAYOR, p. XVI).

Parece-me que, nos dois textos de Guzmán aqui selecionados para análise - tanto $E l$ águila y la serpiente como La sombra del caudillo trabalham com essa noção de barbárie sobreposta à de civilização; e o fazem de maneira que a barbárie fica sendo mais característica dos chefes (retratados) do que do povo comum (pano de fundo).

Em uma célebre passagem da primeira, o capítulo intitulado La fiesta de las balas, o autor narra o assassinato de trezentos huertistas por tropas ligadas a Villa, chefiadas por Rodolfo Fierro. O assistente de Fierro cumpre todas as determinações dadas, mas a todo tempo demonstra desconforto. Não tem coragem de erguer os olhos para mirar a matança. 
Depois, se deita para dormir, mas pronto se levanta, ajoelha e reza, se persigna. Sobre esse personagem, Guzmán escreve: "Recordó entonces la ejecución de los trescientos prisioneros, y el solo recuerdo lo dejó quieto sobre la paja, entreabiertos los ojos" (GUZMÁN, 1941, p. $74)$.

Por outro lado, o próprio general, Fierro, ou revela certo descaso, ou se esforça por parecer fazer pouco caso. Guzmán investe algumas boas páginas do relato descrevendo o comportamento dele antes de ordenar que seus encarregados trouxessem os huertistas apreendidos para serem executados, causando-nos a impressão de que ele vacila na decisão, hesita. Mas depois parece se deitar tranquilo. Então, quando seu sono é incomodado pelo pedido de água, por um dos prisioneiros moribundos, ele se dirige ao assistente: "iQue te levantes y vayas a darle un tiro a ese hijo de la tiznada que se está quejando! ¡A ver si me deja dormir!" (Idem, p. 80).

Em La sombra del caudillo essa percepção se repete. A massa é ali descrita como composta por homens materialmente e espiritualmente humildes, dóceis, brandos - tal como um rebanho, tal como órfãos (GUZMÁN, 2002, p. 85). É rústica, de fato, mas não impulsiva ou grosseira. Pode-se notar nela, até mesmo, um tipo de "inteligência" e bondade, sutis, que implicariam identificação com o apelo do deputado Axkaná por um caminho de verdade e decência para México.

Contudo, essa força latente seria mal canalizada por uma elite corrupta e mal intencionada.

Cabe, neste momento, destacar: sim, a nota de aleatoriedade, insegurança e brutalidade, no México, continuou entoando discursos de diversos líderes revolucionários mesmo após a deposição de Huerta, e em momentos tidos como, de fato, de relativa paz. Como contam Hector Aguilar Camín e Lorenzo Meyer, Obregón dirigiu-se à sua oposição no Senado, quando era presidente, da seguinte maneira: "Nossos inimigos deveriam se apressar em afiar suas adagas e apontar seus rifles assassinos porque a guerra é sem quartel, dente por dente, vida por vida” (CAMÍN; MEYER, p. 58).

Diz-se que Martín Luis Guzmán escreveu La sombra del caudillo inspirado na história de Francisco Serrano, aliado de Obregón e Calles, posteriormente acusado de traição, e assassinado a mando deles num episódio que ficou conhecido como "masacre de Huitzilac". Conforme Ignacio Almada Bay, o ocaso de Serrano é prova contundente da "vocación fratricida", do "baño de sangre hermana" que caracterizou mesmo os governos revolucionários ditos “institucionais” (ALMADA BAY, 2008, p. 202). 
Susana Quinsanilla se refere a uma carta enviada por Guzmán a Reyes, logo que chegou à Espanha, em 1925; e sublinha o descontentamento, a tristeza e a revolta dele, com a violência que caracterizava a cultura política mexicana. Escreve a pesquisadora:

"prácticamente todos los grandes hombres con los que Guzmán había convivido estaban muertos. Ninguno de ellos por enfermedad u otra causa 'natural'. (...) ¿Por qué? Porque en 1924, año de la elección de Calles como presidente de México, un 'clan de asesinos' se había adueñado del poder (QUINSANILLA, 2010, p. 78).

No texto de La sombra del caudillo, Ignacio Aguirre é um jovem general, cuja personalidade é identificável à de vários dos militares que lutaram pela Revolução. Para desenhar seu perfil, o autor recorreu à descrição de diversos hábitos aparentemente desimportantes do personagem; mas hábitos que nos ajudam a considerar o que parecia ser importante para um líder, àquela época: a masculinidade, um quê de rusticidade/brutalidade, a força. Aguirre, então, conserva uma amante, bebe em excesso e sempre faz questão de começar a beber de uma garrafa intacta, e, tal como Fierro, aparenta completa ausência de medo. Ao longo de todo o livro nos parece impassível; é, nas palavras de Guzmán, um ser "hermético": oculta bravamente qualquer temor ante à insegurança, característica de seu meio social (GUZMÁN, 2002, p. 33).

De Aguirre a outros personagens de El águila y la serpierte e de La sombra del caudillo, pois, Guzmán parece estabelecer, uma generalização: a todos "la vida les importaba menos que el propósito de no dar espetáculo de flaqueza" (Idem, p. 224). Um dada psicologia que lembra, afinal, o "pelado", definido por Ramos.

Há, por fim, mais alguns dados importantes sobre a escrita de Guzmán. Primeiramente, o fato de que, se todos são culpados, todos são inocentes, presente tanto em $E l$ águila y el serpiente como em La sombra del caudillo: no primeiro livro, mesmo que Guzmán insista em chamar Huerta traidor, declara sentir simpatia pelos huertistas; no segundo, à exceção de Axkaná, todos os personagens são corruptos.

Ademais, tem-se em ambas a obras também que o caos social, a insegurança é que moldam personalidades violentas, é que moldam personalidades reservadas.

Dentre os ateneístas, mesmo Vasconcelos, que em suas reflexões filosóficas, antievolucionistas e anti-cientificistas, ousou empregar o termo "raça", considerou a violência como resultante da forma como lá se haviam estruturado as relações sociais, desde século XVI, quer dizer, desde a colonização espanhola. Ele escreve, pois, em La raza cósmica:

La obra portentosa iniciada por los férreos conquistadores y consumada por los sabios y abnegados misioneros fue quedando anulada. Una serie de monarcas extranjeros [Habsburgos, de origen alemana] necios de remate 
como Carlos V, el César de oropel; perversos y degenerados como Felipe II; imbéciles como los Carlos de los otros números, tan justicieramente pintados por Velázquez en compañía de enanos, bufones y cortesanos, consumaron el desastre de la administración colonial (VASCONCELOS, 1948, p. 22).

Porém, nessa obra Vasconcelos defende que, se comparados aos ingleses, os espanhóis foram menos violentos - fisicamente, culturalmente - na empreitada colonizadora. Teriam sido, a bem da verdade, a seu ver, mais "amorosos" no tratamento com os nativos. Daí que, sobre o primeiro desses grupos, tenha dito:

el inglés siguió cruzándose sólo con el blanco, y exterminó al indígena; lo sigue exterminando en la sorda lucha económica, más eficaz que la conquista armada"; já sobre o segundo defendeu que, diferentemente, a "abundancia de amor (...) permitió a los españoles crear una raza nueva (...); prodigando la estirpe blanca a través del soldado que engendraba familia indígena y la cultura de Occidente por medio de la doctrina y el ejemplo de los misioneros (Idem, p. 27).

É interessante que, tanto para Vasconcelos como para ensaístas brasileiros como Bomfim, Paulo Prado e Freyre, por meio da comparação que se avalia a condição de bondade, emotividade, passionalidade, brutalidade do latino-americano. Os ditos ensaístas do Brasil da década de 1930, como vimos, fundando para desnaturalizar arraigadas percepções de nosso país como um país bárbaro, comparam a colonização portuguesa, nossa fundadora, com a espanhola. Quanto a Vasconcelos, defendendo tese equivalente, sobre o México, toma como recurso a comparação com os colonizadores ingleses.

Como se pode prever, e já foi vagamente mencionado anteriormente, tal perspectiva perde a força em livros posteriores de Vasconcelos, como Ulises criollo. A narrativa de suas memórias, de suas experiências junto aos líderes revolucionários, é farta em casos de truculência. E ele não os apresenta como característicos apenas da Revolução, ou sobretudo da Revolução traída; eles também se fazem presentes nos primeiros capítulos do livro, que ele dedica ao regime porfirista, vencido. Don Porfírio é descrito como um ditador sanguinário, contra o qual Madero havia lutado, justamente.

Em Ulises criollo, porém, Vasconcelos apresenta Madero como o único líder verdadeiramente revolucionário, em México, porque sobretudo um defensor da paz e da ordem: "El papel que Madero gustava de colocarse, era el de reformador moral por encima del político. Y ya desde el Pan de San Luis, conocedor de su pueblo, le recomendaba que renunciase a la crueldad" (VASCONCELOS, 2000, p. 430).

Caso como Vasconcelos considerou a ação política violenta como não natural mas histórica, relativa e possivelmente justa, desde que ilimitada. Como vimos no capítulo anterior, pouco depois de terminada a Primeira Guerra Mundial, ele fez questão de dizer que a 
brutalidade não seria característica exclusiva dos mexicanos; mas também prática comum aos europeus, que se diziam mais civilizados. Ainda assim, não a desculpou; e farto de tanta desordem e mortes, escreveu:

\begin{abstract}
Algún ingenioso y paciente historiador se ha tomado el trabajo de contar los cuartelazos y revoluciones habidos durante el único siglo que lleva México de ser independiente, y ya llegado a sumar, según creo, 225 actos de insurrección, lo que arroja el gallardo promedio de 2,25 revoluciones por año. Pedir más es gollería (CASO, p. 28).
\end{abstract}

Quanto a Ramos, tal como seus professores ateneístas, defendeu, em El perfil, que a conduta violenta não seria exclusiva do mexicano. E podemos dizer que ele inclusive criticava, no próprio texto de El perfil, a mitificação da selvageria mexicana, como exótica; a seu ver, não haveria nada de "curioso" em ser bruto e assassino: não era interessante, não era vantajoso. Então ele escreveu, em tom irônico: "el México de la leyenda salvaje - que no sé por qué sorprende y atrae tanto a los europeos, que para salvajismos son maestros también, como lo probaron desde 1914 - es un México de exportación, (...) falso" (RAMOS, p. 91).

Tampouco a violência seria inerente ao mexicano, mas resultante de relações sóciohistóricas. Se estabeleceria a partir do agir no mundo, e do pensar sem cuidado sobre esse agir, e comparando-se com outros povos.

A análise de Ramos parte da colonização espanhola para dizer que, desde então o mexicano teria aprendido a ser violento; e que tal comportamento se sedimentou no momento da Independência. Do mal estar ante os fatos de o México ter sido uma colônia dependente, de o México ter se tornado um país livre tardiamente, e, então, ter tido de começar prontamente a competir com nações já bem consolidadas, decorreu, conforme ele, o senso de inferioridade socialmente compartilhado em toda a nação, e constitutivamente entranhado, em cada mexicano. Ora: o mexicano, a seu ver, não "era" violento; mas de passional, e carregando em si um tensionado sentimento de incapacidade, ele se fez um ser cujo comportamento é caracteristicamente violento (Idem, p. 92).

De acordo com a interpretação de Ramos, sentindo-se extremamente vulnerável, impotente, desconfiando de tudo e de todos, o mexicano usaria uma máscara; se apresentaria, cotidianamente, como um homem viril, grosseiro, explosivo (Idem, p. 121). Para usar palavras empregadas por ele no texto de El perfil, e aqui já transcritas nesta Tese, o mexicano se assemelharia a "un animal que se entrega a pantomimas de ferocidad para asustar a los demás, haciéndole creer que es más fuerte y decidido" (Idem, p. 119). Eis aqui a já aludida definição do "pelado". 
O leitor atento se lembrará que Reed já havia abordado tal conceito em seu livro de 1914. E, a bem da verdade, se para o jornalista norte-americano o pelado correspondia, na linguagem popular, ao pobre mexicano que fazia uso de vocabulário e expressões chulas, o mesmo é válido para o autor de El perfil. Cito, pois, trechos do libro de Ramos nos quais isso fica patente: "sus explosiones son verbales, y tienen como tema la afirmación de sí mismo en un lenguaje grosero y agresivo" (Idem, p. 117); "abunda en alusiones sexuales que revelan una obsesión fálica, nacida para considerar el órgano sexual como símbolo de la fuerza masculina" (Idem, p. 120).

Sem pudores, Ramos nos contava, ali, que o mexicano "se consuela con gritar a todo el mundo que tiene 'muchos huevos' (así llama a los testículos)” (Idem, p. 118).

Curioso dar-se conta, então, de que o uso de linguagem grosseira como forma de autoafirmação foi um recurso largamente empregado pelos estridentistas, contra poetas mexicanos ditos vanguardistas, que assumiram outras posturas. Em seu primeiro manifesto, de 1921, Maples insistia em desqualificar a "melancolia" como artifício poético (Apud. MESQUITA, p. 245). E, no segundo manifesto, de 1923, junto a List e Gallardo, proclamava: “Ser estridentista es ser hombre. Sólo los eunucos no estarán con nosotros” (Idem, p. 254).

O pesquisador Rafael Hernández Rodríguez considera que a questão da masculinidade, aventada em El perfil, havia sido de fato central nos debates de contrapuseram estridentistas e os poetas mexicanos companheiros de Ramos, os contemporáneos. Segundo Hernández Rodríguez, não apenas os manifestos mas também poemas de Maples, List, Gallardo, Vela abundam em referências positivas à virilidade, que faziam equivaler a "revolucionário", ativo, forte, masculino, dinâmico, barulhento, "estridente". Por outro lado, estão carregados de alusões negativas ao feminino, à passividade, à assexualidade, que em seus discursos implicariam placidez, sentimentalismo, e reacionarismo (HERNÁNDEZ RODRÍGUEZ, 2002, p. 234).

Tais sugestões se destinavam, segundo o pesquisador supracitado, aos contemporáneos, e sobretudo Salvador Novo, não apenas porque esses, de sua parte, publicavam composições mais subjetivas, e tenderam a ser críticos à Revolução como símbolo, e sim, também, por um motivo mais torpe: porque Novo era homossexual assumido.

Importante pontuar, então, que justamente por mencionar termos chulos em artigo que foi publicado em 1932, em Examen, Ramos acabou por se envolver em uma constrangedora polêmica. Conforme nos conta Juan Hernández Luna, além do texto de Psicoanálises del mexicano, de Ramos, aquele número da revista estampara também capítulos da já citada novela de Ruben Salazar Mallén, denominada Caríatide; capítulos que haviam sido 
compostos na linguagem corrente entre as classes mais pobres do México urbano, de maneira que, também neles, se explorava um vocabulário considerado vulgar (SALAZER MALLÉN, p. 216).

Por aqueles anos, se difundia, ainda, de acordo com Hernández Luna, a notícia de que Narciso Bassols, secretário de instrução pública e fomentador de iniciativas editoriais tais como Examen, desejava tornar obrigatória a disciplina de "educación sexual". O biógrafo de Ramos nos assegura que não era verdadeira tal notícia; mas há tempos ela circulava entre jornais e revistas da Cidade do México, gerando uma tensão tal, que, quando os textos de Ramos e Salazar Mallén vieram a público, fizeram por desatar os ânimos dos leitores mais pudicos (HERNÁNDEZ LUNA, 1982, p. 222).

Ramos, Salazar Mallén e Cuesta, editor de Examen, se viram, então, vítimas de uma enorme campanha da imprensa capitalina, que resultou num processo judicial: os três foram acusados de "delito de ultraje a la moral". Terminaram por ser, efetivamente, inocentados, mas foram destituídos de seus cargos públicos, e a revista acabou fechada, afinal (Idem, p. $217,223)$.

Por isso, no capítulo de $\mathrm{El}$ perfil que recebeu o mesmo nome do dito artigo Psicoanálises del mexicano -, há menção indireta à polemica, quando se justifica a opção por descrever minuciosamente a fala do mexicano comum: "Sería imperdonable que prescindiera de um valioso material de estudio por ceder a una mal entendida decéncia de lenguaje" (RAMOS, p. 120).

Ora, não é curioso que alguns dos mexicanos fossem admirados como fortes e capazes pelas posturas violentas, grosseiras e pelo uso de vocabulário chulo, enquanto outros eram justamente punidos por recorrerem a isso, criticamente ou ironicamente? E que justamente os autores citados por Bartra como "responsáveis" pela imagem acrítica do referencial de mexicano, de referencial revolucionário, fossem aqueles que criticassem a exotização da violência e dos modos grosseiros dos mexicanos do campo e da cidade?

Convém, ainda, voltarmo-nos a outras características importantes do "pelado", de Ramos. Por exemplo, ao fato de que, ao ver desse ensaísta, tal como ao ver de Guzmán, em La sombra del caudillo, o mexicano seria hermético.

Essa é uma ideia, aliás, retomada, ainda, por Octavio Paz, em seu Laberinto de la soledad (1950). Para Paz também, nesse livro, a insegurança geraria, em México, indivíduos ressabiados, e falseadores: "a mentira tem uma importância decisiva em nossa vida cotidiana, na política, no amor, na amizade. [Entretanto,] com ela não pretendemos absolutamente 
enganar os outros, mas sim a nós mesmos” (PAZ, p. 39-40); “[O mexicano] está condenado a representar a vida inteira" (Idem, p. 41).

Para Paz, em verdade, o mexicano, buscando preservar-se, poderia revelar-se tanto "cortês" como "espinhoso", tanto gentil e hospitaleiro como negligente, conversador ou quieto, resignado ou irônico, vítima ou colérico (Idem, p. 30). E efetivamente Guzmán e Ramos também consideraram essas diversas possibilidades, em seus textos - os personagens da novela de Guzmán têm um jeito de sorrir muito próprio e rico em significados, e o burguês mexicano, definido por Ramos, se caracterizaria por disfarçar sua ira com uma fala pomposa. Entretanto, esses dois últimos autores consideraram sobretudo a aparente necessidade de o mexicano "fechar-se" em comportamentos violentos; e concentraram-se em condenar isso.

Paz, diferentemente, parece mesmo sugerir - como pontua Bartra - que a Revolução Mexicana correspondeu a uma "explosão de espontaneidade", uma "vingança" contra essas regras tão estreitas que oprimiam o ser mexicano; que o "mutilavam"; que o condenavam à não-satisfação de "apetites tão vitais", que o cerravam na estreiteza de uma mentira limitadora (Idem, p. 33).

Pode-se especular que Guzmán, tal como Paz, apresentara uma versão colorida da violência revolucionária; afinal, um dos capítulos mais célebre de El águila y la serpiente leva o título Fiesta de las balas. Mas, note o leitor, esse capítulo não recebeu destaque pelo autor, e sim pelas gerações que o leram, e o consideraram relevantes, por tal e qual motivo que, de certa maneira prescindem dos propósitos daquele que o concebeu. No contexto da obra completa, afinal, esse trecho me parece se somar a um entendimento da Revolução como uma tragédia cotidiana, forte, dolorida, a se superar, e não a endossar, a se aceitar.

É uma visão diferente, por exemplo, de outro contemporâneo dos ateneístas, nesta Tese citado mais de uma vez: Manuel Gamio, autor de Forjando pátria (1916). Em sua crítica, Bartra chega a citá-lo nada mais que uma ou duas vezes, sem concentrar-se em suas proposições. Mas ele sim apresentara, com todas as letras, em sua obra, a convicção de que o processo revolucionário deve ser comemorado, aceito, e desdobrado, tal como é, tal como tem de ser. Nas linhas desse livro, propriamente, lemos a seguinte metáfora, sobre a Revolução: "Si de una montaña caen torrentes que inundan nuestras habitaciones o nuestros campos, no sería cuerdo pretender destruir el torrente ni la montaña, sino que se les aprovecha; se encauza el agua y se hiende y se perfora la montaña, obteniéndose fuerza motriz, que es uno de los factores del bienestar humano" (GAMIO, p. 301).

Pode-se especular, então, que Ramos, tal como Paz, postulara, em El perfil, que, oprimidos ao longo de séculos, os mexicanos, por fim, ao chegar o século $\mathrm{XX}$, se teriam 
convertido em brutos e, em última instância, justos combatentes. Contudo, considero tal tese difícil de se sustentar. Como tenho dito, na análise de Ramos a Revolução não revelava, por si só, um mexicano completamente novo; a Revolução era expressão exacerbada, era desdobramento inesperado de - note bem - comportamentos antigos, práticas rotineiras (RAMOS, p. 140).

Assim, diferentemente de Reed, Gamio e Paz, e junto a Vasconcelos e Caso, tal autor não parece compreender a brutalidade revolucionária como "mal necessário" ou como "força vital"; ele a considera como fato importantíssimo, mas que deve ser mais e mais criticado, até que se viabilizem, a partir dessa crítica, algumas transformações fundamentais que a Revolução em si, como processo violento, não inclui e não pode incluir.

Eu diria, assim, que, no texto de El perfil, se a passionalidade mexicana é perdoada e de alguma maneira consentida; a violência, repetida, é absolutamente condenada. Porque a passionalidade, conforme o entendimento de Ramos, pode servir de base para a elaboração de projetos que rompam com a aleatoriedade dos costumes políticos, em México. E a brutalidade, a rusticidade, não.

Aqui podemos nos remeter aos companheiros de jornada de Ramos, os contemporáneos, que, em El laberinto de la soledad, aparecem como poetas preocupados com a temática da morte. Nesse livro Paz lembra a intenção de Gorostiza e Villaurrutia de pensar filosoficamente tal tema, naqueles que Paz reconhece como seus livros mais interessantes: respectivamente, e Muerte sin fin, de 1939, e Nostalgia de la muerte, 1938 (PAZ, p. 58-59).

Paz defende que ambos compartilham, assim como todo mexicano, um sentido da morte como presente, e anseio; e não como fim. De maneira que, para ele, aqueles versos compostos no início do século XX endossam a ideia de uma Revolução necessária; ou da Revolução como "mexicana” (como algo característico do, ou que caracteriza o mexicano).

Parece-me que, nesse ponto, a interpretação de Paz, acerca de Novo e Villaurrutia, se afasta da minha acerca de Ramos, porque eles não perceberiam, para Paz, o processo revolucionário como culminação de problemas que deveriam ser enfrentados, e prontamente solucionados; eles não temeriam a morte como Ramos me parece ter temido. Contudo, as interpretações contidas em El laberinto de la soledad, sobre os contemporáneos, têm sido vastamente criticadas.

Ao ver de Anthony Staton, por exemplo, a interpretação de Paz parece descabida, porque impõe aos contemporáneos uma dimensão que eles declaradamente descartavam. Como vimos no segundo Capítulo desta Tese, Novo e Villaurrutia simplesmente não se pensavam, nem se propunham ou desejavam ser vistos como poetas mexicanos, e sim como 
poetas universais - "Villaurrutia y sus compañeros deben haber recibido con asombro esta contextualización cultural de una poesía que se concebía independiente de cualquier geografía cultural o cualquier tiempo histórico" (STANTON, p. 1007). A morte à qual se referem é, assim, tanto a vivência do combatente revolucionário mexicano, ou russo; do falido empresário estadunidense, vítima da crise; da mãe francesa/ inglesa/ alemã, que vê seu filho partir para a guerra; do negro brasileiro do campo ou da cidade.

Eu diria, portanto, que tal como Maples rotula e reduz os contemporáneos a condição de "femininos", "europeizados" e "anti-revolucionários", Paz os classifica e simplifica, quando os concebe como "amigos/amantes da morte", "mexicanos" e... "revolucionários". A meu ver, Ramos e seus companheiros editores e colaboradores da revista Contemporáneos devem ser lembrados, então, também, como se desenharam, como se perceberam, como se propuseram: sensíveis, mas fiéis a suas maneiras de enxergar o local, inovadores e humanos.

No que tange os intelectuais brasileiros daqueles tempos, ainda que destacassem a passionalidade como característica de nosso povo, tampouco deixaram de considerar nossos comportamentos e hábitos violentos. Isso é bastante notável inclusive (e talvez sobretudo) nos ensaístas que tomei para análise nesta Tese.

Isso porque os argumentos de Paulo Prado e Bomfim, na defesa do portuguêsfundador como colonizador mais dócil, são, efetivamente, pouco convincentes, quando confrontados com o todo de suas reflexões, respectivamente em Retrado do Brasil e América Latina: males de origem. O primeiro desses escritores considerou, por exemplo, como "aspecto [que] diferencia essas entradas [as portuguesas, ou mais, especificamente, paulistas] da conquista violenta que ensanguenta a crônica dos invasores castelhanos" o fato de que o "ímpeto guerreiro dos sertanistas se limitava à escravização do aborígene rebelde, desde que não o pudesse seduzir para o trabalho da sua lavoura" (PRADO, 2001, p. 98). Lhe parecia um ato menos agressivo, mais suave, escravizar e explorar?

Quanto a Bomfim, embora defendesse que os portugueses não foram tão vorazes e violentos quanto os espanhóis, também dificultou, por parte de nós, leitores, a concepção de um grau maior de voracidade e violência, a se atribuir aos hispânicos, se descreve os lusitanos como "homens práticos", para os quais não convinha "perder tempo em desatarrachar os brincos das mulheres, quando é tão simples contar-lhes as orelhas" (BOMFIM, p. 101).

Ademais, deve-se ter em mente que uma das afirmações mais incisivas de Bomfim, em seu primeiro ensaio, é a de que o individualismo e a violência teriam percorrido todo tipo de relações, em toda América Colonial: “as populações nascem assim desunidas; crescem, e crescem com elas os ódios. A vida é um conflito permanente, uma luta desordenada, com 
episódios de violência e barbaria, de crueldade bestial, de perversidade torpe. A luta começou no dia em que o primeiro aventureiro pisou na América, e ainda não cessou" (Idem, p. 166). No Brasil, do parasitismo teria surgido, pois, uma "população mesclada, embrutecida" (Idem, 167).

Para esse autor, por fim, as dimensões mais apreciáveis do afeto, entre nós, brasileiro e hispano-americanos de hoje, haviam sido historicamente mal trabalhadas: "E o sentimento? E a moralidade? Como se poderão desenvolver e apurar os sentimentos altruísticos, de justiça e equidade, de cordialidade e amor, numa sociedade que sucede viver, justamente, de uma iniquidade?" (Idem, p. 66-67).

Mesmo Freyre, no prefácio tantas vezes reformulado de Sobrados \& mucambos declarou, pontualmente: “a situação não era idílica” (FREYRE, 2004, p. 29). Eis um argumento que o próprio Leite, em sua severa crítica, também vislumbra, quando indica:

os títulos dados às suas obras principais (...) indicam até que ponto Gilberto Freyre compreende a história brasileira como resultante do trabalho de dois grupos antagônicos, (...) de forma que ultrapassava a parcialidade dos que viam o Brasil como obra de alguns homens notáveis do Império de da República (LEITE, 2007, p. 375).

Haveria, pois, ao ver de Freyre, mais do que uma simples docilidade, tipicamente nacional, um eixo aparentemente paradoxal, percorrendo em nosso modo de ser brasileiro, e articulando querer e violentar - para tal ensaísta brasileiro, ambas as coisas, no homem do Brasil, apareceriam intimamente e vivamente juntas; nossa civilização se teria formado considerando a proximidade, mas também, numa mesma medida, a brutalidade (FREYRE, 2001, p. 123).

Freyre falava, porém, não em uma amorosidade constitutiva; mas com o fato de que o tratamento arbitrário que o brasileiro comum recebia de seus superiores amaciava os modos: "o mando desenvolve nos senhores vozes altas e nos servos falas brandas e até macias quase sempre acompanhadas de sorrisos também doces"; "modos agradáveis que vinham do desejo dos servos de se insinuarem à simpatia, quando não ao amor, dos senhores" (FREYRE, 2004, p. 743). Haveria no Brasil tipos, assim, "ruins ou safados, é verdade, mas muito simpáticos" (Idem, p. 790); a que Freyre chamava, significativamente, circunstancialmente, "cordialidade".

Note que aqui Freyre trabalhava com uma mesma linha de raciocínio que Guzmán: a de que a brutalidade era, senão mais característica da elite, de certa maneira responsabilidade dela. O mesmo não é válido completamente para Ramos, que compreendia a ação violenta, embora decorrente de relações históricas, como apreciável em todos os estratos sociais, no 
México. Tampouco é válido para Holanda, que definiu como referência de comportamento, para a elite, não ser ríspido, mas amoroso.

Todavia, é preciso estar aqui atento. Conforme demonstrado no primeiro Capítulo desta Tese, embora tenha sido corrente a impressão de que, nesse sentido, os argumentos de Holanda resultavam na ideia do "homem cordial" como simples bom anfitrião, sorridente e benfazejo; tal apreciação é, hoje, muito pelo contrário, bastante questionada. Prevalecem, assim, os estudos que apontam a mesma articulação, presente em Freyre, entre afeto e violência, no vértice do qual descenderiam as práticas de cordialidade.

Paulo Niccoli Ramirez insiste, entretanto, que, enquanto Freyre pretendia apontar que toda ação violenta, no Brasil, desde a colonização, possuía uma nota de afabilidade, de intimidade, de sensualidade; Holanda se esforçou por demonstrar como as relações afetivas escondiam seus fundamentos de brutalidade (RAMIREZ, 2011, p. 140-141).

Para Lilia Moritz Schwarcz o "homem cordial” de Raízes se caracterizava por certa "polidez coercitiva"; e, enquanto ferramenta analítica, viabilizada a denúncia do Brasil como uma nação falsamente harmônica, como uma nação na qual a todo tempo vislumbram-se esforços por encobrir a relação violenta entre dominador e dominado (SCHWARCZ, 2008, p. 86).

A observação positivo-negativa de atos violentos se deu também entre muitos dos modernistas. Em Oswald, na já clássica metáfora da antropofagia, da devoração do inimigo, transformou uma ação brutal em ícone referencial não apenas de Literatura, mas de uma Literatura nacional - como Bartra criticou, a muitos dos escritores mexicanos.

Mas antes disso, Oswald publicara versos nos quais explorava não apenas a gramática do brasileiro comum como a forma de organizar ideias; nos quais se inspirava em "causos" da gente pobre, e que volta e meia consideravam como tema as violências e dores cotidianas. Um bom exemplo é Medo da senhora, de Pau-brasil (1924): “A escrava pegou a filhinha nascida/ Nas costas/ E se atirou no Paraíba/ Para que a criança não fosse judiada" (ANDRADE, 2003, p. 126).

E também Mario, que como vimos exaltou, em meados da década de 1920, o amor como amálgama social, no Brasil, passa a explorar das lendas e causos populares brasileiros essa temática da violência cotidiana. Na composição de seu personagem mais famoso, o Macunaíma, fala, pois, de um tipo preguiçoso, oportunista, malandro, enganador, que agride a mãe e a mulher amada, Ci; e é também, da família e na cidade grande, vítima da violência; e, no regresso à casa, à aldeia, vítima da perda de referenciais - quando retorna, o lar foi dizimado (ANDRADE, 1970). 
Manuel Bandeira, que vim propondo como um literato que teria apresentado um ponto de vista acerca da função social dos intelectuais mais próximos do de Holanda, entre as décadas de 1930, se celebrizou, afinal, por versos nos quais rotulava como "tão Brasil" o carnaval, evento no qual opostos convivem se entorpecendo e dançando, e até invertem os papéis; a festa, que simboliza a opção nacional por esquecer os problemas e/ou as possibilidades de crescimento, e tão somente sorrir e estar junto - trata-se do poema Não sei dançar, de Libertinagem (1930).

Para concluir, podemos sugerir uma ideia geral, que percorre tanto a análise de Holanda quanto a de Bandeira e de Ramos, em seus escritos tão célebres: o homem cordial, o brasileiro, o pelado, elaborados como referencial para se pensar os cidadãos do Brasil e do México contemporâneos, não eram, em si, para eles, necessariamente emotivos e irracionais. Eram, na escrita de Holanda, Bandeira e de Ramos, personagens/conceitos caracterizados por um fundo emocional bastante complexo, e a respeito do qual revelavam parco conhecimento, consciência, aceitação; ou que teriam recalcado, ofuscado, para manterem-se em uma zona de conforto que repercutia em caos social e parco desenvolvimento. Mais do que considerarem interessante pensar sobre um afeto transbordante, uma alegria natural, ou um ódio cego pelo outro, respectivamente, esses autores desejavam compreender o que haveria de inconsciente nas sociedades brasileira e mexicana, de princípios do século XX. Holanda e Ramos, ao menos, o fizeram sob influência da psicanálise.

Aqui se desvela, logo, um último ponto importante: se poderia supor que o "homem cordial" de Holanda era bastante diverso do "pelado", de Ramos: enquanto um se caracterizaria pela afetividade, o outro se caracterizaria pela brutalidade. Considero, porém, a partir dos argumentos até aqui apresentados, tal perspectiva equivocada: primeiro, porque, como temos visto neste Capítulo, o pelado mexicano, de El perfil, teria herdado certa passionalidade ibérica; depois, porque a "cordialidade", definida em Raízes, temos acompanhado, poderia incluir reações e ações violentas. 


\subsection{Pensar e estruturar intelectualmente a transformação sociopolítica}

A tese de uma história nacional, brasileira ou mexicana, revolucionária ou não efetivamente revolucionária, como um movimento espontâneo, e caracterizado pela violência, não implica, porém, na percepção dos processos como alheios em tudo a qualquer conjunto mais ou menos articulado de ideias. Na realidade, como temos acompanhado, ao longo das três décadas às quais me dedico nesta Tese - 1910 a 1930 - muitos projetos de nação foram concebidos, e serviram de base para garantir a implementação de determinadas medidas e/ou leis; ou ainda legitimar o poder de determinados chefes, no Brasil como no México.

Cabe, por ora, compreender como as proposições apresentadas em Raízes e El perfil sobre as ideias ditas pelos governos instituídos, então, revolucionárias dialogam com outras fundamentais proposições, apresentadas, à época. Aqui avalio, assim, como diversos autores do período, dentre os quais Holanda e Ramos, perceberam tais ideias: suas dimensões, aplicabilidade e originalidade.

No caso do Brasil, temos que as alterações político-institucionais promovidas no início do século XX denominadas "revolucionárias" - ou, mais precisamente, a Revolução 1930 não contaram com considerável envolvimento de populares, tal como no caso do México. E que isso provavelmente repercutiu diretamente na escrita de Holanda e Ramos: conforme acompanhamos no terceiro Capítulo desta Tese, a questão da aleatoriedade ganhou dimensões sutilmente distintas, por parte de um e outro autor: o primeiro focou a crítica na limitação de alterações institucionais que são rotuladas "revolucionárias", e o segundo focou a amplidão de possibilidades (boas ou nem tanto) que se podem desdobrar em países marcados por experiências ditas "revolucionárias".

Bolivar Lamounier, avaliando as mudanças econômicas observáveis quando da Revolução de 1930, assim como a política econômica de Vargas, afirma que teriam sido "inicialmente reflexas, poder-se-ia mesmo dizer instintivas". Porém, pondera que "foram aos poucos assumidas como visão doutrinária, ou seja, como um modelo de industrialização": as novidades institucionais foram vistas como programa de desenvolvimento (LAMOUNIER, $\mathrm{p}$. 42).

Vargas chegou ao poder em 1930, suspendendo a Constituição em vigor desde 1891. Por pressão do estado de São Paulo, num movimento armado que recebeu a denominação de "Revolução Constitucionalista", uma lei foi redigida e promulgada - era o ano de 1934.

O novo texto apontou algumas diretrizes de atuação política não apenas no âmbito econômico - focado por Lamounier -, mas também social. Propôs, por exemplo, o Estado 
como promotor do desenvolvimento econômico; o que seria cumprido nos próximos anos seguintes. Mas também a nacionalização de bancos e minas, e a concessão, pelos governos, de uma série de benefícios sociais para as classes mais baixas; o que Vargas considerava financeiramente inviável.

A nova Constituição, ademais, reforçou o federalismo, ponto que nunca chegou a ser efetivamente praticado, já que Vargas concentrou todo o poder em suas mãos; até legitimar tal procedimento, um ano após Holanda publicar Raízes, instituindo "estado de sítio" - o chamado "Estado Novo" -, e outorgando uma nova carta de lei, com fortes bases anticomunistas e ditatoriais.

As bases teóricas da Norma promulgada em 1934 têm sido consideradas um tanto ambíguas: conforme Marcos Arruda e Cesar Caldeira, o mesmo tempo em que elogiadas pelo caráter progressista, e por remeter a algumas ideias claramente socialistas, foram criticadas por dialogarem com muitos dos princípios presentes na constituição alemã, estabelecida por Hitler (ARRUDA; CALDEIRA, 1986). Daí Vargas ter afirmado, em 1940, que ela, "acenando a ideologias exóticas", estaria "divorciada das realidades existentes" (Apud. Idem, p. 176).

A partir do golpe que abriu a década de 1930, no Brasil, houve também mudanças no âmbito das políticas culturais, embora Holanda as tenha ignorado no texto de Raízes. Vargas investiu sistematicamente em educação, produção e circulação de bens culturais; isso vinha responder a demandas específicas de nosso país e daquele tempo, e ao mesmo tempo exigia e correspondia à formulação de conjuntos de ideias mais complexos; programas, projetos, ideologias. Veremos, adiante e oportunamente, as propostas de Vargas e seus assessores, sobretudo o ministro Gustavo Capanema, e outros intelectuais dissidentes ou não, para a educação nacional, e como Holanda se posicionou ante elas

Na expressão de Luiz Guilherme Piva, Holanda foi, em Raízes, um "ensaísta ladrilhador" e não semeador, porque propôs uma "empresa da razão contra a ordem natural, ou contra a ordem vigente" (PIVA, 2000, p. 10). Em outras palavras, para Piva Holanda teria apontado a espontaneidade brasileira, o desleixo, como problema; e a racionalização, base da civilidade, algo a ser incorporado (Idem, 156).

Antonio Arnoni Prado lembra, por outro lado que, tal como os modernistas, Holanda justamente valorizou o aspecto espontâneo da população pobre do Brasil, em contraste como o comportamento tipicamente artificial de nossas elites. A seu ver, para parte dos intelectuais ligados ao modernismo a confusão do mestiço, do matuto, do trabalhador braçal seria tão responsável por nossa anarquia política e subdesenvolvimento político, quanto o falso ordenamento, importado, pelas classes mais ricas. Porém, entre a gente simples haveria uma 
nota distoante, capaz de alterar nossa rota histórica, e promover transformação, e maior justiça social - nota que Arnoni Prado chama "refinamento selvagem" (PRADO, 2006, p. 301).

Porém, devemos considerar que essas duas variáveis - o interesse pela racionalidade estrangeira e pela espontaneidade nacional - são se excluem. Como modernista, diz Piva, Holanda consideraria que a questão era "nacionalizar o elemento externo, melhorando-o"; consideraria que "o elemento puramente racional é vital, mas não pode ser a-histórico e despegado da vida real, erro cometido pelos políticos com seus programas e plataformas supostamente infalíveis" (Idem, p. 156 e 184).

Ao ver de Ramirez, Holanda desejava justamente que realidade e pensamento se “reconciliassem” (RAMIREZ, 2011, p. 174).

Nisso, talvez, Holanda se aproximasse de Ramos, que sonhava com intelectuais ao mesmo tempo vividos, conhecedores das dinâmicas sociais mexicanas; e eruditos, conhecedores das ciências e das literaturas universais. Mas, como pontuei anteriormente, nesta Tese, o autor de $\mathrm{El}$ perfil parece ter-se interessado de forma bastante mais clara por definições mais acertadas, por parte dos intelectuais - no âmbito educacional e mais - do que o autor de Raízes. Para o ensaísta mexicano a ação aleatória da massa popular parecia incomodar um tanto mais; para o ensaísta mexicano os intelectuais deveriam sim assumir um papel não apenas crítico, mas, também, direto, sistemático, construtor.

Antes de mais vejamos, pois, o que propuseram a respeito outros escritores mexicanos, interessados no tema da revolução.

Gamio, em Forjando pátria, propôs de que a Revolução correspondera a um momento real, dinâmico, necessário, geral, cuja lógica aparentemente irracional deveria ser respeitada; cuja lógica - sim, porque haveria, em última instância, para esse autor, uma certa lógica na Revolução - deveria ser sentida, intuída e cumprida pelos intelectuais, como homens de ação. Ele escreveu: "hay que considerar a la Revolución, como un acontecimiento natural, enteramente natural; hay que marchar con ella y no contra ella. Oponer obstáculos a su carrera, es tanto como empeñarse en inmovilizar el mar u obscurecer el día” (GAMIO, p. $303)$.

Reed, em seus registros sobre as primeiras movimentações revolucionárias no México, pareceu defender que elas realmente não partiam de qualquer elaboração intelectual formal. Ele afirmou, por exemplo, que Villa ignorava os conceitos de "democracia representativa", "voto universal" e "socialismo" (REED, p. 166). Mas para o autor de México insurgente isso não significava que Villa não tivesse ideias claras sobre como proceder. Entretanto, suas ideias partiam de uma percepção instintiva acerca da coletividade, e de uma vivência prática 
das necessidades. Reed escreveu, assim, que "Villa [era] um peão, que pensa[va] como tal, e mais do que se pôr a raciocinar conscientemente (...) agiu com presteza característica e sem rodeios" (Idem, p. 172).

A visão de Guzmán, acerca de Villa, apresentada em El águila y la serpiente, é bastante distinta da de Reed. Guzmán desenha, para o líder revolucionário, um perfil infantilizado; ora iracundo, ora amável; e isso o leva à desconfiança - o autor declara que, a todo tempo, em contato com Villa, teria mantido uma postura de distanciamento e receio. Dessa instabilidade e da tendência à crueldade, ao roubo, e ao desrespeito em relação às normas, Guzmán concluiu, a respeito de Villa, que não poderia corresponder a uma referência de proceder, para o México que sonhava com transformação radical (GUZMÁN, 1941, p. 76).

No texto de Los de abajo, Azuela parece repetir a ideia de que, embora não possamos falar em pressupostos filosóficos, formais, que norteassem a Revolução nos seus primeiros anos, houve uma percepção instintiva, por parte dos combatentes, no que diz respeito a um projeto transformador coletivo; que se ia elaborando na prática.

Conta-se, em Los de abajo, que Demétrio, o general protagonista, ingressara nas fileiras revolucionárias por um desentendimento bem específico com um rico fazendeiro de sua cidade de origem; quer dizer, por um motivo particular e ocasional (AZUELA: 46). Porém, há um personagem que faz contraponto a tal percepção; trata-se de Luis Cervantes, alterego de Azuela, médico intelectualizado que se soma ao bando, e afirma que aquela seria uma meia verdade, fruto de um olhar descuidado. Na concepção de Cervantes, Demetrio não lutaria contra "Don Mónico, el cacique" e sim contra "el caciquismo que asola toda la nación" (AZUELA, p. 49).

Efetivamente, em Los de abajo, Cervantes é o único personagem que entende a Revolução como um movimento de transformação da realidade nacional, para o bem de todos. E esse entendimento decorre, em grande parte, de ser ele um homem mais lido do que os demais; por dispor ele de um maior capital conceitual e reflexivo.

Quanto a isso, a composição de Azuela é ambígua. Por um lado, Cervantes é apresentado como um idealista, que sofre ao deparar-se com a realidade dos interesses individuais e imediatistas dos revolucionários; e o fato é que, ele próprio, acaba por abandonar a luta por questões particulares não muito bem esclarecidas. Por outro lado, contudo, Cervantes e o leitor podem encontrar na população comum, cuja voz figura aqui e ali em Los de abajo, a confirmação de que a Revolução expressa um sentido coletivo, que cabe ser sistematizado, mas que de certa forma já aparece implícito no pragmático pensamento dos líderes combatentes. 
Octavio Paz, anos mais tarde, repetiria a tese da ausência de um sistema de ideias revolucionário; e, de que, ao longo daqueles anos, se deu a conformação de um repertório de ideias mais ou menos coerente. Um repertório estabelecido no calor das batalhas. Escreveu, então, em Labirinto de la soledad: "Daí provém sua grandeza e suas fraquezas. (...) Lentamente, em plena luta (...), o movimento se encontra e se define.” (PAZ, p. 123).

Leopoldo Zea, contemporâneo de Paz, apresentou também tal duplo raciocínio aleatoriedade permeada de algum sentido capturável, seguida de prática de elaboração. Cito-o: "Primero fue la realidad puesta a flote por la violencia revolucionaria, después vino su inspiración y reflexión. Casi a ciegas, tanteando y acariciando una realidad que se presentaba con toda su fuerza sin aviso alguno, nuestros políticos, pensadores y artistas fueron dibujando sus perfiles" (ZEA, p. 29).

Senão, vejamos como as noções de experiência, prática, e ideias se deram e articularam nos debates que envolveram a composição da constituição dita "revolucionários", no México da década de 1910.

Segundo Sussarrey, a Constituição mexicana do período da Reforma, do ano de 1857, seria essencialmente liberal, por partir de uma concepção de indivíduo bastante moderna. Nesse sentido, então, para esse historiador, a carta promulgada em 1917 corresponderia a um "retrocesso", por dois motivos. Primeiro, porque teria um transfundo barroco, arcaico: partiria de uma concepção de Estado bem próxima à do Estado espanhol colonizador; de Estado como "propietário original de tierras" (SUSSARREY, 2010). Segundo, porque seria base de legitimação da livre ação de certo grupo social, travestido em burocracia, ou travestido em Estado, que a bem da verdade daí em diante logrou lidar com os bens nacionais conforme seus interesses específicos, em seu próprio proveito, arbitrariamente, reacionariamente.

Para Sussarrey, enfim, a Constituição de 1917 é um "recetario de promesas, que van desde el derecho a la vivienda hasta el derecho a la felicidad absoluta” (Ibidem).

Lorenzo Meyer, diferentemente, argumenta que a Constituição de 1917 não teve nada de utópica; foi estruturada - a seu ver, de maneira bastante interessante - a partir da realidade específica, local, para que se viabilizassem transformações condizentes com os anseios propriamente mexicanos, do momento. E se forjou como pretenso ponto de partida para uma sociedade democrática e autêntica. O tema da terra, que não apareceu na constituição "revolucionária" brasileira, composta dezessete anos depois, recebeu ênfase dos constituintes porque fora uma das exigências dos populares envolvidos nas contendas, desde pelo menos 1910 (MEYER, 1987). 
Gloria Villegas considera, ainda, o pensamento que com o tempo passou a embasar a chamada Revolução Mexicana, e que se fez notável no texto da Constituição, como bastante avançado, inclusive se comparado ao que se verifica como projeto político em outros países, naquele momento, ao redor do mundo. Ora, a Constituição de 1917 e o grupo que se estabelece no país a partir de 1917, ao ver dessa autora, teria amplo apelo social; ao passo que na Europa estavam em difusão, conta o liberalismo em crise, os ideais totalitaristas (Apud. MIJANGOS DÍAZ, p. 157). Como vimos há pouco, no Brasil muitas dessas questões só passariam a ser vastamente consideradas em programas políticos a partir da década de 1930.

Todavia, Villegas também apresenta críticas ao trabalho dos constituintes mexicanos de 1917. Eles teriam optado pelo modelo presidencialista como uma maneira de aplacar as diferenciações de interesses, de necessidades, de região para região, de grupo para grupo, tão características do México. Assim, diz a autora, derrotaram a proposta inicial de Madero e dos "convencionalistas", quer dizer, o parlamentarismo; e assim, a seu ver, lamentavelmente, acabaram por impossibilitar a incorporação das diferenças tensionadas, em um jogo complexo e mais plural (Ibidem).

É verdade que Ramos não apresenta, em El perfil, uma análise especificamente da Constituição Revolucionária. Mas ele se refere ao texto constitucional de 1857, e seus argumentos a respeito talvez nos permitam especular sobre a visão que possuía sobre o de 1917.

Em suas reflexões, Ramos considera, por acaso, o mesmo problema que a professora Gloria Villegas, quer dizer, a diversidade étnica, geográfica e social, que caracterizava o México; e pontua que, por causa disso, a opção, nos oitocentos, pelo federalismo, tinha sido um erro. E não que considerasse que, constando como filosofia do regime, os mexicanos tiveram de cumpri-la, prejudicando-se; e sim, simplesmente, porque tal ideia jamais chegou a ser cumprida. "La realidad, superior (...), obligaba a los gobiernos (...) a imponer un centralismo disimulado, para mantener cierta unidad en medio a la anarquía reinante", escreveu em El perfil (RAMOS, p. 99).

Considerando que a Constituição de 1917, ademais de celebrar o presidencialismo, replicou o federalismo liberal, podemos supor que Ramos, nas entrelinhas de El perfil, a criticava indiretamente? É possível. Contudo, creio que ele o faria num mesmo tom, acima aludido: não denunciando que o cumprimento das ideias propostas no texto constitucional teria representado uma violência (tal como sugere Villegas); e sim denunciando que não havia formas de efetivamente viver esses ideais, que esses ideais simplesmente não foram cumpridos. 
A despeito da Constituição revolucionária ser uma das mais avançadas do planeta com robustos fundamentos liberais e preocupações sociais -, o México, afinal, em 1934, quando Ramos escreve El perfil, continuava sendo um país oficialmente federalista, continuava sendo um país na prática cravado de tensões, incrustado de diversidade, e no qual a força do Caudillo-presidente, do Jefe Máximo, prevalecia.

Do que podemos concluir que Ramos, em El perfil, propôs um raciocínio um tanto distinto de Paz e Zea. Para ele, o mexicano pretendia se apresentar em geral como um homem prático; porém, apenas o era no sentido de quem age conforme as circunstâncias, de forma imediatista e reativa; não no sentido de quem, a partir de certo entendimento/conhecimento acerca de suas condições e necessidades, atua visando transformar e criar (RAMOS, p. 122$123)$.

Em Ramos, como em Holanda, houve, pois, o interesse por pensar modos específicos de agir; daí que Ramos tenha feito constar, em El perfil: "Si algo tenemos que lamentar de nuestra historia, (...) de nuestros antepasados (...), [es] no haber sido ellos mismos, sinceramente, con sus cualidades y defectos" (Idem, p. 102).

Ramos percebia a Revolução como o despertar de uma nova era; mas lamentava que por aquelas décadas de conflitos os homens necessários para a constituição e solidificação de um ponto de partida, de um referencial de pensamento - quer dizer, de uma Filosofia própria, autêntica, nacional, crítica e independente - estivessem envolvidos em questões bélicas e políticas urgentes/imediatistas, e não possuíssem o tempo de ócio necessário para pensar as práticas mais comuns em México, formas de superar algumas, e de aprimorar outras (Idem, p. 99).

O caos social e a falta de regularidade na formação dos pensadores mexicanos incorriam, a seu ver, na dificuldade de se refletir profundamente, radicalmente, e de uma forma verdadeiramente própria, no México; repercutiria na estruturação de referenciais falsos, inaplicáveis.

Aqui cabe, pois, um parêntese em que se cruzem as reflexões de Ramos e Gamio; porque, nesse aspecto, elas se aproximam consideravelmente.

Gamio acreditava, como acima pontuei, que as sociedades cumpriam, em seu devir, cada qual, um ritmo próprio, que deveria ser respeitado por aqueles que pensavam acerca delas, e se dedicavam a propor projetos de transformação para elas. Porém, compreendia, tal como Ramos, que, historicamente, e agora, na modernidade, isso não vinha ocorrendo, em seu país. 
Gamio defendeu, pois, em Forjando pátria, de uma forma que se aproxima muito de Ramos e os diagnósticos de El perfil, que o México se caracterizava por um grande corte a separar realidade e ideologias políticas oficiais; uma grande disparidade entre o que os governos propunham e o que os mexicanos viviam, na prática. Escreveu:

Se dice que el sistema de gobierno que generalmente ha regido a México independiente fue el democrático representativo, pero en realidad no sucede así porque las clases indígenas han sido forzadas a vivir bajo el gobierno de leyes que no se derivan de sus necesidades sino de las de la población de origen europeo, que son muy distintas (GAMIO: 16).

Mas o fato é que Ramos não identificou, em seu célebre ensaio, da década de 1930, as contribuições de Gamio, que já era um escritor relativamente conhecido no México e no estrangeiro desde meados dos anos 1910. Ramos não mencionou o nome de Gamio, quando criticou o anseio, por parte de muitos dos intelectuais mexicanos, seus contemporâneos, de se "forjar" um mexicano; e tampouco quando propôs ideias semelhantes às de Gamio, como o anseio por uma ideologia, uma antropologia, um pensamento, uma filosofia própria, mexicana.

Como apontei capítulos anteriores, os pensadores que Ramos considerou, textualmente, estarem desenvolvendo um trabalho de qualidade, inovador, no México, foram os ateneístas. E seu elogio voltou o foco, especificamente, para o fato de que teriam sido, a seu ver, pioneiros nessa intenção_de trabalhar perspectivas mais próprias.

Pode-se supor que o raciocínio Gamio de certa maneira se aproxima das reflexões de Holanda, em Raízes: diferente de Ramos, ambos valorizaram o jogo espontâneo das dinâmicas históricas nacionais; e propuseram que os intelectuais deveriam se concentrar nesse modo de ser, respectivamente, mexicano e brasileiro. Entretanto, não podemos perder de vista que Holanda foi bastante mais receoso do que Gamio quanto ao papel dos intelectuais no processo de transformação de nosso país.

A principal crítica atribuída por Holanda aos intelectuais brasileiros das décadas de 1920 e 1930 era o fato de trabalharem descolados da realidade, alheios a ela; ou então sob a pretensão de alterá-la, sem antes de mais conhecê-la. A tal percepção, ele associava a ideia de que muito do que nossos pensadores escreveram e desejaram correspondia à importação, e portanto atrofiado senso crítico.

Para Freyre, as importações não apenas de produtos e técnicas como de ideias, no Brasil, teriam começaram a ocorrer de forma mais intensa no século XIX. Antes disso - quer dizer, no período colonial e sob controle português -, o Brasil era mais autêntico, porque 
nessa terra se misturavam elementos americanos, europeus e orientais. Depois, os referenciais ocidentais se sobrepuseram a todos, e fomos perdendo o tom de autenticidade.

Como exemplo que supostamente comprova tal tese, Freyre usava dados variados sobre os modos de ser do brasileiro oitocentista, dos mais fúteis aos mais cruéis. Em Sobrados\& mucambos, Freyre escreveu:

dizem que D. João VI quando chegou à Bahia em 1808 foi logo mandando iluminar a cidade: era 'para o inglês ver'. Outros dizem que a frase célebre data dos dias de proibição do tráfico de escravos, quando no Brasil se votavam leis menos para serem cumpridas do que para satisfazerem exigências britânicas (FREYRE, 2004, p. 429).

No Post-scriptum a seu ensaio, Paulo Prado falava também em "vício da imitação":

Tudo é imitação, desde a estrutura política em que procuramos encerrar e comprimir as mais profundas tendências da nossa natureza social, até o falseamento das manifestações espontâneas do nosso gênio criador. (...) Nessa terra, em que quase tudo dá, importamos tudo: das modas de Paris ideias e vestidos ao cabo de vassoura e o palito. (...) Passa pelas nossas alfândegas tudo que possui as bênçãos da civilização: saúde, bem-estar material, conhecimentos, prazeres, admirações, senso estético (PRADO, 2001, p. 204).

Além disso, tal ensaísta considerou como decorrente da reprodução de fórmulas, e do desinteresse por pensar alternativas próprias de bem viver, o atraso intelectual. Como lembra Leite, ele abordou, em Retrato do Brasil, o fato de que o Romantismo, expressivo na Europa entre os anos 1830 e 1850, perdurou como mais importante referencial teórico político e literário até fins do século XIX, no Brasil. Assim, em nosso país teria resultado centra tensão entre "o lirismo romântico" da "positividade da vida moderna e das forças vivas e inteligentes que constituem a realidade social" (PRADO, p. 181).

Bomfim também abordou a tendência de sempre contarmos com referenciais estrangeiros, como problemática. E, se Freyre operou sua análise de tal aspecto para criticar o liberalismo brasileiro, e Prado para criticar o romantismo e sua tristeza alienada, Bomfim o fez sob a pretensão de confrontar seus principais inimigos intelectuais - os teóricos raciais, os teóricos do branqueamento. Escreveu, em América Latina: males de origem:

Temos de convir que é absurdo, reconhecendo que o estado político e econômico do país não é bom, pretender e esperar que os estrangeiros o venham reformar e organizar, educar e aperfeiçoar. Quem emigra, emigra para melhorar de sorte, e não para organizar nações e fazer pátrias; e, quando o faça, há de fazê-lo para si, e não para quem se confessa por si mesmo incompetente (BOMFIM, p. 197).

Caso também havia considerado, em texto de 1923, uma "importación extralogica" a opção dos mexicanos pelo republicanismo federalista. Lá escrevera: "Los hombres todos, 
mexicanos o no, buscamos siempre lo que creamos mejor (...); pero las condiciones de México hicieron que, como no se había resuelto aún el problema de la conquista (la unificación de la raza, la homogeneidad de la cultura), el esfuerzo democrático resultara fallido" (CASO, p. 70).

Em novo artigo, de 1924, intitulado Las fuerzas sociales de México y la Constitución, ele insistia, uma vez mais, que o fato de os mexicanos serem utópicos os levava a promulgar leis desconectadas de sua realidade (leis "inasequibles", "sin sentido"), e leis que seguiam sendo sistematicamente desrespeitadas (Idem, p. 162). A seu ver, seguir copiando modelos estrangeiros, contudo, não representava apenas um erro, uma estupidez; era a base sobre a qual descansavam muitos dos problemas fundamentais da sociedade mexicana. A seu ver, no México moderno, "la imitación ridícula se convierte en crimen social” (Idem, p. 86).

Segundo Abelardo Villegas, todavia, é Vasconcelos quem, dentre os ateneístas, começou a sistematizar a crítica ao absoluto das noções de superioridade ou inferioridade; é ele quem começa a sistematizar que a avaliação do desenvolvimento social de um ou outro povo correspondente a distintas dadas "escalas de valores", "escalas axiológicas", e não a um parâmetro suficientemente claro, e supostamente atemporal e universalmente válido (VILLEGAS, p. 121).

Em La raza cósmica Vasconcelos se dedicou a criticar ideias correntes acerca da biologia das raças, que as rotulavam e limitavam: criticou "la irredención del indio, la condenación del negro, la decadencia irreparable del oriental" (VASCONCELOS, 1948, p. 35). Apresentou, ademais, uma descrição das cinco raças humanas - o americano, o africano, o asiático, o ariano e o latino - na qual se que atribuía, a cada uma, vícios e defeitos, qualidades e bons hábitos. Ele compreendia que algumas delas cumpriam um ordenamento social mais ou menos interessante; mas, a seu ver, todas elas tinham características fundamentais, a serem incorporadas pela raça mestiça, essa sim superior - a "raça cósmica".

Para tanto, era preciso que cada um desses grupos raciais buscasse se conhecer. Aos brancos, sobretudo arianos, Vasconcelos sugeriu que, para "elevar-se" uma raça precisava não apenas desenvolver-se materialmente, mas espiritualmente. Aos latino-americanos, disse ser necessário "constituir su propia filosofía, el deus ex machina de su éxito"; "comencemos entonces haciendo vida propia y ciencia propia." (Idem, p. 204).

Em outro dos livros de Vasconcelos, Indología (1926), tal perspectiva - o foco no próprio e a crítica às importações - se repetiu: “que sacudamos buena parte de esa ideologia de descastados que hace un siglo padecemos. Filosofía de símios atentos al gesto, 
preocupados de la moda y del estilo, pero incapaces de advertir el sentido profundo del momento que atravesamos" (VASCONCELOS, s/d: 76).

Porém, Vasconcelos não deixou de compreender a cultura mexicana como herdeira da cultura europeia. Isso fica claro em La raza cósmia, no qual apresentou o cidadão mexicano como uma mescla ente índio e latino; e como latina a estrutura civilizacional basilar mexicana. Ali destinos de hispanosamericanos e espanhóis são, enfim, cruzados, na seguinte passagem: "Nosotros no seremos grandes mientras el español de la América no se sienta tan español como los hijos de España. Lo cual no impide que seamos distintos cada vez que sea necesario, pero sin apartarnos de la más alta misión común” (VASCONCELOS, 1948: 205).

Caso apresentou, por aqueles anos, uma percepção parecida com o autor de La raza cósmica, quanto à "originalidade" do pensamento em México e em qualquer outro país da América Latina, América, Europa, mundo. Em resenha ao livro Indología (1926), de Vasconcelos, perguntou: Afinal,

¿quién es original en filosofía, sino los vedas en la Índia y los antisocráticos em Grécia?... Platón resulta inconcebible sin Pitágoras; Aristóteles sin Platón; Plotino sin Platón y Aristóteles; los padres de la Iglesia sin Plotino; Santo Tomás sin la Patrística y Descartes sin San Agustín y San Anselmo, como Leibnitz y Spinoza sin Descartes. Dejemos a los analfabetos del pensamiento su candorosa e infantil locura de la 'idea original', y apoyemos nuestra mente libre y respetuosa en la falange inspirada de los siglos (CASO, p. 42).

Para Caso, os mexicanos deveriam partir do diálogo com outras culturas, e inovar. Disse:

Nuestras formas sociales y políticas proceden de Europa y los Estados
Unidos de América. (...) Pero urge ya, por la felicidad de nuestro pueblo,
que cesemos de imitar los regímenes político-sociales de Europa, y nos
apliquemos a desentrañar de las condiciones geográficas, políticas, artísticas,
etcétera, de nuestra nación, (...) el ideal de nuestra actividad" (CASO: 86).

Bom, podemos dizer que, como aluno não apenas de Vasconcelos, mas também de Caso, Ramos veio a bem definir os conceitos de "transplantação", "imitação" e "assimilação".

Quanto a Ramos, entregou esses termos da seguinte maneira: afirmou que, enquanto os espanhóis se dedicaram a trazer à América seus padrões civilizacionais (a "transplantá-lo"), os americanos se dedicaram a tentar copiá-los, como se não fossem capazes de criar referenciais próprios (a "imitar”). Ao que tudo indica, ao ver de Ramos os indígenas de fato não disporiam de uma base suficientemente sólida para fazê-lo, mas, com o tempo, o homem americano começou a estruturá-la. E seria hora de investir nessa base (RAMOS, p. 98 e 102). 
Ao conceito de "imitação", Ramos contrastou, logo, o conceito de "assimilação". Defendeu, pois, lembrando muito os argumentos de Caso, que não seria em si problemático uma cultura se constituir por meio de assimilação cultural, quer dizer, ser uma "cultura derivada".

Segundo Hernández Luna, Ramos teria aprendido, portanto, com Caso que "Para ser original no es necesario pensar lo que nadie piensa. Basta con que comprendamos e incorporemos tan intimamente el pensamiento ajeno que al pensarlo lo creemos de nuevo y lo hagamos nuestro" (HERNÁNDEZ LUNA, 1956, p. 41).

Desde que houvesse um esforço e disposição para encarar e proceder adaptações, seria, conforme esse autor, saudável aprender e tomar referenciais outros. Daí, apresentar uma interessante metáfora, que nos remete ao texto de Holanda:

Algunas [culturas], las más antiguas, han germinado y crecido en el mismo
suelo que sustenta sus raíces. Otras, las más modernas, se han constituido
con el injerto de materiales extraños que provienen de una cultura pretérita,
la cual, rejuvenecida por la nueva savia, se convierte en otra forma viviente
del espíritu humano (RAMOS, p. 103).

Ora, tanto a aludida metáfora de Vasconcelos, sobre uma "Filosofia de símios", mímica do estrangeiro, como tal metáfora de Ramos, sobre as "raízes" europeias da cultura mexicana nos remetem a metáforas trabalhadas por intelectuais brasileiros das mesmas décadas de 1930. Em Libertinagem, Manuel Bandeira apresentou os célebres versos, em que fazia uma ode ao modo de falar do brasileiro, e criticava as formas eruditas de se compor poemas; dizia ele, que no Recife de sua infância "a vida não (...) chegava pelos jornais nem pelos livros/ vinha da boca do povo na língua errada do povo/ língua certa do povo/ porque ele é que fala gostoso o português do Brasil/ ao passo que nós/ o que fazermos/ é macaquear/ a sintaxe lusíada” (BANDEIRA, 1980, p. 341).

Quanto à metáfora das "raízes" é tão simplesmente a metáfora que justifica o mergulho de Holanda, o crítico literário em crise, o jornalista viajado, a pensar sobre o brasileiro moderno, através de um salto em direção ao passado; e com destaque para as conexões culturais e fundacionais entre Brasil e Europa.

Devemos lembrar, porém, que a Holanda, em seus primeiros artigos, publicados na década de 1920, demonstrara preocupação com a estruturação de um modo literário brasileiro, autêntico; e pouco mais (HOLANDA, 1996, p. 35-41). Conforme Arnoni Prado, teria sido, então, justamente pelo contato com os modernistas que ele "passou a relativizar o conceito de autonomia” (PRADO, p. 309), e a se abrir, pouco a pouco, a maiores concessões ao diálogo com produtos culturais vindos de fora do país. 
Em O futurismo paulista, de 1922, então, ele se utilizou da expressão "pontos de contato" com as vanguardas europeias, exata expressão empregada por Mario para abordar a mesma questão no Prefácio interessantíssimo, que abria o livro de poemas Paulicéia desvairada, de 1921/1922 (Idem, p. 132). E em Os novos de São Paulo, de 1922, seguiu trabalhando a mesma lógica: "em lugar de tomarem por mestres [aos artistas estrangeiros], [os militantes modernistas] desenvolveram na medida do possível a própria personalidade, tomando-os apenas por modelos de rebeldia literária" (Idem, p. 148).

Às vésperas do retorno ao Brasil, afinal, Holanda sentenciava, a respeito da Alemanha, onde vivia como correspondente de $O$ jornal:

nenhum outro país se mostra hoje tão hospitaleiro a produções culturais de seus vizinhos. Suas fronteiras estão livremente abertas às influências espirituais mais diversas e mais longínquas. Uma cultura sem fronteiras... Eis aí a grave censura que tem recaído constantemente sobre o pensamento alemão. Um latino, habituado às construções rígidas e irredutíveis que the legaram os séculos, dificilmente pode compreender essa tendência para exceder sempre os limites propostos ou convencionados, essa resistência a qualquer definição. (...) $\mathrm{Na}$ verdade o pensamento alemão é tão pouco sistemático que os sistemas aparecem nele como construções forjadas e impostas. Um esforço malsucedido para opor diques à sua irresistível fluidez (Idem, p. 280).

Bom lembrar, ainda, que os dois manifestos lançados por Oswald, nos revelam um movimento interessante, nas reflexões desse literato; um movimento semelhante ao desenvolvido por Holanda, entre os anos 1920 e 1936: no primeiro desses textos o Pau-brasil, de 1924, ele defendia a necessidade de se trabalhar em uma poesia de exportação; no segundo, o Antropófago, de 1928, se apoderar de concepções estrangeiras, para criar o novo, o nosso, o bom e belo em filosofia e arte (ANDRADE, 2009, p. 455).

Outro ponto importante: Ramos, como aluno de Vasconcelos, destacou que o cardápio de modelos de pensamento e ordenamento, acessado pelos mexicanos, não incluía apenas itens europeus. Vasconcelos, de sua parte, naquelas primeiras décadas do século XX, já parecia considerar os norte-americanos como um perigo maior, em se tratando de influência cultural, sobre a Ibero-América (VILLEGAS, 1960, p. 66). E Ramos, mesmo que denominasse o primeiro capítulo de El perfil "La imitación de Europa en el siglo XIX", a bem da verdade - como vimos - começa criticando que os mexicanos de meados dos oitocentos tenham tomado emprestado dos Estados Unidos a matriz do texto constitucional (RAMOS, p. 98-99).

Lembremos, pois, que conforme Britton, o subsecretario mexicano de Instrucción Pública, Moises Sáenz, assumindo o posto logo após Vasconcelos abandonar o cargo, teria 
sofreu forte oposição. Como vimos no segundo Capítulo, Vasconcelos e seus partidários, dentre os quais talvez Ramos, o chamavam "pocho" - designação pejorativa para o mexicano que cede aos interesses imperialistas dos Estados Unidos (BRITTON: 78). Mizzi nos informa, então, que tais detratores se voltavam sobretudo contra a opção de Sáenz por dialogar com as propostas educativas de John Dewey, de quem Sáenz foi aluno na Columbia University. Criticavam o princípio deweyano do "learning by doing", e a proposta de uma "escuela de la acción” para o México (MIZZI, p. 6); tendências que supostamente colidiam com a noção vasconcelista de educação humanista voltada ao espiritual, ético e poético.

Nesse sentido, o hiperión Abelardo Villegas defendeu que "el comunismo en México [e eu acrescentaria: também a referencia de Sáenz a Dewey] significaba[n], con el mero hecho de existir, que los ideales propios de la Revolución no eran efectivos, no eran buenos para conducir la marcha del país" (VILLEGAS, p. 109).

Também Holanda, desde seus primeiros escritos, demonstrou importar-se com a cultura yanquee, e, em grande parte das vezes, de forma a temê-la e rejeitá-la. Em 1920 publicou o artigo A quimera do monroísmo, no qual sugeriu que os interesses dos Estados Unidos, embutidos na Doutrina Monroe, largamente difundida no Brasil, não seriam mais temerários do que os interesses europeus, no que tange nossas riquezas naturais e humanas (HOLANDA, 2011, p. 8).

Em outro artigo do mesmo ano apontou características positivas do modo de vida dos estadunidenses, como "a disposição a certos trabalhos", "o poder de iniciativa, a considerável atividade física e a incomparável força de organização" (HOLANDA, 1996, p. 44); mas, considerando a civilização brasileira e a civilização norte-americana "civilizações opostas", rejeitou que pudéssemos aprender algo com eles.

E como os literatos mexicanos se posicionaram, nesses debates?

Conforme Carlos Monsiváis, pode ser difícil e vão buscar definir o "grupo sin grupo" dos contemporáneos. Como vimos capítulos anteriores desta Tese, eles não apresentaram programa ou manifesto. Todavia, se isso se pretende, um bom ponto de partida é considerar suas "predileciones estéticas, lecturas esenciales, (...) admiraciones" (MONSIVÁIS, 2002, p. 60). Porque, para Monsiváis, haveria, sim, um quadro comum de interesses estéticos, compartilhado pelos amigos editores dessa revista. Diferentemente dos estridentistas, por exemplo, muitos deles se interessaram pela produção francesa, da qual pinçaram inspiração sobretudo dos surrealistas, de Andre Gide, de Jean Cocteau, e, ainda, do simbolismo oitocentista, com destaque para os versos de Paul Valery (Idem, p. 66-68). 
Da antologia de Contemporáneos publicada por Manuel Durán, podemos destacar o hábito de publicarem não apenas críticas e composições literárias próprias, mas também versos de autores estrangeiros; pistas sobre seus gostos e diálogos com a Literatura dita “internacional”. Estão entre os autores selecionados ali: o argentino J. L. Borges, o chileno Pablo Neruda, o inglês T. S. Eliot (DURÁN, 1973).

A propósito, Monsiváis põe, realmente, destaque no gosto dos contemporâneos pela vanguarda em espanhol (Juan Ramón Jiménez, Luis Cernuda, Garcia Lorca - espanhóis, José Lezama Lima - cubano), e inglesa (com foco em Wystan Hugh Auden) (MONSIVÁIS, p. 78).

O diálogo de Ramos com Ortega y Gasset, que não remete nem a Vasconcelos nem a Caso, talvez tenha se devido, então, em grande parte, à convivência com os comtemporáneos, que foram profundos admiradores do novo pensamento espanhol, e também foram leitores da Revista de Occicente, editada por Ortega.

Em face de tal quadro - ambíguo e tensionado - Paz, em El laberinto de la soledad defenderá, afinal, a tese de que os ateneístas seriam "os precursores intelectuais da Revolução”. A seu ver, sim, teriam sido Vasconcelos e Caso, que, de forma mais clara e sistemática, começaram a pensar que o México precisava, para bem entender-se, de filosofias e metodologias de reflexão próprias, em diálogo com o estrangeiro; e nisso teriam influenciado não apenas a geração de 1930, mas também a de 1940-150, de Paz (PAZ, p. 15).

Ora, de fato os ateneístas defenderam a importância de se pensar com originalidade; entretanto, como viemos apontando, a abordagem que realizaram acerca de temas modernos, políticos, materiais, sociais, nacionais, foi difusa. Seus textos e conferências abordavam, sobretudo, o âmbito da cultura, da academia, da intelectualidade, da filosofia.

Ao ver de Abelardo Villegas, afinal, é por isso que os integrantes do Ateneo devem ser considerados "filósofos de revolución" (mais do que "filósofos revolucionários"): "se encuentran en el momento de haber negado el pasado, de haver liquidado sus cuentas com él y de no haber construído todavía un futuro (VILLEGAS, 1960, p. 98).

Conforme apontei anteriormente, contudo, ao ver de Ramos, Vasconcelos corresponde a uma quase-inflexão. Em El perfil Ramos afirma que, se não chegou a realizar muito, o professor teria pretendido era promover justiça social, "revolución en la enseñanza" e também “por la enseñanza” (RAMOS, p. 138).

O programa de Vasconcelos para a educação tem sido vastamente estudado: tinha como objetivo principal reduzir os índices de analfabetismo; e pretendia que a alfabetização se desse conforme as necessidades nacionais. Por isso, Vasconcelos planejou investir na 
criação de escolas pelos mais diversos rincões do país; e também em "maestros misioneros" (IDEM: 152) que iriam ao meio rural avaliar as condições de trabalho, e formar professores gabaritados. Fundaria, diz Javier Ocampo Lopes, "escuelas normales rurales", “escuelas normales ambulantes", fomentaria a atividade editorial, construiria bibliotecas. A educação urbana ficaria a cargo de estados e municípios; já que, para ele, os grandes problemas sobretudo o problema da dispersão, dos localismos, do atraso - estariam no campo (OCAMPO LOPES, p. 151-154).

Deve-se ter em mente, aqui, que todas essas práticas foram estabelecidas sobre o seguinte terreno filosófico: em La raza cósmica Vasconcelos havia definido três estágios ou de desenvolvimento para a humanidade; os quais iam do predomínio da força física, passando pelo predomínio da razão, até chegar à mais completa liberdade, na qual reinaria a fantasia, o gozo estético (PÉREZ, p. 329-330). Para Vasconcelos, então, era preciso alfabetizar e ensinar os mexicanos do campo a serem mais produtivos, mas era preciso ter sempre em mente que o ideal a ser alcançado, que a composição da "raça cósmica", só seria logrado por seres humanos espiritualizados, cultos, poéticos.

Em artigo do final dos anos 1910, Caso defenderia a necessidade de transformações, no âmbito da educação nacional, que lembram, bastante o que Vasconcelos proporia, mais tarde. Diria, por exemplo, sobre a tradição intelectual positivista: "el defecto fundamental de la educación puramente científica, desde el punto de vista moral, es que implica una práctica asiduamente egoísta e utilitaria" (CASO, p. 51).

Vale agora dizer também que, em sua já citada obra La existéncia como economia, como desinterés y como caridad (1916), esse autor apresentara possíveis modos de ser e viver, na modernidade, que lembram alguns dos estágios de desenvolvimento que seriam descritos por Vasconcelos, em La raza cósmica (1925). Se Vasconcelos falaria em estágios material, racional e estético, Caso falara numa lógica de vida pautada no interesse econômico; outra alheia à matéria, egoísta mas divina, guiada pela intuição artística; e uma terceira, interessada no mundo, generosamente, e cujo primado seria fazer o bem (VILLEGAS, p. 61).

Anos mais tarde, contudo, Caso questionaria o foco que as políticas educacionais, desde Vasconcelos, concediam à alfabetização das massas, em suposto prejuízo do investimento nas universidades. Diria, para nosso inevitável assombro:

Creemos que la educación de las masas y la campaña por el alfabeto lo harán todo. ¡Imposible! La humanidad constituye una gran pirámide. No nos pongamos en adoración ante vanos ídolos de la falsa igualdad (...); ni [practiquemos] el culto trivial a la universalidad de la ignorancia (CASO, p. 122). 
É, nesse sentido, famosa a crítica que Holanda redigiria anos depois, em Raízes, a respeito dos clichês educativos em voga em todo o mundo.

Conforme Simon Schwartzman, "quando Capanema assume o Ministério da Educação em 1934, o Brasil continuava um país de analfabetos, e o tema da educação pública preocupava" (SCHWARTZMAN, p. 265).

A preocupação, porém, não era nova. Um dos ensaístas brasileiros considerado nos Capítulos anteriores desta Tese, e que, como temos visto, em diversos sentidos apresentou argumentos semelhantes aos de Ramos, a respeito do México, defendeu, desde seu primeiro livro, datado de 1905, a importância da reflexão sobre o ensino, no Brasil - refiro-me a Manoel Bomfim.

Segundo Rebeca Gontijo, “entre 1898 e 1902, Bomfim atuou no magistério ensinando Moral e Cívica na Escola Normal, onde também foi professor de Pedagogia e Português. Nesta mesma escola, dirigiu o Pedagogium, instituição destinada à pesquisa educacional. Também foi membro do Conselho Superior de Instrução Pública do Distrito Federal, sendo que, em 1899, assumiu a Diretoria da Instrução Pública, cargo que deixou em 1907. Neste mesmo ano, atuou como deputado federal, particularmente interessado em questões relativas ao ensino público" (GONTIJO, p. 135).

Se nos voltarmos para o texto de América Latina, encontramos a seguinte exaltada afirmação de Bomfim:

É a IGNORÂNCIA, é a falta de preparo e de educação para o progresso - eis a inferioridade efetiva; mas ela é curável, facilmente curável. O remédio está indicado. Eis a conclusão última desta longa demonstração: a necessidade imprescritível de atender-se à instrução popular, se a América Latina quer se salvar (BOMFIM, p. 360).

Como nos conta Schwartzman,

o Ministério da Educação foi criado em 1931, e em março de 1932 foi divulgado o Manifesto dos Pioneiros da Escola Nova, [que,] redigido por Fernando Azevedo (...), argumentava que o Brasil estava avançando economicamente, mas que a educação estava ficando para trás (SCHWARTZMAN, p. 266).

Por isso, como sugere Silviano Santiago, "não é difícil argumentar que a discussão de Holanda sobre a educação tenha como pano de fundo - e objeto de crítica velada" tais tendências (SANTIAGO, p. 231).

Não que Holanda considerasse desprezível o projeto de erradicação do analfabetismo, no Brasil, e a universalização do acesso à educação formal, pública. O que Holanda discute em Raízes são os postulados do Manifesto, que Capanema endossava: a ideia de que a escola 
era a principal ferramenta de transformação dos indivíduos, e, portanto, da sociedade brasileira; e a ideia de que a educação, no Brasil, se deveria fincar sobre as bases do afeto.

A condenação a essas duas concepções, por Holanda, não se dá de forma explícita em Raízes; porém, facilmente podemos inferi-la, a partir da leitura de duas significativas passagens. Em uma delas, talvez mais famosa, quase no final do livro, Holanda afirma que "a simples alfabetização em massa não constitui talvez um benefício sem-par. Desacompanhada de outros elementos fundamentais da educação, que a completem, é comparável, em certos casos, a uma arma de fogo posta nas mãos de um cego" (HOLANDA, 1999, p. 166).

Em uma passagem anterior, do capítulo O homem cordial, apresentara como efetivamente "nova", moderna, a educação que focasse o desenvolvimento de individualidades; que rompesse com "a velha ordem familiar", a "comunidade doméstica". A seu ver, os "filhos aterrados" seriam adultos de personalidades mais adaptáveis e transformadoras, além de responsáveis (Idem, p. 143-144).

No livro publicado por Freyre no mesmo ano que Raízes, há uma ideia semelhante. O ensaísta pernambucano sugere que os colégios internos representariam ao meninos das classes privilegiadas uma maior liberdade de pensamento, por ampliar parâmetros de reflexão; "esses alunos de colégios de padres [teriam sido], uma vez formados, elementos de urbanização e universalização" (FREYRE, 2004, p. 187). Quando os jovens que seguiam para estudar no estrangeiro, e retornavam bacharéis, Freyre acrescentou: seriam "rapazes tão sem medo, tão sem respeito pelos mais velhos e até pelos santos, pelo próprio Santíssimo Sacramento" (Idem, p. 2004: 199).

Contudo, para o autor de Sobrados \& mucambos, esses filhos da elite, letrados, eruditos, assim se educariam tendo como parâmetro modos de viver e pensar completamente alheios ao país natal, ao qual retornariam, e que desejaram transformar; parâmetros pouco úteis, como vestimentas pouco adaptadas ao nosso clima, e um "liberalismo falso" (Idem, p. 437).

Argumento que, afinal, lembra bastante a crítica modernista de Holanda, à importação de teorias, de sistemas de ideias descolados de nossa realidade, de nossos interesses.

Em El perfil, Ramos não chegou a lamentar a alfabetização como um projeto vulgar (tal como Caso, sobre o México) ou limitado (tal como Holanda, sobre o Brasil). Mas apresentou sua crítica sobre as ideias educacionais mexicanas: lamentou que a busca por um olhar mexicano sobre o México estivesse sendo perdida, no decorrer daqueles anos, devido ao esvaziamento do trabalho intelectual, universitário. Para ele, como os ateneístas não foram precisos em suas versões sobre o mexicano e seus procederes tenderam a ser idealizados, 
utópicos, passaram a enfrentar o desprestígio, a favor de princípios filosóficos que inspiraram maior respeitabilidade e segurança.

Como já foi tido nessa Tese, Ramos não citou nomes, mas, com base nos marcos temporais que apresentou, podemos considerar que desferia sua crítica ao governo de Calles e ao Maximato. Esse foi um momento em que os ideais revolucionários passaram a ser abordados, nos discursos, sob uma perspectiva mais pragmática; e em que o staff governamental voltou a recorrer à clara importação de teorias. Consideremos, assim, alguns dos projetos educativos apresentados, desde que Vasconcelos abandonou a secretaria.

Como pontuei em capítulos anteriores, o Maximato flertou com o marxismo, muito mais como rótulo, do que como teoria a ser posta em prática. Dos intelectuais que então ganharam destaque, devemos citar, mais uma vez: Lombardo Toledano e Bassóls.

Voltando-se contra ele Ramos sugeriria, em El perfil, que, tal como a democracia liberal havia sido um equívoco, no México, porque incompatível com a realidade local, e seus dilemas raciais, seria um equívoco importar o socialismo marxista (CASO, p. 71).

Nos anos 1930, em debate com Lombardo, a crítica ao marxismo se intensificara também em Caso. Então, ele escreveria: “¿Aboliremos em la Facultad de Filosofía y Letras la libertad de pensamiento?" E se refere a marcos da História da Filosofia, como Platão, Descartes, Pascal, Hegel, antes de prosseguir questionando:

“¿Será todo esto ideologia burguesa y maldita? (...) Yo reniego de esa proterva Universidad enemiga de la cultura humana (...); porque lo único que distingue al hombre del rebaño, es el mundo de los valores, reflejado en la luz de su inteligencia, la pureza de su conciencia y la energía de su voluntad, que sirven de vehículo al bien (Idem, p. 109).

Vimos que, tendo retornado da expedição pela Europa com grande prestígio, em 1932, Ramos fora designado Oficial Mayor da secretaria, por Bassols, que recém havia assumido o cargo. E que, de acordo com Hernández Luna, à época, Ramos considerou positiva a possibilidade de trabalhar junto a Bassols, porque o considerava um administrador capaz de lidar com problemas estruturais da educação mexicana; e porque, então, ambos compartilhavam a ideia de que era necessário suprimir o laicismo do ensino, no México, conforme postulado pela Constituição de 1917 (HERNÁNDEZ LUNA, p. 205).

Acontece que, com o tempo, as intenções de Bassols foram sofrendo alterações. Se contou com Calles para alterar o artigo $3^{\circ}$ da Constituição revolucionária e oficializar o que chamou "educação socialista"; passou a apoiar a concepção anti-religiosa do Jefe Máximo, e abandonar a preocupação com o espitirual, o ético, o poético no ensino (Idem, p. 206). Daí a 
notável desilusão de Ramos com os destinos do ensino público mexicano, constante nas linhas de El perfil.

Interessante é que os colegas de Ramos, editores e colaboradores da revista Contemporáneos, também tenham se interessado pela crítica projeto de "educação socialista", tanto quanto Ramos. Ao ver de Jorge Cuesta, por exemplo, o socialismo, aplicado à educação, por um Estado capitalista, não passava de uma "falacia" (CUESTA, 2004, p. 66).

Já a perspectiva de Villaurrutia aparece não em um ensaio ou estudo crítico, mas em seus Poemas proletários, em meio aos quais se destacam versos irônicos, através dos quais o eu-lírico comenta o fato de as rádios divulgarem informações oficiais, sobre as alterações constitucionais, nos seguintes termos: "El comunismo es una doctrina extraña en nuestro médio,/ (...) pero la Educación Socialista/ preparará a tus hijos a vivir el momento histórico/ y la realidad mexicana dentro de los postulados/ del Instituto Político de la Revolución Mexicana" (NOVO, p. 112). Ora, daí podemos concluir que, na visão de Novo, o projeto do ministro do Maximato era absurdo, paradoxal: pregava uma doutrina educativa que se sabia descolada da realidade mexicana, ou mesmo dos projetos oficiais, para o México; e por fazêlo sob o argumento de que era estritamente necessário.

No Brasil, como o socialismo foi uma doutrina considerada oficialmente como inimiga do Estado revolucionário, a designação de "socialista" tendeu a ser vista como uma opção crítica, não-conformista.

Filiaram-se ao Partido Comunista muitos de nossos mais expressivos intelectuais; e com isso sofreram represália do governo Vargas; são bons exemplos, Graciliano Ramos e Caio Prado Junior. Mas também houve aqueles que, como funcionários de Vargas e Capanema, ainda assim flertaram com o socialismo, como Carlos Drummond de Andrade, sobretudo em seu Sentimento do mundo (1940).

Dos vanguardistas modernistas mais representativos, lembremos que Oswald também conviveu com sindicalistas, operários, foi integrante do PC e editou periódicos socialistas, como O homem do povo, com sua esposa Patrícia Galvão, a Pagu. Devido ao convívio com a teoria marxista e com comunistas brasileiros, passou, inclusive, a dedicar-se cada vez com maior interessa ao estudo da História e da Filosofia.

Na introdução-testemunho de Tentativas de mitologia, de 1979, Holanda afirmaria que desde muito jovem se havia desinteressado do marxismo, por considerá-lo dogmático. Não haveria de ser essa uma característica inaceitável para um pensador que tanto desprezou antecipações, prejuízos, idealizações comprometidas politicamente, e arrogância intelectual? 
Em sua última entrevista, datada de 1981, contou que: "tinha uma inclinação para esquerda", e embora "ainda não conhecesse Marx", procurou Octavio Brandão "para entrar no Partido Comunista". Teria sido uma experiência desanimadora: Brandão "vivia citando números, como se todo o mundo tivesse condição de ficar o tempo inteiro checando a veracidade do que dizia. (...) Então começou a dar irritação conversar com ele" (Apud. MARTINS, 2009, p. 188).

Porém, muitos são os registros nos quais se sugere que Holanda foi à Europa com o propósito primeiro de, por fim, conhecer a Rússia comunista; e que só permaneceu entre a Alemanha e a Polônia, ao longo de sua estadia de mais de um ano, por impossibilidades burocráticas, e, depois, por medo do inverno moscovita.

Seus artigos redigidos do território alemão e polonês, para a imprensa brasileira, é verdade, indicam efetivamente seu largo interesse pelo marxismo/comunismo. Nos informam, por exemplo, seu projeto de entrevistar uma série de grandes intelectuais marxistas, como o francês Henri Guilbeaux (Apud. BARBOSA, 1988, p. 148).

Porém, chegando ao Brasil, em diálogo com Manuel Bandeira, teria se apresentado como cada vez mais desinteressado com o projeto de comunista: "Quando saí daqui [do Brasil] eu tinha uma tendência para o comunismo. Hoje estou achando nele o mesmo excesso racionalista do catolicismo. Comunismo e catolicismo são soluções extremamente racionalistas" (Idem, p. 293).

Numa mesma linha, em Corpo e alma do Brasil, artigo sobre os modos de ser do brasileiro moderno, que antecedeu a publicação de Raízes, apresentava um ponto de vista semelhante ao de Ramos, dos contemporáneos; ao propor o comunismo como um projeto desinteressante, para o Brasil e para a América Latina, simplesmente por ser um projeto formulado no estrangeiro, e não necessariamente condizente com as possibilidades e interesses nacionais. Escreveu: “As revoluções que desligaram [as nações ibero-americanas] das metrópoles adotaram como base das suas cartas políticas os princípios da Revolução Francesa, então na ordem do dia, pelos mesmos motivos que ainda hoje levam os povos coloniais a contemplar com unção os ideais apregoados pela Terceira Internacional” (HOLANDA, 2008, p. 591).

Conforme Antonio Candido, afinal, Holanda foi crítico do marxismo como teoria de interpretação porque "eram uma repetição mecânica e ritualizada do marxismo oficial" (CANDIDO, 1982, p. 8).

Temos, assim, que tanto no caso do Brasil como do México em que viviam, respectivamente, Holanda e Ramos, as grandes transformações percebidas por tais autores 
vinham sendo pensadas no decorrer da prática da transformação. Daí a tensão, em um como em outro desses ensaístas, entre o que julgavam ser novidade, e o que julgavam ser continuidade; entre o que consideravam ser importante manter, e o que consideravam permanência a ser superada.

Nesse sentido, ambos valorizaram a ação como fator essencial da tarefa de se pensar o homem e a cultura em seus países, na modernidade. Holanda, falando de e focando uma certa "espontaneidade" brasileira, e Ramos defendendo a formação de um intelectual que fosse ao mesmo tempo erudito e conhecedor das especificidades, do dia-a-dia, do homem comum mexicano.

Ambos, portanto, foram críticos da importação de sistemas de ideias estrangeiros, assim como de sistemas concebidos em "torres de marfim" (o Romantismo idealizador, e a detração indiscriminada, cientificista). E desejaram que se conformasse, entre nós, modos de entender-nos autênticos, diversos, e mais próximos do "real" local.

Assim, foi para ambos fundamental pensar sobre as políticas educativas; ainda que em vieses distintos. Holanda, pois, criticou a ideia de que escolas, pura e simplesmente, pudessem transformar os rumos do pensar, e da nação brasileira; enquanto Ramos criticou escolas de formação estritamente técnica, que não levassem em conta os fluxos e ritmos próprios de seu país, e um modo de pensar mais poético, estético, humano.

Julgaram fundamental pensar, ainda, sobre como as ideias trabalhadas por intelectuais e políticos se converteram em leis, e em que medida tais leis, assim que institucionalizadas, foram se convertendo em costumes generalizados. Eis, aqui, especificamente, o tema da próxima seção. 


\subsection{Alterações legais e obstáculos procedimentais}

Na presente seção abordarei como a tradição de pensar a Revolução de 1930 e a Revolução Mexicana considerou os costumes de brasileiros e mexicanos no que diz respeito às leis. Apresentarei, então, as percepções que Holanda e Ramos tinham acerca dessa questão, cruzadas às percepções de outros intelectuais mexicanos e brasileiros, que também estavam escrevendo e publicando sobre o assunto.

Das ponderações de Holanda, vale sublinhar: em Corpo e alma do Brasil, artigo que antecedeu a publicação de Raízes, e no qual refletia sobre os modos de viver e se relacionar do brasileiro contemporâneo, repetiu em diversas passagens a expressão "espírito legístico": era a maneira de se referir a nosso então corrente costume de pensar e trabalhar pela oficialização de dadas leis (Cf. HOLANDA, 2008: 590).

A respeito, em Raízes, Holanda afirmaria ser um hábito corrente, no Brasil,

pretender-se compassar os acontecimentos segundo sistemas, leus oi regulamentos de virtude provada, em acreditar que a letra morta pode influir por si só e de modo enérgico sobre o destino de um povo. A rigidez, a impermeabilidade, a perfeita homogeneidade da legislação parecem-nos constituir o único requisito obrigatório da boa ordem social (HOLANDA, 1999, p. 178).

Nesse ensaio, voltando-se para o passado colonial, Holanda definiu - vimos no capítulo anterior - um quadro um tanto distinto: pontuou como característica da ação da metrópole lusa o desleixo; em suas palavras, “a dominação portuguesa (...) renunciou [no território que hoje corresponde ao Brasil] a trazer normas imperativas e absolutas" (HOLANDA, 1999, p. 95).

O desinteresse pelos padrões oficiais, imparciais, de bem viver, nessas terras tropicais, seria peculiar não apenas na unidade administradora, como dos habitantes, em geral. Daí que os poderes locais se fizessem determinantes; mesmo no que diz respeito à Igreja, que de Roma logrou impor pouco aos padres "negligentes", "gananciosos", "dissolutos" (HOLANDA, 1999, p. 119).

Conforme Caio Prado, em Evolução política do Brasil, na Colônia, "toda população (...) vivia (...) na mais completa dependência dos senhores rurais" (PRADO, p. 29); "o estado colonial" foi, assim, "instrumento de classe desses proprietários", e em muitas ocasiões “contrariava as próprias leis da metrópole” (Idem, p. 32).

Freyre também: sublinha "a administração da justiça pelo patriarca sobre a família" (FREYRE, 2004, p. 180). 
Mas em Sobrados \& mucambos notava que tais noções estariam se dispersando, desde o final do século XIX, no Brasil. "Posturas municipais começaram a defender a rua, dos abusos da casa-grande"; a "limitar os abusos do particular e da casa e fixar a importância, a dignidade, os direitos da rua" (FREYRE, 2004, p. 33).

O movimento que levou à Revolução de 1930 foi, pois, em parte, resultante do anseio generalizado, no Brasil, por novos parâmetros legais; que atendessem, por exemplo, questões eleitorais. Desde a Proclamação da República, a promulgação da primeira constituição republicana, em 1891, os presidentes brasileiros eram definidos pela larga prática de compra de votos, manipulação, "votos de cabresto", entre outras fraudes. Daí, a predominância política das oligarquias de São Paulo e Minas Gerais, configurando a chamava "República do Café com Leite". A chegada de Vargas ao poder, sustentado por políticos e militares da capital, do Rio Grande do Sul, da Paraíba, era, pois, uma reação à manutenção do sistema, que se considerava à mercê de determinados interesses localistas, e não gerais; do sistema que se considerava baseado na ilegalidade e na imoralidade.

Vargas chegou ao poder por uma via não-legal, é verdade. Mas logo tratos de regularizar a situação. Em 1932 foi publicado o novo Código Eleitoral brasileiro, que instituía o voto secreto, o voto feminino, e que todo o processo eleitoral deveria ser arbitrado por tribunais especiais e imparciais - era criada a Justiça Eleitoral (NICOLAU, 2002).

O novo Código também considerava a problemática dos poderes locais, prevendo, para logo, eleições indiretas que permitissem a regularização das alterações institucionais se dessem de maneira tranquila; o que de fato ocorreu em 1934, por ocasião da Constituinte, com a vitória de Vargas (NICOLAU, 2002: 102).

Também conforme Vasconcelos, em ensaio sobre o México, a relação ambígua dos mexicanos em relação às leis remeteria a períodos remotos da história nacional, e mesmo a antes disso, ao período colonial; deveriam, então, ser encarados não como naturais dos cidadãos de seu país, e sim como resultante de várias condicionantes, experimentadas ao longo de séculos. Para ele, em La raza cósmica, "la civilización no se improvisa ni se trunca, ni puede hacerse partir del papel de una constitución política; se deriva siempre de una larga, de una secular preparación y depuración de elementos que se transmiten y se combinan desde los comienzos de la Historia" (VASCONCELOS, 1948, p. 19).

O passado precisava, ser, pois, ao ver de Vasconcelos, reconsiderado, analisado, se se pretendia a estruturação de um efetivo estado de direito, no país. Se mais forte do que as leis eram as práticas; era preciso refletir sobre a prática de elaboração de leis e de descumprimento de leis, antes de formulá-las e oficializá-las. 
Ramos também entendeu tanto o fetiche do mexicano pela formulação de normas, quanto a prática de não respeitá-las como hábitos repetidos, retomados, instituídos, no território que hoje corresponde ao México, desde o período da colonização espanhola.

Para Ramos, desde o período da colonização espanhola, os homens e mulheres do território que hoje corresponde ao México viveriam sob uma autoridade superior, estranha e estrangeira. Tardou que, ali mesmo, se conformasse um grupo ao qual se atribuísse considerável poder de decisão; e, quando isso ocorreu, quer dizer, com a Independência, mesmo esse grupo acabou por estabelecer relações de respeito a autoridades outras - como a Áustria, a França, os Estados Unidos. Disso decorreu, afinal, a sedimentação, no caráter do mexicano, da percepção de dados padrões de ordenamento social como solenes, inquestionáveis.

Em El perfil Ramos apresenta o mexicano como povo formal, que gosta de defender ideais e de falar bonito; e o mesmo seria válido no que diz respeito às leis: haveria uma relação "fetichista" do mexicano, em relação às leis, que o levaria a sempre pontuar que eram importantes, mas quase nunca cumpri-las (RAMOS, p. 113).

É de se lamentar, pois, que tenha faltado ao autor de El perfil trabalhar com mais exemplos de experiências práticas, reais, relativas aos anos mais recentes da história do México. A respeito do tema da lei, ele abordou sobretudo o período da Independência e da Reforma, quando fato é que a análise da Revolução seria um prato cheio para a crítica que propôs.

Toda a história da Revolução Mexicana pode ser encarada como um claro exemplo de como a formulação de leis correspondia a um fetiche para os mexicanos. Dos anos de 1910 a 1920 há, naquele país, a proposição sucessiva de inúmeros planos-manifestos-padrões-deconduta, pelos mais diversos líderes: Madero escreveu o "Plan de San Luis", em 1910; Zapata, o "Plan de Ayala", em 1911; Pascoal Orozco, o "Plan de la Empatadora", em 1912; Carranza, o "Plan de Guadalupe", em 1913; Calles, o "Plan de Agua Prieta”, em 1920.

No que diz respeito a princípios políticos e eleitorais, no "Plan de San Luís" Madero defendeu dois principais pontos. Primeiro, registrou e assegurou que "una de las primeras medidas del gobierno provisional [sería] poner en libertad a los presos políticos" (Apud. GARCÍADIEGO DANTAN, 2005, p. 67); depois, declarou oficialmente que "los princípios de sufrágio efectivo y no reelección, como únicos capaces de salvar a la República del inminente peligro con que la amenaza la prolongación de una dictadura cada día más onerosa, más déspota y más inmoral” (Idem, p. 70). 
Em 1913, Carranza proferiu um célebre discurso, que o consolidou como principal força política de oposição ao contra-revolucionário Victoriano Huerta; nele, falava sobre a importância de se "cambiar la legislación", "implantando normas com uma estrutura moderna" (Idem, p. 105). Quando presidente do México, logrou organizar uma assembleia constituinte, passando a ser considerado baluarte de uma perspectiva revolucionária mais legalista, e homenageado num seguinte corrido que os mexicanos cantavam assim: "Por la muerte de Madero/ siguió la Revolución; no aceptamos los valientes/ eso de la Usurpación. En la plaza de Saltillo/ brilló el sol de la esperanza,/ al levantar la bandera/ don Venustiano Carranza" (Idem, p. 104).

A Constituição de 1917 formalizou, afinal, que, no México, "ninguna persona podría hacerse justicia por sí misma, ni ejercer violencia para reclamar su derecho”. Formalizou também as duas notas do "Plan de San Luis" que destaquei acima. Primeiro, a liberdade de organização política, e expressão de ideias: "Ninguna ley ni autoridad puede establecer la previa censura, (...) ni coatar la libertad de imprenta” (Idem, p. 87). Depois, garantiu a eleição do presidente por voto direto, e a não-reeleição, nos seguintes termos: "El ciudadano que haya desempeñado el cargo de Presidente de la República, electo popularmente, o asuma provisionalmente la titularidad del Ejecutivo Federal, en ningún caso y por ningún motivo podrá volver a desempeñar ese puesto" (Idem, p. 88).

Mas, conforme o entendimento de Ramos, ocorreu que, longe de Castela, não havia sido difícil, aos colonos, escapar ao controle metropolitano, ao controle do rei, ao controle do papa. Destarte, pouco a pouco, mais e mais, desenvolveram uma moral, uma tradição, uma ética consideravelmente fluida, observável do mexicano do século XX.

John Reed, em México insurgente, defendeu uma tese semelhante: a seu ver os mexicanos apenas não respeitavam leis por falta de um efetivo referencial de autoridade justa. Ele afirmou em seu relato que as tropas revolucionárias cumpriam sim regras básicas de convivência; defendeu que, durante grande parte de sua estadia entre aqueles rudes e miseráveis homens, embora levasse consigo algum dinheiro guardado e um relógio, não temeu ser roubado, pois o clima de convivência era de respeito e segurança.

Em determinado momento, efetivamente, furtos teriam começado a ocorrer, praticados pelos integrantes dos bandos, entre si, e o autor admitiu que, em meio às intensas dificuldades por eles vivenciadas, acabou, ele próprio, por se apossar de bens de outros, também. Fundamental fazer notar, entretanto, que, conforme Reed, o clima de tranquilidade voltou prontamente ao normal com a chegada de Villa - referencial de justiça, autoridade (REED, p. 278-279). 
Já Azuela, em Los de abajo, não apresentou uma visão tão positiva do mexicano. O roubo aparece nesse romance como prática comum, por parte dos integrantes dos bandos combatentes, revolucionários; e mesmo como algo que eles percebiam como positivo, como índice de masculinidade (AZUELA, 2000).

Após a elaboração da Constituição de 1917, a percepção das leis como solenes instituições pareceu ter ganhado novas dimensões, nos discursos dos chefes e na Literatura mexicana. Daí em diante, políticos passaram a justificar mais e mais suas ações não apenas definindo-as como relevantes socialmente; mas declarando que estariam a proceder conforme norma acordada. Entretanto, ainda assim isso não implicou em devido cumprimento da norma.

Bom lembrar, então, que embora Vargas tenha se esforçado por garantir a seu governo não apenas uma aura de novo, como de legítimo; e embora seja conhecido como um dos grandes responsáveis pela formulação de todo o aparado institucional moderno, brasileiro; também tem sido lembrado pelo descaso em relação às leis.

Há uma frase que se atribui a ele, não se sabe ao certo a circunstância, mas a qual se associa um tom de deboche: "A lei, ora, a lei”. Uma das versões da história dessa expressão foi apresentada por Domingos Franciulli Neto: Vargas, que regularizou as primeiras leis que garantiam direitos aos trabalhadores brasileiros, teria pronunciado tal frase, anos mais tarde, em um comício, ironizando a preocupação de empresários paulistas com gastos e complicações decorrentes do cumprimento da legislação trabalhista (NETTO, 2003).

Em conferência de 1967, Holanda apresentaria algumas reflexões sobre a época em que escrevera Raízes; e lembraria que as leis propostas por Vargas "ao início de sua administração revolucionária" foram tidas como "das mais avançadas para o tempo"; porém, em muito sentidos, permaneceram no âmbito "simbólico" (HOLANDA, 2008, p. 632).

Em La sombra del caudillo, Guzmán retomou, no contexto da cidade e do poder institucionalizado, o total descaso na prática dos ditos "revolucionários", no que diz respeito ao cumprimento das leis; e a associação entre as ideias de desonestidade e virilidade. Como disse o narrador desse livro, os líderes revolucionários se caracterizavam por algo como um “placer de lo inmundo" (REED, p. 40),

Há nessa obra diversos exemplos disso, de forma que ao leitor fica claro que, na visão de seu autor, não correspondia a um desvio de comportamento, e sim ao comportamento padrão. Cito, a princípio, a seguinte passagem: Ignácio Aguirre, ministro da guerra e suposto candidato à presidência do México, protagonista da obra, aceita receber propina para liberar a uma empresa estrangeira um terreno que havia sido expropriado pelo Exército. Nesse 
momento, então, um dos personagens declara, como forma de justificar a ação: "México disfruta por ahora de uma ética distinta de las que rigen en otras latitudes" (Idem, p. 124).

Em La sombra del caudillo temos outro bom exemplo de como os discursos e práticas andavam desencontrados: a atuação do Caudillo, cujo nome não se revela, mas que é, afinal, no livro, a figura politicamente mais relevante do México. O Caudillo de Guzmán controla as informações divulgadas nos jornais, e faz com que a imprensa apresente fatos distorcidos, a favor de seu grupo. Além disso, é ele quem decide qual será o candidato oficial à presidência, e não o voto dos populares integrantes do Partido; ele garante, ademais, base de apoio entregando a seus aliados grandes propriedades de terra que deveriam ser repartidas entre camponeses, conforme a lei da reforma agrária. Por fim, prende generais opositores, dentre os quais Aguirre, sem que eles nada efetivamente houvessem feito de ilegal; e esses generais são executados. O Caudillo, note bem, descumpre claramente os dois princípios do "Plan de San Luís" que destaquei acima: ignora o direito à livre expressão de ideias; e não permite que se faça valer o sufrágio universal.

Ironicamente, o personagem, ainda assim, ao final da obra, faz questão de declarar-se em prol do rigoroso cumprimento da legislação eleitoral; e declara que a nação estaria já “ansiosa de que sus gobernantes lleguen al Poder por virtud de las leyes" (GUZMÁN, p. 213).

Aqui cabe apontar que de fato o Caudillo de Guzmán se parece bastante com Obregón e Calles. Calles, por exemplo, ante ao assassinato de Obregón declarou que seria imprescindível passar à "condição histórica de "país de (...) instituições e leis"” (Apud CARMÍN; MEYER, p. 125). Entretanto, ao longo dos mandatos de ambos não houve paz ou voz para a sua oposição, e, ademais, ambos não chegaram a demonstrar considerável respeitou aos princípios de "sufrágio efectivo" e de "no reelección”.

Tzvi Medín insiste na ideia de que, embora as leis formalizadas viessem de alguma maneira cercear as ações individualistas, passionais, egoístas, violentas, o cumprimento delas não se podia tornar, do dia para a noite, uma prática, no México. Focando as normas eleitorais contidas na Constituição, esse autor afirma que constavam como garantia à coletividade, e obstáculo aos interesses individualistas de chefes como Obregón e Calles, mas esses chefes possuíam uma base de apoio tão forte, que as manipulavam, interpretavam, desdobravam, e em alguns casos chegavam mesmo a esvaziá-las de sentido (MEDIN, p. 16).

Por exemplo: quando se ia encerrar o mandato de Calles, Obregón dedicou-se a negociar a viabilização de sua segunda candidatura. A princípio propôs uma interpretação completamente duvidosa do texto da norma, segundo a qual poderia ele legalmente propor nova candidatura. Ora, como nos sugere Medín, se lemos mais uma vez o trecho da 
Constituição a respeito do tema, que transcrevi parágrafos acima, não podemos, porém, de forma alguma concordar que ela abre qualquer margem para mal entendidos; tampouco a malícia de Obregón, no período, teve eco. Mas ele acabou por convencer os legisladores a alterar o texto da Lei, sob o argumento de que sua força era ainda necessária para vencer a dispersão das consciências (MEDIN, p. 22-23).

No mais, podemos dizer que, tendo sido Obregón assassinado logo após eleito, Calles, o presidente em exercício, não se sentiu à vontade para se propor a continuar governando. Surgiu, pois, o projeto do Partido Nacional Revolucionário, que seria chefiado por ele próprio, e cuidaria de indicar sucessores, como de regular a ação dos próximos eleitos.

Assim, de acordo com Camín e Meyer, logo na primeira eleição presidencial que seguiu a morte de Obregón, um agente do serviço secreto norte-americano teria declarado: “É provável que Vasconcelos [da oposição] tenha o maior número de partidários, mas parece evidente que será eliminado. Tem contra si a máquina do governo" (Apud. CAMÍN; MEYER, p. 208). ${ }^{14}$

Quer dizer que, nas primeiras décadas do século XX, entres os intelectuais do México, circulava a ideia de que o descumprimento das normas coletivas era expressivo em todos os estratos sociais: quanto aos homens mais simples, como aos chefes de Estado, havia a impressão de que seriam escassas as referências de bom proceder. Tal como entre os brasileiros, sobre o Brasil, havia a impressão de que mesmo quando havia uma autoridade referencial, ou mesmo por essa autoridade referencial, as leis não tendiam a ser obedecidas.

Nossos pensadores e escritores seguiram, pois, buscando outras possíveis explicações para o descaso dos mexicanos no que tange ao cumprimento das leis.

14 Javier Garciadiego, no Brasil conhecido por seu trabalho com a divulgação de documentos históricos do período e para estudo da Revolução Mexicana, defende a tese de que a campanha entre Vasconcelos e Ortiz Rubio teria sido suja (envolvendo violência e compra de votos); porém que, efetivamente, Vasconcelos não teria contado mais votos que o candidato callista. Antes de mais, o professor mexicano considera que a certeza quanto à fraude contra Vasconcelos foi construída por seus companheiros, intelectuais, que carregaram a imprensa e editoras com suas versões tendenciosas, mas encantadoras, que conteriam uma suposta "verdade" acerca daquelas eleições, e que como "verdade" foram sendo lidas pelos intelectuais/críticos da Revolução, em gerações posteriores. Depois, afirma que Vasconcelos era um jovem pensador, e sua força política não podia efetivamente competir com o poder e o carisma do PNR, Calles e seu escolhido, o michoacano Pascual Ortiz Rubio. Em terceiro lugar, Garciladiego se refere à crise econômica internacional, de 1929, e sugere que haveria, como decorrência dela, expectativas, por parte dos mexicanos, de um presidente que transparecesse experiência e segurança, e não enfrentamento, desafio, como Vasconcelos. Em quarto lugar, o pesquisador menciona a autonomização da Universidade Nacional, efetivada por Portes Gil, presidente provisório em exercício, aliado de Calles; a qual esvaziou um tanto o programa de Vasconcelos. Em quinto lugar, Garciladiego sublinha o fato de Vasconcelos se dirigir à classe média (que era numericamente restrita) e jovens estudantes (que não votavam), enquanto o candidato de Calles, Ortiz Rubio, falava a todas as classes, todas as raças, toda a gente de México (GACIADIEGO DANTAN, 2009). 
Em Corpo e alma do Brasil, Holanda apresentava Alberto Torres como outro autor que, bons anos antes, já se havia referido a uma clara diferenciação, no Brasil, entre nação e Estado, entre vida social e política, entre práticas e leis (HOLANDA, 2008, p. 593).

Da mesma geração que Torres, Bomfim, saltando para o passado colonial, escreveu, em América Latina: males de origem: "o governo da Coroa deixava ao colono toda a plenitude de ação para o mal” (BOMFIM, p. 159); "a legislação [assim] nada podia fazer contra a tendência dos costumes" (Idem, p.120).

Em Retrato do Brasil, Paulo Prado também apresentara os portugueses que vieram à América como semelhantes aos brasileiros moderno no seguinte ponto: em ambos os casos, seriam criadores e descumpridores compulsivos de normas - "Leis, leis, leis. Só faltou aquela (...) que mandaria pôr em execução todas as outras" (PRADO, 2001, p. 207).

Freyre igualmente se referia a leis formuladas por um Estado que parecia completamente desinteressado no que diz respeito à gente que governa: em Sobrados \& mисатbos, mencionou normas formuladas já para o Brasil independente, que definiam os "estilos de trajo", "consagrando o repúdio aos modos de trajar mais ostensivamente rurais ou rústicos", e repercutindo mais em caos do que em ordenamento, quer dizer, em inúmeras revoltas como a dos cabanos, balaios, farroupilhas (FREYRE, 2004, p. 508).

Conforme Ramos, em El perfil, em meados do século XVI, além de distante, a autoridade espanhola dedicou-se a compor normas que estavam de acordo com seus próprios interesses, alheios, e não conformes às necessidades dos habitantes da colônia. Os colonos não podiam, assim, percebê-las como legítimas, daí ignorá-las.

Depois, quando o México passou a ser controlado por outras potências e cumprir novos regimes de dominação, tais práticas se mantiveram correntes. Até que se cristalizasse o hábito de os próprios mexicanos escolherem para si, de sua própria vontade, modelos de legislação absolutamente inadequados, inúteis, impróprios à sua realidade (RAMOS, p. 9798).

Para Ramos, urgia elaborar leis mais condizentes com a realidade; no que ele fazia lembrar Caso, que defendera, anos antes, que inspirados em suas próprias condições geográficas, históricas e intelectuais, os mexicanos elaborassem "los moldes mismos de [sus] leyes; las formas se [su] convivéncia” (CASO, p. 86).

Registre-se que Madero denunciava, em seu "Plan de San Luís", a mesma noção, proposta pelo autor de El perfil, e seu professor Caso, a respeito das leis vigentes no regime porfirista: elas haveriam, mas não eram cumpridas porque não encontravam eco nos corações e mentes mexicanos. Nesse documento, pode-se ler: "los derechos del ciudadano solo existen 
escritos en nuestra Carta Magna; pero de hecho en México casi puede decirse que reina constantemente la Ley Marcial” (GARCILADIEGO DANTAN, p. 87).

Declarando-se maderista, Vasconcelos, em Ulises criollo, assim descreveu a corrupção do sistema judicial porfirista:

Cuidaba siempre Don Porfírio de mezclar, a los ochos jueces de la capital, a los viente Magistrados de la Suprema Corte, dos o tres reconocidos bribones de que se valía para forzar sentencias en los casos que le convinieren (...). De los concusionarios y serviles decía [el] en su léxico de estadista romo y vulgar, que eran el 'retrete' necesario en toda casa (VASCONCELOS: 259).

Vasconcelos chamou, por fim, a Porfírio Díaz de "el burlador de la Constitución que cada seis años juraba cumplir" (VASCONCELOS, p. 23).

Ora, se uma das razões que explicavam o não cumprimento das leis era serem elas desinteressantes e deslocadas da realidade local, e se se considerava, cada vez mais, no Brasil e no México, a necessidade de buscar leis que condissessem com a realidade nacional, o que explicaria que elas seguirem sendo desrespeitadas?

Muitos dos pensadores brasileiros e mexicanos, então, outra razão para tanto: o personalismo, tema do próximo capítulo. 


\subsection{O papel dos grandes chefes e dos afetos}

A passionalidade, apontada por Holanda e Ramos como característica do brasileiro e do mexicano, envolveria, conforme suas análises, tanto um tratamento bruto quanto uma proximidade afetiva; aparece, pois, em seus célebres ensaios, como fundamentos de alguns dos mais sérios problemas, no Brasil e no México contemporâneos. A tal passionalidade, mais do que um agir irracional, impensado, envolve, tanto em Raízes como em El perfil o culto a personalidades, a valorização dos laços familiares, de compadrio e de amizade, e dificuldade e/ou desinteresse por ser impessoal.

Consideremos, que, se o afilhado espera do padrinho determinados favores, é de se supor que o padrinho se sinta à vontade não apenas por decidir quais favores seriam esses, para ser controlador e por vezes violento, e também para acessar maiores privilégios, para si. Assim como no direito de puni-lo caso seja contrariado. A garantia de segurança apenas poderia ser comprada com a moeda da docilidade, da subserviência.

Note-se que o familismo implicou, constantemente, pois, tensões e rivalidades; desentendimentos que eram passados de geração para geração, rancores jamais solucionados, ódios estancados apenas pelo assassinato ou o exílio forçado. Por cordial/passional, teve como característica não apenas o afagar e proteger, mas o vingarse.

Leitora dos ensaístas brasileiros da década de 1930, Schwarz afirma que "a iniciativa de colonização teria sido sempre entregue a particulares, residiria aí a singularidade da colonização ibérica, marcada pelos fortes vínculos pessoais, que tornam fluidas as delimitações entre as esferas públicas e privadas de atuação" (SCHWARCZ, 2008, p. 87).

Em Casa-grande \& senzala, abordando o período colonial brasileiro, Freyre falava sobre a importância do chefe carismático e temido: "no íntimo, o que o gosto do que se pode chamar 'povo brasileiro' ainda goza é a pressão sobre ele de um governo másculo e corajosamente autocrático" (FREYRE, 2001, p. 123).

Isso contrasta um tanto com descrição feita por Holanda, em Raízes, de nossas preferências e tendências, mas confirma a importância respeito, admiração, pelos líderes. No modo de ver de Holanda, na política brasileira, seria 
indispensável que as peças de seu mecanismo funcionem com certa harmonia e garbo. O Império brasileiro realizou isso em grande parte. A auréola que ainda hoje cinge, apesar de tudo, para os nossos contemporâneos, resulta quase exclusivamente do fato de ter encarnado um pouco esse ideal (HOLANDA, 1999, p. 177).

No prefácio à segunda edição de Paulística, de 1934, Paulo Prado descreveu o clima político que envolveu a Revolução de 1930 como "uma atmosfera carregadíssima de retórica"; e denunciou que os líderes políticos de então teriam abafado os anseios por reforma com intensa campanha de valorização afetiva dos atributos pessoais do líder força e garantia de benefícios materiais, o gaucho Getúlio Vargas (Apud. CALIL, p. 18).

Quanto a Vargas, ao mesmo tempo em que se envolveu na elaboração de leis que ordenavam o sistema eleitoral, e também garantiam os direitos políticos e benefícios sociais a setores marginalizados até então; ao longo dos tantos anos em que se manteve no poder empreendeu uma série de ações restritivas, punitivas, censura e controle de sindicatos e da oposição.

Ao ver de José Murilo de Carvalho, "o setor militar da burocracia estatal" conquistou importante papel no governo Vargas (CARVALHO, 1983, p. 109), trabalhando por "um projeto hegemônico (...), que iria aos poucos eliminando propostas alternativas, até consolidar-se com o golpe de 1937” (IDEM, p. 111).

Nesse sentido, foi importante também a atuação da polícia, na figura do chefe de política Filinto Müler. Ligado a Vargas desde 1930, foi um dos líderes da operação que sufocou a Revolução Constitucionalista, em 1932; e tornou-se Chefe de Polícia do Distrito Federal desde 1933; a partir de 1935, esteve à frente da ação propagandista anticomunista e ficou conhecido como perseguidor de Julio Prestes e Olga Benário (BELOCH \& ABREU, 2001).

A historiadora Janete Leiko Tanno afirma, em interessante estudo, que

Legitimadas por códigos, normas, leis e discursos, as práticas repressivas atacaram diretamente os comunistas, os 'subversivos e extremistas', por meio de prisões e torturas. Porém, o restante da sociedade não ficou ileso a outras práticas de controle, como a vigilância e a delação, por exemplo. Todos os dispositivos repressivos, dos mais sutis aos mais explícitos, tinham por objetivo maior interiorizar normas, valores e condutas que fizessem de cada indivíduo um defensor e propagador da 'nova ordem'.

De 1930 até a decretação da Lei de Segurança Nacional, em 4 de abril de 1935, a repressão incidiu principalmente no movimento operário, prendendo comunistas, anarquistas, trotskistas, integralistas, opositores políticos (como os revoltosos paulistas de 32) e obedeceu aos reclamos da política de controle do social, como em outros países 
liberais e democráticos. Arbitrariedades e abusos do poder da polícia eram comuns, mas a sociedade ainda estava amparada por uma Constituição liberal (após junho de 1934) e um Código Penal, e não havia sido legalmente acionado nenhum dispositivo cerceador das liberdades (TANNO, p. 55).

Vargas foi, assim, chamado "pai dos pobres", tanto pelas oportunidades que parecia abrir, com sua política nacionalista e desenvolvimentista, quanto pela força de sua autoridade - mantendo, assim, o pêndulo entre a análise de Freyre e a de Holanda, sobre a preferência dos brasileiros por um governo que se diria bondoso ou forte; Vargas parecia concentrar em si ambos os atributos.

Contudo, antes de pensar Vargas tão somente como um homem dotado de enorme talento para agregar aliados, e mobilizar e conter as massas, devemos entendê-lo como alguém que desde muito jovem aprendeu a lidar com a dinâmica familista. Seu pai foi coronel de grande importância, no sul do país, ligado a um importante político, conservador, dos primeiros anos da República brasileira: Borges de Medeiros.

Conforme a análise de Gunter Axt, Getulio Vargas: a gênese de um mito, passando por um período de dificuldades políticas e econômicas, os Vargas teriam contado com a ajuda de Borges de Madeiros: "na política coronelista do Rio Grande do Sul, em que o estado podia controlar meios importantes, tais como a distribuição de cargos públicos, e a liberação de créditos, ou o resultado dos processos judiciais, o custo de ser oposição poderia ser muito elevado" (AXT, p. 5).

Segundo o mencionado historiador, o futuro ditador usufruiu dos contatos de Medeiros, e assim foi de deputado a governador do estado do Rio Grande do Sul. Para não contrariar o "padrinho", teria cogitado negar inclusive o convite do presidente paulista Washington Luís, para assumir o Ministério da Fazenda; mas, por fim, com o consentimento de Medeiros, acabou aceitando. Era seu acesso à política federal; e a possibilidade de se projetar, politicamente, em nível nacional (Idem, p. 19). ${ }^{14}$

Ramos buscou no passado colonial explicações para o comportamento do mexicano moderno, em relação aos chefes. Nos fez recordar, pois, que desde o século XVI as classes mais altas mantinham seus luxos não por força do trabalho, e sim a partir da concessão de privilégios pela Coroa espanhola. Da ausência de uma autoridade considerada amplamente como justa, decorreria que prevaleceria, no caráter de todos os

\footnotetext{
${ }^{14}$ Após a chegada de Vargas ao poder, através do golpe de 1930, Borges Medeiros se tornou opositor, tendo lutado na Revolução Constitucionalista, e se apresentado como candidato de oposição, nas eleições indiretas, para presidente, de 1934. Foi sobretudo crítico ao direcionamento centralizador da política de Vargas.
} 
mexicanos, mesmo na modernidade, "la volundad de poderio"; o desejo de se sobressair sobre os demais (RAMOS, p. 168).

Em Forjando pátria, Gamio também concedera destaque a tal costume mexicano: "la 'política mexicana', impropiamente llamada así, fué un conjunto heterogéneo difícil de identificar: personalismo, lucro de determinados individuos y castas, adulación, temor, ambiciones" (GAMIO, p. 137-138).

Em seu Laberinto de la soledad, Paz estabeleceu, quanto ao personalismo, um raciocínio semelhante ao de Ramos: associou o personalismo ao contexto injustiça e insegurança; e abordou a caótica dinâmica político-social. Conforme Paz, do fato de "para o mexicano a vida [corresponder a] possibilidade de chingar ou de ser chingado", decorria o servilismo, a dependência a determinados chefes, considerados mais fortes (PAZ, p. 74).

Segundo Lorenzo Meyer, a queda do Porfirismo remete, em parte, ao costume do personalismo. Esse historiador sugere que a coesão do Estado Porfirista tinha como referencial a forte e carismática figura de Díaz; que chegado o século XX Díaz estava ficando velho e sua imagem desgastada; e que tal sistema não podia contar com outra figura política, à altura, como nova referência que seguisse amalgamando a dada pluralidade de interesses (MEYER, 1987, p. 34).

Os líderes revolucionários mexicanos estiveram atentos a isso e costumaram insistir, desde seus primeiros discursos, numa crítica ao personalismo porfirista. Sabemos que Madero defendeu, em seu "Plan de San Luis", a liberdade política, aliada às concepções de sufrágio efetivo e a não-reeleição. E que ele o fez por acreditar que era necessário formalizar leis que permitissem que o México deixasse de ser um país violento e personalista. Cabe agora ressaltar que consta, ainda, no dito documento, a seguinte denúncia: "Todo el engrenaje administrativo, judicial y legislativo, obedece a una sola voluntad, al capricho del General Porfírio Díaz" (GARCILADIEGO DANTAN, p. 86).

Quando se refere a Madero, em Ulises criollo, Vasconcelos afirma que não baseara seu poder em seu carisma: "ninguno de nosostros dejó llevar de la pasión personal; todos o casi todos conveniamos en la lealtad del punto de vista de Madero" (VASCONCELOS, p. 453).

Carranza, considerado referência legalista, declarou, em 1914, em célebre discurso, que pretendia 
demostrar que no le animaban sentimientos bastardos e ambición personal, sino que, en vista de las dificultades existentes, su verdadero anhelo eran (...) los triunfos de la Revolución triunfante"; e que "con el propósito de no entrar en una lucha de carácter personalista (...) [se ponía] de su parte todo cuanto le era posible para una conciliación (Apud. GARCILADIEGO DANTAN, p. 123).

No texto de Reed temos um bom exemplo de como essa situação se deu também, continuadamente, no contexto revolucionário. O jornalista pergunta a um jovem por qual motivo ele havia optado por integrar nas tropas de determinado chefe, e ele responde: "Quem se abriga sob uma boa arvore é protegido por uma boa sombra" (REED, p. 71).

Como já foi dito aqui, nesta Tese, em La hacienda, do estridentista Xavier Icaza, a terra é menos um direito pelo qual lutam os "peones" do que um benefício que o bom terrateniente lhes proporciona.

Do que depreendemos que os líderes revolucionários, em geral, tenderam a seguir percebendo o acesso a dados benefícios não como algo que o Estado mexicano deveria promover, e que era de direito dos cidadãos; e sim como algo que determinados líderes, mais humanos, mais sensíveis ou mais eficientes (quer dizer, dotados de qualidades pessoais) viabilizavam. Nisso lembravam bastante Vargas, que, como vimos há pouco, foi chamado "pai dois pobres".

Friedrich Katz avalia a importância desses laços entre os líderes revolucionários, e aponta que muitos dos chefes políticos que se destacariam ao longo da Revolução, antes do início dela, foram profundamente queridos em seus estados de origem; e reproduziram, quando na chefia de algum posto administrativo, a mesma lógica: valeram-se de seu carisma, e de uma relação afetiva, ao menos no âmbito do discurso, com os cidadãos mexicanos. As famílias Madero e Carranza, por exemplo, eram materialmente remediadas, de maneira que costumavam garantir acesso à educação e saúde para seus empregados, agregados, arrendatários, conquistando, fidelidade, e, depois, apoio decisivo para as disputas contra Díaz e Huerta, respectivamente (KATZ, p. 96).

Contudo, para Holanda e Ramos, a passionalidade, nos hábitos políticos de brasileiros e mexicanos, respectivamente, não foi compreendida apenas no hábito de cultuar chefes carismáticos; estaria presente em todo tipo de relação, incluindo as econômicas e políticas. Schwarcz fala, nesse sentido, em "personificação do espaço público" (SCHWARCZ, 2008, p. 86). 
Para Freyre, "o patriarcalismo, criando economias autônomas, ou quase autônomas, aguçando o individualismo dos proprietários e o privatismo das famílias, enfraqueceu na gente das casas-grandes o desejo de solidariedade - ainda hoje tão fraco no brasileiro de origem rural, quase que sensível apenas ao parentesco próximo e à identidade da religião" (FREYRE, 2004, p. 148).

Freyre, ademais, apontou o "apadrinhamento" como "assunto que está a merecer estudo à parte". E estabeleceu, a respeito, alguns pontos de partida: "foram muito os escravos que, no sistema patriarcal brasileiro, gozaram da situação de afilhados de senhores de casas-grandes e de sobrados e foram, por este status especial, beneficiados em suas pessoas e particularmente protegidos em sua saúde, em seu vestuário, em sua educação" (Idem, p. 407).

A despeito das alterações pelas quais o país vinha passando, haveria, a seu ver, portanto, a continuidade dessa expressão patriarcal: "a transição do patriarcalismo absoluto [tão somente] para o semipatriarcalismo", "do patriarcalismo rural para o que se desenvolveu nas cidades" (Idem, 2004: 238).

Conforme Bomfim, em América Latina: males de origem, no Brasil Colonial "as receitas do tesouro se compunham de privilégios, monopólios. (...) As classes privilegiadas, fruindo todos os rendimentos, distribuíam comedorias à nação sob a forma de empregos e outras” (BOMFIM, 2005, p. 122). Já Paulo Prado, em Retrato do Brasil, falou sobre a "Justiça" injusta de nosso país; a lei, que "dificilmente resiste" "em contato com os interesses da politicagem", com o "arbítrio" e o "abuso do poder" (PRADO, 2001, p. 203).

Em Raízes, Holanda escreveu, a respeito do "homem cordial" brasileiro: "A escolha dos homens que irão exercer funções públicas faz-se de acordo com a confiança pessoal que mereçam os candidatos (...). Falta tudo à ordenação impessoal que caracteriza a vida no Estado burocrático" (HOLANDA, 1999, p. 146).

$\mathrm{Na}$ década de 1970, como observamos em depoimento da época, Holanda mantinha tal ponto de vista, a respeito da política, no Brasil:

O processo caminha como numa briga de família: aparece um primo, um tio ou um amigo (...) com bom relacionamento com ambas as partes capaz de contornar diplomaticamente o confronto direto. E é exatamente no conchavo que pode surgir a figura do homem cordial (Apud. MARTINS, 2009, p. 86).

Na seção anterior, foi abordado o trabalho de institucionalização de algumas leis, por Vargas; hora de pontuar que o ditador foi conhecido pelo hábito de propor normas 
no âmbito do direito de família, modernas e bem vindas, mas inspirado pela necessidade, o interesse dos amigos. É o caso, por exemplo, da "Lei Teresoca", que reconhecia como legítimos os filhos gerados fora do casamento, pensada a partir de um problema vivido pelo amigo Assis Chatobriand, o Xatô - o qual, na década de 1920, foi, como vimos, patrão de Holanda, em $O$ jornal. Xatô havia se separado e passado a viver com outra mulher, com quem não chegou a regularizar a situação conjugal, mas com quem teve uma filha, Maria Teresa. Acontece que conforme a lei em vigor à época, Maria Teresa não poderia ser registrada como herdeira de Xatô, por ter sido concebida fora de um casamento legítimo; e Xatô desejava a guarda dela. A proposta de Vargas veio a beneficiar muitos filhos, chamados "bastardos", e também ao amigo jornalista (MORAIS, p. 435).

Buscando compreender o comportamento político de Obregón e Calles, o historiador sonorense Ignacio Almada Bay cuida de analisar a realidade história do norte do México, em princípios dos novecentos, assim como a infância dos dois generais.

Conforme Ramos, embora o mexicano pudesse ser considerado apaixonado defensor de determinados conjuntos teóricos, e de determinados repertórios de leis, havia uma forte tendência de que tais interesses ficassem restritos ao âmbito do discurso. O mexicano, então, podia pregar ideias e normas não por acreditar efetivamente no que dissesse, e sim como forma de adquirir prestígio e respeitabilidade. Sua fala se dirigiria ao coletivo, mas ele poderia ser e era constantemente em tudo indiferente à coletividade, familista, egoísta, fechado em si (RAMOS: 127).

Segundo Almada, Sonora era, ainda no início do século XX, um estado afastado do controle político federal e também do poder da Igreja, como instituição; disso teria decorrido a expressiva importância, entre seus habitantes, conferida aos laços familiares e de compadrio. Os homens e mulheres da região não tinham uma visão do Estado como instituição objetiva e impessoal, promotora de direitos garantidos por lei. Os casamentos eram negócios, e era dos padrinhos e compadres que se esperava apoio econômico e proteção militar contra os índios, ou contra inimigos políticos.

Num ambiente de dificuldades, as extensões da família nuclear foram muito importantes para Obregón e Calles; o primeiro, por ter perdido o pai ainda muito jovem; o segundo, por ser filho bastardo de um rico proprietário que nunca chegou a assumi-lo formalmente, e por ter ficado órfão de mãe quando criança (ALMADA BAY, 2010, p. 
738). Concentrando sua análise na história de vida do Jefe Máximo, Almada pontua, então:

El primer premio de la lotería de la vida para Plutarco fue haber sido rescatado por una rama de su familia extendida: Josefa Campuzano (hermana de su madre) lo acogió en su casa de Hermosillo, con su esposo Juan Bautista Calles. (...) La adopción del apellido Calles provino [entonces] de la matrícula escolar, ya que así lo registró el [tío], quien tenía por costumbre hacer compadres" (Idem, p. 58-59).

Obregón e Calles chegam, pois, a chefes do governo federal mexicano conhecendo bem tais moedas e negócios. E, já empoçados presidentes, reforçaram tal dinâmica, investem em uma imagem de conciliadores e promotores de benefícios sociais.

Aqui devemos destacar, também, que o personalismo aprendido por Vargas, Obregón e Calles, carregava em seu cerne a lógica da violência.

Por mais institucionalizados que se pretendessem, os presidentes sonorenses são conhecidos por governarem com mãos de ferro, por massacrarem a oposição, por extermínios e prisões arbitrárias - o caso de Francisco Serrano, explorado no texto de La sombra del caudillo, de Guzmán, talvez seja o mais notável.

Tanto Holanda como Ramos, e seus contemporâneos, costumaram destacar que, do inquestionável respeito ao chefe, ou da cordial relação com a política adviria, o hábito de se perceber os negócios e interesses públicos como uma extensão dos interesses pessoais; de mexicano confundir os negócios públicos com os privados.

Holanda não se refere, especificamente, à apropriação, por parte dos burocratas, de dinheiro público. Em Raízes do Brasil, fala-se em benefícios e política de influência. Curioso, então, que ainda hoje reste do antigo ditador a imagem de benfeitor, arbitrário, mas probo.

No México, a questão foi encarada de uma maneira um tanto distinta: em Ulises criollo são várias as denúncias que Vasconcelos fez, nesse sentido. Mesmo que sua narrativa tome como tema o porfirismo, as primeiras movimentações revolucionárias, e a morte de Madero, há várias referências àqueles que seriam os grandes nomes da Revolução institucionalizada - Carranza, Obregón e Calles. Ali o autor os apresentou como desde sempre corruptos; como chefes que, ao chegarem ao poder, pretenderam, sobretudo, obter proveitos para si.

A Carranza Vasconcelos denominou ironicamente "ex-senador porfirista", e afirma que muitos de seus rendimentos advinham de negócios ilegais 
(VASCONCELOS, p. 491). Adiantou, pois, que seu governo seria um marco, no sentido da institucionalização não da lei, mas da "desmoralización total de los servicios públicos" (Idem, p. 297). Para ele, Carranza "convirtió la revolución de ideas, en competencia caníbal de politicastros incondicionales y bandidos analfabetos” (Idem, p. 434).

Camín e Meyer nos lembram que, sofrendo o ataque dos exércitos de Obregón, Carranza teria reunido uma comitiva e sua bagagem em um vagão ferroviário que o levaria para longe da capital; na ocasião, constavam em sua bagagem pessoal o tesouro do governo e alguns documentos dos arquivos públicos federais (CARMÍN \& MEYER: 95).

Vasconcelos tampouco desenhou, em Ulises criollo, uma imagem positiva de Obregón. Ele denunciou o fato de Obregón possuir "haciendas revolucionárias" em Cajeme, e justificou ter apoiado a luta obregonista, quando jovem, por simples falta de opção. Disse haver pensado, em meados de 1914: “Cuando Obregón nos libre de este viejo malvado [Carranza], entonces estaré con él” (VASCONCELOS, 1982: 747).

Vasconcelos afirmou, ainda, que os favorecimentos concedidos aos homens mais próximos dos estadistas marcaram também o mandato de Obregón, como presidente. E, tendo sido ele próprio secretário de Obregón, que sentia a necessidade de desvincular seu nome desse tipo de prática. Contou, assim, que, na ocasião, havia negado a oferta de mudar-se para uma luxuosa residência; já possuía uma casa confortável (Idem, p. 750).

De Calles, Vasconcelos denunciou, por exemplo, mais de uma vez que ele possuiria largas extensões de terra em Mante; as quais deveriam ter sido repartidas aos camponeses (VASCONCELOS, p. 453). Comparou determinado líder revolucionário ao futuro Jefe Máximo da seguinte maneira:

La rudeza mental, la ignoráncia crasa estallaban bajo la capa mundana. Le habían falsificado fama de enérgico, aureola de estadista; y no pasaba de un precursor de Plutarco Elías Calles, sin los antecedentes sanguinarios que hicieron del candidato obregonista un caso más repugnante (Idem, p. 274).

Quanto a Caso, nos faz lembrar as reflexões de Ramos, porque, tal como Ramos, argumentava que em seu país seria mais forte o carisma de determinados chefes, do que o entendimento da importância da impessoalidade das leis. Destacava ainda, nesse sentido, que mais do que repercutir no descaso com o cumprimento de normas, o personalismo fazia com que as próprias normas criadas e estabelecidas não visassem, 
por si, atender interesses comuns, mas beneficiar esses homens mais destacados da política (CASO, p. 162).

Conforme viemos acompanhando, então, o que Holanda chamou "ética de fundo emotivo", e considerou como característica do brasileiro, foi percebido, por Ramos, também no modo de ser e se relacionar dos mexicanos, daqueles princípios do século XX.

Essa ética fundamentada no emocional, passional, impulsivo, e um tanto alheia ou desrespeitosa de toda intenção imparcial, objetiva, institucional impessoal, levava, ao ver desses dois ensaístas, no Brasil e no México modernos, ao culto à personalidade. E se desdobrava tanto no amor ao chefe carismático e temido; como na valorização dos laços familiares e de amizade.

Em Raízes como em El perfil, portanto, sãos relações pautadas nessa "ética de fundo emotivo" que garantiriam, ainda, aos brasileiros e mexicanos, chegados os anos novecentos, passados os eventos menos ou mais caóticos que se denominavam "revolução", que garantiam segurança material e acesso a bens e benefícios materiais.

Do que decorre uma questão: se a palavra "revolução" vem sendo entendida não apenas como processo de mudança, mas de mudança através da qual se constrói uma sociedade caracterizada por maior justiça e prosperidade, como isso se deu no Brasil e no México, dos jovens Holanda e Ramos, ensaístas? Para os autores de Raízes e El perfil era possível que, em sociedades em que os chefes eram cultuados, ou largamente temidos, esses dois fatores - segurança e benefícios - pudessem aparecer juntos, e vigorosos? Havia mudanças notáveis, nesse sentido, no Brasil e no México da época?

Eis as problemáticas a serem exploradas nas próximas seções. 


\subsection{Um grupo no poder, muitos grupos na política?}

Conforme proposto especialmente nas seções deste capítulo, ao ver Holanda, em Raízes, e Ramos, em El perfil, os rumos e continuidades da política, sociedade e cultura brasileiras e mexicanas teriam sido sobretudo de responsabilidade de um determinado grupo.

Vimos também que muitos de seus intérpretes igualam Holanda a Freyre ou aos modernistas como um bloco, assim como Ramos a Gamio, aos ateneístas e a Paz, num mesmo discurso. E que esse discurso é apresentado por tais intérpretes como criticável na medida em que endossaria uma visão positiva e acrítica dos brasileiros e dos mexicanos, conveniente, respectivamente, aos institucionalizadores da Revolução de 1930 e da Revolução Mexicana; e na medida em que desenharia aqueles princípios do século $\mathrm{XX}$ como momento histórico nacional em que as massas populares ganhariam destaque.

Esta seção é, então, dedicada à analise a tradição de crítica da história da Revolução de 1930 e da Revolução Mexicana, que reflete sobre o quão os processos político-sociais brasileiros e mexicanos, naquelas conjunturas, corresponderam mais ou menos a uma dinâmica popular. E como as argumentações contidas em Raízes e em El perfil, aí se localizam; de maneira a endossar ou criticar as interpretações propostas por gerações seguintes àquela na qual se inseriram Holanda e Ramos, quando estavam escrevendo seus ensaios mais célebres.

É larga a tradição de historiadores brasileiros que consideraram a dita Revolução de 1930, como um "rearranjo entre elites", como uma "modernização conservadora", viabilizada por uma Elite, e marcada pelo controle das massas.

Ainda assim, considera-se que o grupo que a promoveram e embasaram foi bastante heterogêneo; e que, portanto, a situação é mais complexa. Conforme Luciano Martins, desde o início dos novecentos alguns setores se teriam destacado na oposição à estrutura administrativa e aos programas políticos em vigor, no Brasil. Seriam eles: frações agrárias excluídas do processo democrático, classes médias urbanas desejosas de maior representatividade, e ainda componentes do Exército (MARTINS, p. 675).

Após Vargas ser empoçado, ficou bem claro que a expectativa de tal grupo era, porém, impedir que mudanças administrativas e na política econômica resultassem em qualquer modificação significativa no status quo; na cidade ou no campo os trabalhadores deveriam ser mantidos sob controle, e as manifestações populares deveriam ser enfrentadas com mais de ferro, pelo Estado. Lembremos, pois, que desde 1922 se havia institucionalizado o Partido Comunista; e que, no mesmo ano, tinha-se contemplado, na capital, o 18 do forte de 
Copacabana, mobilização organizada por tenentistas, que, radicais, em 1925, passaram a compor um movimento rebelde de larga projeção nacional, a Coluna Prestes.

Bom lembrar, nesse ínterim, que, entre nossos pesquisadores mais consagrados, há perspectivas distintas acerca da dimensão da autoridade de Vargas, sobre as massas trabalhadoras: Francisco Weffort e Angela de Castro Gomes, logo, criticam um suposto maniqueísmo das abordagens que sugerem o estabelecimento de um pacto desigual entre um Estado manipulador e uma classe trabalhadora enfraquecida e inerte, domesticada; e falam, respectivamente, em "Estado de compromisso" e "pacto trabalhista" (WEFFORT; GOMES, 1989).

Sonia Regina Mendonça pontua, no mesmo sentido, que de fato o governo Vargas foi bem sucedido na tarefa de desarticulação de interesses tidos como mais radicais, por parte do proletariado; entretanto, que isso não quer dizer que para as massas as leis trabalhistas e outras medidas estatais não possam ter significado qualquer melhoria em suas condições, ou mesmo ter correspondido a expectativas reais (MENDONÇA, p. 35).

A ideia de uma elite que, presa a fúteis padrões de administração, completamente desconectados da realidade brasileira, apareceu também em Evolução política do Brasil, de Caio Prado Junior: para esse ensaísta, D. Pedro II

nunca passou de um bom, e mesmo se quiserem, um ótimo burocrata. (...) [Mas] absorvido por minúcias administrativas e manias literárias que em seu medíocre espírito degeneraram num diletantismo vazio, era ele o instrumento talhado para realizar esta política: apavorava-o tudo quanto significasse marcha para frente (PRADO:103).

Quando abordou o Estado brasileiro, ao longo da história, Bomfim apresentou o seguinte diagnóstico: tanto pela crítica aos poderosos, e por entender que o comportamento desses poderosos ditaria padrões ao comportamento dos mais fracos, como por apresentar um governo completamente desinteressado, no que diz respeito às necessidades materiais do povo.

Escreveu, em América Latina: males de origem:

o Estado [colonial] tem por função, apenas, cobrar, coagir e punir aqueles que se neguem a pagar ao governo centralizador, absolutista, monopolizador. A justiça aparece para condenar os que se rebelam contra o Estado ou contra os parasitas criados e patrocinados por ele. (...) Fora disso, não há mais nada: nem política, nem higiene, nem proteção ao fraco, nem garantias, nem escolas, nem obras de interesse público... nada que represente a ação benéfica e pacífica dos poderes públicos (...) Tal é a tradição; ainda hoje se notam estes sentimentos, porque, ainda hoje, [o Estado] não perdeu seu caráter duplamente maléfico - tirânico e espoliador (BOMFIM, p. 160). 
E, na defesa dos interesses do povo, pontuou: "a marcha das sociedades civilizadas nos aparece como a extinção gradual, contínua, das classes dominantes. (...) É ele - o proletário, o miserável, o inferior, o explorado - que faz prole e garante, pela sua descendência forte, a conservação da nacionalidade" (BOMFIM, p. 72).

Era esse um anseio vislumbrado por Bomfim no início do século XX, mas, em face da não-realização, se reverte, pouco a pouco, em radicalismo; e na defesa, em Brasil nação, de que se processasse uma verdadeira revolução. Nesse outro ensaio, se opôs, pois, indiretamente, à Revolução protagonizada por Vargas; sem mencioná-la, sem citá-lo, criticou os discursos ufanistas, marcados pelo apagamento das diferenças de classe e alienação ante os problemas a serem radicalmente confrontados. Escreveu: "colaboração das classes é, apenas, o engodo com que o trabalhador continua a ser mantido na extrema situação de dependência econômica" (BOMFIM, 1998, p. 697).

Para Gilberto Freyre, entre leis de proteção e restrição, o Estado burocrático supostamente mais impessoal, era tipicamente problemático. Daí que propusesse, em Sobrados \& mucambos, uma reflexão que se estabelecia sobre bases distintas, e alcançava percepções políticas diversas, mas que lembraria o livro de Caio Prado Junior, publicado anos antes: “De D. Pedro II não será talvez exagero dizer-se que sua confiança estava mais nos bacharéis que administrassem juridicamente as províncias e distribuíssem corretamente a justiça do que em socorros de carne e farinha aos povos oprimidos" (FREYRE, 2004, p. 714).

Ao ver de Freyre, o Estado moderno criava maiores dificuldades para as classes que mais precisavam. A "legislação referente a acidentes de trabalho", por exemplo, seria criação da vida nas cidades; mas foi necessário criá-la justamente porque no meio urbano se tornavam mais difusas as proteções dos patrões aos empregados, tão comuns e características da vida no campo (FREYRE, 2004, p. 409). Ademais, vinham acompanhadas de inúmeras outras normas que correspondiam a brutais cerceamentos, aos olhos dos populares; atendendo a interesses de um grupo muito restrito (Idem, p. 513).

Essa era uma ideia que Holanda de certa maneira replicaria, em Raízes:

Foi o moderno sistema industrial que, separando os empregadores e empregados nos processos de manufatura e diferenciando cada vez mais suas funções, suprimiu a atmosfera de intimidade que reinava entre uns e outros. (...) Para o empregador moderno (...) o empregado transforma-se em um simples número: a relação humana desapareceu (HOLANDA, 1999: 142).

Com uma distinção importante: enquanto o ensaísta pernambucano parece saudoso do tempo da escravidão, o ensaísta brasileiro vira o olhar para o futuro.

Nesse sentido, Monteiro pontua, em A queda do aventureiro, que o autor de Raízes parecia defender que se fazia fundamental que os camponeses e operários do Brasil não 
apenas se incluíssem numa dinâmica de mercado outra (se tornassem "trabalhadores"), mas também no "palco da política" moderna. Parecia defender que se fazia fundamental que eles desenvolvessem não apenas num "espírito capitalista" - para usar a expressão de Weber mas também um "espírito de organização e de luta" (MONTEIRO, 1999, p. 288-291).

Conforme Dante Moreira Leite, contudo, em Raízes Holanda concentrava sua interpretação na ação dos grupos favorecidos. Ao ver desse intérprete, "homens cordiais", seriam os brasileiros pertencentes aos extratos sociais mais favorecidos. A dinâmica que envolveria as relações entre patrões e empregados, por outro lado, não seria "cordial", mas “paternalista" (LEITE, 1983, p. 204).

Seguindo a mesma linha interpretativa, para Piva "em Raízes só se viu o passado como construído pelas más elites"; “o lado bom e popular [passa] despercebido" (PIVA, 2000: 24).

Acredito porém, que o que a leitura de Raízes nos sugere é que a cordialidade penetraria, no Brasil, todo tipo de relação. Nas palavras de Holanda, ela poderia ser entendida como "a contribuição brasileira para a civilização"; remetia a algo como "nossa forma ordinária de convívio social”, "um aspecto da vida brasileira (...) característico" (HOLANDA, 1999, p. 146-148).

Entre distintas capas sociais, e sub-hierarquizações, uma dada "ética de fundo emotivo" se estabeleceria sob pretensões e ambições diversas, relativas. Assim, a relação paternalista entre chefes e encarregados, donos e empregados, seria apenas um modo de ser cordial; e não um outro modo de se portal socialmente.

Embora Holanda não se tenha fecha às elites, fato é, porém, que atribuiu, em Raízes, às elites sobretudo, esse comportamento interessado e mesquinho, ademais de "mascarado"; e às classes sociais mais baixas uma cordialidade mais espontânea, e aberta ao novo e ao diálogo (HOLANDA, 1999, p. 184). Conferiu, assim, a essas classes menos favorecidas uma importância histórica a se vislumbrar concretamente, com o desenrolar da "Nossa Revolução".

Conforme apontado em outros capítulos desta Tese, antes de Sobrados \& mucambos, em Casa-grande \& senzala Freyre havia trabalhado a ideia de uma civilização tropical ímpar, autêntica, e bem sucedida, quando da chegada à América e colonização desta porção sul do continente. Tal referência seria tomada pelo ensaísta em diversos outros de seus escritos, de maneira insistente, lamentando o presente moderno tendente à imparcialidade sem-cor, e dourando a pílula do passado. Daí que gerações posteriores de leitores de Freyre o tenham considerado pai da tese da "democracia racial" brasileira. 
Outro intelectual bastante expressivo daquele momento que também foi considerado como importante advogado da ideia de uma "democracia racial" brasileira foi o aqui já citado Cassiano Ricardo. Como vimos no primeiro Capítulo desta tese, Ricardo dialogou com o conceito de "homem cordial", de Holanda, e propôs que os cidadãos do Brasil se caracterizariam por uma bondade, por uma doçura no trato, que deveria ser referencial para todos os povos do mundo. Assim, se diferia tanto das definições propostas por Holanda, como da análise de Freyre, que percebera uma origem afetiva, no brasileiro, pouco a pouco se perdendo.

Vimos no segundo capítulo, ademais, que Ricardo esteve entre os modernistas. Conforme Monica Velloso, ele foi integrante do grupo Bandeira, que embora fosse claramente nacionalista e ufanista, e pregasse como primordial uma ideia de ordem e harmonia social - ideia consubstanciada na flâmula brasileira -, foi crítico ao grupo que em Raízes Holanda denominou "mussolinismo indígena”, ligado a Plínio Salgado, por flertar com doutrinas estrangeiras (VELLOSO, 1983, p. 100).

Como aponta Luiza Franco Moreira, a adesão a Vargas ocorreu apenas após 1937, quer dizer, apenas após a consagração do Estado Novo: ele trabalhou para Vargas, como interventor no estado de São Paulo, e, posteriormente, como editor do jornal oficial, A manhã. Mas mesmo no período que antecede tal virada política no sentido da consolidação do autoritarismo, no governo do Brasil, Ricardo já publicava estudos políticos nos quais ressaltava a importância do sentimento nacionalista, e de um Estado forte, que direcionasse os setores mais pobres, a trabalhar no sentido do desenvolvimento da nação (MOREIRA, 2001, p. 28).

Ora, como também contemporâneo aos fatos, Holanda demonstrou um desconforto considerável, ante a concentração da tomada de decisões nas mais do Estado varguista, com o caráter elitista do "rearranjo", do "compromisso" que representava a Revolução de 1930; um notável desconforto ante a sempre-domesticação dos trabalhadores brasileiros -por meio da violência como do discurso.

Entre o que percebia de bom e de mau na herança das alterações institucionalizadas no momento político em que escrevera Raízes, em palestra de 1967, Holanda proporia: "não deixa de ser um fato que muitas providências adotadas pelo regime que se inaugura em 1930 se acharam inscritas nos mais autênticos padrões democráticos. É inegável, por exemplo, que por meio dessas providências são convidadas a atuar na vida pública nacional largas camadas outrora adormecidas, tanto que, entre 1930 e 1955, chega a decuplicar-se o eleitorado, ao passo que mal duplicará a nossa população" (HOLANDA, 2008, p. 632). Porém, seguia 
considerando tais mudanças bastante limitadas: e insistia que o próprio acesso ao voto, no Brasil, seguia considerado como supérfluo, já que se difundia a visão do presidente como "o homem chamado pela Providência a guiar a nação na crise que esta atravessava"; do que resultou que as massas foram "conservadas (...) em estado de menoridade ou de imaturidade" (Ibidem).

Para Gamio, a Revolução efetivamente havia sido um marco divisório entre um momento da história mexicana em que prevalecia um grupo específico, e um novo momento, no qual tenderiam a prevalecer as necessidades e interesses da maioria antes explorada. Assim, consta em Forjando pátria:

Se procuró de continuo que la vida política de quince millones de almas, estuviese consagrada a conservar rico y poderoso al pequeño grupo de pulpos políticos que paralizaban el desarrollo nacional. El campo de la política, que como hemos expuesto, se había transformado en charca deletérea, fue saneado por la Revolución (GAMIO, p. 143).

Vasconcelos, em Ulises criollo, apresentou um raciocínio semelhante ao de Gamio. Compreendendo a Revolução como os processos desenrolados entre 1910 e 1913; e que eles haviam sido "traídos", revertidos, descumpridos pelos chefes no poder a partir de então, ele defendeu a preocupação de Madero com os interesses das massas. Para esses ateneísta as propostas de Madero iam, pois, ao encontro dos anseios populares mais legítimos: "Él, que era um creyente del pueblo, un enamorado de sus entusiasmos y epopeyas, reconocía en aquella música gloriosa aventura reciente del pueblo mexicano" (VASCONCELOS, p. 492).

Enrique Krauze é um dos pesquisadores que, nesse sentido, não pode deixar de ser mencionado. Ele nos instiga a refletir criticamente sobre as versões que consideram a Revolução como resultado de iniciativas individuais/ de grupo, em última instância elitistas, a começar pela atuação de Madero. E nos pergunta: “¿Qué habría pasado si Madero, en vez de optar por las armas, hubiese persistido en la vía pacífica? Era posible” (KRAUZE, 2010). Senão, vejamos:

Madero, se prontificando a enfrentar institucionalmente Díaz, conquistou amplo apoio; mas Díaz firmou o pé. Lembram Camín e Meyer que então se mobilizaram, tensamente insatisfeitos, contrariados, em torno de Madero, diversos grupos: profissionais liberais, intelectuais, classes médias urbanas, e ainda camponeses, operários, rancheros e caudillos com força local mas até então sem grande expressão política no âmbito da federação (CARMÍN; MEYER, p. 33). Daí em diante, pois, Madero talvez tenha deixado de ter muita escolha, no que diz respeito à sua ação: era de se prever que rebeliões fossem ocorrer de qualquer maneira, lideradas por ele ou quaisquer outras forças políticas. Madero recorreu às 
armas para mobilizar a retirada de Díaz do governo; de maneira que, em 1911, quando Madero se tornou presidente legítimo, o velho ditador, expulso do país, teria lastimado: "Libertaram o tigre" (CARMÍN; MEYER, p. 37).

Fuentes destaca quatro líderes que, ao menos até o início da década de 1920, lutaram paralelamente numa mesma direção: Emiliano Zapata, Pancho Villa, Álvaro Obregón, e Venustiano Carranza. Conforme o escritor, enquanto os dois primeiros defendiam questões agrárias e proletárias, e eram mais radicais, parecia claro que os demais defendiam interesses das classes médias urbanas, e foram mais conservadores.

Segundo Fuentes, quando a deposição de Huerta se consolidou, e a convicção de que o Porfirismo era regime não mais resgatável se generalizou, era já patente a inviabilidade de que os quatro homens acima citados, todos eles, entrassem em um acordo para compor um governo comum (FUENTES, 2010).

O historiador John Womack hoje sugere que até mesmo não conviria classificar as movimentações militares e político-administrativas de princípios dos novecentos, no México, como revolucionárias, sobretudo porque não teriam partido de iniciativa popular. Para esse pesquisador, a chamada "Revolução Mexicana" corresponderia a uma série de enfretamentos e tomadas de decisões entre líderes; a medidas administrativas com alcance social restrito, e pautadas em interesses imediatistas e superficiais. "As grandes questões foram as de Estado. Por conseguinte, o assunto não é mais tanto a revolução social quanto a administração política" (WOMACK, p. 108).

Quando aos "peones" de La hacienda, o famoso conto do estridentista Javier Icaza, na visão de Brushwood, são postos em segundo plano, como uma bela paisagem, que no entanto não chega a imprimir contornos a ação dos personagens das camadas mais altas (BRUSHWOOD, p. 163-164). Na visão de Martínez, são puros, estão alheios ao ódio do antagonista e por isso logram, de certa maneira, constituir um projeto de luta; mas é um projeto um tanto difuso - "no significa nada para la administración revolucionária" (MARTÍNEZ, p. 227).

Mijangos lembra, então, que, na década de 1920 a interpretação de Guzmán também apontava a força de uma elite política, sobre as massas, ao longo do processo revolucionário: em La sombra del caudillo, o Estado apareceria como simples lugar de disputa entre interesses particulares (MIJANGOS: 103).

Vejamos o que a leitura de La sombra del caudillo nos revela. Em tal obra, todo o tempo, os chefes, se dizendo revolucionários, creem poder manipular a massa, dirigir seu gosto e suas escolhas; porém, ali também fica claro que essa não era uma tarefa fácil. A 
manipulação se dava mas não de forma tão simples e natural, pois se desenrolava dos gabinetes do governo em direção à rua, ao público, contando com a algazarra, a exaltação, os gritos e as ovações do coletivo; e incluía, assim, em sua dinâmica, uma parcela de aleatório.

Daí que o personagem principal do livro de Martín Luis Guzmán declare ironicamente:

Nos consta a nosotros que en México el sufrágio no existe: existe la disputa violenta de los grupos que ambicionan el poder, apoyados a veces por la simpatia pública. Esa es la verdadera Constitución Mexicana; lo demás, pura farsa. Pero (...) nuestras mismas disputas tienen sus reglas y son, en medio de todo, susceptibles de cierta decencia (GUZMÁN: 191).

Para Guillermo Hurtado, nesse sentido, o processo revolucionário desembocou, com a chegada de Carranza à presidência, em uma política que efetivamente mesclava/ conciliava diversas perspectivas: algo de radical, além de algo de liberal e conservador (HURTADO, p. 51). Knight pondera que a Revolução pode ser considerada, portanto, de alguma maneira, como uma "competencia por el poder político entre fuerzas rivales", que "lleva a una soberanía múltiple" (KNIGHT, p. 11). A respeito do poder "maximo" de Plutarco Elías Calles, escreveu Tzvi Medin: "la lucha entre diferentes facciones existentes era imposible de evitar”, diz Medín (MEDIN, p. 74).

Camín e Meyer lembram que continuou havendo dissidências consideráveis ao poder oficial, federal, no caso, agora, consubstanciado na figura dos presidentes sonorenses. Contam-nos, por exemplo, que, pelo território nacional, vários chefes criaram “o equivalente a feudos independentes em seus estados de origem e temiam o retorno do México a uma forte autoridade central"; e nos dão como exemplo o estado de Veracruz, onde se deu um governo de propostas próprias, para o qual, como vimos, trabalharam os estridentistas (CAMÍN; MEYER, p. 71).

Conforme Medín, Calles teve que lidar, como Jefe Maximo, com diferentes forças, tal como, por exemplo, os obregonistas, aborrecidos com o assassinato de seu líder, e com o descaso do governo no que diz respeito à punição dos culpados. Teve que lidar, também, com o fato de que esse grupo apresentava um racha, entre militares e civis, cujos interesses por vezes eram bem distintos (MEDÍN, p. 31). Havia ainda os camponeses, liderados pelo deputado Marte R. Gómez (Idem, p. 34). E os operários vinculados à CROM, e seu chefe Luis Morones, de quem Calles era íntimo (Idem, p. 33).

Ademais, o grupo que controlou o Estado dito "Revolucionário", a partir da chegada de Obregón ao poder, e sobretudo após a sua morte e o advento do Maximato, se caracterizou por outras personalidades expressivas. 
Esse é o caso de Emilio Portes Gil - legislador influente, próximo a grupos camponeses e operários, e inimigo público de Morones: dois problemas para el Jefe Máximo.

Perspicaz, quando da morte de Obregón Calles decidiu indicar Portes Gil à presidência provisória, enquanto se organizavam novas eleições; e desagradar ao amigo sindicalista. A ideia de Calles, conforme Medín, era não permitir que Portes Gil fortalecesse sua imagem durante uma campanha, de maneira a competir com a sua. Era também, empoçando Portes Gil interinamente na presidência, impedi-lo de acessar o cargo para um mandato completo, de seis anos.

Todavia, deve-se ter em mente: ainda que a chegada de Portes Gil ao governo tenha sido claramente influenciada por Calles, ele fez questão, todo o tempo, de minimizar a importância da opinião do Jefe Máximo (Idem, p. 38). Fez questão de apresentar um programa de ação bem particular, que em determinados pontos se distanciava do programa callista. Ele defendeu, por exemplo, que o Estado revolucionário procedesse a expropriação de consideráveis extensões de terra, para desagrado de Calles, que quanto a isso advogava pela moderação. Sob o argumento de que - hostil a Morones e então, aparentemente, certos círculos de operários - precisava contar com largo apoio dos camponeses, tal presidente convenceu, por fim, o Jefe Máximo, e avançou na reforma. Repartiu mais de um milhão de hectares (Idem, p. 60).

Outros importantes e autênticos feitos de Portes Gil como presidente, diz Medín, foram a resolução da questão cristera, e a já mencionada autonomização da Universidade Nacional.

Ademais, Medín sublinha que quando deixou o posto de presidente da república, Portes Gil não deixou de influenciar, de certa maneira, os destinos da política nacional; ou ao menos estabelecer diversos obstáculos à total hegemonia de Calles. Como novo diretor do Partido Nacional Revolucionário, se esforçou por impor sua voz ao presidente eleito, escolhido/indicado por Calles, Pascual Ortiz Rubio. Segundo Medín, Portes Gil ajudou a criar um mal estar tal, para o novo governo, que resultou na renúncia o governante michoacano (Idem, p. 91 e 113).

Ante à força política de Portes Gil, Calles teria aprendido algo: para evitar maiores dissidências internas, então, sim, patentes, seria mais interessante investir em simulacros de presidentes, mais fáceis de se manipular, figuras, afinal, mais débeis politicamente.

Foi partindo dessa lógica que ele teria optado por sugerir Ortiz Rubio como novo presidente. Como nos lembra Medín, esse se encontrava afastado do México há alguns anos, 
como embaixador mexicano no Brasil, e, portanto, parecia não dispor de base de sustentação política alternativa à que o Jefe Máximo estaria disposto a lhe garantir (MEDÍN: 43).

$\mathrm{O}$ fato de ter chegado à presidência eleito, mas claramente como designado por Calles, contribuiu para que Ortiz Rúbio enfrentasse uma série de ironias, ao longo de sua administração. O fato de ser um homem relativamente célebre da política revolucionária, agravou a crise. A somar, sofreu um atentado que lhe deixou com uma deformação na boa: sentia medo, sentia-se humilhado. Renunciou.

Daí então, el Jefe Máximo seguiu a determinação de escolher para presidente um homem inexpressivo, mas agora, com a renúncia de Ortiz Rubio, optou por alguém que não tivera uma participação considerável na fase tão icônica dos combates revolucionários; um administrador, capaz de organizar a instituição do Estado e implantar os projetos de desenvolvimento callistas, sem mais. Foi assim que Abelardo Rodriguez chegou à presidência.

Há o registro de um de seus discursos que ficou muito famoso, no qual ele definiu seus propósitos como governante; aqui transcrevo um trecho: "Insisto en que nunca fui político y en que si acepté el cargo de presidente sustituto de la República, fue porque tenía la seguridad de nivelar el presupuesto y poner en orden la administración del gobierno. Para lograrlo, me propuse permanecer al margen de la dirección política, dejando esa actividad en manos de políticos" (Idem, p. 122-133).

Medin se refere, ainda assim, à insistência dos presidentes do Maximato e de Calles, na primeira metade da década de 1930, em inserir, nos discursos oficiais, a importância das massas no desenvolvimento e ordenamento da nação; é o que o historiador denomina "era constructiva" da Revolução. Como exemplo, segue a transcrição de trecho de um discurso proferido por Ortiz, no ano de 1930:

nuestra obra no es, como planes puramente políticos, propia para dividir las
opiniones y para fomentar la lucha de las pasiones. Fomentará la armonía y
la inteligencia de todas las fuerzas nacionales. En ella podrán colaborar, con
la misma intensidad, el hombre de estudios que el obrero. En ella tendrán
una función igualmente importante el rico y el pobre (Apud. MEDÍN, p.
117).

Dessa visão mais técnica, resulta a chegada de Lázaro Cárdenas ao poder, justamente no ano em que Ramos publicava El perfil; também por indicação de Calles. Como nos demonstra a análise de Rafael Pavani, os discursos do novo presidente replicam a mesma visão de Estado empresarial e legalista. 
Todavia, como temos acompanhado, há, então, o fortalecimento de uma tendência ideologicamente radical, no México, de maneira que, diferentemente de Rodríguez, Cárdenas romperá com o Jefe Máximo, e promoverá um dos governos que mais promoveu benefícios sócias e econômicos às massas populares, daquele país.

De minha parte, proponho, então, que, como a Revolução, no México, enquanto cardápio de símbolos de coesão social, remetia ao popular, ao coletivo, à massa, os líderes não podiam simplesmente lançar mão de um discurso em defesa de um Estado objetivo, legal, profissional, separado da coletividade. Se seguiam dizendo-se "revolucionários", mesmo que "institucionais", tinham que remeter a isso. Tinham que incluir o dinamismo e popular, mesmo que apenas circunstancialmente e de forma limitada, em suas performances.

Ora, quando Ramos escreve El perfil estava na presidência o senhor Rodriguez, e a força de Calles parecia ainda inabalável. Pode se dever a isso, portanto, sua visão da dinâmica revolucionária como essencialmente cerrada nas mãos de um grupo relativamente coeso; da história mexicana como direcionada por poucos, sem considerar a diversidade de intenções e as intenções das massas; de que a política, no México, era atividade desenvolvida por e para poucos.

Se comparada às reflexões de Gamio, que havia focado os primeiros anos da Revolução, como essencialmente populares, a interpretação de Ramos destoa. Se comparada à de Vasconcelos, podemos observar algumas similitudes: já que ambos consideraram não apenas as movimentações das massas (no caso do ateneísta, mesmo sob o controle de Madero) como expressão de interesses gerais; que se iam perdendo com o tempo e a chegada dos sonorenses ao poder.

Quanto ao literato mexicano, nesta seção abordado, quer dizer, Guzmán, pode-se propor que o ensaio de Ramos replica sim não propriamente a defesa de um sentido mais ou menos elitista da Revolução, e sim, mais uma vez, da tensão entre teoria e prática, que teria caracterizado a dimensão popular do processo revolucionário: a crítica da encoberta tensão entre os discursos que, na fase de institucionalização da revolução, incluem os populares, e prática, na qual as elites se esforçam por anulá-los.

Tanto num caso como n'outro, portanto, a escrita de Ramos em El perfil se afasta do que os críticos consideram a respeito de uma suposta "responsabilidade" pela conformação de uma simbologia nacional alienada e acrítica; e pela proposição da Revolução, como um todo, como um projeto autenticamente, largamente, popular.

É uma nota que se observa também no texto de Holanda. Porque, em Raízes, ele difere de Freyre e de representantes do modernismo brasileiro como o grupo verde-amarelo, ao 
defender que a política brasileira se fizesse efetivamente de forma mais plural; e não apenas de forma acomodada e cordial ou de forma impositiva, por um Estado forte, centralizador e paternalista.

Cabe dizer, por fim, que essa seção de faz introdutória: na próxima avaliarei com maior minúcia tanto a teoria e a prática dos Estados ditos revolucionários/pós-revolucionário no Brasil e no México, no que diz respeito à concessão de benefícios materiais às massas; na teoria e na prática, para intelectuais e políticos brasileiros e mexicanos. 


\subsection{Democratização do acesso a benefícios materiais}

O objetivo desta seção é avaliar o acesso de classes menos favorecidas a benefícios materiais, após a Revolução de 1930, no Brasil, e a Revolução Mexicana. E, é claro, a maneira como Ramos e Holanda, em Raízes e El perfil, abordaram e/ou se desviaram de abordar o lugar histórico-social, e a necessidade de se operar uma efetiva transformação nas condições reais de sustento desses grupos.

Aqui trabalho a noção de "benefícios materiais" vinculada a duas outras: a de direitos (garantidos por lei), e a desenvolvimento nacional; uma noção abstrata do que deveria ser obrigação do Estado fornecer, e uma base econômica e institucional imprescindível para que se viabilizassem melhorias básicas nas condições de vida de parcelas carentes das populações brasileira e mexicana.

Cabe pontuar, então, que os mencionados ensaios de Holanda e Ramos não são sistemáticos ou mesmo explícitos na abordagem de tais questões. Tanto que, no que tange a Raízes, foi lido por Dante Moreira Leite - conforme vimos no capítulo anterior - como um livro que focava o comportamento das elites, e deixava um tanto de lado os procedimentos, os modos de ser, os anseios de classes amorfas, exploradas.

É verdade que Holanda pouco aborda das lutas e ganhos recentes, obtidos sobretudo por operários e demais trabalhadores urbanos, no Brasil republicano. Desde o findar do século XIX, determinados movimentos, como a modernização, o incremento da urbanização, o avançar do capitalismo, novas oportunidades se apresentavam (SCHWARCZ, 2012, p. 21).

Ás vésperas da Revolução de 1930, porém, conforme Lilia Mortiz Schwarcz, o Brasil passava a enfrentar um "processo de queda social", um "processo de achatamento social"; quer dizer, crise de dimensão não apenas econômica, como social e moral, e, afinal, políticoinstitucional (Idem, p. 25).

Ademais, como lembra essa historiadora, a "civilização", com seus adventos materiais, tecnológicos e logísticos, alcançava poucas regiões da nação (como a capital, Rio de Janeiro, e a progressista São Paulo):

Não por acaso, o jornal republicano Província de São Paulo (o futuro $O$ Estado de São Paulo) elegeu a frase 'O Brasil civiliza-se' como mote de sua linha editorial e criou uma seção especialmente dedicada ao tema. A frase havia sido escrita pelo colunista social Figueiredo Pimentel, na seção 'Binóculo', publicada na Gazeta de notícias, e valia, em princípio, só para o Rio de Janeiro. Mas a frase pegou e se disseminou pelo território nacional. Entretanto, o incremento urbano se deu apenas em algumas grandes cidades (Idem, p. 42). 
Schwarcz lembra ainda que, mesmo nesses núcleos, a urbanização implicava claros benefícios apenas a algumas parcelas da população; o "embelezamento" das cidades, por exemplo, se fez tanto no Rio de Janeiro como em São Paulo às custas da expulsão e de mãos tratos aos pobres deselegantes (Idem, p. 47). O processo de fazia muito sob a tal tensão entre teoria e prática, e de falseamento, de máscara, tantas vezes aludida ao longo desta Tese: "“De uma hora para outra, a antiga cidade do Rio de Janeiro desapareceu e outra surgiu como se fosse obtida por uma mutação de teatro. Havia mesmo na coisa muito de cenografia', registrou um sensível Lima Barreto, em 1908” (Idem, p. 271).

Com a chegada de Vargas ao poder, como temos acompanhado, alguns direitos foram oficializados; por meio de leis eleitorais, trabalhistas, educativas.

O autor de Raízes não se refere claramente a nada disso. E seu amigo e leitor, Antonio Candido, pontuaria, alguns anos depois, que os avanços empreendidos até então tinham sido de fato pouco notáveis:

Comparada com a de antes a situação nova representou grande progresso, embora tenha sido pouco, em face do que se esperaria de uma verdadeira revolução. Se pensarmos no 'povo pobre' (como diria Joaquim Manuel de Macedo), ou seja, na maioria absoluta da nação, foi quase nada (CANDIDO, 1983, p. 34).

Maria Odila Leite da Silva Dias sugere, a propósito, que "quando escreveu Raízes do Brasil, ainda mal se desencadeara o processo de industrialização e de urbanização, que transformou drasticamente as perspectivas da sociedade brasileira como um todo" (DIAS, 1998, p. 22).

Eugênio destaca, porém, que em Raízes efetivamente se vislumbra que a possibilidade de transformação para o Brasil estaria justamente não nas mãos de uma elite ilustrada e corrompida, mas dos trabalhadores, mais espontâneos e autênticos (EUGENIO, 2010).

Em certa passagem Holanda transcreveu uma reflexão de Herbert Smith, usada para pontuar que as classes mais pobres do Brasil, carregando em si algo do aventureiro, do semeador e do homem cordial, se distinguiriam mais pela espontaneidade do que pelo desleixo. Cito a passagem, a título de ilustração:

Não ouso afirmar que, como classes, os operários (...) sejam superiores aos cavaleiros e aos grandes negociantes. A verdade é que são ignorantes, sujos e grosseiros; nada mais evidente para qualquer estrangeiro que os visite. Mas o trabalho dá-lhes boa têmpera, e a pobreza defende-os, de algum modo, contra os maus costumes (Apud. HOLANDA, 1999, p. 181).

Ramos constrói o tipo ideal "pelado", que parece ser, em essência, um proletário. Mas suas referências ao fato de pertencer a uma classe miserável são superficiais. E, ademais, ele 
faz questão de pontuar que a aludida categoria remete a cidadãos mexicanos de todos os estratos da sociedade mexicana (RAMOS, p. 87).

Tal como no caso do Brasil, conforme Camín e Meyer a Revolução não eclodiu em um México marcado pelo mais absoluto atraso econômico e tecnológico. Suas cidades e indústrias cresciam, a oferta de emprego para os operários também, a produção começava a se modernizar, as exportações dos produtos agropecuários ganhavam vulto, meios de transporte e comunicação mais ágeis e eficientes encurtavam as distâncias entre aquele país tão marcado pelos regionalismos (CAMÍN; MEYER, 2000).

Segundo Sarmiento, Díaz havia promovido desenvolvimento econômico e técnico: trouxe investimento estrangeiro, arbitrou para que fosse aplicado em áreas-bases para a industrialização, garantiu notável infraestrutura e equilíbrio político para que os investidores europeus e norte-americanos seguissem se sentindo confortáveis para trazer capitais para o México. Isso resultou, para a população, em mais empregos, melhorias nas condições de vida, e um notável aumento demográfico (SARMIENTO, 2010).

Mas o desenvolvimento promovido por Díaz se deu de maneira desordenada, gerando inflação, tornando a economia nacional vulnerável, destruindo a tradicional economia camponesa.

Conforme Gamio, em Forjando pátria, o México de princípios do século XX não era plenamente atrasado; havia bolsões de riqueza, desenvolvimento, e progresso técnico, e era hora de fazer com que tais condições se generalizassem; fazer com que o país unido pudesse efetivamente progredir. Lê-se, ali, então: "unas cuantas familias vivieron en la abundancia y otras, las más, sufrían el tormento del hambre, de la desnudez, del abandono intelectual, claro es que de su unión artificial no pudo resultar un conjunto armónico, no pudo surgir una nacionalidad" (GAMIO, p. 16).

Para Vasconcelos, quando a Revolução começou o México não era um país atrasado. A Revolução não vinha, assim, para promover desenvolvimento. Ela vinha repartir os ganhos. Escreveu, em Ulises criollo: "El porfirismo creyó realizado el progreso porque llegava a México um automóvil, pero en las casas de la [capital] se seguía guisando com carbón vegetal como en los tiempos de Monctezuma" (VASCONCELOS: 483).

De acordo com a análise de Paz, herdeiro dos ateneístas, o "fáctil" desenvolvimento financeiro e tecnológico porfirista serviu para sustentar perspectivas políticas enganosas, e a sedimentar as diferenças sociais.

$\mathrm{Na}$ aparência, Díaz governa inspirado pelas ideias em voga: acredita no progresso, na ciência, nos milagres da indústria e do livre comércio. Seus 
ideais são os da burguesia europeia. É o mais ilustrado dos ditadores hispano-americanos e seu regime lembra, às vezes, os anos da belle époque na França. (...) A aristocracia mexicana é uma classe urbana e civilizada". Todavia, "a outra face da moeda é muito diferente. Estes grandes senhores amantes do progresso e da ciência não são industriais nem homens de empresa: são proprietários de terra, enriquecidos pela compra dos bens da Igreja ou pelos negócios públicos do regime. Em suas fazendas, os camponeses vivem vida de servo (PAZ, p. 118).

Quando abordaram o desenvolvimento do México durante o Porfirismo, pois, os ateneístas tenderam a considerá-lo e a fundar uma tradição de interpretação do Porfirismo como limitado ou ilusório, material e elitista; e a defender outra concepção de "progresso", fincada sobre parâmetros mais humanos, e que acessasse o espiritual e geral. E Ramos, com seu Perfil, certamente se insere nessa tradição.

Porém, devemos fazer uma distinção: em alguns - ou grande parte - dos textos produzidos pelos atenenses que aqui considero, a cojuntura abordada era diferente daquela na qual Ramos se localizava, com a qual dialogava, queria entender, criticava, em El perfil. Eles se voltaram contra o Porfirismo; e Ramos se voltou contra o que via de Porfirismo na patente política econômica; quer dizer, no projeto callista.

É contra Calles que Ramos desfere o seguinte argumento:

Si la escuela sirve esclusivamente a la ténica material, quiere decir que prepara a los indivíduos para ser más facilmente devorados por la civilización; La educación debe concebirse, al contrario, como un esfuerzo de la vida misma que se defiende contra una civilización, la cual aparentemente prepara muy bien a los hombres para vivir, convirtiéndolos en autómatas perfectos, pero sin voluntad, ni inteligencia, ni sentimiento; es decir, sin alma (RAMOS, p. 142).

Quanto à ideia de luta por benefícios materiais, disse há pouco, tal como Holanda Ramos não as aborda. Ambos os autores, em seus ensaios mais famosos, falam em progresso material em desprestígio do humanístico, em injustiça social e política, mas não tratam especificamente das carências materiais de camponeses e camponeses. Suas análises ficam restritas ao que então se atribuía como problema cultural, psicológico, social dessas classes; descartando alguns, e reiterando outros.

Quanto ao campo, podemos vislumbrar uma distinção: Holanda confere a tal aspecto da história contemporânea brasileira uma importância bastante maior que Ramos.

Ramos não menciona sequer uma vez os nomes de Villa e de Zapata. E não chega a considerar a questão da terra; ou ao menos a importância do meio rural nas relações políticosociais remanescentes, ao longo da história do México. Grande parte da tradição de estudos sobre a Revolução Mexicana, porém, a considera uma revolução tipicamente rural. 
No que diz respeito a Holanda e à Revolução de 1930, no Brasil, é curioso que as problemáticas relativas ao universo rural apareçam enfatizadas em Raízes, mas tenham sido borradas, nos discursos de Vargas.

Esse foi, aliás, um enfoque que os modernistas, Bomfim, Paulo Prado, Freyre e Holanda conferiram a suas interpretações históricas, psicologizantes, culturais, sociológicas, das condições do Brasil moderno: para todos eles, na modernidade o Brasil seria ainda bastante caracteristicamente rural.

Quanto aos modernistas, cabe lembrar as viagens feitas por Mario e Oswald, pelas cidades históricas mineiras; e o trabalho de catalogação antropológica feito por Mario, no final da década de 1920, pelas regiões Nordeste e Norte do Brasil. Segundo a visão Ricardo, modernista que tanto dialogou com Holanda, o "real” brasileiro vivia no campo: "Só quem não viajou pelo interior, onde há mais Brasil do que nas cidades, não terá observado esse costume, próprio do brasileiro que nasceu assim e que não muda mesmo" (RICARDO, 2006: 377).

Para Paulo Prado, em Retrato do Brasil, o carioca - cidadão de capital, cidadão de metrópole - se diferenciava do brasileiro em geral, sempre triste, por ter a experiência de vida marcada pelo urbano, que deformaria o que é típico, e nivelaria os procederes em uma forma só, não necessariamente alegre, mas vazia de vida: seria o carioca "já produto de cidade grande e marítima, em contato com o estrangeiro e entregue ao lazaronismo do ambiente" (PRADO, 2001: 143).

Já para o marxista Caio Prado Junior, em Evolução política do Brasil, toda produção de riqueza ou bem cultural era "reflexo fiel de sua base material: a economia agrária" (PRADO: 23).

Indo mais longe que os demais, em um Posfácio a Brasil nação, datado de 1931, Bomfim afirmou que, para ser uma "legítima revolução renovadora", a chamada "Revolução de 1930" deveria atender a duas questões prementes: o acesso de outros grupos ao poder, e o debate sobre a questão da terra (BOMFIM, 1998, p. 696).

De fato, a atuação de Vargas, no atendimento às necessidades dos trabalhadores brasileiros, não alcançava o campo: no âmbito rural as relações coronelistas se mantinham vivas; a legislação trabalhista implementada não regularizava a situação dos empregados de fazendas; e o governo nem sequer cogitava a possibilidade de uma reforma agrária.

De acordo com Alcir Lenharo, apenas com a chegada do Estado Novo, a partir de 1937, Vargas começa a pensar explicitamente a situação no campo, e propõe o chamado Código Rural. Embora não tenha saído do papel, tal texto colocava em discussão alguns temas 
importantes, sempre retomados, daí em diante, como a definição do que vinha a ser "empregado rural" (assalariados, permanentes ou não, em estabelecimentos agropecuários), e regulamentação das relações de trabalho em engenhos e empresas extrativistas (LENHARO, 1986, p. 85).

Leonilde Sérvolo de Medeiros acrescenta que, ao contrário do que ocorreu para o ambiente urbano, para o qual coube uma legislação que previa o direito de associação sindical para trabalhadores e empregadores, em estruturas separadas; para o ambiente rural, por força dos empresários do campo, oficialmente as associações só poderiam se dar de forma mista (MEDEIROS, 2010, p. 115).

João Pedro lembra, por fim, em entrevista de 1997 à revista Estudos avançados, que a reforma agrária, como demanda dos tenentistas, foi negligenciada por Vargas no pós-1930; lembra, que, embora esse tenha sido o primeiro presidente brasileiro a considerar o assunto oficialmente, se teria limitado a promover o que o militante chama "colonização" - fixação de pequenos proprietários de terras, em colônias agrícolas (STÉDILE, 1997: 33).

Schwarcz destaca que Holanda lamentava, que, se por um lado as oligarquias rurais eram ainda bastante fortes no Brasil, por outro a burguesia urbana e industrial era ainda significativamente frágil e muito dependente (SCHWARCZ, 2008: 85). Lemos em Raízes que aos "elementos empreendedores do país" faltaria "capacidade de livre e duradoura associação" (HOLANDA, 1999: 59).

Desde o século XIX, consta em Raízes, essa burguesia até seria capaz de "grandes iniciativas progressistas", mas tais iniciativas deveriam ser consideradas "atitudes peculiares", ou mesmo "improvisações", porque raras e incompatíveis com a mentalidade arcaica das elites proprietárias de terra (HOLANDA, 1999: 79). Para Schwarcz, ao ver de Holanda "a cidade seria uma extensão do campo, carregando vícios e marcas num continuum quase constrangedor" (SCHWARCZ, 2008: 85).

Alan Knigth afirma que muito do que teria mobilizado os mexicanos comuns a apoiarem os chefes ditos "revolucionários" foi justamente o anseio por possuir um rincão de terra onde plantar seu sustento, independente. A Revolução teria correspondido, assim, ao ver desse pesquisador, a uma ampla mobilização de setores rurais, que passou a considerar o acesso à terra como um direito primordial, e nisso foi, de certa maneira, ouvido pelos poderosos (KNIGHT, p. 22).

Afinal, esta foi a principal bandeira levantada por Zapata: enquanto os aliados de Madero gritavam "Sufrágio efectivo y no reelección!", os bandos zapatistas exigiam “Tierra y Libertad". 
Gamio, em Forjando pátria, de 1916, apresentou não só um elogio à repartição das terras, como uma clara defesa da estrutura comunal, ejidatária. Argumentava:

La Revolución ha iniciado ya la devolución de tierras que fueron arrancadas a los indígenas y procura legitimar la posesión de las que actualmente tienen. Sin embargo, hay que hacer más, hay que reconsiderar lo que empíricas leyes pretéritas establecieron; hay que derogar la prohibición impuesta a las comunidades en materia de propiedad y explotación de intereses. Y conste que lo propuesto no constituye tendencia retrógrada, pues experimentalmente puede comprobarse la conveniencia que para las agrupaciones que discutimos ofrece el sistema comunal de intereses" (GAMIO, p. 322).

Nesses termos, tal autor revela total sintonia com o que viria endossar, um ano depois, o novo texto constitucional. Transcrevo aqui, a título de ilustração e verificação, o parágrafo sétimo do célebre artigo 27, que contempla os interesses dos grupos indígenas, e seus tradicionais hábitos de cultivo da terra. Constava lá que através da Constituição de 1917 o Estado mexicano reconhecia

la personalidad jurídica de los núcleos de población ejidales y comunales y se protege su propiedad sobre la tierra, tanto para el asentamiento humano como para actividades productivas"; e que "la ley protegerá la integridad de las tierras de los grupos indígenas", podendo implicar "la restitución de tierras, bosques y aguas a los núcleos de población (GARCILADIEGO DANTAN, 2005: 102).

Presidente a partir de 1920, Obregón reafirmou tais demandas, e criou a lei que regularizaria as repartições (ARREOLA CORTÉS, p. 57).

Segundo Knight, outra mudança importante, processada durante a Revolução, foi o combate à peonaje, uma espécie de servidão por dívida bastante comum no sul do México. Durante o porfiriato estabeleceu-se a seguinte relação entre os terratenientes e trabalhadores de suas haciendas: o consumo dos trabalhadores era restrito às mercadorias vendidas nas "tiendas de raya", que eram também de propriedade dos terratenientes; ora, o preço das mercadorias era tão extorsivo, que os trabalhadores não podiam pagar seus gastos inteiramente, com seus salários, e sempre deviam mais e mais aos patrões. Por vezes as dívidas chegavam a não ser jamais saldadas, e eram herdadas por outras gerações, mantendo famílias em dependência, e fixas no espaço da hacienda. O Estado Porfirista por muito tempo garantiu bases legais para tal costume. Mas na Revolução ele foi oficialmente proibido (KNIGHT, p. 24).

Para além das extensões de terra repartidas, Knight considera, então, a importância simbólica e política da hacienda colonial na dinâmica produtiva de toda a federação, naquela primeira metade do século XX, no México. E argumenta que, afinal, os terratenientes estavam 
perdendo espaço não apenas físico/geográfico, e consequentemente econômico, mas político. Assim, em meados da década de 1920, já não havia entre eles esperanças de que voltassem a usufruir de tantas vantagens, como no tempo de Don Porfírio (Idem, 23).

A luta dos camponeses, e a queda do poder inquestionável dos terratenientes não implicou, contudo, que o acesso a reais benefícios fosse viabilizado aos primeiros.

Alguns autores mais recentes efetivamente sugeriram, logo, que, na prática, a Revolução Mexicana não correspondeu a uma revolução agrarista. Segundo Camín e Meyer, as divisões de terra foram, a bem da verdade, limitadas. Depois, o fluxo de repartição variou muito de presidente para presidente; e foi mais intenso no sul do país, onde os camponeses eram mais organizados e combativos. Além disso, muitas se deram em benefício de particulares, de familiares e amigos próximos, ou dos próprios chefes revolucionários (CAMÍN; MEYER, p. 89). Por fim, diz Jean Meyer Jr, a produtividade dos camponeses beneficiados pela lei foi baixa e pouco competitiva, porque eles não puderam contar com significativo apoio do governo (MEYER JR, p. 228).

Por isso o austro-americano Frank Tannebaum, em The mexican agrarian revolution (1929), apresentou a questão agrária como uma questão que urgia ser sistematicamente reconsiderada pelo Estado revolucionário institucionalizado. Sim, porque à época a grande maioria dos mexicanos, indígena ou mestiço (por etnia e tradição), seguia residindo no campo, atuando no setor primário; mas o governo até então pouco tinha feito pensando em sua tradicional economia rural.

Conforme Tannebaum, lembrando Gamio, se se considerasse a cultura nacional se perceberia que o braço mexicano deveria dedicar-se ao trabalho comunitário nos ejidos; trabalho conjunto e para o bem da coletividade. O sistema de haciendas, logo, para ele, parecia tão incompatível com a realidade nacional mexicana quanto qualquer outro sistema que não se baseasse nos ejidos (TANNENBAUM, 1929).

E o fato é que, diz Knight, a desmontagem da hacienda foi considerada essencial não apenas pelos camponeses, mas também pela classe média em ascensão, e abastados investidores. Tais setores, pensando à luz da história norte-americana, viam as grandes propriedades como um problema; e as propriedades de média extensão e produção familiar e associativa-capitalista como ícones de produtividade e desenvolvimento. Além disso, eram claros defensores da mão-de-obra assalariada; e a verdade é que mesmo os haciendados mais tradicionalistas passavam, pouco a pouco, naquele tempo, a sentir que parecia mais interessante expulsar os camponeses em dívida do que mantê-los (KNIGHT, p. 31). 
Ora, para os sonorenses, em geral, o ejido era anti-capitalista e anti-moderno, senão tão-somente anti-produtivo, e por isso pouco vantajoso para um México que pretendia e precisava crescer economicamente.

Vasconcelos, diferentemente de Gamio e Tannebaum, e tal como os presidentes sonorenses, revela-se, em Ulises criollo, pouco simpático à causa dos zapatistas. Foi defensor da revolução, mas de uma revolução da ordem, e da modernização do México, daí compreender que os seguidores de Zapatistas, em suas revindicações fincadas em tradição e expostas através de métodos radicais, fossem considerados um mal para a nação. Ora "victima de las intrigas que urdían los derrotados", ora "labriegos" insubmissos (VASCONCELOS, p. 445) desdobravam os conflitos revolucionários em complicados termos, a seu ver, contraproducentes. "El plan zapatista de ocupar fincas por la violencia y repartirla a los soldados, era el antecedente (...) de los apoderamientos de tierra (...). El Plan de Madero, en cambio, suponía una política de consecuencias progresistas" (Idem, p. 453).

O descaso de Vasconcelos em relação às problemáticas do campo, replicado por Ramos, em El perfil, parece ter sido bastante comum, pois a separação entre o universo rural e urbano, nas mentes mexicanas de princípios do século $\mathrm{XX}$, foram ironizadas por diversos dos mais interessantes intelectuais daquela conjuntura.

Mariano Azuela, em Los de abajo, por exemplo, apresente um cosmopolita Cervantes que não se consegue bem se enquadrar entre os provincianos revolucionários do bando de Demetrio; ele tenta, mas não pode se conformar com dos alguns hábitos e entendimentos daqueles sujeitos.

Já em México insurgente, de Reed, há uma divertida passagem na qual fica bastante claro que tampouco os camponeses combatentes deixavam de compreender os homens cultos, oriundos das cidades, como um tanto "exóticos". Nela, conta o jornalista norte-americano que alguém lhe afirmara duvidar que em seu lugar de origem houvesse um gado tão bom quanto o gado do norte do México; o jornalista, natural de Portland, contestou que lá não havia gado algum.

'O quê? Não há gado? Você quer me dizer que não tangem gado pelas ruas de lá? Nem ovelhas?' Eu disse que não. Olhou-me como se eu fosse um grande mentiroso; então, voltou os olhos para o chão e ficou pensando, profundamente. 'Bem - pronunciou, enfim - então não quero ir para lá!' (REED, p. 268-269).

Em texto publicado em 1925, por ocasião da morte de um de seus professores mais queridos, o científico michoacano José Torres Orozco, o próprio Ramos apresentou a alongada reflexão sobre a importância do universo urbano na conformação de mentes 
inovadoras. Ramos ali elogiava o antigo mestre, em vários aspectos, mas, num balanço crítico, atribuía ao provincianismo de Torres suas principais limitações filosóficas. Conforme Ramos, embora Torres tenha se oposto ao ditador Porfírio Díaz, se manteve sempre vinculado ao positivismo, num caso de - nas palavras do futuro autor de El perfil - "positivismo tardio", (RAMOS, 1970, p. 9). Então, sugeria:

La ciudad pequeña naturalmente reduce a proporciones minúsculas toda actividad del hombre. (...) El esfuerzo es menos intenso, por la poca acumulación, y escasa competencia. Los hombres en número corto se unifican mejor, (...) tendiendo siempre a la inmutabilidad. (...) [Sin embargo] la diferencia entre la mentalidad de provincia y la mentalidad de la capital no es solamente el ritmo, sino también de perspectiva. (...) El provinciano (...) difícilmente puede concebir que haya formas de pensamiento diversa a las que posee (RAMOS, 1970, p. 9-10).

Se compararmos Holanda e Ramos, temos, pois, que, enquanto o primeiro, em Raízes, considerou a espontaneidade como a contribuição maior dos populares, no Brasil, Ramos considerou uma dada maior espiritualidade. Ambos, assim, buscaram refletir sobre alternativas ao capitalismo em vigor, fundado num materialismo, num egoísmo, num sistematismo, um rigor, que rejeitavam.

Em seus modos de enxergar os trabalhadores, os homens pobres, de seus países, não foram, porém, saudosistas e românticos.

Na realidade, parecem ter compreendido - cada qual à sua maneira - que determinadas vivências dadas no universo do campo, no Brasil e no México, já não eram mais interessantes, e encarceravam um modo de ser "popular", espontâneo e humano, em relações pouco já, então, profícuas. Holanda apresentou uma crítica explícita, aos arcaísmos rurais brasileiros, tão notáveis no modo de agir político, contemporâneo, em nosso país. Já Ramos, lado a lado com intelectuais mexicanos que (ligados ou não a Calles) à época identificaram ruralidade e atraso, camponeses e tradicionalismo, optando por um silêncio desconfortável a respeito da luta pela terra, que tanto caracterizou os discursos sobre a Revolução Mexicana. 


\section{CONSIDERAÇÕES FINAIS}

O objetivo desta Tese era analisar como Sergio Buarque de Holanda e Samuel Ramos Magaña trabalharam a ideia de "revolução", e entenderam as possibilidades de uma revolução, respectivamente, no Brasil e no México, no início do século XX. Consideram-se, para tanto, os ensaios mais célebres desses dois autores: Raízes do Brasil e El perfil del hombre y la cultura en México, ambos publicados pela primeira vez na década de 1930, mas, como clássicos, tantas vezes lidos e ressignificados por distintas gerações.

Partindo de um dos grandes expoentes da História Intelectual, Dominick LaCapra, demonstrou-se que as metodologias ali trabalhadas - estruturação de tipos/ tipologias - e os conceitos ali propostos - sobretudo os conceitos de "homem cordial", de Holanda, e "pelado", de Ramos - indicam uma preocupação pontual com a crítica dos modos de pensar e ser do brasileiro e do mexicano contemporâneos, reais, nem sempre observada pela fortuna crítica, que prefere apresentar os ditos ensaístas, quando jovens, como ideólogos de um nacionalismo em última instância comprometido com os governos instituídos.

Firmou-se, pois, a intenção de ambos os autores analisarem as raízes de nossos modos de ser, e os perfis variáveis da cultura moderna, no Brasil e no México.

Partindo de um dos grandes expoentes da História dos Conceitos, Reinhart Koselleck, considerou-se, também, Raízes e El perfil e suas formas e noções fundamentais, em meio aos universos intelectuais brasileiro e mexicano; apontando semelhanças e distinções no que diz respeito à produção de outros ensaístas, e também à produção dos literatos de vanguarda.

Pontuou-se, destarte, que esses livros se encontram num meio-termo, entre volteios críticos produzidos por não-especialistas, e interpretações metodologicamente mais acuradas, consolidadas anos depois; e pontuou-se que seus autores compartilharam com a diversificada vanguarda literária brasileira e mexicana não tanto o desejo de elaboração de padrões de identificação nacional, como de crítica dos clichês de nacionalidade.

Daí, partiu-se para os usos que Holanda e Ramos fizeram do termo "revolução". Viuse, logo, que ambos assinalavam o fato de tal denominação ser atribuída a movimentos caóticos, violentos, de ruptura político-administiva, mas não necessariamente profunda e significativa. E viu-se que, para além desses momentos, notáveis no Brasil e no México, ambos entenderam que se estaria processando lentamente, de forma quase imperceptível (por vezes de maneira a avalizar pessimismos), alterações interessantes e radicais. 
Para o referido ensaísta brasileiro, essas alterações deveriam ser, elas sim, chamadas "Nossa Revolução"; já o ensaísta mexicano, apesar de apresentar uma interpretação semelhante acerca dos fluxos históricos contemporâneos, no México, não chega a repisar o vocábulo, já tão desgastado, em seu país.

Nesta Tese foram, assim, avaliados os debates então correntes a respeito das experiências contemporâneas de Brasil e México, e as contribuições de Holanda e Ramos para tais debates. Nesse percurso, vislumbrou-se que algumas de suas ideias se repetiam, na voz de outros ensaístas, literatos vanguardistas, e políticos, da época: a ideia de embuste, falseamento, encobrimento, e especificidade das problemáticas sociais, políticas e morais; dentre as quais a problemática revolucionária. E buscou-se demarcar como as análises propostas em Raízes e El perfil oscilam entre a denúncia das máscaras, e anseio de que se optasse, de que se trabalhasse por uma mais expressão política e cultural original.

Considerou-se, ainda, que, na análise das condições brasileiras e mexicanas, nas primeiras décadas dos novecentos, e das específicas potencialidades revolucionárias nesses contextos latino-americanos, foi comum a preocupação com as seguintes questões: (1) a irracionalidade e/ou o inconsciente como agente histórico; (2) o intelectualismo e a sistematização de projetos; (3) as condições de legalidade; (4) a personalidade de grandes líderes e o familismo; (5) o anseio por democratização política; (6) o anseio pela ampliação do acesso a benefícios materiais e/ou a oportunidades de crescimento econômico; (7) as especificidades do homem moderno nacional, brasileiro e mexicano.

Tais movimentações reflexivas - incluindo a da autora desta Tese - foram percorridas, afinal, por três tensões, particularmente evidenciadas por intelectuais latino-americanos, que pensaram e pensam a América Latina, e as revoluções na América Latina: as tensões entre teoria e prática, tradicional e moderno, nacional e estrangeiro. 


\section{BIBILIOGRAFIA}

\section{Teoria e método}

KOSELLECK, Reinhardt. Futuro passado: contribuição à semântica dos tempos históricos. Rio de Janeiro: Contraponto, 2006.

LACAPRA, Dominick. Repensar la historia intelectual y leer textos. In: PALTI, Elías José. El giro linguístico y la historia intelectual. Buenos Aires: Universidad Nacional de Quilmes, 1998.

MONASTÉRIO, José Ortiz. Raízes do Brasil e El laberinto de la soledad: uma comparación. In: MONTEIRO, Pedro Meira \& EUGÊNIO, João Kennedy. Sergio Buarque de Holanda: perspectivas. Rio de Janeiro: Eduerj, 2006.

SANTIAGO, Silviano. As raízes e o labirinto da América Latina. Rio de Janeiro: Rocco, 2006.

VARGAS, Everton Vieira. O legado do discurso: brasilidade e hispanidade no pensamento social brasileiro e latino-americano. Brasília: Fundação Alexandre Gusmão, 2007.

WASSERMAN, Claudia. Nacionalismo: origem e significado em Sérgio Buarque de Holanda, Samuel Ramos e Ezequiel Martinez Estrada. In: Revista Eletrônica da ANPHLAC. 2003. n. 3.

\section{Brasil e brasileiros}

AGUIAR, Flavio. A moldura e o espelho de Raizes do Brasil. In: DE DECCA, Edgard Salvadori. Pelas margens: outros caminhos da história e da literatura. Campinas: Unicamp, 2000. 
AGUIAR, Ronaldo Conde. O rebelde esquecido: tempo, vida e obra de Manoel Bomfim. Rio de Janeiro: Topbooks, 2000,

ALMEIDA, José Américo de. Antes que me perguntem. In: ---. A bagaceira. Rio de Janeiro, 2004 .

ALMEIDA, Manuel Antonio de. Memórias de um sargento de milícias. São Paulo: L\&PM editores, 1997.

ANDRADE, Mario de. Prefacio interessantíssimo. In: ---. Poesias completas. Belo Horizonte: Martins, 1980.

---. Macumaíma: o herói sem nenhum caráter. São Paulo: Martins, 1970.

ANDRADE, Oswald de. Manifesto Pau-brasil \& Manifesto Antropófago. In: TELES, Gilberto Mendonça Teles. Vanguarda europeia e modernismo brasileiro: apresentação e crítica dos principais manifestos vanguardistas. Petrópolis, Vozes, 2009.

---. Pau-brasil. São Paulo: Globo, 2003.

---. A utopia antropofágica. São Paulo: Globo, 1995.

ARRUDA, Marcos \& CALDEIRA, Cesar. Como Surgiram as Constituições brasileiras. Rio de Janeiro: FASE, 1986.

BANDEIRA, Manuel. Estrela da vida inteira. Rio de Janeiro: José Olympio, 1980.

BARBOSA, Francisco Assis. Raízes de Sergio Buarque de Holanda. Rio de Janeiro: Rocco, 1989.

BARRETO, Lima. Triste fim de Policarpo Quaresma. São Paulo L\&PM, 1998. 
BASTOS, Elide Rugai. Raízes do Brasil e Sobrados e mucambos: um diálogo. In: MONTEIRO, Pedro Meira \& EUGÊNIO, João Kennedy. Sergio Buarque de Holanda: perspectivas. Rio de Janeiro: Eduerj, 2006.

BELOCH, Israel Beloch \& ABREU, Alzira Alves de. Dicionário Histórico Biográfico Brasileiro pós 1930. Rio de Janeiro: Ed. FGV, 2001.

BERRIEL, Carlos Eduardo Ornelas. Tietê, Tejo, Sena: A Obra de Paulo Prado. Campinas: Papirus, 2000.

BEZERRA, Elvira. Ribeiro Couto e o homem cordial. In: Revista Brasileira. Rio de. Janeiro, julho/setembro de 2005. V. 11. N. 44.

BLAJ, Ilana e MALUF, Marina. Caminhos e fronteiras: o movimento na obra de Sérgio Buarque de Holanda. In: Revista de História. São Paulo: janeiro/junho de 1990. n.122.

BOMFIM, Manoel. América Latina: males de origem. Rio de Janeiro: Topbooks, 2005.

---. Brasil nação. Rio de Janeiro: Record, 1998.

BORGES PINTO, Maria Inez Machado. Urbe industrializada: o modernismo e a Paulicéia como ícone da brasilidade. In: Revista brasileira de História. São Pauylo, 2001. V. 21. N. 42.

BOSI, Alfredo. Prefácio. In: LEITE, Dante Moreira. O caráter nacional brasileiro: história de uma ideologia. São Paulo: Pioneira, 1983.

---. Um testemunho do presente. In: MOTA, Carlos Guilherme. Ideologia da cultura brasileira: 1933-1974. São Paulo: Editora 34, 2008.

---. Homenagem a Sergio Buarque de Holanda. In: ---. Céu, inferno: ensaios de crítica literária e ideológica. São Paulo: Editora 34, 2003.

---. Dialética da colonização. São Paulo: Cia das Letras, 1992. 
BOTELHO, André. Passado e futuro das interpretações do país. In: Tempo Social. São Paulo, 2010. V. 22.

BRANDÃO, Gildo Marçal. Linhagens do pensamento político brasileiro. In: Revista de Sociologia e Política. São Paulo, novembro de 2008. V. 16. N. 31.

BRUHNS, Hinnerk. O Conceito de Patrimonialismo e Suas Interpretações Contemporâneas. In: Revista Estudos Políticos. Rio de Janeiro, 2012. N. 4. V. 1.

BURKE, Peter. A história total. In: Folha de São Paulo. São Paulo, 23 de junho de 2002. Mais!

CALIGARIS, Contardo. Do homem cordial ao homem vulgar. In: Folha de São Paulo. São Paulo, 12 de dezembro de 1999.

---. Acusação sem endereço. In: Folha de São Paulo. São Paulo, 23 de janeiro de 2000.

CALIL, Carlos Augusto. Introdução a. In: PRADO, Paulo. PRADO, Paulo. Retrato do Brasil. São Paulo: Cia das Letras, 2001.

CANCLINI, Nestor Garcia. Culturas híbridas. São Paulo: Cia das Letras, 2005.

CANDIDO, Antonio. O significado de Raízes do Brasil. In: HOLANDA, Sergio Buarque de. Raízes do Brasil. São Paulo: Cia das Letras, 1999.

---. A visão política de Sergio Buarque de Holanda. In: --- (Org.). Sergio Buarque de Holanda e o Brasil. São Paulo: Perseu Abramo, 1998.

---. Sergio em Berlim e depois. In: Novos estudos. São Paulo, julho de 1982. N. 3.

---. Um verão, em Berlim. In: ---. Recortes. Rio de Janeiro: Ouro sobre Azul, 2004. 
---. Dialética da malandragem. In: ---. O discurso e a cidade. São Paulo: Outro sobre azul, 2010 .

---. A revolução de 1930 e a cultura. In: Novos Estudos Ceprap. São Paulo, abril de 1983. V. 2. N. 4.

CARDOSO, Fernando Henrique. Livros que inventaram o Brasil. In: Novos Estudos Cebrap. São. Paulo, 1993. N. 37.

CARONE, Edgard. Notícias sobre Brasilianas. In: Perspectivas: Revista de Ciências Sociais. São Paulo: Universidade Estadual Paulista, 1976. V. I. N. 1.

CARVALHO, José Murilo de. Forças Armadas e política, 1930-1945. In: A Revolução de 1930: seminário internacional. Brasília: Editora da Universidade de Brasília, 1982.

CASTRO, Conrado Pires de. Motivos ibéricos, pretextos literários. In: MONTEIRO, Pedro Meira \& EUGÊNIO, João Kennedy. Sergio Buarque de Holanda: perspectivas. Rio de Janeiro: Eduerj, 2006.

CAVALCANTI, Berenice. História e modernismo: herança cultural e civilização nos trópicos. In: MONTEIRO, Pedro Meira \& EUGÊNIO, João Kennedy. Sergio Buarque de Holanda: perspectivas. Rio de Janeiro: Eduerj, 2006.

CERQUEIRA, Marcelo Neder. As raízes do Brasil de ponta-cabeça e a saída do labirinto da solidão. In: Anais do XIV Encontro regional na ANPUH-RIO: memória e patrimônio. Rio de Janeiro: Unirio, julho de 2010.

COHN, Gabriel. O pensador do desterro. In: Folha de São Paulo. São Paulo, 23 de junho de 2002. Mais!

COUTINHO, Afrânio. Introdução à literatura no Brasil. Rio de Janeiro: Civilização Brasileira, 1976. 
COUTO, Rui Ribeiro. Hombre cordial, producto americano. In: HOLANDA, S. B. Raízes do Brasil. Cia das Letras: São Paulo, 2006.

DAMATTA, Roberto. O vício da amizade. In: O Estado de São Paulo. São Paulo, 11 de fevereiro de 2009. Caderno 2.

DEAECTO, Marisa M. Evolução Política do Brasil, de Caio Prado Jr.: itinerário de leitura. In: Revista Espaço Acadêmico. Londrina, março de 2007. N. 70. Ano IV.

DE DECCA, Edgard Salvadori. O homem cordial morreu ou, talvez nunca tenha existido. In: Revista do Instituto Humanitas Unisinos. São Leopoldo, 20 de novembro de 2006. N. 205.

---.. O silêncio dos vencidos. São Paulo: Brasiliense, 1986.

DIAS, Angela Maria. Intelectuais e Alteridade: Reflexões sobre As Raízes e o Labirinto da América Latina de Silviano Santiago. In: Anais das IX Jornadas Andinas de Literatura Latino-americana América Latina: integração e interlocução. Rio de Janeiro: UFF, agosto de 2010.

DIAS, Maria Odila Leite da Silva. Sergio Buarque de Holanda: historiador. São Paulo: Ática, 1985.

---. Raízes do Brasil é um livro atual, que permanece conosco. In: Revista do Instituto Humanitas Unisinos. São Leopoldo, 20 de novembro de 2006. N. 205.

---. Dialogando com Sergio Buarque de Holanda. In: Revista Ciência e Cultura. São Paulo, junho de 2002. V. 54. N.1.

---. Política e sociedade na obra de Sergio Buarque de Holanda. In: CANDIDO, Antonio (Org.). Sergio Buarque de Holanda e o Brasil. São Paulo: Perseu Abramo, 1998.

EULALIO, Alexandre. Antes de tudo, escritor. In: HOLANDA, S. B. Raízes do Brasil. Cia das Letras: São Paulo, 2006. 
EUGÊNIO, João Kennedy. Um horizonte de autenticidade - Sergio Buarque de Holanda: monarquista, modernista, romântico. In: MONTEIRO, Pedro Meira \& EUGÊNIO, João Kennedy. Sergio Buarque de Holanda: perspectivas. Rio de Janeiro: Eduerj, 2006.

---. Um ritmo espontâneo: organicismo em Raízes do Brasil e Caminhos e fronteiras, de Sergio Buarque de Holanda. Tese de Doutorado apresentada ao Departamento de História da Universidade Federal Fluminense. Niterói, 2010.

FAORO, Raymundo. Sergio Buarque de Holanda: analista das instituições brasileiras. In: CANDIDO, Antonio (Org.). Sergio Buarque de Holanda e o Brasil. São Paulo: Perseu Abramo, 1998.

FAUSTO, Boris. A Revolução de 1930: historiografia e história. São Paulo, Brasiliense. 1969.

FINAZZI-AGRÒ, Ettore. A trama e o texto. In: PESAVENTO, Sandra Jatahy (org). Um historiador nas fronteiras: o Brasil de Sergio Buarque de Holanda. Belo Horizonte: Editora da UFMG, 2005.

FORBES, Jorge. O homem cordial e a psicanálise. In: MONTEIRO, Pedro Meira \& EUGÊNIO, João Kennedy. Sergio Buarque de Holanda: perspectivas. Rio de Janeiro: Eduerj, 2006.

FRANZINI, Fábio. A História presente e a História ausente nos volumes da Coleção Documentos Brasileiros (1936-1959). In: XIII Encontro de História da ANPUH-RJ. Rio de Janeiro, agosto 2008.

FREYRE, Gilberto. Casagrande \& senzala. Rio de Janeiro: Record, 2001.

---. Sobrados \& mucambos. São Paulo: Global, 2004.

---. Documentos brasileiros. In: HOLLANDA, Sérgio Buarque de. Raízes do Brasil. Rio de Janeiro: José Olympio, 1936. 
---. Manifesto regionalista. Recife: Massangana, 1996.

GOMES, Angela de Castro. Os intelectuais cariocas, o modernismo e o nacionalismo: o caso Festa. In: Luso-brasilian review. Madison: University of Misconsin, 2004. V. 41. N. 1.

---. O populismo e as Ciências Sociais no país: notas sobre a trajetória de um conceito. In: Revista Tempo. Rio de Janeiro, 1996. V. 1. N. 2.

GUIMARÃES, Eduardo Henrique de Lima Guimarães. A modernidade brasileira reconta as tradições paulistas. In: MONTEIRO, Pedro Meira \& EUGÊNIO, João Kennedy. Sergio Buarque de Holanda: perspectivas. Rio de Janeiro: Eduerj, 2006.

HOLANDA, Maria Amélia Buarque. Apontamentos para a cronologia de Sergio Buarque de Holanda. In: HOLANDA, S. B. Raízes do Brasil. Cia das Letras: São Paulo, 2006.

HOLANDA, S. B. Raízes do Brasil. Cia das Letras: São Paulo, 1999.

---. Raízes do Brasil. Cia das Letras: São Paulo, 2006.

---. Corpo de alma do Brasil: ensaio de psicologia social. In: MONTEIRO, Pedro Meira \& EUGÊNIO, João Kennedy. Sergio Buarque de Holanda: perspectivas. Rio de Janeiro: Eduerj, 2006.

---. Elementos básicos da nacionalidade: o homem. In: MONTEIRO, Pedro Meira \& EUGÊNIO, João Kennedy. Sergio Buarque de Holanda: perspectivas. Rio de Janeiro: Eduerj, 2006.

---. Entrevista à Hispanic american historical review. In: Revista ciência e cultura. Campinas, fevereiro de 1982. V. 62. N. 1.

---. Tentativas de mitologia. São Paulo: Perspectivas, 1979.

KROPF, S. P. Manoel Bomfim e Euclides da Cunha: vozes dissonantes aos horizontes do progresso. In: História, Ciências, Saúde. Manguinhos, mar.-jun. 1996. N. 3. V. 1. 
IGLÉSIAS, Francisco. Um historiador revolucionário. In: --- (org.). Caio Prado Júnior. São Paulo: Ática, 1982.

IUMATTI, Paulo Teixeira. Caio Prado Jr: uma trajetória intelectual. São Paulo: Brasiliense, 2007.

LEENHARDT, Jacques. Frente ao presente do passado: as raízes portuguesas do Brasil. In: PESAVENTO, Sandra Jatahy (org). Um historiador nas fronteiras: o Brasil de Sergio Buarque de Holanda. Belo Horizonte: Editora da UFMG, 2005.

LEITE, Dante Moreira. Cordialidade e aventura. In: ---. O caráter nacional brasileiro: história de uma ideologia. São Paulo: Pioneira, 1983.

LENHARO, Alcir. Sacralização da política. São Paulo: Papirus, 1986.

LEONEL, Maria Célia de Moraes. A revista Estética: contribuição para o estudo do modernismo Brasileiro. Dissertação de Mestrado. São Paulo: USP, 1976.

LEONÍDIO, Aldamir. Uma biografia de um autor esquecido. In: Estudos: Sociedade e Agricultura. Rio de Janeiro, 16 de abril 2001. N. 16.

LEVINO, Rodrigo. Estudo expõe rusgas de Buarque e Freyre. In: Folha de São Paulo. São Paulo, 1 de setembro de 2012. Ilustrada.

LIMA, Elaine. Para além das influências sociológicas. In: Revista Cerrados. Brasília: Universidade de Brasília, 2009. V. 18. N. 28.

LIMA, Jorge de. Poesia completa. Rio de Janeiro: Nova Aguilar, 1997.

LAMOUNIER, Bolivar. O modelo institucional dos anos 30 e a presente crise brasileira. In: Estudos avançados. São Paulo, 1992. V. 6. N. 14. 
LOBATO, Monteiro. Urupês, Cidades mortas, O macaco que se fez homem, Negrinha e $O$ presidente negro: box para adultos. Rio de Janeiro: Editora Globo, 2010.

LIMA, Luiz Costa. José Lins do Rego. In: COUTINHO, Afrânio (Org). A literatura no Brasil. Rio de Janeiro: José Olympio, 1986.

MAIA, João Marcelo Ehlert. A Rússia americana. In: Sociedade e Estado. Brasília, maio/agosto de 2005. V. 20. N. 2.

MARTINS, Luciano. A Revolução de 1930 e seu significado político. In: A Revolução de 1930: seminário internacional. Brasília: Editora da Universidade de Brasília, 1982.

MARTINS, Renato. Encontros: Sergio Buarque de Holanda. Rio de Janeiro: Beco do Azougue, 2009.

MEDEIROS, Leonilde Sérvolo de. Movimentos sociais no campo, lutas por direito e reforma agrária na segunda metade do século XX. In: CARTER, Miguel (Org). Combatendo a desigualdade social: O MST e a reforma agrária no Brasil. São Paulo: Editora UNESP, 2010.

MENDES, Claudinei Magno Magres. O ensaísmo na historiografia brasileira. In: Acta Scientiarum. Maringá, Janeiro/junho de 2012. V. 34. N. 1.

MENDONÇA, Sonia Regina de. As bases do desenvolvimento capitalista dependente: da industrialização restringida à internacionalização. In: LINHARES, Maria Yeda (Org). História geral do Brasil. Rio de Janeiro: Campus, 2000.

MESQUITA, Gustavo Rodrigues. O projeto regionalista de Gilberto Freyre e o Estado Novo: entre a tradição e a modernidade. Dissertação de Mestrado defendida pela Universidade Federal de Goiás. Goiânia, 2012.

MICELLI, Sergio. Intelectuais e classe dirigente no Brasil: 1920-1945. São Paulo: Difel, 1979. 
MONASTERIO, José Ortiz. Sergio Buarque de Holanda: Historia y Literatura, Antología. México: Instituto Mora, 2007.

---. Raízes do Brasil de Sérgio Buarque de Holanda. Un primer acercamiento. In: Anales del Seminario de Historia Intelectual. México: Colégio de Mexico, abril de 2002.

MONTEIRO, Pedro Meira. Buscando América. In: HOLANDA, S. B. Raízes do Brasil. Cia das Letras: São Paulo, 2006.

---. A queda do aventureiro. Campinas: Editora da Unicamp, 1999.

---. Sergio Buarque de Holanda e as palavras. In: Lua Nova: revista de cultura e política. São Paulo, dezembro de 1999b. N. 48.

MORAIS, Fernando. Chatô: o rei do Brasil. São Paulo, Companhia das Letras, 1994.

MOREIRA, Luiza Franco. Meninos, poetas e heróis: aspectos de Cassiano Ricardo do modernismo ao Estado Novo. São Paulo, Edusp, 2001.

MOTA, Lourenço Dantas. Introdução ao Brasil: um banquete no trópico. São Paulo: SENAC, 2000.

MOTA, Carlos Guilherme. Ideologia da cultura brasileira: 1933-1974. São Paulo: Editora 34, 2008.

---. A ideia de Revolução no Brasil e outras ideias. Rio de Janeiro: Globo, 2008b.

NASCIMENTO, Evandro. O entre-lugar da leitura. In: Revista de Letras. São Paulo: UNESP, julho/dezembro de 2006. V. 46. N. 2.

NETTO, Domingo Francilli. A lei, ora, a lei. In: Correio braziliense. Brasília, 27 de julho de 2003. 
NEVES, Cleiton Ricardo das. Discutindo identidades: Manoel Bomfim e o discruso identitário latino-americano. In: I Seminário de Pesquisa de Pós-gradução em História. Goiania: Universidade Federal de Goiás e Pontifícia Universidade Católica de Goiás, setembro de 2008.

NICODEMO, Thiago Lima. O cânone da impermanência. In: Revista do Instituto de Estudos Brasileiros. São Paulo, setembro de 2009. N. 49.

NICOLAU, Jairo Marconi. História do voto no Brasil. Rio de Janeiro: Jorge Zahar, 2002.

OLIVEIRA, Francisco de. Jeitinho e jeitão: uma tentativa de interpretação do caráter brasileiro. In: Piauí. São Paulo, outubro de 2012. N. 73.

OLIVEIRA, Lucia Lippi. Gilberto Freyre e a Valorização da Província. In: Revista Sociedade e Estado. Brasília, janeiro/abril de 2011. V. 26. N. 1.

---. A questão nacional na primeira república. São Paulo: Brasiliense, 1990.

---. Elite intelectual e debate político nos anos 30: uma bibliografia comentada da Revolução de 1930. Rio de Janeiro: Fundação Getulio Vargas, 1980.

PAIVA, Geraldo José de. Dante Moreira Leite: um pioneiro da psicologia social no Brasil. In: Revista Psicologia USP. São Paulo, 2000. V. 11. N. 2.

PÉCAULT, Daniel. Os intelectuais e a política no Brasil: entre o povo e a nação. São Paulo: Ática, 1990.

PIVA, Luiz Guilherme Piva. Ladrilhadores e semeadores: a modernização brasileira no pensamento político de Oliveira Viana, Sergio Buarque de Holanda, Azevedo Amaral e Nestor Duarte. São Paulo: Editora 34, 2000.

---. Uma visão cada vez mais enraizada do Brasil. In: O Estado de São Paulo. São Paulo, 2 de fevereiro de 2001. Caderno 2. 
PRADO, Antonio Arnoni. No roteiro de Raízes. In: In: HOLANDA, S. B. Raízes do Brasil. São Paulo: Cia das Letras, 2006.

---. O espírito e a letra. São Paulo: Cia das Letras, 2006.

PRADO, Maria Lígia. A democracia ilustrada: o Partido Democrático de São Paulo. São Paulo: Ática, 1986.

PRADO, Paulo. Retrato do Brasil. São Paulo: Cia das Letras, 2001.

PRADO JUNIOR, Caio. Evolução política do Brasil: colônia e império. São Paulo: Brasiliense, 2007.

RAMÍREZ, Paulo Nicoli. Sergio Buarque de Holanda e a dialética da cordialidade. São Paulo: EDUC, 2011.

RAMOS, Graciliano. 120 anos: Box - Caetés, São Bernardo, Vidas secas e Angústia. São Paulo: Record, 2012.

REGO, José Lins do. O ciclo da cana: box. Rio de Janeiro: José Olympio, 2012.

REIS, José Carlos. Sergio Buarque de Holanda: a superação das raízes ibéricas. In: ---. Identidades do Brasil: de Varnhagen a FHC. Rio de Janeiro: FGV, 2000.

---. Caio Prado Jr e a revolução brasileira. In: Revista Brasileira de História. São Paulo: Associação Nacional de História, setembro de 1999. V. 19. N. 37.

RIBEIRO, Darcy. Manoel Bomfim: antropólogo. In: BOMFIM, Manuel. América Latina: males de origem. Rio de Janeiro: Topbooks, 2005.

---. Uma introdução a Casa-grande \& senzala. In: FREYRE, Gilberto. Casagrande \& senzala. Rio de Janeiro: Record, 2001. 
RIBEIRO, Marcus Venicio. Paixão radical pelo Brasil. In: BOMFIM, Manuel. Brasil nação. Rio de Janeiro: Record, 1998.

RICARDO, Cassiano. Sobre o homem cordial. In: HOLANDA, S. B. Raízes do Brasil. Cia das Letras: São Paulo, 2006.

RIO, João do. A alma encantadora das ruas. São Paulo: Cia das Letras, 2008.

ROCHA, Gilmar. Nação, tristeza e exotismo no Brasil da Belle Époque. In: Varia História. Belo Horizonte, Janeiro de 2001. N. 24.

ROCHA, João Cezar de Castro. Nenhum Brasil existe. In: Folha de São Paulo. São Paulo, 23 de janeiro de 2000 .

---. O exílio como eixo: bem sucedidos e desterrados - ou Por uma edição crítica de Raízes do Brasil. In: MONTEIRO, Pedro Meira \& EUGÊNIO, João Kennedy. Sergio Buarque de Holanda: perspectivas. Rio de Janeiro: Eduerj, 2006.

SALIBA, Elias Thomé. Uns poucos modernos: semana de 22. In: Carta Capital. São Paulo: Abril, fevereiro de 2012.

---. Raízes da melancolia. In: Carta Capital. São Paulo: Abril, junho de 2011.

SALLUM JR, Brasílio. Sergio Buarque de Holanda. In: MOTA, Lourenço Dantas. Introdução ao Brasil: um banquete no trópico. São Paulo: SENAC, 2000.

SANTIAGO, Silviano. Mário, Oswald e Carlos, intérpretes do Brasil. In: Revista Alceu. Rio de Janeiro: janeiro/junho de PUC, 2005. V. 5. N. 10.

SANTOS, Analice Alves Marinho. A formação da nação brasileira segundo Manoel Bomfim e Silvio Romero: debates acerca dos meios e caminhos para a civilização. In: VI Simpósio Nacional de Estado e Poder: Cultura. Aracaju: Núcleo de Pesquisa Estado e Poder da Universidade Federal Fluminense e Universidade Federal de Sergipe, outubro de 2010. 
SANTOS, Nelson Pereira. Raízes do Brasil, uma cinebiografia de Sérgio Buarque de Holanda. Rio de Janeiro: Videofilmes, 2003.

SANTOS, Robson dos. Cultura e tradição em Gilberto Freyre: esboço de interpretação do Manifesto Regionalista. In: Revista Sociedade e Cultura. Goiania, Universidade Federal de Goiás, 2011. V. 14. N. 2.

SANTOS, Wanderley Guilherme. Intelectuais e propósitos: a riqueza que nada compra. In: Revista em pauta: revista da Faculdade de Serviço Social da UERJ. Rio de Janeiro, 2009. N. 22.

SCHWARCZ, Lilia Moritz. Sergio Buarque de Holanda e essa tal de cordialidade. In: Revista Ide: psicanálise e cultura. São Paulo, 2008. V. 31. N. 46.

---. História do Brasil nação: 1808-2010. Rio de Janeiro: Objetiva, 2012. V. 3.

SCHWARTZMAN, Simon. Gustavo Capanema e a educação brasileira: uma interpretação. In: Revista Brasileira de Estudos Pedagógicos. Rio de Janeiro, 1944. V. 1. N. 1.

SEVCENKO, Nicolau. Literatura como missão: tensões sociais e criação cultural na Primeira República. São Paulo: Cia das Letras, 2003.

SILVA, Rafael Pereira da. Conversas com Sergio Buarque de Holanda. In: Revista História da historiografia. Ouro Preto, abril de 2012. N. 8.

SODRÉ, Nelson Werneck. Introdução à revolução brasileira. São Paulo: Editora Civilização Brasileira, 1967.

SOUZA, Laura de Mello e Souza. A revolução subterrânea. In: Folha de São Paulo. São Paulo, 8 de agosto de 2004. Mais!

STÉDILE, João Pedro. O MST e a questão agrária. In: Estudos avançados. São Paulo: USP, 1997. V. 11. N. 31. 
TANNO, Janete Leiko. Cartas de presos políticos e de seus familiares: violência e atuação feminina no governo Vargas: 1930-1945. In: Revista patrimônio e memória. São Paulo: UNESP/ FCLAs/ CEDAP, 2005. V.1. N.1. 2005.

TELES, Gilberto Mendonça Teles. Vanguarda europeia e modernismo brasileiro: apresentação e crítica dos principais manifestos vanguardistas. Petrópolis, Vozes, 2009.

VECCHI, Roberto. Atlas intersticial do tempo do fim: Nossa revolução. In: PESAVENTO, Sandra Jatahy (org). Um historiador nas fronteiras: o Brasil de Sergio Buarque de Holanda. Belo Horizonte: Editora da UFMG, 2005.

VELOSO, Mariza \& MADEIRA, Angélica. Sergio Buarque de Holanda: raízes e rizomas do Brasil. In: ---. Leituras brasileiras: itinerários no pensamento social e na literatura. Rio de Janeiro: Paz e Terra, 2000.

VELlOSO, Mônica Pimenta. O mito da originalidade brasileira: a trajetória intelectual de Cassiano Ricardo dos anos 20 ao Estado Novo. Dissertação de mestrado. Rio de Janeiro: PUC, 1983.

VIANA, Luiz Werneck. A revolução passiva: iberismo e americanismo no Brasil. Rio de Janeiro, Revan, 2004.

---. Liberalismo e sindicato no Brasil. São Paulo: Paz e Terra, 1976.

VICTORIANO, Márcia R. A questão nacional em Caio Prado Jr: uma interpretação original do Brasil. São Paulo: Edições Pulsar, 2001.

WAIZBORT, Leopoldo \& GOLDFEDER, André. Sobre os “tipos” em Raízes do Brasil. In: Revista do IEB. São Paulo: março/setembro de 2009. N. 49.

WAIZBORT, Leopoldo. O mal-entendido da democracia: Sergio Buarque de Holanda, Raízes do Brasil, 1936. In: Revista Brasileira de Ciências Sociais. São Paulo, junho de 2011. V. 26. N. 76. 
WALDMAN, Thaís Chang. Paulo Prado: entre espaços e traduções. In: II Seminário Nacional de Sociologia e Política. Curitiba, setembro de 2010.

---. Espaços de Paulo Prado: tradição e modernismo. In: Revista Artelogie. Paris, 2011. N. 1. V. 1.

WEFFORT, Francisco. O populismo na política brasileira. São Paulo: Paz e Terra, 1989.

WEGNER, Robert. Um ensaio sobre o passado e o futuro. In: HOLANDA, S. B. Raízes do Brasil. Cia das Letras: São Paulo, 2006.

---. Análises recentes da obra de Sergio Buarque. In: CALDEIRA, João Ricardo de Castro. Perfis buarqueanos. São Paulo: Memorial, 2005. 


\section{México e mexicanos}

ADIB, Victor. La tercera edición de El perfil... In: PALACIOS, Adela. Nuestro Samuel Ramos. México: MCMLX, 1960.

AGUILAR CAMÍN, Héctor \& MEYER, Lorenzo. À sombra de Revolução mexicana. São Paulo: EDUSP, 2000.

AGUILAR MONTEVERDE, Alonso. Narciso Bassols: pensamiento y acción. In: Problemas del desarrollo: Revista latinoamericana de economía. México, 1995. V. 26. N. 103.

ALCUBIERRE MOYA, Beatriz \& RAMÍREZ GARRIDO, Jaime. Martín Luis Guzman: a la sombra de la Revolución. In: Revista Nexos. México, diciembre de 2011.

ALMADA BAY, Ignacio. ¿Cuál triángulo sonorense? In: Revista Región y sociedad. México, 2008. V. XX. N. 41.

---. El discreto encanto de las mitades de Plutarco Elías Calles. In: Revista Historia Mexicana. México, 2009. V. LVIII. N. 3.

---. De regidores porfiristas a presidentes da república no período revolucionario: explorando el ascenso y la caída del sonorismo. In: Revista Historia Mexicana. México, 2010. V. LX. n. 2.

---. El molde que fraguó a Plutarco. In: Revista relatos y historias de México. México, abril de 2012. V. IV. N. 44.

ARREOLA CORTES, Raúl. Historia de la Universidad Michoacana. Morelia: UMSNH, 1984.

---. Samuel Ramos: la pasión por la cultura. Morelia: UMSNH, 1997.

ARREOLA MARTÍNEZ, Betzabé. Vasconcelos: el caudillo cultural de la nación. In: Casa del tiempo. México, noviembre de 2009. V. 3. N. 25. 
ARISTEGUI F., Carmen. Cien años. In: El Norte. Monterrey, 19 de noviembre de 2010. p. 9A.

AZUELA, Mariano. Los de abajo. México: FCE, 2000.

---. Algo sobre Novela Mexicana Contemporánea. In: VASCONCELOS, José. Ulises criollo. México: Scipione Cultural, 2000.

BAILEY, David. El revisionismo en la historiografía reciente de la revolución mexicana. In: Revista ¡Siempre! México, mayo de 1979. N. 895.

BAR-LEWAW, Itzhak. La revista Timón y la colaboración nazi de José Vasconcelos. In: Actas del cuarto Congreso Internacional de Hispanistas. Salamanca, 1982. V. 1.

BARTRA, Roger. La jaula de la melancolía: identidad y metamorfosis del mexicano. México: Grijalbo, 1987.

BETANCOURT CID, Carlos. Revolución: amor y odio en el Ateneo de la Juventud. In: Expedientes Digitales INEHRM. México, 2010. Capturado em:

http://www.inehrm.gob.mx/Portal/PtMain.php?pagina=exp-ateneo-de-la-juventud

BORJOQUEZ, Juan de Dios. Forjadores de la Revolución Mexicana. México: IMEHRM, 1960.

BORSÓ, Vittoria. La capital - contemporánea de todos los tiempos: Salvador Novo. In: DAUS, Ronald (Org). Internationales Colloquium über Lateinamerikanische, Afrikanische und Asiatische Metropolen. Berlin, 1990.

BRITTON, John A. Moisés Sáenz: nacionalista mexicano. In: Historia mexicana: México, Julio/septiembre de 1972. V. 22. N. 1 (85).

BRUSHWOOD, John S. Las bases del vanguardismo en Xavier Icaza. In: Texto Crítico. Veracruz: enero-diciembre de 1982. N. 24-25. 
CACHIE-PINEDA, Maryse. El Ulises criollo, 1935: ¿Una nueva historia mexicana revisitada? In: VASCONCELOS, José. Ulises criollo. México: Scipione Cultural, 2000.

CAMÍN, Héctor Aguilar; MEYER, Lorenzo. A sombra da Revolução Mexicana. São Paulo: Edusp, 2000.

CAMÍN, Héctor Aguilar. Ovación, denostación y prólogo. In.: GILLY, Adolfo (et. All). Interpretaciones de la Revolución Mexicana. México: Universidad Nacional Autónoma de México \& Editorial Nueva Imagen, 1979.

CARBALLO, Emmanuel. Una sabia naturalidade: entrevista com Martín Luis Guzman (1958). In: La jornada semanal. México, 17 de junio de 2001.

CARMONA, Fernando Inés. Confrontó Heriberto Jara el poder de Plutarco Elías Calles y Álvaro Obregón. In: La jornada. Veracruz, noviembre de 2010.

CASO, Antonio. Obras completas. México: UNAM, 1976.

CASO, Antonio; REYES, Alfonso; UREÑA, Pedro Henriquez; GONZÁLEZ PEÑA, Carlos; ESCOFET, José; VASCONCELOS, José. Conferéncias del Ateneo de la Juventud. México: UNAM, 2000.

CASTRO, Pedro. A la sombra del caudillo: vida y muerte del general Francisco R. Serrano. México: Plaza Janés, 2005.

---. Álvaro Obregon. In: Polis: investigación y análisis psicosocial. México, 2003. V. 3.

CUESTA, Jorge. Obras reunidas. México: FCE, 2004.

CORDOBA, Arnaldo. Ideologia de la Revolución Mexicana: la formación del nuevo régimen. México: Era, 1980.

CORRÊA, Ana Maria M. A Revolução Mexicana 1910-1917. São Paulo: Brasiliense, 1983. 
CURRIEL DEFOSSÉ, Fernando. Vasconcelos: forzado relevo ateneísta. In: Estudios de Historia Moderna y Contemporánea de México. México, 1998. V. 18

DEL VALLE, Agustín Basave Fernández. Samuel Ramos: trayectoria filosófica. México: CEH de la UNL, 1965.

DÍAS ARCIENIEGA, Víctor. Querella por la cultura "revolucionária" (1925). México: FCE, 2010.

DÍAZ, Carlos Eduardo. Mario Moreno Cantinflas: el peladito mexicano. In: Revista contacto. México, agosto de 2011.

DOMÍNGUEZ MICHAEL, Christopher. José Vasconcelos, padre de los bastardos. In: VASCONCELOS, José. Ulises criollo. México: Scipione Cultural, 2000.

---. Prologo. In: VASCONCELOS, José. Obra seleta. Caracas: Biblioteca Ayacucho, 1992.

DURÁN, Manuel. 'Contemporáneos': ¿Grupo, promoción, generación, conspiración? In: Revista Iberoamericana. Pittsburgh, enero/junio de 1982. V. 48. N. 118.

ESCALANTE, Evodio Escalante. Espectralidad y eficacia de la Revolución en Dama de corazones de Xavier Villaurrutia. In: Signos Literarios. México, enero/junio de 2007. V. 5. N. 1.

ESTRELLA GONZÁLEZ, Alejandro. Antonio Caso y las redes filosóficas mexicanas: sociología de la creatividad intelectual. In: Revista Mexicana de Sociología. México, abriljunio de 2010. V. 72. N. 2.

FERNANDES, Luis Estevam \& BARBOSA, Fernanda Bastos. Pacificar a história: passado, presente e futuro nas formas de pensar a política mexicana na transição do século XIX ao XX. In: História da Historiografia. Ouro Preto, novembro/dezembro de 2011. N. 27. 
FREUD, Sigmund. O mal estar na civilização. In: ---. Obras psicológicas completas de Sigmundo Freud. Rio de Janeiro: Editora Imago, 2006. V. XXI.

FUENTES, Carlos. Centenario. In: Reforma. México 22 de noviembre de 2010. p. 23A.

GALLO, Miguel Angel. Del carrancismo al cardenismo. México: Ediciones Quinto Sol, 1989.

GAMIO, Manuel. Forjando pátria: pró-nacionalismo. México: Porrúa, 1916.

GARCÍADIEGO DANTAN, Javier. La revolución mexicana: crónicas, documentos, planes y testimonios. México: UNAM, 2005.

---. Tres asedios a Vasconcelos. In: VASCONCELOS, José. Ulises criollo. México: Scipione Cultural, 2000.

GARCIADIEGO DANTAN, Javier. La campaña de 1929: el mito del fraude. In: Relatos e historias en México. México: Editorial Raíces, agosto 2009. V. I. N. 12.

GARÍA GUTIÉRREZ, Rosa. Jóvenes y maestros: los contemporáneos bajo la tutela de José Vasconcelos, Pedro Henriquez Ureña y Alfonso Reyes. In: Anales de Literatura hispanoamericana. México, 1998. N. 27.

GILLINGHAM, Paul. Las arenas movedizas de la identidad nacional. In: Este país: tendencias y opiniones. México, 17 de abril de 2009. N. 217.

GONZALEZ, Ángeles. Manuel Gamio: el amor de un mexicano. In: La jornada semanal. Ciudad de México, 26 de agosto de 2012. N. 912.

GOROSTIZA, Celestino. Galeria de poetas nuevos de México. In: DURÁN, Manuel. Antología de la revista Contemporáneos. México: FCE, 1973. 
GUERRA MANZO, Enrique. Pensar la Revolución Mexicana: tres horizontes de interpretación. In: Secuencia. México, enero/abril de 2006. N. 6. V. 1.

GUERRERO, Francisco Javier. Moisés Sáenz: el precursor olvidado. In: Revista Nueva Antropología. México, julio 1975. V. 1. N. 1.

GUERRERO FLORES, David. Samuel Ramos: en búsqueda de su saber filosófico. In: Expedientes Digitales INEHRM. México, 2010. Capturado em:

http://www.inehrm.gob.mx/Portal/PtMain.php?pagina=exp-samue-ramos

GUY, Alain. Samuel Ramos y el humanismo filosófico de México. In: Dianóia. México, 1960. V. 6. N. 6.

GUZMÁN, Martín Luis. La sombra del caudillo. México: Sudamericana, 2002.

---. El águila y la serpiente. México: Anahuac, 1941.

HERNÁNDEZ LUNA, Juan. Biografía de Samuel Ramos. In: RAMOS, S. Obras completas. México: UNAM, 1990. N. II.

---. Samuel Ramos: su filosofar sobre lo mexicano. México: UNAM, 1956.

---. Samuel Ramos: etapas de su formación espiritual. Morelia: UMSNH, 1982.

HERNÁNDEZ PRADO, José. El liberalismo de Caso. In: Revista sociológica. México, mayo/agosto de 2000. V. 15. N. 43.

HERNÁNDEZ RODRÍGUEZ, Rafael. Whose sweaty men are they? - Avant-garde and revolution in Mexico. In: Ciberletras: Revista de crítica literaria y de cultura. NY: Dept. of Lenguages and Literatures of Lahman College, 2002. N. 8.

HERNÁNDEZ URÍA, Víctor Manuel. Antonio Caso y su concepto del hombre. In: SALADINO GARCÍA, Alberto (Org) Humanismo mexicano del siglo XX. Toluca: Universidad Autónoma del Estado de México, 2004. T. I. 
HURTADO, Guillermo. Reflexiones filosóficas sobre la crisis de México. In: Revista de la Universidad de México. México, diciembre de 2009. N. 70.

---. El búho y la serpiente: Ensayos sobre la filosofía en México en el siglo XX. UNAM: México, 2007.

--- (Org). Archivo Samuel Ramos. México: IIF/UNAM, 2005.

JENVRIN, Raphaële Plu. La "Mexicanidad" como soporte para la representación de la institución presidencial en el México post-revolucionario: ¿Hacia qué definición de la Nación? In: HISTOIRE(S) de l'Amérique latine. Paris, 2005. V. 1.

KATZ, Friedrich. O México: o Porfiriato. In: BETHELL, Leslie. Historia da América Latina: de 1870 a 1930. São Paulo: EDUSP, 2002.

KNIGHT, Alan. La revolución mexicana: ¿burguesa, nacionalista, o simplemente "gran rebelión"? In: Cuadernos Políticos. México, octubre-diciembre, de 1986. n. 48.

---. Frank Tannembaum. In: Estudios de Historia Moderna y Contemporánea de México. México: UNAM, 1999. v. 19.

KRAUZE, Enrique. Los dos Meyer. In: Letras libres. Ciudad de México, diciembre de 2011.

---. Si no hubiera muerto. In: EI Norte. Monterrey, 14 de noviembre de 2010. p. 8A.b

---. Nueva crisis de México. In: EI Norte. Monterrey, 7 de febrero 2010. c.

---. Han fallado los hombres. In: EI Norte. Monterrey, 21 de marzo de 2010.

KRAUZE, Enrique \& KOLTENIUK, Rosa. La filosofía de Antonio Caso. México: UNAM, 1990. 
KURZ, Andrea. La importancia de filosofía y cultura alemanas en la revista Contemporáneos. In: Literatura mexicana. México, 2008. V. 19. N. 1.

LARROYO, Francisco. Samuel Ramos: etapas de su evolución filosófica. In: RAMOS, S. Obras completas. México: UNAM, 1975. V. I.

LAZARÍN MIRANDA, Federico. José Vasconcelos: apóstol de la educación. In: Casa del tiempo. México, noviembre de 2009. V. 3. N. 25.

LEON DE PALACIOS, Ana Ma. Plutarco Elías Calles. México: INAP, 1975.

LÓPEZ VELARDE, Ramón. La suave patria y otros poemas. México: Fondo de Cultura Económica, 1987.

MAGALlO ANAYA, Mario. Ramos y su idea de cultura en México. In: Temas de ciencia y tecnología. México, septiembre/diciembre de 2008. V. 11. N. 33.

MARTÍNEZ, Abel Juárez. Gente mexicana de Xavier Icaza: un prototipo de literatura regional. In: La Palabra y el Hombre Veracruz, julio-septiembre 1996. N. 99.

MATUTE, Álvaro. Orígenes del revisionismo historiográfico de la revolución mexicana. In: Signos históricos. Ciudad de México, junio de 2000. V. II. N. 3.

---. Aproximaciones a la historiografía de la Revolución Mexicana. México: UNAM-IIH, 2005 .

---. Héctor Aguilar Camín - La frontera nómada. In: Estudios de Historia Moderna y Contemporánea de México. México, 1979. V. 7. p. 243-245.

MEDIN, Tzvi. El minimato presidencial: historia política del maximato. México: Era, 1982. 
---. La mexicanidad política y filosófica en el sexenio de Miguel Alemán. 1946-1952. In: Estudios interdisciplinarios de América Latina y el Caribe. Tel Aviv, junio de 1990. V. 1. N. 1.

MESQUITA, Ivo. Manifestos e declarações - 1921 a 1950. In: BELLUZZO, Ana Maria de Moraes. Modernidade: vanguardas artísticas na América Latina. São Paulo: Memorial, 1990.

MEYER, Jean. Alan Knight: La Revolución Mexicana. In: Política y gobierno. México, primer semestre de 1997. v. 4. n. 1. p. 191-195.

---. México: revolução e reconstrução. In: BETHELL, Leslie. Historia da América Latina: de 1870 a 1930. São Paulo: EDUSP, 2002.

MEYER, Lorenzo. Cien años no son casi nada. In: El Norte. Monterrey, 18 de noviembre 2010.

---. Revolución y sistema: México entre 1910-1940. México: SEP, 1987.

MIJANGOS DÍAZ, Eduardo. La revolución mexicana y los nuevos enfoques historiográficos; entrevista con Gloria Villegas. In: Tzintzun: revista de estudios históricos. Morelia, diciembre de 1991. N. 14.

MIZZI, Philippe Schaffhauser. El proyecto Carapan de Moisés Sáenz: una experiencia educativa entre indigenismo y desarrollo rural. In: Anales del VI Congreso Internacional del CEISAL. Toulouse, junio/julio de 2010.

MONSIVAIS, Carlos. Escenas de pudor y liviandad. México: Debolsillo, 2004.

---. Las tradiciones de la imagen: notas sobre poesía mexicana. México, Editorial Planeta Mexicana, 2002.

---. La aparición del subsuelo: sobre la cultura de la Revolución Mexicana. In: História. México, enero/junio de 1985. V. 8. N. 9. 
MONTEMAYOR, Carlos. Liminar. In: GUZMÁN, Marín Luis. La sombra del caudillo. México: ALLCA, 2002.

MONTES DE OCA NAVAS, Elvira. La disputa por la educación socialista em México durante el gobierno cardenista. In: Educede: artículos arbitrados. Bogotá: Universidad de Los Andes, julio/septiembre de 2008. V. 12. N. 42.

MORA, Francisco Javier. El estridentismo mexicano: señales de una revoluloción estética y política. In: Anales de Literatura Hispanoamericana. Madrid, 2000. N. 29.

MORAES, Rafael Vicente de. A Revolução Mexicana na perspectiva de Frank Tannembaum e Jesus Herzog: notas de leitura. In: Anais das Jornadas Bolivarianas: nações e nacionalismos na América Latina. Florianópolis: Instituto de Estudos Latinoamericanos da Universidade Federal de Santa Catarina, 2008.

MORENO, Rafael. Estudio introdutório. RAMOS, Samuel. Hacia un nuevo humanismo: programa de una antropología filosófica. México: FCE, 1997.

MUÑOZ, Ignacio. Verdad y mito de la Revolución Mexicana: retratada por un protagonista. México: Ediciones Populares, 1960.

MUÑOZ ROSALES, Victórico. Samuel Ramos. In: DUSSEL, E. \&, MENDIETA, E., \& BOHÓRQUEZ, C. (Org). Pensamiento filosófico latinoamericano, del Caribe y latino, México: Stony Brooky, 2008.

---. Samuel Ramos como paradigma de la Filosofía mexicana. In: Anales del Seminario 70 años de la apertura de la asignatura de Filosofía en México por Samuel Ramos. México, agosto de 2011.

MÚRGIA, Mario. La extemporánea contemporaneidad de Salvar Novo. In: Iberoamérica global. Julio de 2008. V. 1. N. 3.

NOVO, Salvador. Poesia. México: FCE, 1971. 
OCAMPO LOPES, Javier. José Vasconcelos y la educación mexicana. In: Rhela: Revista de Historia de la Educación Latinoamericana. Bogotá, 2005. V. 7.

ONTIVEROS, José Luis. Rubén Salazar Mallén: proscrito de los contemporáneos. In: La palabra y el hombre. Veracruz, enero/junio de 1985. N. 53.

PALACIOS, Adela. Nuestro Samuel Ramos. México: MCMLX, 1960.

PALACIOS, Guillermo. Intimidades, conflitos e reconciliações. São Paulo: EDUSP, 2008.

PAVANI, Rafael. A Revolução Mexicana e as tentativas de legitimzação do poder nos discursos presidenciais de Lazaro Cardenas (1934-1940). Dissertação de Mestrado apresentada ao Programa de Pós-Graduação em História da Unicamp. Campinas, 2009.

PARRA AGUILAR, Manuel. Tradición y ruptura en la literatura mexicana del siglo XX. In: El coloquio de los perros: Revista de Literatura y Cultura. México, otoño de 2007. N. 18.

PATIÑO PALAFOX, Luis. Problemas históricos y políticos en El perfil del hombre y la cultura en México de Samuel Ramos. In: Anales del Seminario 70 años de la apertura de la asignatura de Filosofía en México por Samuel Ramos. México, agosto de 2011.

PAZ, Octavio. El laberinto de la soledad. México: Fondo de Cultura Económica, 1950.

---. O labirinto da solidão. São Paulo: Paz e Terra, 2006.

PÉREZ ROMERO, Francisco Javier. El sentimiento de inferioridad del mexicano y la posibilidad de una cultura mexicana en El perfil del hombre y la cultura en México. Tesis presentada para obtener el título de Licenciado en Filosofía por la Universidad Autónoma Metropolitana de Iztapalapa. México, outubro de 2004.

PRAMPOLINI, Ida Rodríguez. Antecedentes del surrealismo em México. BELLUZZO, Ana Maria de Moraes. Modernidade: vanguardas artísticas na América Latina. São Paulo: Memorial, 1990. 
QUINTANILlA, Susana. A salto de Mata: Martin Luis Guzman en la Revolución Mexicana. México: Tusquets Editores, 2009.

---. El águila y la serpiente de Martín Luis Guzman. In: Revista Letras Libres. México, abril de 2010.

PÉREZ DE LA CRUZ, Rosa Elena. José Vasconcelos. In: ROVIRA GASPAR, M ${ }^{\mathrm{a}}$ del Carmen. Una aproximación a la historia de las ideas filosóficas en México: siglo XIX y principios del XX. Queretaro: UAQ, 2011. T. II.

PURNELL, Jennie. Popular moviments and State formation in Revolutionary Mexico: the agraristas and cristeros of Michoacan. Durham: Duke University Press, 1999.

RAMÍREZ SÁNCHEZ, Maurício César. Calles en Alemania. In: Cronicas. México, s/d. N. $10-11$.

RAMOS, Samuel. El perfil del hombre y la cultura en México. México: Espasa-Calpe, 1996.

---. Prólogo. In: TORRES OROZCO, José. Los datos de la filosofía. México: Jenaro de la Colina, 1970. T. II.

REED, John. México insurgente. São Paulo: Boitempo, 2010.

REYES, Aurelio de los. Historia de la vida cotidiana en México. México: FCE, 2006. V. 1 e 2. T. V.

REYES, Raúl Cardiel. Prólogo. In: RAMOS, S. Obras completas. México: UNAM, 1991. V. III.

RIUS. La revolucioncita mexicana. Mexico: Grijalbo, 1997. 
RODRÍGUEZ, Martha. Biografía de Samuel Ramos. In: PALACIOS, Adela. Nuestro Samuel Ramos. México: MCMLX, 1960.

ROVIRA GASPAR, $\mathrm{M}^{\mathrm{a}}$ del Carmen. Una aproximación a la historia de las ideas filosóficas en México: siglo XIX y principios del XX. Queretaro: UAQ, 2011. T. II.

ROSADO, Juan Antonio. Tres novelas mexicanas del siglo XIX. In: Contribuciones desde Coatepec. Toluca, enero/junio de 2002. N. 2.

SALAZAR MALlÉN, Rubén. Ramos. In: PALACIOS, Adela. Nuestro Samuel Ramos. México: MCMLX, 1960.

SÁNCHEZ SUSARREY, Jaime. Cien años. In: El Norte. Monterrey, 20 de noviembre de 2010. p. 10A.

SÁNCHEZ, Fernando Fabio. Contemporáneos y estridentistas ante la identidad y el arte nacionales en el México post-revolucionário de 1921-1934. In: Revista de crítica literaria latinoamericana. Lima, segundo semestre de 2007. V. 33. N. 66.

SANTOS JR, Valdir Donizete dos. Civilização e alimentação: as origens alimentares do fracasso hispano-americano na obra de Francisco Bulnes. In: Anais do $\mathbf{X}$ Encontro Internacional da ANPHLAC. São Paulo, Julho de 2012.

SARMIENTO, Sergio. La bola. In: EI Norte. Monterrey, 19 de noviembre de 2010. p. 8A.

SCALANTE, Evodio. Elevación y caída del Estridentismo. México: CONACULTA, 2002. p. 12.

SCHÁVELZON, Daniel. Una odisea continental: las piernas de Cuauhtémoc que perdieron los pies en Tula. In: Arqueología mexicana. México: enero/febrero de 2012. V. 19. N. 113.

SEGOVIA, Rafael. El nacionalismo mexicano: programas políticos revolucionários de 1929 a 1964. In: Lecturas de política mexicana. Ciudad de México: COLMEX, 1981. N. 40. 
SHERIDAN, Guillermo. Los contemporáneos ayer. México: FCE, 1985.

SOLARES, Ignacio. El jefe máximo. México: Alfaguara, 2011.

SOLÍS, Ricardo. Álvaro Matute: le reeditan compilación de ensayos sobre la Revolución Mexicana. In: La jornada. Jalisco, 8 de mayo de 2010.

SOUSA, Fábio da Silva. Clio e Mnemosine: a disputa pela História e pela(s) memória(s) da Revolução Mexicana. In: Outros tempos. São Luís do Maranhão, julho de 2009. V. 6. .n. 7.

STANTON, Anthony. Octavio Paz y los contemporáneos: la historia de una relación. In: Actas del X Congreso de la Asociación Internacional de Hispanistas. Barcelona, 21-26 de agosto de 1989. V. 4.

TANNENBAUM, Frank. The Mexican Agrarian Revolution. New York: The Macmillan Company, 1929.

TENORIO, Mauricio. Um Cuauhtémoc carioca: comemorando o centenário da independência do Brasil e a raça cósmica. In: Estudos Históricos. Rio de Janeiro, 1994. V. 7. n. 14.

TORRES AGUILAR, Morelos. Cultura y revolución: La Universidad Popular Mexicana (Ciudad de México, 1912-1920). México: UNAM, 2010a.

---. La Universidad Popular Mexicana y la revolución intelectual de México durante el primer cuarto del siglo XX. In: Anales de la XIII Reunión de historiadores de México. Estados Unidos y Canadá. Santiago de Querétaro, octubre de 2010b.

URANGA, Emilio. Juan de Cárdenas: sus amigos y sus enemigos. In: Historia mexicana. México, abril/junio de 1967. V. 16. N. 4 (64).

UREÑA, Pedro Henríquez. Estudios mexicanos. México: FCE, 1984.

---. Utopia de América. Caracas: Biblioteca Ayacucho, s/d. 
VASCONCELOS, José. ¿Qué es la revolución? México: Botas, 1937.

---. La raza cósmica. México: Colleción Austral, 1948.

---. Ulises criollo. México: Scipione Cultural, 2000.

---. Indología. Barcelona: Agencia Mundial de Librería, s/d.

---. Obra seleta. Caracas: Biblioteca Ayacucho, 1992.

VÁZQUES, Abraham. Fue Cristiada choque utópico. In: El Norte. Monterrey, 26 de agosto de 2010. Sección Vida. p. 11.

VILLEGAS, Abelardo. La filosofía de lo mexicano. México: FCE, 1960.

WOMACK, John. A Revolução Mexicana. In: BETHELL, Leslie. Historia da América Latina: de 1870 a 1930. São Paulo: EDUSP, 2002.

ZAGAL, Hector. Ramos tenía razón. In: Letras libres. México, mayo de 2010.

ZAÏTZEFF, Serge I. Canas de Jaime Torres Bodet a Genaro Estrada. In: Anales de Literatura Hispanoamericana. Madrid, 1992. V. 21.

ZEA, Leopoldo. Conciencia y posibilidad del mexicano. México: Porrúa, 1952.

---. Vasconcelos y Ramos en la Filosofía Mexicana. In: Dianóia. México, 1960. V. 6 n. 6. 